Prepared in cooperation with the U.S. Fish and Wild life Service

Mercury and Selenium Contamination in Waterbird
Risk to Avian Reproduction at Great Salt Lake, Utah

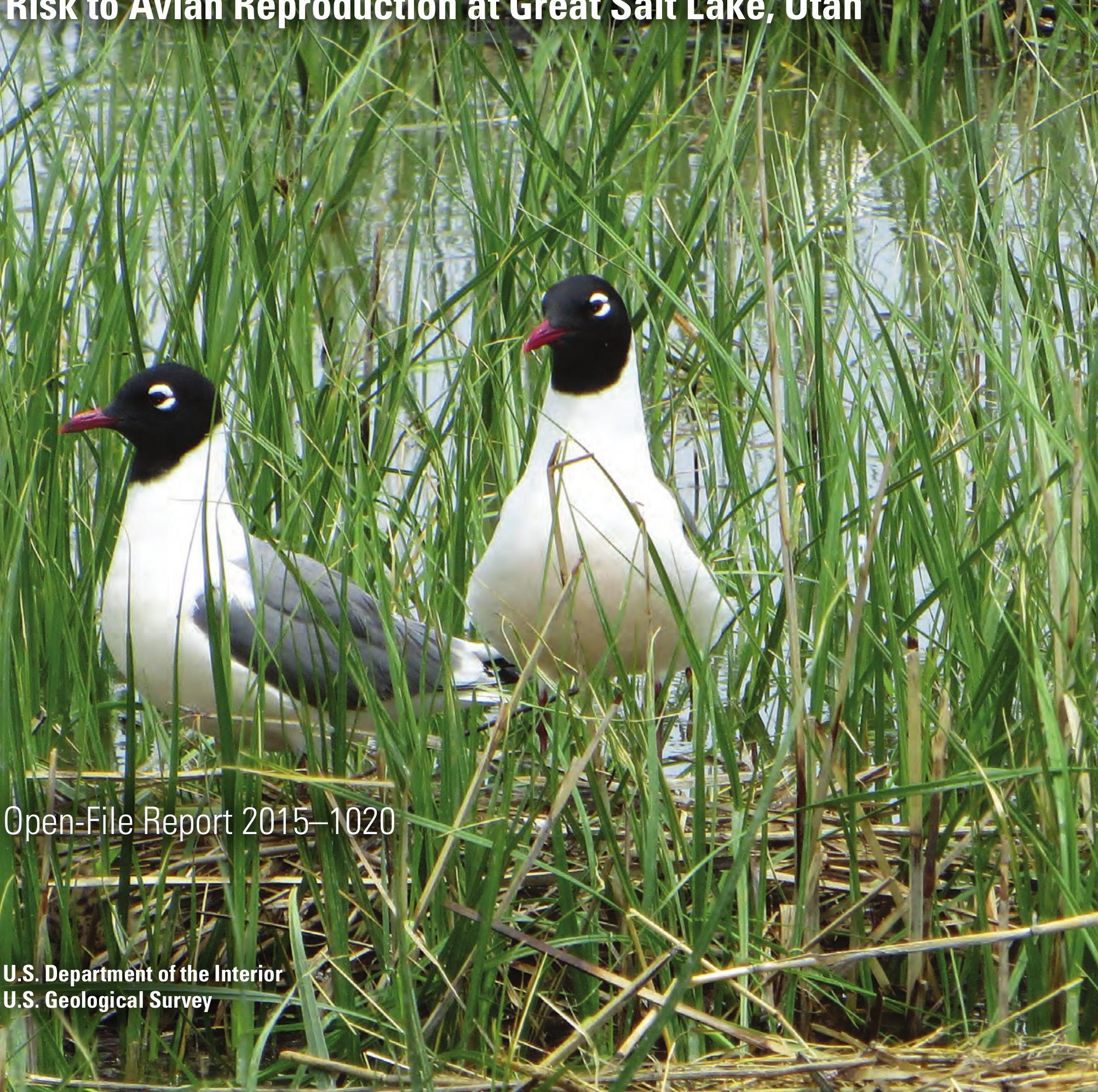


Cover: Franklin's gulls nesting at Bear River Migratory Bird Refuge, Great Salt Lake, Utah. Photograph taken by Josh Ackerman in 2012. 


\section{Mercury and Selenium Contamination in Waterbird Eggs and Risk to Avian Reproduction at Great Salt Lake, Utah}

By Joshua T. Ackerman, Mark P. Herzog, C. Alex Hartman, John Isanhart, Garth Herring, Sharon Vaughn, John F. Cavitt, Collin A. Eagles-Smith, Howard Browers, Chris Cline, and Josh Vest

Prepared in cooperation with the U.S. Fish and Wildlife Service

Open-File Report 2015-1020

U.S. Department of the Interior

U.S. Geological Survey 


\section{U.S. Department of the Interior \\ SALLY JEWELL, Secretary}

\section{U.S. Geological Survey \\ Suzette M. Kimball, Acting Director}

U.S. Geological Survey, Reston, Virginia: 2015

For more information on the USGS-the Federal source for science about the Earth, its natural and living resources, natural hazards, and the environment-visit http://www.usgs.gov or call 1-888-ASK-USGS

For an overview of USGS information products, including maps, imagery, and publications, visit $h$ ttp://www.usgs.gov/pubprod

To order this and other USGS information products, visit $h$ ttp://store.usgs.gov

Any use of trade, firm, or product names is for descriptive purposes only and does not imply endorsement by the U.S. Government.

Although this information product, for the most part, is in the public domain, it also may contain copyrighted materials as noted in the text. Permission to reproduce copyrighted items must be secured from the copyright owner.

Suggested citation:

Ackerman, J.T., Herzog, M.P., Hartman, C.A., Isanhart, J., Herring, G., Vaughn, S., Cavitt, J.F., Eagles-Smith, C.A., Browers, H., Cline, C., and Vest, J., 2015, Mercury and selenium contamination in waterbird eggs and risk to avian reproduction at Great Salt Lake, Utah: U.S. Geological Survey Open-File Report 2015-1020, 164 p., http://dx.doi.org/10.3133/ofr20151020.

ISSN 2331-1258 (online) 


\section{Acknowledgments}

This research was funded by the U.S. Fish and Wildlife Service's Environmental Contaminants Program (On-Refuge Investigations Program), with additional support from the Utah Department of Natural Resources' Forestry, Fire, and State Lands Program, Utah Department of Environmental Quality's Division of Water Quality, Environmental Protection Agency, U.S. Geological Survey's Science Support Program, U. S. Geological Survey Western Ecological Research Center, and U.S. Geological Survey Forest and Rangeland Ecosystem Science Center. We thank Bridget Olson, Bob Barrett, Laura Vernon, Cristopher Bittner, Sandra Spence, and Jack Sheets for project support. We thank the Bear River Migratory Bird Refuge (U.S. Fish and Wildlife Service), Timpie Springs Wildlife Management Area (Utah Department of Natural Resources), Farmington Bay Waterfowl Management Area (Utah Department of Natural Resources), Harold S. Crane Waterfowl Management Area (Utah Department of Natural Resources), Antelope Island State Park (Utah Department of Natural Resources), Inland Sea Shorebird Reserve (Rio Tinto - Kennecott Utah), areas near Saltair (Utah Department of Natural Resources), Weber State University, and U.S. Fish and Wildlife Service's Intermountain West Joint Venture for access and logistical support. We thank Ashley Casey, Trevor Watts, Robin Keister, Nacole Wilson, Stephen Peterson, Bridie Farmer, Matt Stevens, and David Cockerill for field and laboratory work. 
This page left intentionally blank 


\section{Contents}

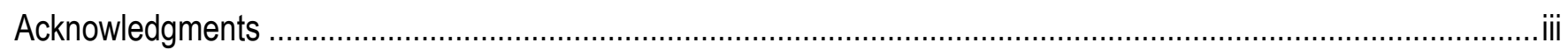

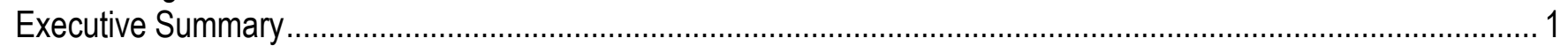

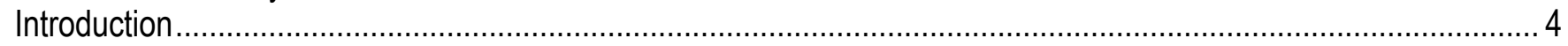

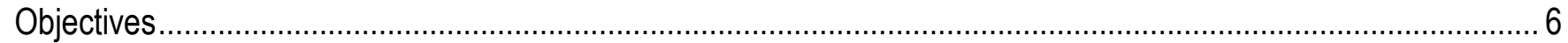

Methods

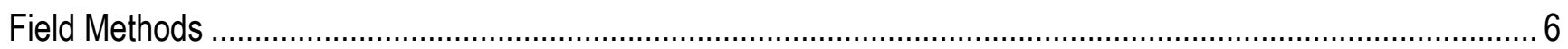

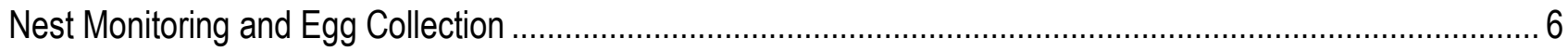

Failed-to-Hatch, Abandoned, and Random Eggs …………...........................................................

Nest Survival and Surrogate Egg Technique .....................................................................................

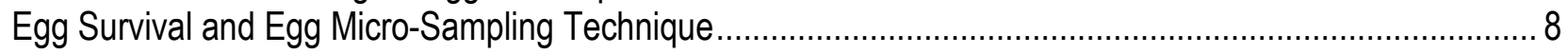

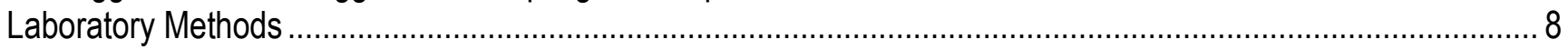

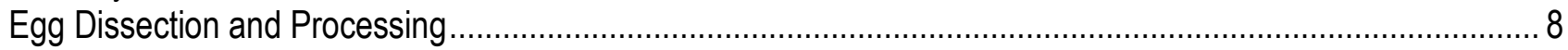

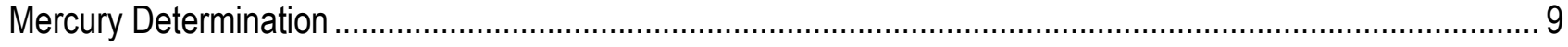

Selenium Determination ..........................................................................................................

Egg Contaminant Concentrations on a Fresh Wet Weight Basis .............................................................. 10

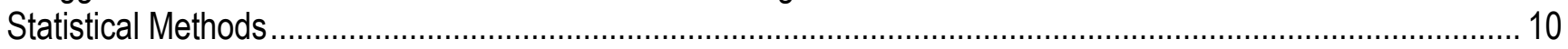

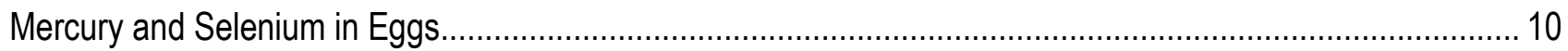

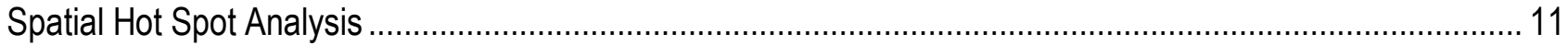

Effects of Mercury and Selenium on Bird Reproduction ........................................................................ 11

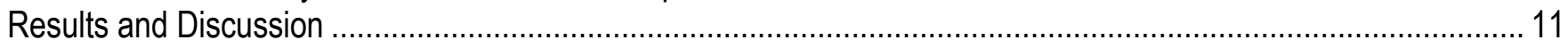

Objective 1: Evaluate the Risk of Mercury and Selenium Contamination to Birds Breeding within

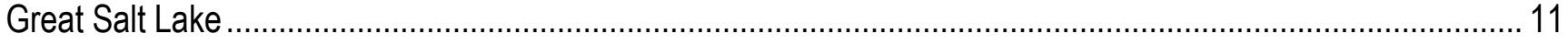

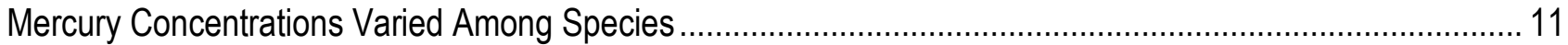

Selenium Concentrations Varied Among Species ................................................................................... 12

Molar Ratio of Mercury to Selenium Among Species ........................................................................... 12

Mercury and Selenium Risk to Birds .............................................................................................. 13

Objective 2: Examine the Spatial Variation in Egg Mercury and Selenium Concentrations among Wetlands of

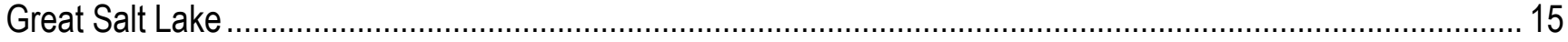

Mercury Concentrations Varied Among Wetland Sites........................................................................... 15

Selenium Concentrations Varied Among Wetland Sites........................................................................ 16

Objective 3: Assess the Effect of Mercury on Waterbird Egg Hatchability and Nest Survival at Bear River

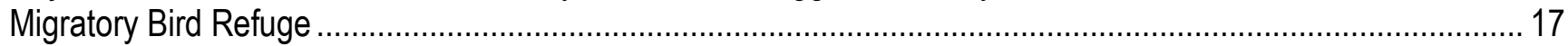

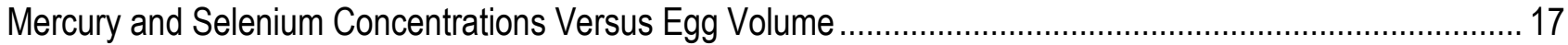

Mercury Concentrations in Random Eggs Versus Failed-to-Hatch Eggs and Abandoned Eggs ...................... 18

Effects of Mercury Concentrations on Nest Survival: Surrogate Egg Method................................................ 19

Effects of Mercury Concentrations on Nest Survival: Micro-Sampled Egg Method ....................................... 20

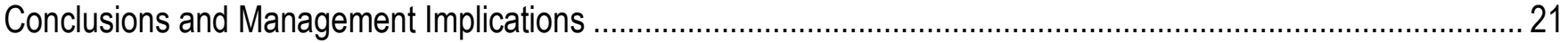

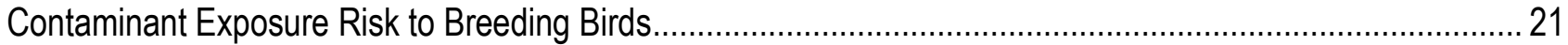

Wetland-Specific Exposure and Management..................................................................................... 21

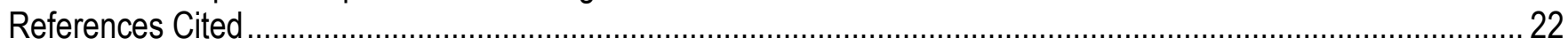


Appendix A. Maps showing total mercury concentrations ( $\mathrm{THg} ; \mu \mathrm{g} / \mathrm{g} \mathrm{fww}$ ) in eggs of 33 species of birds breeding in Great Salt Lake, Utah, 2010-2012.

Appendix B. Hot spot maps showing total mercury concentrations ( $\mathrm{THg} ; \mu \mathrm{g} / \mathrm{g} \mathrm{fww}$ ) in eggs of 11 species of birds breeding in Great Salt Lake, Utah, 2010-2012

Appendix C. Maps showing selenium concentrations (Se; $\mu \mathrm{g} / \mathrm{g}$ fww) in eggs of 32 species of birds

breeding in Great Salt Lake, Utah, 2010-2011.

\section{Figures}

Figure 1. Map showing wetland sites at Bear River Migratory Bird Refuge in Great Salt Lake, Utah, 2010-2012

Figure 2. Map showing study sites and locations where eggs from 33 bird species were sampled (solid circles) in Great Salt Lake, Utah, 2010-2012.

Figure 3. Selenium concentration in bird eggs $(\mu \mathrm{g} / \mathrm{g} \mathrm{fww})$ as determined by (1) hydride generation flow injection atomic spectroscopy (FIAS) and (2) inductively coupled mass spectrometry (ICP-MS) for birds breeding in Great Salt Lake, Utah, 2010-2011

Figure 4. Total mercury concentrations ( $\mu \mathrm{g} / \mathrm{g} \mathrm{fww}$ ) in eggs from 33 bird species breeding in

Great Salt Lake, Utah, 2010-2012

Figure 5. Selenium concentrations $(\mu \mathrm{g} / \mathrm{g} \mathrm{fww})$ in eggs from 32 bird species breeding in

Great Salt Lake, Utah, 2010-2011

Figure 6. Correlation between egg selenium concentrations ( $\mu \mathrm{g} / \mathrm{g} \mathrm{fww})$ and egg total mercury

concentrations ( $\mu \mathrm{g} / \mathrm{g} \mathrm{fww}$ ) among 32 bird species breeding in Great Salt Lake, Utah, 2010-2011

Figure 7. Correlation between species mean egg selenium concentrations $(\mu \mathrm{g} / \mathrm{g} \mathrm{fww})$ and mean egg total

mercury concentrations ( $\mu \mathrm{g} / \mathrm{g} \mathrm{fww}$ ) among 32 bird species breeding in Great Salt Lake, Utah, 2010-2011

Figure 8. Molar ratio of total mercury:selenium (top panel) and selenium:total mercury (bottom panel) in

eggs from 32 bird species breeding in Great Salt Lake, Utah, 2010-2011.

Figure 9. Total mercury concentrations $(\mu \mathrm{g} / \mathrm{g} \mathrm{fww})$ in eggs of American avocets breeding in various wetland sites within Great Salt Lake, Utah, 2010-2012.

Figure 10. Total mercury concentrations $(\mu \mathrm{g} / \mathrm{g} \mathrm{fww})$ in eggs of American coots breeding in various wetland sites within Great Salt Lake, Utah, 2010-2012.

Figure 11. Total mercury concentrations $(\mu \mathrm{g} / \mathrm{g} \mathrm{fww})$ in eggs of black-necked stilts breeding in various wetland sites within Great Salt Lake, Utah, 2010-2012.

Figure 12. Total mercury concentrations ( $\mu \mathrm{g} / \mathrm{g} \mathrm{fww}$ ) in eggs of California gulls breeding in various wetland sites within Great Salt Lake, Utah, 2010-2012.

Figure 13. Total mercury concentrations $(\mu \mathrm{g} / \mathrm{g} \mathrm{fww})$ in eggs of cliff swallows breeding in various wetland sites within Great Salt Lake, Utah, 2010-2012

Figure 14. Total mercury concentrations ( $\mu \mathrm{g} / \mathrm{g} \mathrm{fww}$ ) in eggs of Forster's terns breeding in various wetland sites within Great Salt Lake, Utah, 2010-2012.

Figure 15. Total mercury concentrations ( $\mu \mathrm{g} / \mathrm{g} \mathrm{fww})$ in eggs of Franklin's gulls breeding in various wetland sites within Great Salt Lake, Utah, 2010-2012...

Figure 16. Total mercury concentrations ( $\mu \mathrm{g} / \mathrm{g} \mathrm{fww}$ ) in eggs of killdeer breeding in various wetland sites within Great Salt Lake, Utah, 2010-2012

Figure 17. Total mercury concentrations $(\mu \mathrm{g} / \mathrm{g} \mathrm{fww})$ in eggs of marsh wrens breeding in various wetland sites within Great Salt Lake, Utah, 2010-2012. 
Figure 18. Total mercury concentrations $(\mu \mathrm{g} / \mathrm{g} \mathrm{fww})$ in eggs of pied-billed grebes breeding in various wetland sites within Great Salt Lake, Utah, 2010-2012.

Figure 19. Total mercury concentrations $(\mu \mathrm{g} / \mathrm{g} \mathrm{fww})$ in eggs of redhead ducks breeding in various wetland sites within Great Salt Lake, Utah, 2010-2012. 44

Figure 20. Total mercury concentrations $(\mu \mathrm{g} / \mathrm{g} \mathrm{fww})$ in eggs of white-faced ibis breeding in various wetland sites within Great Salt Lake, Utah, 2010-2012...

Figure 21. Total mercury concentrations $(\mu \mathrm{g} / \mathrm{g} \mathrm{fww})$ in eggs of yellow-headed blackbirds breeding in various wetland sites within Great Salt Lake, Utah, 2010-2012.

Figure 22. Selenium concentrations ( $\mu \mathrm{g} / \mathrm{g} \mathrm{fww}$ ) in eggs of American avocets breeding in various wetland sites within Great Salt Lake, Utah, 2010-2012.

Figure 23. Selenium concentrations $(\mu \mathrm{g} / \mathrm{g} \mathrm{fww})$ in eggs of black-necked stilts breeding in various wetland sites within Great Salt Lake, Utah, 2010-2012.

Figure 24. Selenium concentrations ( $\mu \mathrm{g} / \mathrm{g} \mathrm{fww})$ in eggs of California gull breeding in various wetland sites within Great Salt Lake, Utah, 2010-2012.

Figure 25. Selenium concentrations $(\mu \mathrm{g} / \mathrm{g} \mathrm{fww})$ in eggs of Forster's terns breeding in various wetland sites within Great Salt Lake, Utah, 2010-2012.

Figure 26. Selenium concentrations ( $\mu \mathrm{g} / \mathrm{g} \mathrm{fww}$ ) in eggs of Franklin's gulls breeding in various wetland sites within Great Salt Lake, Utah, 2010-2012.

Figure 27. Selenium concentrations ( $\mu \mathrm{g} / \mathrm{g} \mathrm{fww}$ ) in eggs of marsh wrens breeding in various wetland sites within Great Salt Lake, Utah, 2010-2012....

Figure 28. Selenium concentrations $(\mu \mathrm{g} / \mathrm{g} \mathrm{fww})$ in eggs of pied-billed grebes breeding in various wetland sites within Great Salt Lake, Utah, 2010-2012.

Figure 29. Selenium concentrations ( $\mu \mathrm{g} / \mathrm{g} \mathrm{fww}$ ) in eggs of redhead ducks breeding in various wetland sites within Great Salt Lake, Utah, 2010-2012....

Figure 30. Selenium concentrations ( $\mu \mathrm{g} / \mathrm{g} \mathrm{fww}$ ) in eggs of white-faced ibis breeding in various wetland sites within Great Salt Lake, Utah, 2010-2012....

Figure 31. Selenium concentrations $(\mu \mathrm{g} / \mathrm{g} \mathrm{fww})$ in eggs of yellow-headed blackbirds breeding in various wetland sites within Great Salt Lake, Utah, 2010-2012.

Figure 32. Egg volume in relation to natural log (In) transformed egg mercury concentrations ( $\mathrm{THg} \mu \mathrm{g} / \mathrm{g}$ fww) in snowy plovers, gadwall, black-necked stilts, and Forster's terns, and increased with egg mercury concentrations in black-crowned night herons breeding in Great Salt Lake, Utah, 2010-2012

Figure 33. Egg volume in relation to natural $\log (\mathrm{In})$ transformed egg selenium concentrations (Se $\mu \mathrm{g} / \mathrm{g}$ fww) in Forster's terns, American coots, and eared grebes breeding in Great Salt Lake, Utah, 2010-2011.

Figure 34. Total mercury concentrations ( $\mathrm{THg} \mu \mathrm{g} / \mathrm{g}$ fww; least squares means \pm standard error) in randomly sampled eggs from successful nests (random), naturally abandoned eggs (abandoned), and failed to hatch eggs in nests where at least one other egg in the clutch successfully hatched (failed to hatch) for 5 species of birds breeding at Bear River Migratory Bird Refuge in Great Salt Lake, Utah, 2012 


\section{Tables}

Table 1. Common, scientific, and short names for 33 species of birds studied that nested in Great Salt Lake, Utah, 2010-2012

Table 2. Correlations between selenium concentrations and total mercury concentrations $(\mu \mathrm{g} / \mathrm{g}$ fww) in eggs from 32 bird species breeding in Great Salt Lake, Utah, 2010-2011.

Table 3. Percentage of eggs exceeding various toxicity levels of mercury and selenium concentrations for 33 bird species breeding in Great Salt Lake, Utah, 2010-2012.

Table 4. Total mercury and selenium concentrations $(\mu \mathrm{g} / \mathrm{g} \mathrm{fww})$ in eggs from 33 bird species breeding in Great Salt Lake, Utah, 2010-2012

Table 5. Factors influencing egg mercury concentrations in 33 bird species breeding in Great Salt Lake, Utah, 2010-2012

Table 6. Factors influencing egg selenium concentrations in 33 bird species breeding in Great Salt Lake, Utah, 2010-2012

Table 7. Influence of total mercury concentrations on egg volume in 33 bird species breeding in Great Salt Lake, Utah. 2010-2012

Table 8. Influence of selenium concentrations on egg volume in 33 bird species breeding in Great Salt Lake, Utah, 2010-2012

Table 9. Summary of fates for micro-sampled, sham, and control eggs within nests that were micro-sampled for albumen mercury concentrations for American avocets, black-necked stilts, and Forster's terns breeding in Great Salt Lake, Utah, 2012

Table 10. Summary of fates for micro-sampled and not micro-sampled nests for American avocets, black-necked stilts, and Forster's terns breeding in Great Salt Lake, Utah in 2012

Table 11. Summary of fates within nests that were micro-sampled for albumen mercury concentrations for American avocets, black-necked stilts, and Forster's terns breeding in Great Salt Lake, Utah, 2012 


\section{Conversion Factors}

\begin{tabular}{|c|c|c|}
\hline Multiply & By & To obtain \\
\hline \multicolumn{3}{|c|}{ Length } \\
\hline centimeter $(\mathrm{cm})$ & 0.3937 & inch (in.) \\
\hline millimeter (mm) & 0.03937 & inch (in.) \\
\hline meter $(\mathrm{m})$ & 3.281 & foot $(\mathrm{ft})$ \\
\hline kilometer $(\mathrm{km})$ & 0.6214 & mile (mi) \\
\hline meter $(\mathrm{m})$ & 1.094 & yard (yd) \\
\hline \multicolumn{3}{|c|}{ Area } \\
\hline square meter $\left(\mathrm{m}^{2}\right)$ & 0.0002471 & acre \\
\hline square meter $\left(\mathrm{m}^{2}\right)$ & 10.76 & square foot $\left(\mathrm{ft}^{2}\right)$ \\
\hline hectare (ha) & 2.471 & acre \\
\hline hectare (ha) & 0.003861 & square mile $\left(\mathrm{mi}^{2}\right)$ \\
\hline square kilometer $\left(\mathrm{km}^{2}\right)$ & 0.3861 & square mile $\left(\mathrm{mi}^{2}\right)$ \\
\hline square kilometer $\left(\mathrm{km}^{2}\right)$ & 247.1 & acre \\
\hline hectare (ha) & 0.003861 & square mile $\left(\mathrm{mi}^{2}\right)$ \\
\hline \multicolumn{3}{|c|}{ Volume } \\
\hline liter (L) & 0.264172 & gallon (gal) \\
\hline milliliter $(\mathrm{mL})$ & 0.0333814 & ounce, fluid (fl. oz) \\
\hline \multicolumn{3}{|c|}{ Mass } \\
\hline gram $(\mathrm{g})$ & 0.03527 & ounce, avoirdupois (oz) \\
\hline milligram (mg) & 0.00003527 & ounce, avoirdupois (oz) \\
\hline microgram $(\mu \mathrm{g})$ & 0.00000003527 & ounce, avoirdupois (oz) \\
\hline \multicolumn{3}{|c|}{ Density } \\
\hline gram per cubic centimeter $\left(\mathrm{g} / \mathrm{cm}^{3}\right)$ & 62.4220 & pound per cubic foot $\left(\mathrm{lb} / \mathrm{ft}^{3}\right)$ \\
\hline
\end{tabular}

Temperature in degrees Celsius $\left({ }^{\circ} \mathrm{C}\right)$ may be converted to degrees Fahrenheit $\left({ }^{\circ} \mathrm{F}\right)$ as follows:

$$
{ }^{\circ} \mathrm{F}=\left(1.8 \times{ }^{\circ} \mathrm{C}\right)+32 \text {. }
$$




\section{Abbreviations and Acronyms}

\begin{tabular}{ll}
\hline $\mathrm{dw}$ & dry weight \\
$\mathrm{ww}$ & wet weight \\
$\mathrm{fww}$ & fresh wet weight \\
$\mathrm{Hg}$ & mercury \\
$\mathrm{THg}$ & total mercury \\
$\mathrm{MeHg}$ & methylmercury \\
$\mathrm{Se}$ & selenium \\
\hline
\end{tabular}




\section{Mercury and Selenium Contamination in Waterbird Eggs and Risk to Avian Reproduction at Great Salt Lake, Utah}

By Joshua T. Ackerman1, Mark P. Herzog ${ }^{1}$, C. Alex Hartman¹, John Isanhart², Garth Herring ${ }^{1}$, Sharon Vaughn², John F. Cavitt ${ }^{3}$, Collin A. Eagles-Smith1, Howard Browers², Chris Cline'2, and Josh Vest²

\section{Executive Summary}

The wetlands of the Great Salt Lake ecosystem are recognized regionally, nationally, and hemispherically for their importance as breeding, wintering, and migratory habitat for diverse groups of waterbirds. Bear River Migratory Bird Refuge is the largest freshwater component of the Great Salt Lake ecosystem and provides critical breeding habitat for more than 60 bird species. However, the Great Salt Lake ecosystem also has a history of both mercury and selenium contamination, and this pollution could reduce the health and reproductive success of waterbirds. The overall objective of this study was to evaluate the risk of mercury and selenium contamination to birds breeding within Great Salt Lake, especially at Bear River Migratory Bird Refuge, and to identify the waterbird species and areas at greatest risk to contamination. We sampled eggs from 33 species of birds breeding within wetlands of Great Salt Lake during 2010-2012 and focused on American avocets (Recurvirostra americana), blacknecked stilts (Himantopus mexicanus), Forster's terns (Sterna forsteri), white-faced ibis (Plegadis chihi), and marsh wrens (Cistothorus palustris) for additional studies of the effects of contaminants on reproduction.

Mercury concentrations in eggs differed substantially among the 33 bird species studied. Caspian terns (Hydroprogne caspia; $0.87 \pm 0.09$ micrograms per gram fresh wet weight $[\mu \mathrm{g} / \mathrm{g}$ fww]) and Forster's terns $(0.64 \pm 0.05 \mu \mathrm{g} / \mathrm{g}$ fww $)$ had the highest egg mercury concentrations and Canada geese (Branta canadensis; $0.01 \pm 0.01 \mu \mathrm{g} / \mathrm{g}$ fww) had the lowest egg mercury concentrations. Trophic level alone did not explain the majority of the variation observed in egg mercury concentrations among species. Snowy plovers (Charadrius nivosus; $0.44 \pm 0.08 \mu \mathrm{g} / \mathrm{g}$ fww) had the third highest egg mercury concentrations and were $189 \%$ higher than those in the closely related killdeer (Charadrius vociferus) $(0.15 \pm 0.02 \mu \mathrm{g} / \mathrm{g}$ fww $)$. Similarly, black-necked stilts $(0.30 \pm 0.02 \mu \mathrm{g} / \mathrm{g}$ fww $)$ had the fourth highest egg mercury concentrations and were $142 \%$ higher than those in the related American avocet $(0.12 \pm 0.01$ $\mu \mathrm{g} / \mathrm{g}$ fww). Among songbirds, egg mercury concentrations were highest in barn swallows (Hirundo rustica; $0.11 \pm 0.01 \mu \mathrm{g} / \mathrm{g}$ fww) and marsh wrens (Cistothorus palustris; $0.10 \pm 0.01 \mu \mathrm{g} / \mathrm{g}$ fww), and mercury concentrations in marsh wren eggs were $157 \%$ higher than yellow-headed blackbirds (Xanthocephalus xanthocephalus; $0.04 \pm 0.01 \mu \mathrm{g} / \mathrm{g}$ fww) and $41 \%$ higher than red-winged blackbirds (Agelaius phoeniceus) $(0.07 \pm 0.01 \mu \mathrm{g} / \mathrm{g}$ fww).

\footnotetext{
${ }^{1}$ U.S. Geological Survey.

${ }^{2}$ U.S. Fish and Wildlife Service.

${ }^{3}$ Weber State University.
} 
Selenium concentrations in eggs also differed among the 32 bird species studied (selenium concentrations were not measured in one species, common yellowthroats [Geothlypis trichas]). Eared grebes (Podiceps nigricollis; $1.11 \pm 0.05 \mu \mathrm{g} / \mathrm{g}$ fww), Forster's terns $(0.99 \pm 0.04 \mu \mathrm{g} / \mathrm{g}$ fww), blackcrowned night herons (Nycticorax nycticorax; $0.98 \pm 0.05 \mu \mathrm{g} / \mathrm{g}$ fww), snowy plovers $(0.96 \pm 0.06 \mu \mathrm{g} / \mathrm{g}$ fww), Franklin's gulls (Leucophaeus pipixcan; $0.95 \pm 0.04 \mu \mathrm{g} / \mathrm{g}$ fww), and redhead ducks (Aythya americana; $0.93 \pm 0.06 \mu \mathrm{g} / \mathrm{g}$ fww) had the highest egg selenium concentrations, and Canada geese $(0.30 \pm 0.02 \mu \mathrm{g} / \mathrm{g}$ fww $)$ had the lowest egg selenium concentrations. Selenium concentrations in eggs were either weakly or not correlated with mercury concentrations in eggs within and across species. Mean mercury to selenium molar ratios among species were less than 1.0, and each individual egg's mercury to selenium molar ratio was less than 1.0, except for two individual Caspian tern eggs. Therefore, based on the molar ratio, there was an excess of selenium to mercury in almost all bird eggs. Mercury concentrations in eggs differed among wetland sites in 8 of the 25 bird species and differed among regions in 7 of the 12 bird species where we could test these effects. Mercury concentrations in eggs tended to be lower at the Bear River Migratory Bird Refuge than at other areas throughout Great Salt Lake (which received only limited sampling). In particular, mercury concentrations in eggs collected near Antelope Island and at Farmington Bay were consistently higher than all other regions, especially Bear River Migratory Bird Refuge. Within Bear River Migratory Bird Refuge, eggs collected near Wetland Complex 3 tended to have the highest mercury concentrations. For example, mercury concentrations in eggs were highest for American coots in 3B and 3E, for Franklin's gulls in 3K, for pied-billed grebes (Podilymbus podiceps) in 3I, for redheads in 3D, and for yellowheaded blackbirds in 3E. Wetland $5 \mathrm{C}$ had the highest mercury concentrations in eggs of American avocets and Forster's terns. For songbirds, mercury concentrations in eggs collected in 8GSL were typically the highest of any other wetland sampled at Bear River Migratory Bird Refuge. Selenium concentrations in eggs also differed among wetland sites in 6 of the 22 bird species for which we could test the effect of wetland site.

Mercury concentrations in eggs also differed among years in 7 of the 33 bird species and increased with nest initiation date in 5 of the 33 bird species. Mercury concentrations were lowest in 2012 and were similar between 2010 and 2011. On average, mercury concentrations in eggs were 53\% and 60\% lower in American avocets, 35\% and 30\% lower in black-necked stilts, 46\% higher and 14\% lower in Forster's terns, $21 \%$ and 15\% lower in marsh wrens, $24 \%$ and $27 \%$ lower in white-faced ibis, and 34\% and 36\% lower in yellow-headed black birds in 2012 compared to 2010 and 2011, respectively. Selenium concentrations in eggs also differed among years in 6 of the 20 bird species where we could test the effect of year. On average, selenium concentrations in eggs were $60 \%$ higher in mallard, 50\% higher in snowy plovers, $45 \%$ higher in pied-billed grebes, 38\% higher in Caspian terns, $22 \%$ higher in great-blue herons, 18\% higher in Franklin's gulls, and 29\% lower in pied-billed grebes in 2010 compared to 2011.

Mercury can potentially influence bird reproduction in several ways, including altered parental behavior, egg size, embryo mortality, hatching failure, and reduced chick growth, health, and survival. In this study, we focused on the potential influence of mercury on egg hatchability and nest survival by (1) comparing mercury concentrations in randomly sampled eggs to mercury concentrations in failed-tohatch eggs and abandoned eggs, (2) examining the influence of mercury concentrations in surrogate eggs on the fate of the remaining eggs in the clutch, and (3) investigating the influence of mercury concentrations in micro-sampled eggs to the fate of all eggs in the clutch. We also evaluated the relationship between mercury and selenium concentrations in eggs and egg size. 
Mercury concentrations in eggs differed among random, abandoned, and failed-to-hatch eggs in two of the five species studied. In marsh wrens, mercury concentrations were $152 \%$ higher in abandoned eggs $(0.20 \pm 0.07 \mu \mathrm{g} / \mathrm{g}$ fww $)$ than in randomly sampled eggs from successful nests $(0.08 \pm 0.01$ $\mu \mathrm{g} / \mathrm{g}$ fww). Similarly, in white-faced ibis, mercury concentrations were $74 \%$ higher in abandoned eggs $(0.10 \pm 0.02 \mu \mathrm{g} / \mathrm{g}$ fww $)$ than in randomly sampled eggs from successful nests $(0.06 \pm 0.01 \mu \mathrm{g} / \mathrm{g}$ fww $)$. However, mercury concentrations in American avocet, black-necked stilt, and Forster's tern eggs did not differ among random eggs from successful nests, naturally abandoned eggs, and failed-to-hatch eggs.

We found no effect of the surrogate or micro-sampled egg's mercury concentration on nest survival for American avocets, black-necked stilts, Forster's terns, marsh wrens, or white-faced ibis. These specific effects studies occurred in 2012 which, we later learned, had substantially lower mercury concentrations in eggs than in either 2010 or 2011 (by 14 to $60 \%$, depending on the species and year). Repeating these studies on mercury's effect on nest survival in more representative years when egg mercury concentrations are higher would confirm that egg mercury concentrations are not greatly influencing nest survival in birds breeding in Great Salt Lake ecosystem.

Egg volume was negatively correlated with mercury concentrations in 5 of the 28 bird species with adequate sample sizes. In particular, egg volume decreased with mercury concentrations in snowy plovers, gadwall (Anas strepera), black-necked stilts, and Forster's terns. Egg volume also was negatively correlated with selenium concentrations in 3 of the 25 bird species with adequate sample sizes, including eared grebes, Forster's terns, and American coots (Fulica americana). However, the negative correlation between egg volume and contaminant concentrations is correlational and may not be causal, and further study would be needed to evaluate whether the negative relationship is indicative of reproductive impairment.

In general, mercury and selenium concentrations in eggs of birds breeding in Great Salt Lake were considered moderate to high. Compared to the highly contaminated San Francisco Bay Estuary for which we have direct comparable data, mercury concentrations in eggs of Great Salt Lake were approximately 16\% higher in Caspian terns, 56\% lower in Forster's terns, 55\% lower in black-necked stilts, and 45\% lower in American avocets. Because the sensitivity of birds to mercury and selenium toxicity can differ widely among species, it is difficult to compare egg mercury and selenium concentrations against known toxicity benchmarks. Therefore, we have provided several toxicity benchmarks in eggs that have been suggested to impair bird reproduction. For songbirds, 52\% of barn swallows, $50 \%$ of common yellowthroats, $37 \%$ of cliff swallows (Petrochelidon pyrrhonota), $18 \%$ of marsh wrens (Cistothorus palustris), $2 \%$ of yellow-headed blackbirds, $0 \%$ of brown-headed cowbirds (Molothrus ater), and 0\% of red-winged blackbirds (Agelaius phoeniceus) exceeded $0.11 \mu \mathrm{g} / \mathrm{g}$ fww, which is a benchmark that has been suggested to reduce nest success by $10 \%$ in songbirds (Jackson and others, 2011). Similarly, $86 \%$ of Caspian terns, 35\% of Forster's terns, $6 \%$ of black-necked stilts, and $0 \%$ of American avocets, exceeded $0.65 \mu \mathrm{g} / \mathrm{g}$ fww, which is a level known to induce methylmercury demethylation in the livers of these four species (Eagles-Smith and others, 2009b; Ackerman and others, 2014). Although injected mercury is more toxic to embryos than naturally derived mercury, Heinz and others (2009) showed that ibis, herons, and egrets are among the most sensitive species to mercury exposure and that their median lethal concentration $\left(\mathrm{LC}_{50}\right)$ for eggs was below $0.25 \mu \mathrm{g} / \mathrm{g}$ fww. Using this value, we found that $50 \%$ of great egrets (Ardea alba), 40\% of snowy egrets (Egretta thula), 12\% of black-crowned night herons, $8 \%$ of great blue herons (Ardea herodias), and 2\% of white-faced ibis exceeded $0.25 \mu \mathrm{g} / \mathrm{g}$ fww. Ducks are thought to be less sensitive to mercury 
toxicity, and a toxicity threshold of $0.5 \mu \mathrm{g} / \mathrm{g}$ fww to $1.0 \mu \mathrm{g} / \mathrm{g}$ fww is commonly used for these species (Heinz and others, 2009). We found that no eggs of ducks or geese exceeded $0.5 \mu \mathrm{g} / \mathrm{g}$ fww. Other species with less-well-defined toxicity thresholds but that had egg mercury concentrations over $0.5 \mu \mathrm{g} / \mathrm{g}$ fww included $20 \%$ of snowy plovers, $6 \%$ of double-crested cormorants, $2 \%$ of pied-billed grebes, and $1 \%$ of American coots.

There were fewer eggs that exceeded toxicity benchmarks for selenium. We estimated all egg selenium concentrations on a fresh wet weight basis, and therefore we first converted existing toxicity levels on a dry weight basis into equivalent egg selenium concentrations on a fresh wet weight basis. Selenium concentrations in eggs greater than $5.0 \mu \mathrm{g} / \mathrm{g} \mathrm{dw}$ (dry weight; $1.1 \mu \mathrm{g} / \mathrm{g}$ fww) are considered to exceed the normal range of egg values and $6.4 \mu \mathrm{g} / \mathrm{g} \mathrm{dw}(1.41 \mu \mathrm{g} / \mathrm{g}$ fww $)$ is a level that is approaching reproductive impairment (Ohlendorf and Heinz, 2011). These concentrations also correspond to a level that would begin to trigger a regulatory response by the Utah Department of Natural Resources, Division of Water Quality in the Gilbert Bay area of Great Salt Lake (Utah Administrative Code - UAC R317-2-14; http://www.rules.utah.gov/publicat/code/r317/r317-002.htm\#T16; their table 2.14.2, footnote 14). Only eared grebe and black-crowned night heron eggs exceeded $1.41 \mu \mathrm{g} / \mathrm{g}$ fww $(\sim 6.4 \mu \mathrm{g} / \mathrm{g}$ $\mathrm{dw}$ ). Additionally, $46 \%$ of eared grebe, $20 \%$ of snowy plover, $19 \%$ of black-crowned night heron, $17 \%$ of redhead duck (Aythya americana), 14\% of Forster's tern, 10\% of American avocet, 10\% of Franklin's gull, $4 \%$ of California gull (Larus californicus), and 3\% of black-necked stilt eggs exceeded $1.1 \mu \mathrm{g} / \mathrm{g}$ fww (about $5.0 \mu \mathrm{g} / \mathrm{g} \mathrm{dw}$ ).

Overall, a substantial percentage of eggs sampled from wetlands of Great Salt Lake had mercury or selenium concentrations greater than common toxicity benchmarks or regulatory thresholds. These risk levels, together with the effects of higher mercury concentrations in abandoned eggs than in random eggs for some species, indicates that these contaminants could be impairing bird reproduction in the Great Salt Lake ecosystem and that this continues to be an area of conservation concern that warrants close monitoring.

\section{Introduction}

Mercury contamination is an issue of national conservation concern, especially in wetlands where biogeochemical conditions are known to stimulate microbial methylmercury production (Hall and others, 2008). Wetlands provide critical foraging and nesting habitat for migratory waterbirds, which can place them at high risk to deleterious toxicological effects from methylmercury exposure.

Methylmercury is a potent neurotoxin that readily bioaccumulates through food web pathways via the diet (Wiener and others, 2003) and can reach elevated concentrations in top predators such as piscivorous waterbirds (Ackerman and others, 2008a; Eagles-Smith and others, 2009a) and lower trophic level species that forage in high-exposure habitats, such as shorebirds (Ackerman and others, 2007). Avian reproduction is among the most sensitive toxicity endpoints to methylmercury exposure (reviews by Thompson, 1996; Wiener and others, 2003; Scheuhammer and others, 2007). Impaired reproduction due to mercury contamination can be manifested in several ways, but reduced egg hatchability is among the most demographically significant effects of mercury toxicity (Albers and others, 2007; Heinz and others, 2009). 
The wetlands of the Great Salt Lake ecosystem, located in northern Utah, are recognized regionally, nationally, and hemispherically for their importance as breeding, migratory, and wintering habitat for millions of waterbirds. The saline waters and freshwater wetlands comprise one of the most important breeding and staging areas for colonial waterbirds, waterfowl, and shorebirds in Western North America. For example, Great Salt Lake hosts approximately 25,000 breeding white-faced ibis (Plegadis chihi), which is the world's largest breeding population (Cavitt and others, 2014).

Additionally, approximately 5,500 snowy plovers (Charadrius nivosus) breed in Great Salt Lake, which is the species' largest breeding population and represents $23 \%$ of the continental population and $63 \%$ of the inland population (Thomas and others, 2012). Because of the continental and hemispheric importance of Great Salt Lake to several migratory and breeding waterbirds, it has been designated a site of Hemispheric Importance in the Western Hemisphere Shorebird Reserve Network (Aldrich and Paul, 2002).

Bear River Migratory Bird Refuge (hereafter BRMB Refuge) is the largest freshwater component of the Great Salt Lake ecosystem. BRMB Refuge provides critical habitat for migratory birds within the Great Salt Lake ecosystem by managing more than 28,700 ha of various freshwater wetland habitats and alkali mudflats. More than 220 bird species use BRMB Refuge during some portion of their annual cycle and at least 67 bird species are known to breed within habitats of the BRMB Refuge. Some of the most abundant breeding birds include American avocets (Recurvirostra americana; 4,800), white-faced ibis (25,000), Franklin's gulls (Leucophaeus pipixcan; 4,000), and black-necked stilts (Himantopus mexicanus; 2,500; H. Browers, unpub. data). These breeding waterbird species utilize a diverse array of habitats for foraging that are common to BRMB Refuge and the adjacent Great Salt Lake, including freshwater wetlands, brackish wetlands, and mudflats (Aldrich and Paul, 2002).

Although Great Salt Lake's wetland and saline habitats, and particularly BRMB Refuge, host large proportions of the continental populations of several migratory bird species, little is known about the extent to which anthropogenic derived contaminants affect these species. Elevated mercury and selenium concentrations have recently been documented in both fish and waterbirds in Utah and the Great Salt Lake watershed, causing concern that wildlife may be affected. High concentrations of several trace elements, including mercury, also have been detected in sediments from Great Salt Lake and its watershed (Naftz and others, 2008a). Water samples exceeded the total mercury standard for protection of aquatic life in marine systems and mercury concentrations were among the highest values observed for saline systems (Naftz and others, 2008a). Sources of inorganic mercury and selenium in the Great Salt Lake ecosystem are unclear; however, atmospheric deposition is a major source of mercury to many aquatic environments (Driscoll and others, 2013). The BRMB Refuge is located downwind from regionally large sources of atmospheric mercury and may be especially susceptible to accumulation of local and regional deposits of atmospheric mercury because of the geophysical properties of the adjacent Great Salt Lake (Stutz and others, 2002; Naftz and others, 2008a). The Bear River and associated wetland complexes, including BRMB Refuge, contribute a significant amount of selenium to Great Salt Lake (Naftz and others, 2008b). Much of the selenium loading associated with Bear River, which supplies water to BRMB Refuge, is likely attributable to contamination from irrigation wastewater as is common in many Western U.S. watersheds (Seiler and others, 2003; Naftz and others, 2008b; Diaz and others, 2009). Although the inorganic source of mercury is unclear, the most bioavailable and toxic form, methylmercury, is produced by microbes within wetlands (Driscoll and others, 2013). Therefore, wetlands can be sources of methylmercury. Accordingly, mercury concentrations in several wetland-dependent waterbird species were found to have increased dramatically within tissues after birds arrived in Great Salt Lake, including eared grebes (Podiceps nigricollis), common goldeneye (Bucephala clangula), and northern shovelers (Anas clypeata) 
(Conover and Vest, 2009; Vest and others, 2009). These data indicate that although the BRMB Refuge provides critical foraging habitat for nearly 1 million migratory and breeding waterbirds, it may also put birds at risk to mercury and selenium contamination. In fact, several waterbird species examined within Great Salt Lake exceeded the highest mercury concentrations ever reported for these species (Vest and others, 2009). Despite these high levels of contaminants within waterbirds using Great Salt Lake, there has been no investigation of mercury contamination in waterbirds breeding on BRMB Refuge or mercury's potential effect on avian reproduction.

\section{Objectives}

The overall objective of this study was to evaluate the risk of mercury and selenium contamination to birds breeding within Great Salt Lake, especially at BRMB Refuge, and to identify the waterbird species and areas at greatest risk to contamination. We sampled contaminants in eggs from 33 species of birds breeding within Great Salt Lake, and used eggs from a subset of these species, American avocets, black-necked stilts, white-faced ibis, Forster's terns, and marsh wrens, to focus additional studies on the effects of contaminants on reproduction. These species represent distinct foraging pathways for contaminant bioaccumulation, including aquatic insect and crustacean eaters, and fish-eating birds, and they span a range of sensitivities to mercury. White-faced ibis are considered to be highly sensitive to mercury toxicity, marsh wrens and Forster's terns are considered to be moderately sensitive to mercury toxicity, and American avocets and black-necked stilts are considered to be less sensitive to mercury toxicity (Heinz and others, 2009). Specifically, we had three main objectives:

- Objective 1: Evaluate the risk of mercury and selenium contamination to birds breeding within Great Salt Lake.

- Objective 2: Examine the spatial variation in egg mercury and selenium concentrations among wetlands of Great Salt Lake.

- Objective 3: Assess the effect of mercury on waterbird egg hatchability and nest survival at BRMB Refuge.

\section{Methods}

We conducted this study at several locations throughout Great Salt Lake, Utah, during 20102012. Our main study site was the wetlands within the BRMB Refuge (fig. 1), but we also sampled eggs throughout Great Salt Lake at Antelope Island State Park, Farmington Bay Waterfowl Management Area, Timpie Springs Wildlife Management Area, Harold S. Crane Waterfowl Management Area, Inland Sea Shorebird Reserve (and surrounding areas near Saltair), and other sites in south Great Salt Lake (fig. 2).

\section{Field Methods}

\section{Nest Monitoring and Egg Collection}

Eggs are the preferred bird tissue for assessing site-specific exposure risk of contaminants to bird reproduction, as demonstrated during this study in Great Salt Lake (Hartman and others, 2013). We sampled eggs from 33 wetland bird species that nested in Great Salt Lake (table 1). During the 2010 and 2011 nesting seasons, we visited nests only once for egg sampling and randomly selected one egg from each clutch for collection. Between April and August 2012, we monitored nests of American avocets, 
black-necked stilts, Forster's terns, white-faced ibis, and marsh wrens weekly in order to estimate nest survival for these species. During weekly visits, we uniquely marked each newly initiated nest, and recorded Universal Transverse Mercator (UTM) coordinates of each nest (Garmin ${ }^{\circledR}$ GPSMAP 76, Garmin International Inc., Olathe, Kansas). Except for marsh wrens, during each nest visit, we floated eggs to determine embryo age (Ackerman and Eagles-Smith, 2010b), recorded clutch size, determined overall nest fate (hatched, failed, abandoned, or depredated), and determined the fate of each individual egg (hatched, failed-to-hatch, abandoned, or depredated). For marsh wrens, we floated only the collected egg, and estimated the number of eggs and chicks at each visit tactilely by inserting fingers into the nest cavity.

\section{Failed-to-Hatch, Abandoned, and Random Eggs}

Elevated mercury concentrations have been found to reduce egg hatchability (Heinz and others, 2009; Herring and others, 2010; Ackerman and others, 2014). This can occur indirectly through reduced parental attentiveness and abandonment of the eggs by parents with elevated mercury levels, or directly where elevated egg mercury levels results in the failure of an embryo hatching from an otherwise successful nest where other siblings hatch. One method for assessing the potential influence of mercury on bird reproduction is comparing mercury concentrations in eggs that were abandoned, or eggs that failed to hatch, relative to eggs collected randomly from normal, active nests. To assess whether mercury concentrations in failed-to-hatch and abandoned eggs were higher than expected, we randomly collected one egg from several nests when the clutch was 6-12 days into incubation. We then followed the fate of the remaining eggs in the nest and classified the nest as successful if one or more of the remaining eggs hatched. For our random egg sample, we used only those random eggs that were collected from successful nests. We collected failed-to-hatch and naturally abandoned eggs opportunistically during routine nest monitoring. We defined failed-to-hatch eggs as those eggs that did not successfully hatch despite the fact that other sibling eggs within the clutch successfully hatched. Importantly, eggs from nests that were depredated, abandoned, or where all eggs were either infertile or dead were excluded from our definition of failed-to-hatch eggs. We defined abandoned eggs as those clutches that were naturally abandoned by their parents without any obvious sign of depredation, disturbance, or flooding. We excluded any eggs that contained signs of physical damage, such as cracks or dents in the shell because this can influence the estimated contaminant concentration for a fresh wet weight egg.

\section{Nest Survival and Surrogate Egg Technique}

To assess whether mercury concentrations influenced nest survival, we used the "surrogate egg" technique. We randomly collected one egg from a subset of nests at 6-12 days in incubation and then followed the fate of the remaining eggs in the nest, and classified the sampled nest as successful if one or more of the remaining eggs hatched. We estimated daily nest survival rates based on weekly nest visits using logistic exposure models (Shaffer, 2004). A nest was considered to have survived an interval if the clutch was still completely or partially intact, embryo development had progressed, and there were no signs of nest abandonment (such as cold eggs). A nest was considered successful if one or more eggs successfully hatched. A nest was considered unsuccessful if it was destroyed or abandoned. 
Exposure days were calculated as the number of days between nest visits (typically 7 days), except when a final nest fate occurred between visits (hatched, depredated, or abandoned). For hatched nests, we calculated exposure days for the final interval based on the expected hatch date (Ackerman and Eagles-Smith, 2010b). For depredated nests, we calculated exposure days for the final interval as the mid-point between nest visits. For abandoned nests, we calculated exposure days for the final interval as the difference between the developmental age of the eggs when the nest was abandoned (estimated via egg flotation) and the developmental age of the eggs when the nest was last visited. We censored any nests that were abandoned due to investigator disturbance at the point of abandonment.

\section{Egg Survival and Egg Micro-Sampling Technique}

To assess whether mercury concentrations influenced individual egg hatchability, we used an egg micro-sampling technique that we developed specifically for the purpose of removing a small aliquot of albumen from the egg for mercury determination, without influencing the viability of the egg (Stebbins and others, 2009). For Forster's terns, American avocets, and black-necked stilts, we microsampled albumen from one egg in a clutch from a subset of nests in 2012. A cleaned and sterilized Dremel $^{\circledR}$ tool with diamond-tipped bit was used to drill two holes in an egg, one at the air cell for venting and one at the base for albumen withdrawal. We then slowly extracted $0.20-0.30 \mathrm{~mL}$ of albumen $(<1 \%$ of the egg volume) using a 20 -gauge needle attached to a 1 -mL syringe. We then immediately sealed the extraction site and vent hole on the egg with hot-glue and cyanoacrylate. The sampled egg was then returned to the nest with the remainder of the clutch. Within each nest, one egg was designated for micro-sampling, one egg was designated a sham egg (micro-sample hole drilled in egg but no albumen was removed), and one egg was designated as a control egg (egg was handled, but not micro-sampled or drilled). Thereafter, we monitored the nest during weekly visits until the egg hatched or failed. The albumen was stored frozen at $-20^{\circ} \mathrm{C}$ until mercury determination. Mercury concentrations in albumen are highly correlated with those in the whole egg, making albumen an excellent index of egg mercury concentrations (Ackerman and Eagles-Smith, 2009; Stebbins and others, 2009).

Similar to our method of estimating daily nest survival, we estimated daily survival rates for each micro-sampled egg based on weekly visits to each nest using logistic exposure models (Shaffer, 2004). An egg was considered unsuccessful if it was destroyed or abandoned, and an egg was considered successful if it was still being incubated in the nest or hatched. Exposure days and final nest fate dates were estimated as for nest survival (see section, "Nest Survival and Surrogate Egg Technique" above).

\section{Laboratory Methods}

\section{Egg Dissection and Processing}

We stored eggs in a refrigerator until dissection. We measured length and breadth of each egg to the nearest $0.01 \mathrm{~mm}$ using digital calipers (Fowler ${ }^{\mathrm{TM}}$, Newton, Massachusetts) and measured total egg weight to the nearest $0.01 \mathrm{~g}$ on a digital balance (Ohaus ${ }^{\circledR}$ Adventurer Pro, Ohaus Corporation, Pine Brook, New Jersey). We cut an approximately $15 \mathrm{~mm}$ diameter hole in the top of each egg using clean, stainless steel scissors, and removed the embryo and any remaining contents into a sterile $30-125 \mathrm{~mL}$ jar with stainless steel forceps. We measured total egg content weight with a digital balance to the nearest $0.01 \mathrm{~g}$. We then stored the egg contents frozen at $-20^{\circ} \mathrm{C}$ until mercury determination. 


\section{Mercury Determination}

We processed and analyzed eggs for total mercury as an index of methylmercury, because $94 \%$ of the mercury in bird eggs is in the more toxic methylmercury form (Ackerman and others, 2013). We dried the entire egg contents at $50^{\circ} \mathrm{C}$ for approximately $48-72 \mathrm{~h}$ until completely dried and reweighed egg contents to determine moisture content. We then ground and homogenized the dried egg contents to a powder in a mortar and pestle, and analyzed concentrations in dry weight ( $\mathrm{dw})$. Albumen samples from micro-sampled eggs were analyzed wet, and concentrations were reported in wet weight (ww). We determined total mercury concentrations at the U.S. Geological Survey, Dixon Field Station Mercury Laboratory on a Milestone DMA-80 Direct Mercury Analyzer (Milestone, Monroe, Connecticut) or a Nippon MA-3000 Direct Mercury Analyzer (Nippon Instruments North America, College Station, Texas) following Environmental Protection Agency Method 7473 (U.S. Environmental Protection Agency, 2000), using an integrated sequence of drying, thermal decomposition, catalytic conversion, and then amalgamation, followed by atomic absorption spectroscopy. Quality assurance measures included analysis of two certified reference materials (dogfish muscle tissue [DORM], dogfish liver [DOLT], or lobster hepatopancreas [TORT] by the National Research Council of Canada, Ottawa, Canada), two system and method blanks, two continuing calibration verifications, and two duplicates per batch. Recoveries (mean \pm standard error) were $99.3 \pm 0.2 \%(\mathrm{~N}=145)$ for calibration verifications and $101.5 \pm 0.3 \%(\mathrm{~N}=129)$ for certified reference materials. Absolute relative percent difference for the duplicates was $3.2 \%(\mathrm{~N}=98)$.

\section{Selenium Determination}

Selenium concentrations were measured in a subset of eggs from 32 species (selenium concentrations were not measured in one species, common yellowthroats [Geothlypis trichas]). After an egg was dried and homogenized as described above, we sent an aliquot of the egg sample to either the Environmental Protection Agency (Region 8 Laboratory in Golden, Colorado) or Battelle Marine Sciences Laboratory (Sequim, Washington). The Environmental Protection Agency determined selenium concentrations using inductively coupled mass spectrometry (ICP-MS) based on a modification of EPA Method 200.8. Battelle Marine Sciences Laboratory determined selenium concentrations using hydride generation flow injection atomic spectroscopy (FIAS) based on a modification of EPA Method 7742 and, for a small subset of eggs, ICP-MS based on a modification of EPA Method 200.8. We used these two separate selenium determination methods because the Environmental Protection Agency generously provided free analytical analysis for a portion of the eggs, and the Environmental Protection Agency's Laboratory uses only the ICP-MS procedure. Therefore, we compared the two selenium determination methods at Battelle Marine Sciences Laboratory. To do so, we selected 10 eggs, subsampled them, and sent aliquots to Battelle Marine Sciences Laboratory for selenium determination by FIAS and ICP-MS. We found that the two methods yielded similar results (fig. 3), with the FIAS method resulting in selenium concentrations 5\% lower on average (range: $-42 \%$ to $+5 \%$ ) than the ICP-MS method. However at Battelle Marine Sciences' Laboratory, the ICP-MS method resulted in more variability less than $2.0 \mu \mathrm{g} / \mathrm{g} \mathrm{dw}$ and with a higher detection limit $(0.767 \mu \mathrm{g} / \mathrm{g}$ $\mathrm{dw})$ than the FIAS method $(0.025 \mu \mathrm{g} / \mathrm{g} \mathrm{dw})$. Therefore, we selected FIAS for further selenium determination in those eggs that were not sent to the Environmental Protection Agency's Laboratory. We also compared the same ICP-MS method at both the Environmental Protection Agency and Battelle Marine Sciences Laboratories in 10 eggs and found that the ICP-MS method at Environmental Protection Agency's Laboratory resulted in selenium concentrations 4\% higher on average (range: $-22 \%$ to $+19 \%$ ) than the ICP-MS method at Battelle Marine Sciences' Laboratory. Finally, we compared 
results for 20 eggs that were analyzed for selenium concentrations using the FIAS method at Battelle Marine Sciences' Laboratory and the ICP-MS method at Environmental Protection Agency's Laboratory. We found that the different methods at the two different laboratories yielded similar results (fig. 3), with the ICP-MS method at the Environmental Protection Agency's Laboratory resulting in selenium concentrations $7 \%$ higher on average (range: $-8 \%$ to $+18 \%$ ) than the FIAS method at Battelle Marine Sciences' Laboratory. Overall, Battelle Marine Sciences’ Laboratory determined selenium concentrations by FIAS in 196 eggs, whereas the Environmental Protection Agency's Laboratory determined selenium concentrations by ICP-MS in 410 eggs. Because the FIAS method at Battelle Marine Sciences' Laboratory and the ICP-MS method at Environmental Protection Agency's Laboratory resulted in similar concentrations, we did not adjust concentrations. The molar ratio of mercury to selenium was calculated for each egg by dividing the calculated number of moles of mercury (molar mass of mercury is $200.59 \mathrm{~g} / \mathrm{mol}$ ) within the egg by the calculated number of moles of selenium (molar mass of selenium is $78.96 \mathrm{~g} / \mathrm{mol}$ ) within the egg.

\section{Egg Contaminant Concentrations on a Fresh Wet Weight Basis}

Because eggs can lose a substantial amount of weight from the time of laying due to respiration and moisture loss, contaminant concentrations in eggs were determined on a dry weight (dw) basis and then converted into a fresh wet weight (fww) egg concentration following the methods of Ackerman and others (2013) and using the individual egg's morphological measurements. Egg contaminant concentrations on a dry weight basis were first converted to egg contaminant concentrations on a wet weight basis using an individual egg's specific moisture content. Then, egg contaminant concentrations on a wet weight basis were converted to egg contaminant concentrations on a fresh wet weight basis by dividing the total wet weight of the egg at the time of dissection by the predicted fresh wet weight of the egg at laying (see below) and multiplying that value by the egg contaminant concentration on a wet weight basis at dissection. The fresh wet weight of the egg at laying was calculated by multiplying an individual egg's volume (estimated following Hoyt, 1979) by the density of a typical freshly laid egg. Estimates for species' egg volume coefficients $\left(K_{v}\right)$ and egg densities were summarized from the literature (J.T. Ackerman, unpub. data, 2014).

\section{Statistical Methods}

\section{Mercury and Selenium in Eggs}

We natural log-transformed egg mercury and selenium concentrations prior to analysis and report back-transformed least squares means and estimate standard errors using the delta method (Seber, 1982). We used Analysis of Variance (ANOVA) to test differences in egg mercury concentrations, selenium concentrations, or molar ratios among species, and we used region and year as fixed effects. We used multiple regression to assess relationships between egg selenium concentrations and egg mercury concentrations, while accounting for species as a fixed effect. To evaluate differences in egg mercury concentrations among wetland sites, we constructed separate Analysis of Covariance (ANCOVA) models for each species and included wetland site nested within region, region, year, and nest initiation date as fixed effects. To evaluate differences in egg selenium concentrations among wetland sites, we conducted separate ANOVA models for each species and included only wetland site and year, because the subset of selenium data included fewer years and regions than the larger mercury dataset. For both the mercury and selenium models, it was necessary to exclude a variable in order for the model to converge for some species (see tables 5 and 6). 


\section{Spatial Hot Spot Analysis}

To determine hot spots where egg mercury concentrations were highest, we used the Getis-Ord $\mathrm{G}_{\mathrm{i}}{ }^{*}$ test statistic and the Hot Spot Analysis Spatial Statistics Tool in ArcMap 10.2 (Environmental Systems Research Institute, Redlands, Calif., USA). This statistic is calculated by comparing the sum of a group of points within a specific distance from one another, to the sum of all points in a given study area. The resulting z-value denotes where values significantly greater and significantly lower than the overall mean cluster spatially (Getis and Ord, 1992). We conducted a hot spot analysis for American avocet (the only species for which we had a sufficient sample size distributed throughout the study area) across the entire Great Salt Lake using a clustering distance of $5 \mathrm{~km}$. We also conducted hot spot analyses within only BRMB Refuge for 11 species using a clustering distance of $1 \mathrm{~km}$. Hot spots maps are displayed in appendix B.

\section{Effects of Mercury and Selenium on Bird Reproduction}

To test the relationship between egg contaminant concentrations and egg volume, we conducted separate multiple regression models for each species and included the egg contaminant concentration (either mercury or selenium), wetland site, year, and nest initiation date to account for the potential effects of these variables on egg volume. We tested whether failed-to-hatch eggs and abandoned eggs had higher mercury concentrations than randomly sampled eggs using ANOVA where egg mercury concentration was the dependent variable and egg type and wetland site were fixed effects and nest identification number was a random effect to statistically nest eggs within the same clutch. We then used Student's t-tests to conduct pairwise comparisons when the global model effect for egg type was significant.

For the surrogate egg and micro-sampling studies, we estimated daily survival rates based on weekly visits to each nest using logistic exposure models (Shaffer, 2004) as described above. In these models, mercury concentrations in eggs, nest age, nest age ${ }^{2}$, and nest initiation date were explanatory variables. We also used standard linear models (Zar, 1999) in the micro-sampling study to evaluate the relationships between egg fate and natural log transformed egg mercury concentrations among the drilled, control, and sham eggs. For each model, we accounted for the possible effects of wetland site and nest initiation date by including them as variables. Geometric means of egg mercury concentrations are presented within the tables for the micro-sampling data.

\section{Results and Discussion}

\section{Objective 1: Evaluate the Risk of Mercury and Selenium Contamination to Birds Breeding within Great Salt Lake}

\section{Mercury Concentrations Varied Among Species}

Mercury concentrations in eggs differed substantially among species (fig. 4), while accounting for the effects of region and year (ANOVA: species: $\mathrm{F}_{32,2498}=154.00, \mathrm{P}<0.0001$; region: $\mathrm{F}_{7,2498}=11.37$, $\mathrm{P}<0.0001$; year: $\left.\mathrm{F}_{2,2498}=28.47, \mathrm{P}<0.0001\right)$. Of the 33 bird species studied for mercury contamination, Caspian terns (Hydroprogne caspia) and Forster's terns had the highest egg mercury concentrations and Canada geese (Branta canadensis) had the lowest egg mercury concentrations. In fact, Caspian terns had mean egg mercury concentrations that were more than 131 times higher than Canada geese. Trophic level influences relative mercury concentrations, with predominantly fish-eating birds (terns) often 
having the highest mercury concentrations and herbivores (Canada geese) having among the lowest mercury concentrations. However, trophic level alone did not explain all of the variation observed in egg mercury concentrations among species. Snowy plovers had the third highest egg mercury concentrations and were 189\% higher than those in closely related killdeer (Charadrius vociferus). Similarly, black-necked stilts had the fourth highest egg mercury concentrations and were $142 \%$ higher than those in closely related American avocets. Great egrets (Ardea alba) and snowy egrets (Egretta thula) had the fifth and sixth highest egg mercury concentrations and were $115 \%$ and $94 \%$ higher than those in great-blue herons (Ardea herodias) and 73\% and 55\% higher than those in black-crowned night herons (Nycticorax nycticorax), respectively. Among songbirds, egg mercury concentrations in barn swallows (Hirundo rustica) were 19\% higher than those in cliff swallows (Petrochelidon pyrrhonota), and marsh wrens were $157 \%$ higher than yellow-headed black-birds and $41 \%$ higher than red-winged black-birds. Egg mercury concentrations in pied-billed grebes (Podilymbus podiceps) were 114\% higher than those in eared grebes and 58\% higher than those in western grebes (Aechmophorus occidentalis). Egg mercury concentrations in Franklin's gulls were 69\% higher than those in ring-billed gulls (Larus delawarensis) and 51\% higher than those in California gulls (Larus californicus). Ducks had moderate egg mercury concentrations and were 81\% higher in northern pintails (Anas acuta) than in redheads (Aythya americana). Finally, Wilson's phalarope (Phalaropus tricolor) and double-crested cormorants (Phalacrocorax auritus) were among the species at the upper range of egg mercury concentrations, whereas white-faced ibis and American coots (Fulica americana) were among the species at the lower end.

\section{Selenium Concentrations Varied Among Species}

Selenium concentrations in eggs differed substantially among species (fig. 5), while accounting for the effects of region and year (ANOVA: species: $\mathrm{F}_{31,566}=22.86, \mathrm{P}<0.0001$; region: $\mathrm{F}_{6,566}=4.85$, $\mathrm{P}<0.0001$; year: $\left.\mathrm{F}_{1,566}=65.85, \mathrm{P}<0.0001\right)$. Of the 32 bird species studied for selenium contamination, eared grebes, Forster's terns, black-crowned night herons, snowy plovers, Franklin's gulls, and redhead ducks had the highest egg selenium concentrations and Canada geese had the lowest egg selenium concentrations. Eared grebes had mean egg selenium concentrations that were 2.7 times higher than Canada geese. Eared grebes had $42 \%$ and $27 \%$ higher selenium concentrations in eggs than pied-billed grebes and western grebes, respectively. As was observed with mercury, selenium concentrations in snowy plover eggs were 58\% higher than those in killdeer. Unlike mercury, selenium concentrations in eggs of black-necked stilts and American avocets were similar. Selenium concentrations in eggs of Forster's terns were 58\% higher than those in Caspian terns. California gulls and white-faced ibis had moderate selenium concentrations in eggs. Double-crested cormorants had the third to lowest selenium concentrations in eggs among species, whereas that species was among the highest in egg mercury concentrations.

\section{Molar Ratio of Mercury to Selenium Among Species}

Using log transformed egg mercury and selenium concentrations for each individual egg, we found that egg selenium concentrations were correlated with egg mercury concentrations while accounting for the main effect of species in the model but without an interaction term (fig. 6; Multiple

Regression: $\mathrm{N}=606$ eggs, $\mathrm{R}^{2}=0.55$; mercury: $\mathrm{F}_{1,573}=24.16, \mathrm{P}<0.0001$; species: $\mathrm{F}_{31,573}=20.76, \mathrm{P}<0.0001$ ). Because we were unable to include a species $\times$ mercury interaction term, we performed separate linear regressions for each species and found that only 6 out of 29 species had significant positive correlations between selenium and mercury concentrations in individual eggs (table 2 ). These positive correlations 
occurred in black-necked stilts $\left(\mathrm{R}^{2}=0.14\right)$, California gulls $\left(\mathrm{R}^{2}=0.17\right)$, cliff swallows $\left(\mathrm{R}^{2}=0.47\right)$, Franklin's gulls $\left(\mathrm{R}^{2}=0.29\right)$, great blue herons $\left(\mathrm{R}^{2}=0.23\right)$, and marsh wrens $\left(\mathrm{R}^{2}=0.48\right)$. Lastly, we used untransformed mean egg mercury and selenium concentrations for each species and found that mean egg selenium concentrations were not correlated with mean egg mercury concentrations among species (fig. 7; Linear Regression: $\mathrm{N}=32$ species, $\mathrm{R}^{2}=0.05, \mathrm{P}=0.23$ ). However, when we exclude Caspian terns from this analysis, then mean egg selenium concentrations were correlated with mean egg mercury concentrations among species (Linear Regression: $\mathrm{N}=31$ species, $\mathrm{R}^{2}=0.20, \mathrm{P}=0.01$ ). These data indicate that while selenium concentrations sometimes increased with mercury concentrations in eggs within and across species, most of the relationships were weak.

Molar ratios of mercury to selenium in eggs differed substantially among species (fig. 8), while accounting for the effects of region and year (ANOVA: species: $\mathrm{F}_{31,566}=39.24, \mathrm{P}<0.0001$; region: $\mathrm{F}_{6,566}=2.31, \mathrm{P}=0.03$; year: $\mathrm{F}_{1,566}=3.82, \mathrm{P}=0.05$ ). Of the 32 bird species studied for molar ratios, Caspian terns, Forster's terns, and snowy plovers had the highest molar ratios of mercury to selenium in eggs, and Canada geese had the lowest molar ratios. All mean mercury to selenium molar ratios among species were less than 1.0. Additionally, all individual egg's mercury to selenium molar ratios were less than 1.0, except for two individual Caspian tern eggs where the mercury to selenium molar ratio was 1.0 and 1.1. Thus, based on the molar ratio, there was an excess of selenium to mercury in almost all bird eggs. We also present the molar ratios of selenium to mercury in eggs among species for reference (fig. 8).

\section{Mercury and Selenium Risk to Birds}

Mercury and selenium concentrations in eggs of birds breeding in Great Salt Lake were considered moderate to high. For example, least-square mean egg mercury concentrations were $0.87 \pm 0.09 \mu \mathrm{g} / \mathrm{g}$ fww for Caspian terns, $0.64 \pm 0.05 \mu \mathrm{g} / \mathrm{g}$ fww for Forster's terns, $0.30 \pm 0.02 \mu \mathrm{g} / \mathrm{g}$ fww for stilts, and $0.12 \pm 0.01 \mu \mathrm{g} / \mathrm{g}$ fww for avocets in Great Salt Lake (fig. 4). These egg mercury concentrations can be directly compared to the same species in the highly contaminated San Francisco Bay Estuary, where geometric mean egg total mercury concentrations were $0.75 \pm 0.09 \mu \mathrm{g} / \mathrm{g}$ fww for Caspian terns, $1.47 \pm 0.05 \mu \mathrm{g} / \mathrm{g}$ fww for Forster's terns, $0.66 \pm 0.04 \mu \mathrm{g} / \mathrm{g}$ fww for stilts, and $0.22 \pm 0.01 \mu \mathrm{g} / \mathrm{g}$ fww for avocets (Ackerman and others, 2014). Thus, compared to the San Francisco Bay Estuary, eggs in Great Salt Lake were approximately 16\% higher in Caspian terns, 56\% lower in Forster's terns, 55\% lower in black-necked stilts, and 45\% lower in American avocets. The majority of eggs in Great Salt Lake were sampled at BRMB Refuge, which we showed (below) had among the lowest egg mercury concentrations sampled within Great Salt Lake.

Table 3 details the percentage of eggs sampled that exceeded various toxicity levels, and table 4 gives each species means \pm standard errors. Because the sensitivity of birds to mercury and selenium toxicity can differ widely among species (Heinz and others, 2009; Ohlendorf and Heinz, 2011), it is difficult to compare egg mercury and selenium concentrations against known toxicity thresholds. Therefore, we have provided several toxicity benchmarks in eggs that have been suggested to impair bird reproduction. For songbirds, we found that $52 \%$ of barn swallows, $50 \%$ of common yellowthroats, $37 \%$ of cliff swallows, $18 \%$ of marsh wrens, $2 \%$ of yellow-headed black birds, $0 \%$ of brown-headed cowbirds (Molothrus ater), and $0 \%$ of red-winged black birds exceeded $0.11 \mu \mathrm{g} / \mathrm{g}$ fww, which is a benchmark in eggs that has been suggested to reduce nest success by $10 \%$ in songbirds (Jackson and others, 2011). Similarly, $86 \%$ of Caspian terns, 35\% of Forster's terns, $6 \%$ of black-necked stilts, and $0 \%$ of American avocets, exceeded $0.65 \mu \mathrm{g} / \mathrm{g}$ fww in eggs, which is equivalent to mercury concentrations in parent's internal organs which is known to induce methylmercury demethylation in the livers of these four species (Eagles-Smith and others, 2009b; Ackerman and others, 2014). Although 
injected mercury is more toxic to embryos than naturally derived mercury, Heinz and others (2009) showed that ibis, herons, and egrets are among the most sensitive species to mercury toxicity and that their $\mathrm{LC}_{50} \mathrm{~s}$ were less than $0.25 \mu \mathrm{g} / \mathrm{g}$ fww. Using this value, we found that $50 \%$ of great egrets, $40 \%$ of snowy egrets, $12 \%$ of black-crowned night herons, $8 \%$ of great blue herons, and $2 \%$ of white-faced ibis exceeded $0.25 \mu \mathrm{g} / \mathrm{g}$ fww. Ducks are thought to be less sensitive to mercury toxicity, and a toxicity threshold of $0.5 \mu \mathrm{g} / \mathrm{g}$ fww to $1.0 \mu \mathrm{g} / \mathrm{g}$ fww is commonly used for these species (Heinz and others, 2009). No eggs of ducks or geese exceeded $0.5 \mu \mathrm{g} / \mathrm{g}$ fww. Other species with less-defined toxicity thresholds but that had mercury concentrations in eggs more than $0.5 \mu \mathrm{g} / \mathrm{g}$ fww included $20 \%$ of snowy plovers, $6 \%$ of double-crested cormorants, $2 \%$ of pied-billed grebes, and $1 \%$ of American coots. Therefore, a substantial percentage of eggs sampled had mercury concentrations greater than common toxicity thresholds indicating that mercury could be impairing bird reproduction in Great Salt Lake and that this may be considered an area of conservation concern that warrants close monitoring.

There were fewer eggs that exceeded toxicity levels for selenium (table 3). Selenium concentrations in eggs greater than $5.0 \mu \mathrm{g} / \mathrm{g} \mathrm{dw}$ is a level that exceeds the normal range of egg values (Ohlendorf and Heinz, 2011). This level is recommended as a "No Effect Concentration" for bird eggs (J. Skorupa, U.S. Fish and Wildlife Service, written commun., 2014), and also is at a level that would begin to trigger a regulatory response by the Utah Department of Natural Resources, Division of Water Quality in the Gilbert Bay area of Great Salt Lake. A level greater than $5.0 \mu \mathrm{g} / \mathrm{g} \mathrm{dw}$ would result in "increased monitoring to address data gaps, loadings, and areas of uncertainty identified from initial Great Salt Lake selenium studies" (Utah Administrative Code - UAC R317-2-14; http://www.rules.utah.gov/publicat/code/r317/r317-002.htm\#T16; their table 2.14.2, footnote 14). Additionally, $6.4 \mu \mathrm{g} / \mathrm{g} \mathrm{dw}$ is a level that is approaching reproductive impairment (Ohlendorf and Heinz, 2011) and would trigger "initiation of a Level II Anti-degradation review by the State for all discharge permit renewals or new discharge permits to Great Salt Lake" by the Utah Department of Natural Resources, Division of Water Quality in the Gilbert Bay area of Great Salt Lake (Utah Administrative Code - UAC R317-2-14; http://www.rules.utah.gov/publicat/code/r317/r317-002.htm\#T16; their table 2.14.2, footnote 14). Contaminant concentrations in bird eggs should be reported in fresh wet weight (fww), rather than dry weight (dw), due to moisture loss and embryo respiration during development (Ackerman and others, 2013). Therefore, we converted $5.0 \mu \mathrm{g} / \mathrm{g}$ dw to $1.10 \mu \mathrm{g} / \mathrm{g}$ fww and converted 6.4 $\mu \mathrm{g} / \mathrm{g}$ dw to $1.41 \mu \mathrm{g} / \mathrm{g}$ fww using an average percent moisture of $77.91 \%$ in eggs sampled in Great Salt Lake during this study. We also binned selenium levels for reporting results in figures using $2.5 \mu \mathrm{g} / \mathrm{g} \mathrm{dw}$ $(0.55 \mu \mathrm{g} / \mathrm{g}$ fww using an average percent moisture of $77.91 \%)$, which is the higher end of the range typically observed for wild bird eggs (Ohlendorf and Heinz, 2011). Only eared grebe and black-crowned night heron eggs exceeded $1.41 \mu \mathrm{g} / \mathrm{g}$ fww (about $6.4 \mu \mathrm{g} / \mathrm{g} \mathrm{dw}$ ), with one egg of each species exceeding this level. Additionally, $46 \%$ of eared grebe, $20 \%$ of snowy plover, $19 \%$ of black-crowned night heron, $17 \%$ of redhead, $14 \%$ of Forster's tern, $10 \%$ of American avocet, $10 \%$ of Franklin's gull, $4 \%$ of California gull, and 3\% of black-necked stilt eggs exceeded $1.1 \mu \mathrm{g} / \mathrm{g}$ fww (about $5.0 \mu \mathrm{g} / \mathrm{g} \mathrm{dw}$ ). Most eggs of the majority of species exceeded selenium concentrations of $0.55 \mu \mathrm{g} / \mathrm{g}$ fww (about $2.5 \mu \mathrm{g} / \mathrm{g} \mathrm{dw}$ ), indicating that bird eggs in Great Salt Lake exceed the higher end of the range typically observed in wild bird eggs. The fact that 9 of 32 species had eggs exceeding the level that would begin to trigger a regulatory response by the Utah Department of Natural Resources, Division of Water Quality in the Gilbert Bay area of Great Salt Lake, and two species had egg selenium concentrations exceeding the second-level trigger, suggests that selenium concentrations in birds warrants further study. 


\section{Objective 2: Examine the Spatial Variation in Egg Mercury and Selenium Concentrations among Wetlands of Great Salt Lake}

\section{Mercury Concentrations Varied Among Wetland Sites}

As shown above in the global species model, mercury concentrations in eggs differed among regions (ANOVA: species: $\mathrm{F}_{32,2498}=154.00, \mathrm{P}<0.0001$; region: $\mathrm{F}_{7,2498}=11.37, \mathrm{P}<0.0001$; year:

$\left.\mathrm{F}_{2,2498}=28.47, \mathrm{P}<0.0001\right)$. Because not all species were sampled at each site, we were unable to include a site $\times$ species interaction in a global model for site. We therefore conducted separate statistical models for each species.

Mercury concentrations in eggs differed among wetland sites in 8 of the 25 bird species, and differed among regions in 7 of the 12 bird species where we could test these effects (table 5). Mercury concentrations tended to be lower at the BRMB Refuge than at other areas throughout Great Salt Lake (figs. 9-21; see also appendix A, figs. A1-A41). In particular, mercury concentrations in eggs collected near Antelope Island and Farmington Bay were consistently higher than all other regions, especially BRMB Refuge. We were able to collect eggs at multiple regions of Great Salt Lake for 12 species (American avocets, American coots, barn swallow, black-necked stilts, California gulls, cinnamon teal (Anas cyanoptera), double-crested cormorant, great blue heron, killdeer, mallard (Anas platyrhynchos), marsh wrens, and yellow-headed black bird) and all but cinnamon teal, double-crested cormorant, great blue heron, killdeer, and mallard differed significantly in their egg mercury concentrations among regions (table 5). Mercury concentrations in American avocet eggs were highest at BRMB Refuge wetland levee 5B/5C, followed by Farmington Bay, Timpie Springs, BRMB Refuge wetland 5C, Antelope Island, 12 other wetlands at BRMB Refuge Refuge, Inland Sea Shorebird Reserve, and then 4 other wetlands at BRMB Refuge (fig. 9). Mercury concentrations in American coot eggs were highest at BRMB Refuge wetland 3B, followed by Farmington Bay, 5 other wetlands at BRMB Refuge, Inland Sea Shorebird Reserve, and then 13 other wetlands at BRMB Refuge (fig. 10). Mercury concentrations in black-necked stilt eggs were highest at Farmington Bay, followed by BRMB Refuge wetland 1GSL, Inland Sea Shorebird Reserve, Antelope Island, 7 other wetlands at BRMB Refuge, Timpie Springs, and then 4 other wetlands at BRMB Refuge (fig. 11). Mercury concentrations in California gull eggs were highest at South Great Salt Lake at I-80, followed by Antelope Island, and then four other wetlands at BRMB Refuge (fig. 12). Mercury concentrations in marsh wren (Cistothorus palustris) eggs were highest at Farmington Bay, followed by Inland Sea Shorebird Reserve, 16 other wetlands at BRMB Refuge, Harold Crane, and then 2 other wetlands at BRMB Refuge (fig. 17). Mercury concentrations in yellow-headed black bird eggs were highest at Antelope Island, followed by 17 other wetlands at BRMB Refuge, South Great Salt Lake at I-80, and then 1 other wetland at BRMB Refuge (fig. 21).

Within BRMB Refuge, eggs collected near Wetland Complex 3 tended to have the highest mercury concentrations. For example, mercury concentrations in eggs were highest for American coots in 3B and 3E (fig. 10), for Franklin's gulls in 3K (fig. 15), for redheads in 3D (fig. 19), for white-faced ibis in 3B (but not significant; fig. 20), and for yellow-headed black birds in 3E (fig. 21). Wetland 5C had the highest mercury concentrations in eggs of American avocets (fig. 9) and Forster's terns (fig. 14), followed by several wetlands in Wetland Complex 3. For songbirds, mercury concentrations in eggs collected in 8GSL were typically the highest of any other wetland sampled at BRMB Refuge. Mercury concentrations were higher in 8GSL for cliff swallows than the 13 other wetlands sampled at BRMB Refuge for that species (fig. 13), higher in 8GSL for marsh wrens than the 17 other wetlands sampled at BRMB Refuge for that species (fig. 17; see also Hartman and others, 2013), and second highest in 8GSL for yellow-headed black birds than the 16 other wetlands sampled at BRMB Refuge for that species (fig. 21). Wetlands within Wetland Complex 3 tended to have the next highest mercury 
concentrations for songbird eggs, especially 3E and 3B. Figures 9-21 depict mercury concentrations in eggs for 13 of the primary species by wetland site, and maps (appendix A: figs. A1-A41) depict mercury concentrations for all species, and hot spot maps depict egg concentrations higher and lower than the overall mean for that species (appendix B: figs. B1-B12). It is important to note that some birds travel far-distances from their breeding colonies to forage, such as gulls, ibis, cormorants, herons, and egrets. Therefore, any wetland-specific differences in egg mercury concentrations may not indicate local mercury exposure, and the regional comparisons might be more meaningful for these species.

Mercury concentrations in eggs also differed among years in 7 of 23 bird species and with date in 5 of 25 bird species (table 5). Mercury concentrations were lowest in 2012, and generally similar between 2010 and 2011. On average, mercury concentrations in eggs were 53\% and 60\% lower in American avocets, 35\% and 30\% lower in black-necked stilts, $46 \%$ higher and 14\% lower in Forster's terns, $21 \%$ and $15 \%$ lower in marsh wrens, $24 \%$ and $27 \%$ lower in white-faced ibis, and $34 \%$ and $36 \%$ lower in yellow-headed black birds in 2012 compared to 2010 and 2011 . Climate-related variables, particularly flooding and wetting and drying of wetland habitats, may have contributed to among-year variability in egg mercury concentrations, and might be detectable with a longer time series of egg mercury concentrations over several additional years. Mercury concentrations in eggs increased with nest initiation date for each of the five species where date influenced concentrations.

\section{Selenium Concentrations Varied Among Wetland Sites}

As shown above in the global species model, selenium concentrations in eggs differed among regions (ANOVA: species: $\mathrm{F}_{31,566}=22.86, \mathrm{P}<0.0001$; region: $\mathrm{F}_{6,566}=4.85, \mathrm{P}<0.0001$; year: $\mathrm{F}_{1,566}=65.85$, $\mathrm{P}<0.0001)$. Selenium concentrations in eggs differed among wetland sites in 6 of the 22 bird species for which we could test the effect of site (table 6; figs. 22-31). As with mercury, selenium concentrations in eggs of American avocets were highest in 5C (fig. 22). For black-necked stilts (fig. 23) and Forster's terns (fig. 25), selenium concentrations were highest in 1GSL. For marsh wrens, selenium concentrations were highest in Farmington Bay, followed by 8GSL at BRMB Refuge, Inland Sea Shorebird Reserve, 3K at BRMB Refuge, Harold Crane, and 3J at BRMB Refuge (fig. 27). For Franklin's gulls, selenium concentrations in eggs were highest in 3B and 1GSL (fig. 26). For redhead, selenium concentrations in eggs were highest in 3E/4B, 3B, and 1GSL (fig. 29). Although not statistically significant, selenium concentrations in eggs of California gulls tended to be higher at South Great Salt Lake at I-80 and Antelope Island than at wetland sites within BRMB Refuge (fig. 24). Figures 22-31 depict selenium concentrations in eggs for 10 of the primary species by wetland site, and maps (appendix C, figs. C1-C36) depict selenium concentrations for all species.

Selenium concentrations in eggs also differed among years in 6 of the 20 bird species where we could test the effect of year (table 6). Selenium concentrations were higher in 2010 than in 2011 (we did not test selenium concentrations in any eggs sampled during 2012). On average, selenium concentrations in eggs were $60 \%$ higher in mallard, $50 \%$ higher in snowy plovers, $45 \%$ higher in piedbilled grebes, 38\% higher in Caspian terns, 22\% higher in great-blue herons, 18\% higher in Franklin's gulls, and 29\% lower in pied-billed grebes in 2010 compared to 2011. Although not statistically significant, the same trend of higher egg selenium concentrations in 2010 compared to 2011 was observed in most of the other species as well (for example, 9\% higher in California gulls). 


\section{Objective 3: Assess the Effect of Mercury on Waterbird Egg Hatchability and Nest Survival at Bear River Migratory Bird Refuge}

Mercury can potentially influence bird reproduction in several ways, including altered parental behavior, embryo mortality, hatching failure, and reduced chick growth, health, and survival. In this study, we focused on the potential influence of mercury on egg hatchability and nest survival by (1) comparing mercury concentrations in randomly sampled eggs to mercury concentrations in failed to hatch eggs and abandoned eggs, (2) examining the influence of mercury concentrations in surrogate eggs on the fate of the remaining eggs in the clutch, and (3) investigating the influence of mercury concentrations in micro-sampled eggs to the fate of all eggs in the clutch. Additionally, we examined the relationship between egg contaminant concentrations and egg volume.

\section{Mercury and Selenium Concentrations Versus Egg Volume}

Egg volume was negatively correlated with log transformed mercury concentrations in 5 of the 28 bird species with adequate sample sizes, while statistically accounting for the potential effects of wetland site, year, and nest initiation date (table 7). In particular, egg volume decreased with mercury concentrations in snowy plovers, gadwall (Anas strepera), black-necked stilts, and Forster's terns, and increased in black-crowned night herons (fig. 32). Over the observed range of egg mercury concentrations (low to high), our models estimated a decrease in egg volume by $57 \%$ for gadwall, $27 \%$ for snowy plovers, 15\% for black-necked stilts, and 9\% for Forster's terns, as well as an increase of $31 \%$ for black-crowned night herons. Over the central span of the observed range of egg mercury concentrations (10th to 90th percentile of egg mercury concentrations), our models estimated a decrease in egg volume by $20 \%$ for gadwall, $9 \%$ for snowy plovers, $5 \%$ for black-necked stilts, and $3 \%$ for Forster's terns, as well as an increase of $11 \%$ for black-crowned night herons.

Egg volume was negatively correlated with log transformed selenium concentrations in 3 of the 25 bird species with adequate sample sizes, while statistically accounting for the potential effects of wetland site, year, and nest initiation date (table 8). In particular, egg volume decreased with selenium concentrations in American coots, eared grebes, and Forster's terns (all species in fig. 33). Over the observed range of egg selenium concentrations (low to high), our models estimated a decrease in egg volume by $17 \%$ for American coots, $15 \%$ for Forster's terns, and 10\% for eared grebes. Over the central span of the observed range of egg selenium concentrations (10th to 90th percentile), our models estimated a decrease in egg volume by $10 \%$ for American coots, $9 \%$ for Forster's terns, and $6 \%$ for eared grebes.

Other studies have also found a negative correlation between egg volume and mercury concentrations (Evers and others, 2003; Hargreaves and others, 2011). For example, parents exposed to higher concentrations of mercury might have lower body condition (Ackerman and others, 2012) and, in turn, might lay smaller eggs. However, the negative correlation between egg volume and mercury concentrations is correlational and may not be causal. The fact that we also found a positive correlation between egg volume and mercury concentrations in one species suggests that the mechanisms driving these relationships are unclear and likely complex. Alternatively, it may be that egg size can influence contaminant concentrations. Specifically, if the total burden of mercury or selenium deposited into an egg is rather constant on a per-egg basis, then the contaminant concentration could be driven by egg size via dilution in larger eggs and concentration in smaller eggs. Further study would be needed to evaluate whether the negative relationship between egg volume and mercury concentrations observed at Great Salt Lake and elsewhere are indicative of actual reproductive impairment or an inherent correlation. 


\section{Mercury Concentrations in Random Eggs Versus Failed-to-Hatch Eggs and Abandoned Eggs}

During our nest monitoring activities, we identified and salvaged eggs that failed to hatch in otherwise successful nests (that is, lone or more eggs hatched) and eggs that were abandoned by parents for natural reasons. We also collected viable eggs randomly from active nests. Including salvaged eggs, we sampled mercury concentrations in 78 American avocet, 106 black-necked stilt, 98 Forster's tern, 45 marsh wren, and 95 white-faced ibis eggs.

American Avocets.-Mercury concentrations in American avocet eggs did not differ among random eggs from successful nests $(0.07 \pm 0.01 \mu \mathrm{g} / \mathrm{g}$ fww $)$, naturally abandoned eggs $(0.06 \pm 0.01 \mu \mathrm{g} / \mathrm{g}$ fww), and failed-to-hatch eggs $(0.06 \pm 0.01 \mu \mathrm{g} / \mathrm{g}$ fww $)$ after accounting for the effects of colony site and including nest number as a random effect (fig. 34; ANOVA: egg type: $\mathrm{F}_{2,34.66}=2.58, \mathrm{P}=0.09$; site: $\left.\mathrm{F}_{2,59.43}=0.36, \mathrm{P}=0.70\right)$.

Black-Necked Stilts.-Mercury concentrations in black-necked stilt eggs did not differ among random eggs from successful nests $(0.25 \pm 0.02 \mu \mathrm{g} / \mathrm{g}$ fww $)$, naturally abandoned eggs $(0.26 \pm 0.05 \mu \mathrm{g} / \mathrm{g}$ fww), and failed-to-hatch eggs $(0.29 \pm 0.04 \mu \mathrm{g} / \mathrm{g}$ fww $)$ after accounting for the effects of colony site and including nest number as a random effect (fig. 34; ANOVA: egg type: $\mathrm{F}_{2,36.69}=0.70, \mathrm{P}=0.50$; site: $\left.\mathrm{F}_{2,89.37}=0.46, \mathrm{P}=0.63\right)$.

Forster's Terns.-Mercury concentrations in Forster's tern eggs differed among random eggs from successful nests $(0.50 \pm 0.06 \mu \mathrm{g} / \mathrm{g}$ fww $)$, naturally abandoned eggs $(0.38 \pm 0.06 \mu \mathrm{g} / \mathrm{g}$ fww $)$, and failed-to-hatch eggs $(0.53 \pm 0.09 \mu \mathrm{g} / \mathrm{g}$ fww $)$ after accounting for the effects of colony site and including nest number as a random effect (fig. 34; ANOVA: egg type: $\mathrm{F}_{2,81.01}=3.07$, $\mathrm{P}=0.05$; site: $\mathrm{F}_{4,81.93}=2.47$, $\mathrm{P}=0.05$ ). However, only abandoned eggs were significantly lower than both failed-to-hatch and random eggs (Student's $t$-test: $\mathrm{P}<0.05$ ), which did not differ from each other (Student's $t$-test: $\mathrm{P}>0.05$ ). Although we found no effects of mercury on Forster's terns in Great Salt Lake, at higher mercury concentrations in San Francisco Bay Estuary we found that mercury concentrations in Forster's tern eggs were 28 percent higher in failed-to-hatch eggs $(1.84 \pm 0.16 \mu \mathrm{g} / \mathrm{g}$ fww) than in randomly sampled eggs from successful nests $(1.44 \pm 0.09 \mu \mathrm{g} / \mathrm{g}$ fww; Ackerman and others, 2014), suggesting Forster's terns may still be less than the threshold for significant reproductive impairment in Great Salt Lake.

Marsh Wrens.- Mercury concentrations in marsh wren eggs differed among random eggs from successful nests, naturally abandoned eggs, and failed-to-hatch eggs, after statistically accounting for the effects of colony site and including nest number as a random effect (fig. 34; ANOVA: egg type: $\mathrm{F}_{2,1.15}=217.92, \mathrm{P}=0.03$; site: $\mathrm{F}_{5,36.01}=3.06, \mathrm{P}=0.02$ ). On average, mercury concentrations were 152 percent higher in abandoned eggs $(0.20 \pm 0.07 \mu \mathrm{g} / \mathrm{g}$ fww $)$ and 14 percent higher in failed-to-hatch eggs $(0.09 \pm 0.01 \mu \mathrm{g} / \mathrm{g}$ fww $)$ than in randomly sampled eggs from successful nests $(0.08 \pm 0.01 \mu \mathrm{g} / \mathrm{g}$ fww; Student's $t$-tests: all $\mathrm{P}<0.05)$. Sample size for naturally occurring abandoned and failed-to-hatch eggs was small $(\mathrm{N}=6)$. However, two other wren studies, also with small sample sizes for failed eggs, found that marsh wrens had higher mercury concentrations in failed eggs $(0.29 \mu \mathrm{g} / \mathrm{g} \mathrm{ww})$ than in randomly sampled eggs $(0.18 \mu \mathrm{g} / \mathrm{g}$ ww; Tsipoura and others, 2008), and Carolina wrens had a $10 \%$ decrease in nest success at $0.11 \mu \mathrm{g} / \mathrm{g}$ ww in eggs (Jackson and others, 2011). Together, our study with the two published studies suggests that wrens may be vulnerable to mercury exposure, and that wren mercury concentrations in Great Salt Lake appear to be high enough to cause hatch failure. 
White-Faced Ibis. - Mercury concentrations in white-faced ibis eggs differed among random eggs from successful nests, naturally abandoned eggs, and failed-to-hatch eggs, after statistically accounting for the effects of colony site and including nest number as a random effect (fig. 34; ANOVA: egg type: $\mathrm{F}_{2,19.56}=4.21, \mathrm{P}=0.03$; site: $\left.\mathrm{F}_{1,83.09}=3.48, \mathrm{P}=0.07\right)$. On average, mercury concentrations were 74 percent higher in abandoned eggs $(0.10 \pm 0.02 \mu \mathrm{g} / \mathrm{g}$ fww $)$ than in randomly sampled eggs from successful nests $(0.06 \pm 0.01 \mu \mathrm{g} / \mathrm{g}$ fww; Student's $t$-tests: $\mathrm{P}<0.05)$, but failed-to-hatch eggs $(0.06 \pm 0.01 \mu \mathrm{g} / \mathrm{g}$ fww) did not differ from random eggs (Student's $t$-test: $\mathrm{P}>0.05)$. Heinz and others (2009) found that the related white ibis was particularly sensitive to methylmercury injected into eggs, and estimated an $\mathrm{LC}_{50}$ of $0.12 \mu \mathrm{g} / \mathrm{g} \mathrm{ww}$. Although the egg mercury concentrations in white-faced ibis appear to be quite low in Great Salt Lake, the levels are similar to the $\mathrm{LC}_{50}$ found by Heinz and others (2009) for egg hatching success, indicating that white-faced ibis parents may actually be abandoning nests when they are exposed to higher concentrations of mercury.

\section{Effects of Mercury Concentrations on Nest Survival: Surrogate Egg Method}

We found no effect of the surrogate egg's mercury concentration on nest survival of the remaining clutch in any species, as detailed below for each species. These studies occurred in 2012 which, we later learned, had substantially lower mercury concentrations in eggs than in 2010 or 2011, as detailed above.

American Avocets.-There was no effect of the surrogate egg's mercury concentration on nest survival of the remaining clutch in American avocets after statistically accounting for site, nest initiation date, and nest age (Generalized Linear Model: THg concentration: $z$-value $=-1.13, \mathrm{P}=0.26$; site: $z$ value $=0.16, \mathrm{P}=0.87$; nest age: $z$-value $=-1.80, \mathrm{P}=0.07$; nest age ${ }^{2}: z$-value $=1.49, \mathrm{P}=0.14$; nest initiation date: $z$-value $=-0.17, \mathrm{P}=0.86$ ). A total of 68 avocet nests and 1,168 exposure days were used in this analyses.

Black-Necked Stilts. - There was no effect of the surrogate egg's mercury concentration on nest survival of the remaining clutch in black-necked stilts after statistically accounting for site, nest initiation date, and nest age (Generalized Linear Model: THg concentration: $z$-value $=1.43, \mathrm{P}=0.15$; site: $z$-value $=0.93, \mathrm{P}=0.35$; nest age: $z$-value $=-3.08, \mathrm{P}<0.01$; nest age ${ }^{2}: z$-value $=2.73, \mathrm{P}<0.01$; nest initiation date: $z$-value $=-1.37, \mathrm{P}=0.17)$. A total of 117 stilt nests and 1,831 exposure days were used in this analyses.

Forster's Terns.- There was no effect of the surrogate egg's mercury concentration on nest survival of the remaining clutch in Forster's terns after statistically accounting for site, nest initiation date, and nest age (Generalized Linear Model: THg concentration: $z$-value $=1.29, \mathrm{P}=0.20$; site: $z$ value $=4.83, \mathrm{P}<0.01$; nest age: $z$-value $=-2.43, \mathrm{P}=0.02$; nest age ${ }^{2}: z$-value $=1.42, \mathrm{P}=0.16$; nest initiation date: $z$-value $=-2.33, \mathrm{P}=0.02$ ). A total of 88 tern nests and 1,511 exposure days were used in this analyses.

Marsh Wrens.-There was no effect of the surrogate egg's mercury concentration on nest survival of the remaining clutch in marsh wrens after statistically accounting for site (Generalized Linear Model: THg concentration: $z$-value $=1.26, \mathrm{P}=0.21$; site: $z$-value $=2.08, \mathrm{P}=0.04)$. A total of 166 wren nests and 2,779 exposure days were used in this analysis.

White-Faced Ibis.-There was no effect of the surrogate egg's mercury concentration on nest survival of the remaining clutch in white-faced ibis after statistically accounting for site, nest initiation date, and nest age (Generalized Linear Model: THg concentration: $z$-value $=1.78, \mathrm{P}=0.07$; site: $z$ value $=1.67, \mathrm{P}=0.09$; nest age: $z$-value $=-3.17, \mathrm{P}<0.01$; nest age ${ }^{2}: z$-value $=1.68, \mathrm{P}=0.09$; nest initiation date: $z$-value $=-0.10, \mathrm{P}=0.92$ ). A total of 160 ibis nests and 2,321 exposure days were used in this analysis. 


\section{Effects of Mercury Concentrations on Nest Survival: Micro-Sampled Egg Method}

As with the surrogate egg technique, we found no effect of the micro-sampled egg's mercury concentration on nest survival in any species, as detailed below for each species. These studies occurred in 2012, which (we later learned) had substantially lower mercury concentrations in eggs than in 2010 or 2011, as detailed above.

Forster's Terns. - There was no effect of the micro-sampled egg's mercury concentration on nest survival of the full clutch in Forster's terns after statistically accounting for site, nest initiation date, and nest age (Generalized Linear Model: albumen THg concentration: $z$-value $=-0.23, \mathrm{P}=0.82$; site: $z$ value $=0.84, \mathrm{P}=0.40$; nest age: $z$-value $=1.31, \mathrm{P}=0.19$; nest age $\mathrm{e}^{2}: z$-value $=-1.79, \mathrm{P}=0.07$; nest initiation date: $z$-value $=-0.89, \mathrm{P}=0.37$ ). A total of 20 tern nests and 417 exposure days were used in this analyses. Out of the 21 Forster's tern eggs that were micro-sampled, 9 failed, whereas 9 of the eggs designated as the sham egg and 16 of the eggs designated as the control egg from the same nest failed (table 9). After accounting for possible effects of site and nest initiation date, mercury concentrations in albumen from micro-sampled eggs that hatched were not different than concentrations in albumen from micro-sampled eggs that failed (hatched eggs: $0.88 \pm 0.25 \mu \mathrm{g} / \mathrm{g} \mathrm{ww}$; failed eggs: $0.55 \pm 0.22 \mu \mathrm{g} / \mathrm{g} \mathrm{ww} ; \mathrm{P}=0.28$ ), nor was there any difference in mercury concentrations in albumen from micro-sampled eggs from nests that hatched all eggs $(\mathrm{N}=7 ; 0.84 \pm 0.32 \mu \mathrm{g} / \mathrm{g} w \mathrm{w})$, hatched only some eggs $(\mathrm{N}=7 ; 0.73 \pm 0.29 \mu \mathrm{g} / \mathrm{g} w \mathrm{w})$, were fully depredated or destroyed $(\mathrm{N}=2 ; 0.27 \pm 0.18 \mu \mathrm{g} / \mathrm{g} \mathrm{ww})$, or abandoned $(\mathrm{N}=4 ; 0.83 \pm 0.28 \mu \mathrm{g} / \mathrm{g} \mathrm{ww}$; table 10). After accounting for possible effects of wetland site and nest initiation date, mercury concentrations in albumen of micro-sampled eggs did not differ among the possible combinations of fates of both control and micro-sampled eggs $\left(\mathrm{F}_{3,12}=0.38, \mathrm{P}=0.76\right.$; table 11)

American Avocets.- There was no effect of the micro-sampled egg's mercury concentration on nest survival of the full clutch in American avocets after statistically accounting for site, nest initiation date, and nest age (Generalized Linear Model: albumen THg concentration: $z$-value $=1.35, \mathrm{P}=0.18$; site: $z$-value $=-3.06, \mathrm{P}<0.01$; nest age: $z$-value $=-1.43, \mathrm{P}=0.15$; nest age $\mathrm{e}^{2}: z$-value $=0.79, \mathrm{P}=0.43$; nest initiation date: $z$-value $=-3.39, \mathrm{P}<0.01)$. A total of 24 American avocet nests and 436 exposure days were used in this analyses. Out of the 24 American avocet eggs that were micro-sampled, 14 failed, whereas 14 of the eggs designated as the sham egg and 15 of the eggs designated as the control egg from the same nest failed (table 9). After accounting for possible effects of site and nest initiation date, mercury concentrations in albumen from micro-sampled eggs that hatched were not different than concentrations in albumen from micro-sampled eggs that failed (hatched eggs: $0.10 \pm 0.02 \mu \mathrm{g} / \mathrm{g} \mathrm{ww}$; failed eggs: $0.07 \pm 0.02 \mu \mathrm{g} / \mathrm{g} \mathrm{ww} ; \mathrm{P}=0.52$ ), nor was there any difference in mercury concentrations in albumen from micro-sampled eggs from nests that hatched all eggs $(\mathrm{N}=6 ; 0.08 \pm 0.02 \mu \mathrm{g} / \mathrm{g} \mathrm{ww})$, hatched only some eggs $(\mathrm{N}=8 ; 0.10 \pm 0.03 \mu \mathrm{g} / \mathrm{g} \mathrm{ww})$, were fully depredated or destroyed $(\mathrm{N}=8 ; 0.07 \pm 0.03 \mu \mathrm{g} / \mathrm{g} \mathrm{ww})$, or abandoned $(\mathrm{N}=2 ; 0.09 \pm 0.04 \mu \mathrm{g} / \mathrm{g} \mathrm{ww}$; table 10). After accounting for possible effects of wetland site and nest initiation date, mercury concentrations in albumen of micro-sampled eggs did not differ among the possible combinations of fates of both control and micro-sampled eggs $\left(\mathrm{F}_{2,19}=0.30, \mathrm{P}=0.74\right.$; table 11)

Black-Necked Stilts. - There was no effect of the micro-sampled egg's mercury concentration on nest survival of the full clutch in black-necked stilts after statistically accounting for site, nest initiation date, and nest age (Generalized Linear Model: albumen THg concentration: $z$-value $=-0.74$, $\mathrm{P}=0.46$; site: $z$-value $=1.70, \mathrm{P}=0.09$; nest age: $z$-value $=-0.81, \mathrm{P}=0.42$; nest age $^{2}: z$-value $=0.94, \mathrm{P}=0.35$; nest initiation date: $z$-value $=0.65, \mathrm{P}=0.52$ ). A total of 25 black-necked stilt nests and 364 exposure days were used in this analyses. Out of the 25 black-necked stilt eggs that were micro-sampled, 17 failed, whereas 18 of the eggs designated as the sham egg and 18 of the eggs designated as the control egg from the same nest failed (table 9). After accounting for possible effects of site and nest initiation date, mercury concentrations in albumen from micro-sampled eggs that hatched were not different than 
concentrations in albumen from micro-sampled eggs that failed (hatched eggs: $0.24 \pm 0.12 \mu \mathrm{g} / \mathrm{g} \mathrm{ww}$; failed eggs: $0.31 \pm 0.05 \mu \mathrm{g} / \mathrm{g} \mathrm{ww} ; \mathrm{P}=0.19)$, nor was there any difference in mercury concentrations in albumen from micro-sampled eggs from nests that hatched all eggs $(\mathrm{N}=5 ; 0.33 \pm 0.12 \mu \mathrm{g} / \mathrm{g} \mathrm{ww})$, hatched only some eggs $(\mathrm{N}=6 ; 0.23 \pm 0.14 \mu \mathrm{g} / \mathrm{g} w \mathrm{w})$, were fully depredated or destroyed $(\mathrm{N}=13 ; 0.32 \pm 0.05 \mu \mathrm{g} / \mathrm{g}$ $\mathrm{ww})$, or abandoned $(\mathrm{N}=1 ; 0.17 \mu \mathrm{g} / \mathrm{g}$ ww; table 10$)$. After accounting for possible effects of wetland site and nest initiation date, mercury concentrations in albumen of micro-sampled eggs did not differ among the possible combinations of fates of both control and micro-sampled eggs $\left(\mathrm{F}_{3,18}=1.23, \mathrm{P}=0.33\right.$; table 11).

\section{Conclusions and Management Implications}

\section{Contaminant Exposure Risk to Breeding Birds}

We evaluated the risk of mercury and selenium contamination to 33 species of birds breeding within Great Salt Lake, primarily at Bear River Migratory Bird Refuge, and identified the waterbird species and areas that were at greatest risk to contamination. Mercury and selenium concentrations in eggs differed substantially among birds. Caspian terns, Forster's terns, snowy plovers, black-necked stilts, great egrets, and snowy egrets had the highest egg mercury concentrations. Eared grebes, Forster's terns, black-crowned night herons, snowy plovers, Franklin's gulls, and redhead ducks had the highest egg selenium concentrations. Overall, a substantial percentage of eggs sampled from wetlands of Great Salt Lake had mercury or selenium concentrations greater than common toxicity or regulatory thresholds (table 3). Some eggs exceeded contaminant concentrations that correspond to a level that might trigger a regulatory response by the Utah Department of Natural Resources, Division of Water Quality in the Gilbert Bay area of Great Salt Lake (detailed above). These risk levels, together with the potential effects of declining egg volume with increasing egg mercury concentrations in four species (snowy plover, gadwall, black-necked stilt, and Forster's tern) and higher mercury concentrations in abandoned eggs relative to random eggs for two species (white-faced ibis and marsh wrens), suggest that mercury could be impairing reproduction of some bird species breeding in Great Salt Lake. However, we detected no effect of egg mercury concentration on nest survival of the remaining clutch in Forster's terns, American, avocets, or black-necked stilts using either the surrogate egg or microsampling methods. We conducted these more detailed reproductive impairment studies in 2012 which, we later learned, had substantially lower mercury concentrations in eggs than in either 2010 or 2011 (2012 egg mercury concentrations were $14 \%$ to $60 \%$ lower than 2010 or 2011 , depending on the species and year). Therefore, these reproductive impairment studies could be repeated in years with higher mercury exposure levels like we observed in 2010 and 2011. This study suggests mercury and selenium concentrations in breeding birds continue to be an area of conservation concern for the Great Salt Lake ecosystem and warrants close monitoring.

\section{Wetland-Specific Exposure and Management}

Mercury concentrations in eggs tended to be lower at the BRMB Refuge than at other areas throughout Great Salt Lake (which received only limited sampling). In particular, mercury concentrations in eggs collected near Antelope Island and at Farmington Bay were consistently higher in egg mercury concentrations than all other regions, especially BRMB Refuge. Yet, among several species, particular wetlands within BRMB Refuge exhibited higher or nearly as high egg mercury concentrations as Antelope Island and Farmington Bay. Within the BRMB Refuge, Wetland Complex 3, Wetland Complex 5, and Wetland Complex 8GSL tended to exhibit elevated egg mercury 
concentrations relative to other areas of the BRMB Refuge. For example, mercury concentrations in eggs were highest for American coots in 3B and 3E, for Franklin's gulls in 3K, for redheads in 3D, and for yellow-headed blackbirds in 3E. Wetland $5 \mathrm{C}$ had the highest mercury concentrations in eggs of American avocets and Forster's terns, followed by several wetlands in Wetland Complex 3. For songbirds, mercury concentrations in eggs collected in 8GSL were typically the highest of any other wetland sampled at BRMB Refuge. Wetland-specific differences in egg mercury concentrations may not indicate local mercury exposure for some species that travel long-distances from their nests to forage, so it is important to interpret these wetland-specific mercury concentrations with attention to the specific species' use of foraging habitats. A useful follow-up study would be to use telemetry to track bird movements and areas of contaminant exposure in relation to mercury concentrations in adult birds and their eggs (such as was done by Ackerman and others, 2007, 2008b, 2014).

There are many biogeochemical mechanisms that can result in different methylmercury exposure levels among wetlands. One of the potential mechanisms that wetland managers could manipulate is the frequency, duration, and depth of wetland flooding. Wetting and drying patterns in wetlands result in varying redox conditions, which can promote methylmercury production within sediments (Ullrich and others, 2001). For example, Ackerman and Eagles-Smith (2010a) found that mercury concentrations in fish were highest in seasonally flooded rice wetlands and lowest in permanently flooded wetlands in California's Central Valley. Similarly, Snodgrass and others (2000) found that mercury concentrations in fish were highest in South Carolina wetlands that were shallower and had larger water-level fluctuations. Experimental flooding of wetlands in the Experimental Lakes Area of Canada also caused increases in mercury concentrations and body burdens in small fishes held in mesh pens (Bodaly and Fudge, 1999). Also of particular relevance to Great Salt Lake and BRMB Refuge, salinity can influence methylmercury production and bioaccumulation (Ullrich and others, 2001). For example, Eagles-Smith and Ackerman (2014) found that mercury concentrations in fish were highest in estuarine wetlands that were more saline. We found that mercury concentrations in bird eggs were higher in areas of Great Salt Lake and generally lower in the more freshwater wetlands adjacent to Great Salt Lake at BRMB Refuge. A better understanding of the role of salinity on mercury cycling and bioaccumulation within wetlands at Great Salt Lake could provide a potential tool for wetland managers by manipulating wetland salinity levels through hydrologic controls where feasible, and future studies could investigate the potential for lowering methylmercury bioaccumulation by altering salinity levels in wetlands. Wetland vegetation abundance can also promote methylmercury production in wetland sediments (Windham-Myers and others, 2009). These results indicate that intermittently flooded, shallow wetlands with ample vegetation and at higher salinities may result in higher mercury concentrations in birds. Therefore, there may be opportunity to modify existing wetland management practices, particularly water management, in order to reduce bird egg mercury concentrations within wetland complexes identified as hot spots, as well as throughout the BRMB Refuge.

\section{References Cited}

Ackerman, J.T., and Eagles-Smith, C.A., 2009, Integrating toxicity risk in bird eggs and chicks-Using chick down feathers to estimate mercury concentrations in eggs: Environmental Science and Technology, v. 43, no. 6, p. 2,166-2,172.

Ackerman, J.T., and Eagles-Smith, C.A., 2010a, Agricultural wetlands as potential hotspots for mercury bioaccumulation-Experimental evidence using caged fish: Environmental Science and Technology, v. 44, no. 4, p. 1,451-1,457.

Ackerman, J.T., and Eagles-Smith, C.A., 2010b, Accuracy of egg flotation throughout incubation to determine embryo age and incubation day in waterbird nests: Condor, v. 112, no. 3, p. 438-446. 
Ackerman, J.T., Eagles-Smith, C.A., Heinz, G.H., De La Cruz, S.E., Takekawa, J.Y., Miles, A.K., Adelsbach, T.L., Herzog, M.P., Bluso-Demers, J.D., Demers, S.A., Herring, G., Hoffman, D.J., Harman, C.A., Willacker, J.J., Suchanek, T.H., Schwarzbach, S.E., and Maurer, T.C., 2014, Mercury in birds of San Francisco Bay-Delta, California-Trophic pathways, bioaccumulation, and ecotoxicological risk to avian reproduction: U.S. Geological Survey Open-File Report 2014-1251, $202 \mathrm{p}$.

Ackerman, J.T., Eagles-Smith, C.A., Takekawa, J.Y., Bluso, J.D., and Adelsbach, T.L., 2008a, Mercury concentrations in blood and feathers of prebreeding Forster's terns in relation to space use of San Francisco Bay, California, USA, habitats: Environmental Toxicology and Chemistry, v. 27, no. 4, p. 897-908.

Ackerman, J.T., Eagles-Smith, C.A., Takekawa, J.Y., Bluso, J.D., and Adelsbach, T.L., 2008b, Mercury concentrations in blood and feathers of prebreeding Forster's terns in relation to space use of San Francisco Bay, California, USA, habitats: Environmental Toxicology and Chemistry, no. 4, p. 897908.

Ackerman, J.T., Eagles-Smith, C.A., Takekawa, J.Y., Demers, S.A., Adelsbach, T.L., Bluso, J.D., Miles, A.K., Warnock, N., Suchanek, T.H., and Schwarzbach, S.E., 2007, Mercury concentrations and space use of pre-breeding American avocets and black-necked stilts in San Francisco Bay: Science of the Total Environment, v. 384, no. 1-3, p. 452-466.

Ackerman, J.T., Herzog, M.P., and Schwarzbach, S.E., 2013, Methylmercury is the predominant form of mercury in bird eggs-A synthesis: Environmental Science and Technology, v. 47, p. 2,052-2,060.

Ackerman, J.T., Overton, C.T., Casazza, M.L., Takekawa, J.Y., Eagles-Smith, C.A., Keister, R.A., and Herzog, M.P., 2012, Does mercury contamination reduce body condition of endangered California clapper rails?: Environmental Pollution, v. 162, p. 439-448.

Albers, P.H., Koterba, M.T., Rossmann, R., Link, W.A., French, J.B., Bennett, R.S., and Bauer, W.C., 2007, Effects of methylmercury on reproduction in American kestrels: Environmental Toxicology and Chemistry, v. 26, no. 9, p. 1,856-1,866.

Aldrich, T., and Paul, D., 2002, Avian ecology of Great Salt Lake, in Gwynn, J., ed., Great Salt LakeAn overview of change: Salt Lake City, Utah Department of Natural Resources and Utah Geological Survey Special Publication, p. 343-374.

Bodaly, R., and Fudge, R., 1999, Uptake of mercury by fish in an experimental boreal reservoir: Archives of Environmental Contamination and Toxicology: v. 109, no. 43, p. 103-109.

Cavitt, J.F., Jones, S., Wilson, N., Dieni, J., Zimmerman, T., Doster, R., and Howe, W., 2014, Atlas of breeding colonial waterbirds in the interior western United States. Research Report: Denver, Colo., U.S. Fish and Wildlife Service, p. 26.

Conover, M.R., and Vest, J.L., 2009, Concentrations of selenium and mercury in eared grebes (Podiceps nigricollis) from Utah's Great Salt Lake, USA.: Environmental Toxicology and Chemistry, v. 28 , no. 6, p. 1,319-23.

Diaz, X., Johnson, W.P., and Naftz, D.L., 2009, Selenium mass balance in the Great Salt Lake, Utah: The Science of the Total Environment, v. 407, no. 7, p. 2,333-2,341.

Driscoll, C., Mason, R., Chan, H., Jacob, D., and Pirrone, N., 2013, Mercury as a global pollutantSources, pathways, and effects: Environmenal Science and Technology, v. 47, p. 4,967-4,983.

Eagles-Smith, C.A., and Ackerman, J.T., 2014, Mercury bioaccumulation in estuarine wetland fishesEvaluating habitats and risk to coastal wildlife: Environmental Pollution, v. 193, p. 147-155.

Eagles-Smith, C.A., Ackerman, J.T., Cruz, S.E.W.D. La, De La Cruz, S.E.W., and Takekawa, J.Y., 2009a, Mercury bioaccumulation and risk to three waterbird foraging guilds is influenced by foraging ecology and breeding stage: Environmental Pollution, v. 157, no. 7, p. 1,993-2,002. 
Eagles-Smith, C.A., Ackerman, J.T., Yee, J., and Adelsbach, T.L., 2009b, Mercury demethylation in waterbird livers - Dose-response thresholds and differences among species: Environmental Toxicology and Chemistry, v. 28, no. 3, p. 568-577.

Evers, D.C., Taylor, K.M., Major, A., Taylor, R.J., Poppenga, R.H., and Scheuhammer, A.M., 2003, Common loon eggs as indicators of methylmercury availability in North America: Ecotoxicology, $\mathrm{v}$. 12, no. $1-4$, p. 69-81.

Getis, A., and Ord, J.K., 1992, The analysis of spatial association by use of distance statistics: Geographical Analysis, v. 24, no. 3, p. 189-206.

Hall, B.D., Aiken, G.R., Krabbenhoft, D.P., Marvin-DiPasquale, M., and Swarzenski, C.M., 2008, Wetlands as principal zones of methylmercury production in southern Louisiana and the Gulf of Mexico region: Environmental Pollution, v. 154, no. 1, p. 124-134.

Hargreaves, A.L., Whiteside, D.P., and Gilchrist, G., 2011, Concentrations of 17 elements, including mercury, in the tissues, food and abiotic environment of Arctic shorebirds: The Science of the Total Environment, v. 409, no. 19, p. 3,757-3,770.

Hartman, C.A., Ackerman, J.T., Herring, G., Isanhart, J., and Herzog, M., 2013, Marsh wrens as bioindicators of mercury in wetlands of Great Salt Lake-Do blood and feathers reflect site-specific exposure risk to bird reproduction?: Environmental Science and Technology, v. 47, no. 12, p. 6,5976,605 .

Heinz, G.H., Hoffman, D.J., Klimstra, J.D., Stebbins, K.R., Kondrad, S.L., and Erwin, C.A., 2009, Species differences in the sensitivity of avian embryos to methylmercury: Archives of Environmental Contamination and Toxicology, v. 56, no. 1, p. 129-138.

Herring, G., Ackerman, J.T., and Eagles-Smith, C.A., 2010, Embryo malposition as a potential mechanism for mercury-induced hatching failure in bird eggs: Environmental Toxicology and Chemistry, v. 29, no. 8, p. 1,788-1,794.

Hoyt, D.F., 1979, Practical methods of estimating volume and fresh weight of bird eggs: The Auk, v. 96, no. 1, p. 73-77.

Jackson, A.K., Evers, D.C., Etterson, M.A., Condon, A.M., Folsom, S.B., Detweiler, J., Schmerfeld, J., and Cristol, D.A., 2011, Mercury exposure affects the reproductive success of a Free-Living Terrestrial Songbird, the Carolina Wren (Thryothorus ludovicianus): Auk, v. 128, no. 4, p. 759-769.

Naftz, D., Angeroth, C., Kenney, T., Waddell, B., Darnall, N., Silva, S., Perschon, C., and Whitehead, J., 2008a, Anthropogenic influences on the input and biogeochemical cycling of nutrients and mercury in Great Salt Lake, Utah, USA: Applied Geochemistry, v. 23, no. 6, p. 1,731-1,744.

Naftz, D.L., Johnson, W.P., Freeman, M.L., Beisner, K., Diaz, X., and Cross, V.A., 2008b, Estimation of selenium loads entering the south arm of Great Salt Lake, Utah, from May 2006 through March 2008: U.S. Geological Survey Scientific Investigations Report 2008-5069, 40 p.

Ohlendorf, H.M., and Heinz, G.H., 2011, Selenium in birds, in Beyer, W.N., and Meador, J.P. eds., Environmental contaminants in biota-Interpreting tissue concentrations ( $2 \mathrm{~d}$ ed): Boca Raton, Flor., CRC Press, p. 669-701..

Scheuhammer, A.M., Meyer, M.W., Sandheinrich, M.B., and Murray, M.W., 2007, Effects of environmental methylmercury on the health of wild birds, mammals, and fish: Ambio, v. 36, no. 1, p. $12-18$.

Seber, G.A.F., 1982, The estimation of animal abundance and related parameters (2d ed): New York, Macmillan, 672 p. 
Seiler, R.L., Skorupa, J.P., Naftz, D.L., and Nolan, B.T., 2003, Irrigation-induced contamination of water, sediment, and biota in the Western United States - Synthesis of data from the National Irrigation Water Quality Program: U.S. Geological Survey Professional Paper 1655, 123 p.

Shaffer, T.L., 2004, A unified approach to analyzing nest success: Auk, v. 121, no. 2, p. 526-540.

Snodgrass, J.W., Jagoe, C.H., Bryan, Jr., A.L., Brant, H.A., and Burger, J., 2000, Effects of trophic status and wetland morphology, hydroperiod, and water chemistry on mercury concentrations in fish: Canadian Journal of Fisheries and Aquatic Sciences, v. 57, no. 1, p. 171-180.

Stebbins, K.R., Klimstra, J.D., Eagles-Smith, C.A., Ackerman, J.T., and Heinz, G.H., 2009, A nonlethal microsampling technique to monitor the effects of mercury on wild bird eggs: Environmental Toxicology and Chemistry, v. 28, no. 3, p. 465-470.

Stutz, J., Ackermann, R., Fast, J.D., and Barrie, L., 2002, Atmospheric reactive chlorine and bromine at the Great Salt Lake, Utah: Geophysical Research Letters, v. 29, no. 10, p. 1-4.

Thomas, S.M., Lyons, J.E., Andres, B.A., Elliot, E., Palacios, E., Cavitt, J.F., Royle, J.A., Suzanne, D., Maty, K., Howe, W.H., and others, 2012, Population size of snowy plovers breeding in North America: Waterbirds, v. 35, no. 1, p. 1-14.

Thompson, D.R., 1996, Mercury in birds and terrestrial mammals, in Beyer, W.N., Heinz, G.H., and Redmon-Norwood, A.W., eds., Environmental contaminants in wildlife, interpreting tissue concentrations: Boca Raton, Flor., CRC Press LCC, p. 341-356.

Tsipoura, N., Burger, J., and Feltes, R., 2008, Metal concentrations in three species of passerine birds breeding in the Hackensack Meadowlands of New Jersey: Environmental Research, v. 107, p. 218228.

U.S. Environmental Protection Agency, 2000, Method 7473, Mercury in solids and solutions by thermal decomposition, amalgamation, and atomic absorption spectrophotometry. In Test Methods for Evaluating Solid Waste, Physical/Chemical Methods; SW 846, Update IVA; U.S. Government Printing Office: Washington, D.C..

Ullrich, S.M., Tanton, T.W., and Abdrashitova, S.A., 2001, Mercury in the aquatic environment-A review of factors affecting methylation: Critical Reviews in Environmental Science and Technology, v. 31, no. 3, p. 241-293.

Vest, J.L., Conover, M.R., Perschon, C., Luft, J., and Hall, J.O., 2009, Trace element concentrations in wintering waterfowl from the Great Salt Lake, Utah: Archives of Environmental Contamination and Toxicology, v. 56, no. 2, p. 302-316.

Wiener, J.G., Krabbenhoft, D.P., Heinz, G.H., and Scheuhammer, A.M., 2003, Ecotoxicology ofmercury, in Hoffman, D.J., Rattner, B.A., Burton, G.A.J., Cairns, J.J., eds., Handbook of Ecotoxicology (2d ed.):Boca Raton, Flor., CRC Press LCC, 1,312 p..

Windham-Myers, L., Marvin-Dipasquale, M., Krabbenhoft, D.P., Agee, J.L., Cox, M.H., HerediaMiddleton, P., Coates, C., and Kakouros, E., 2009, Experimental removal of wetland emergent vegetation leads to decreased methylmercury production in surface sediment: Journal of Geophysical Research, v. 114, p. 1-14.

Zar, J., 1999, Biostatistical Analysis (4th ed): Upper Saddle River, New Jersey, Prentice-Hall, 662 p. 


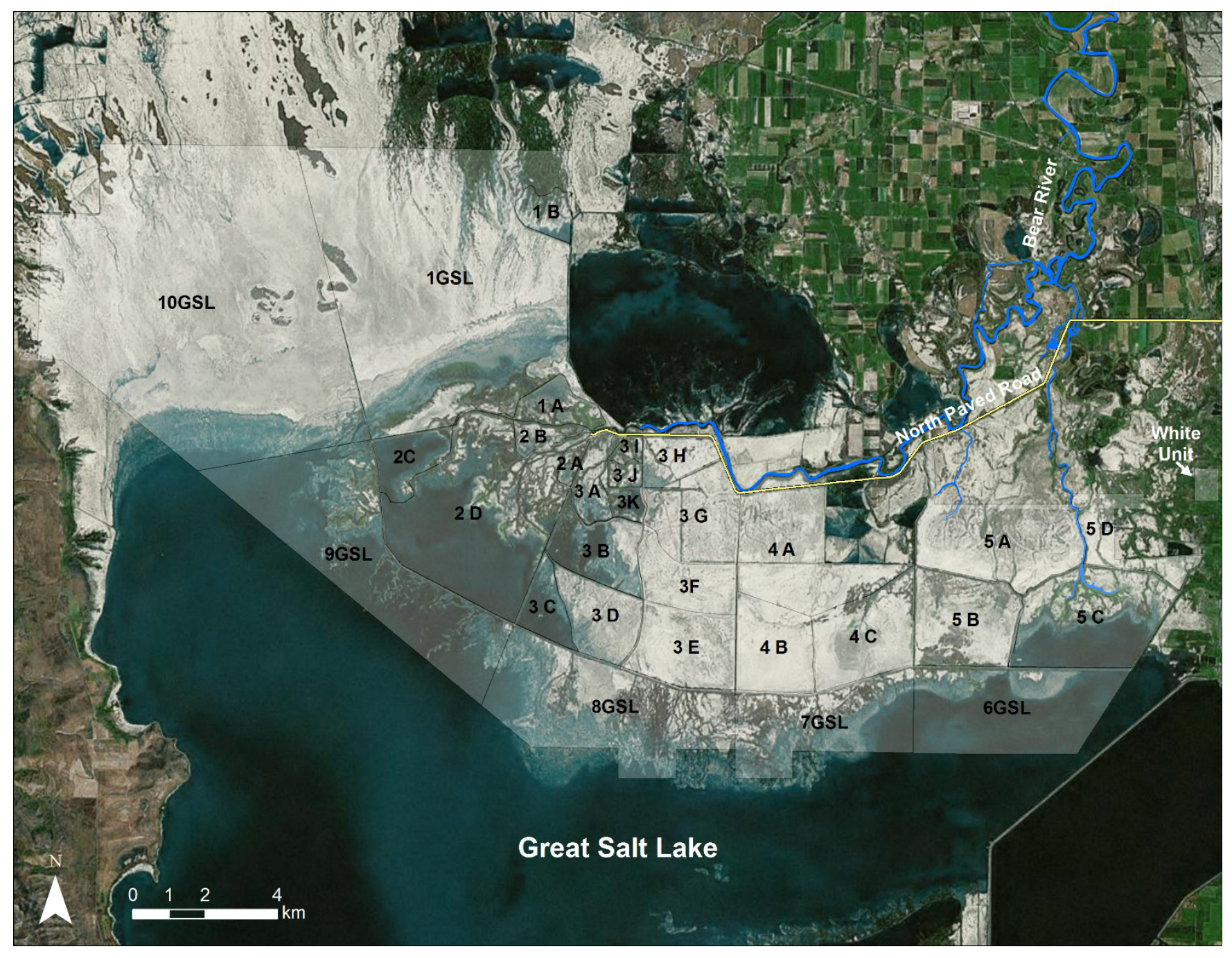

Figure 1. Map showing wetland sites at Bear River Migratory Bird Refuge in Great Salt Lake, Utah, 2010-2012. 


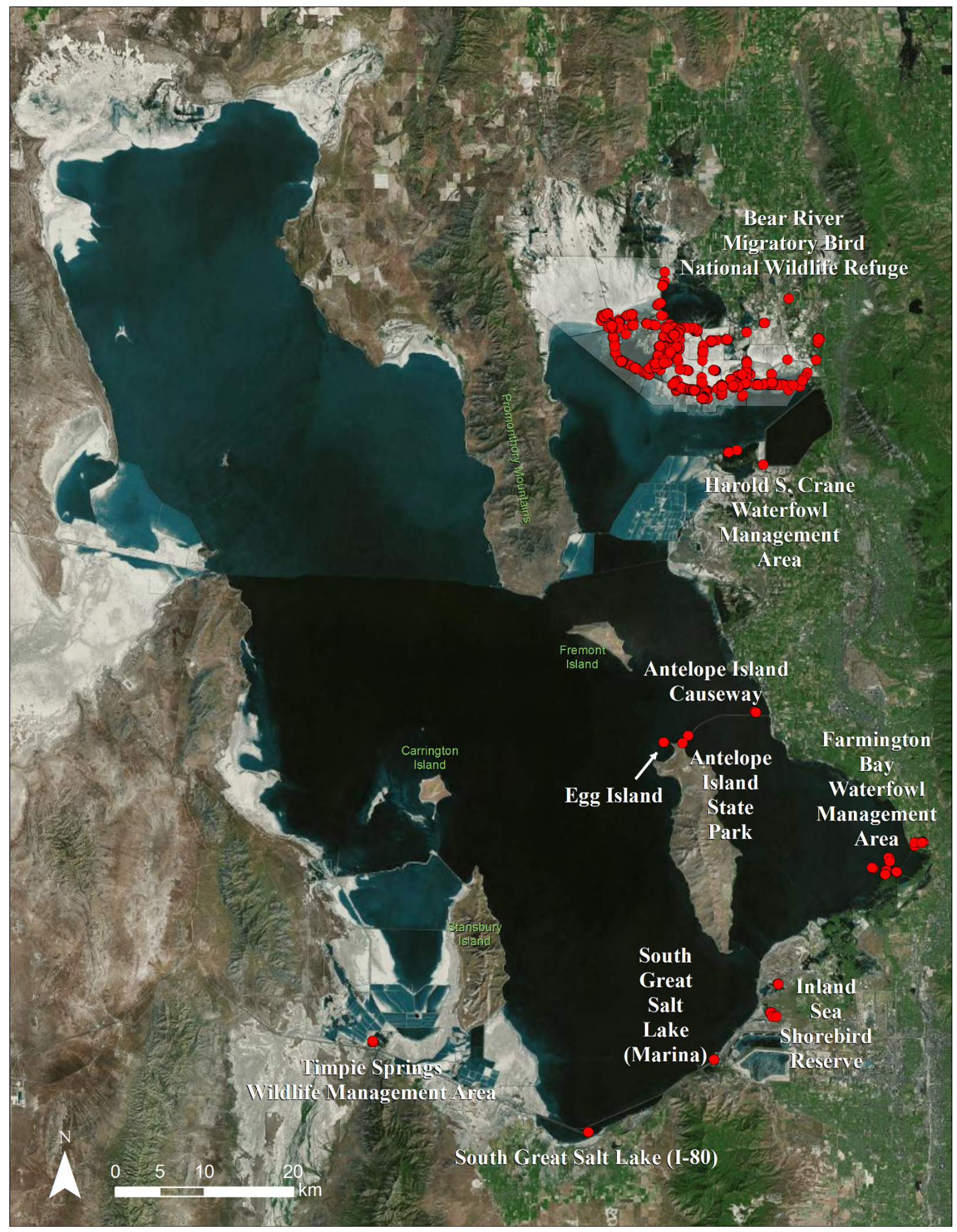

Figure 2. Map showing study sites and locations where eggs from 33 bird species were sampled (solid circles) in Great Salt Lake, Utah, 2010-2012. 


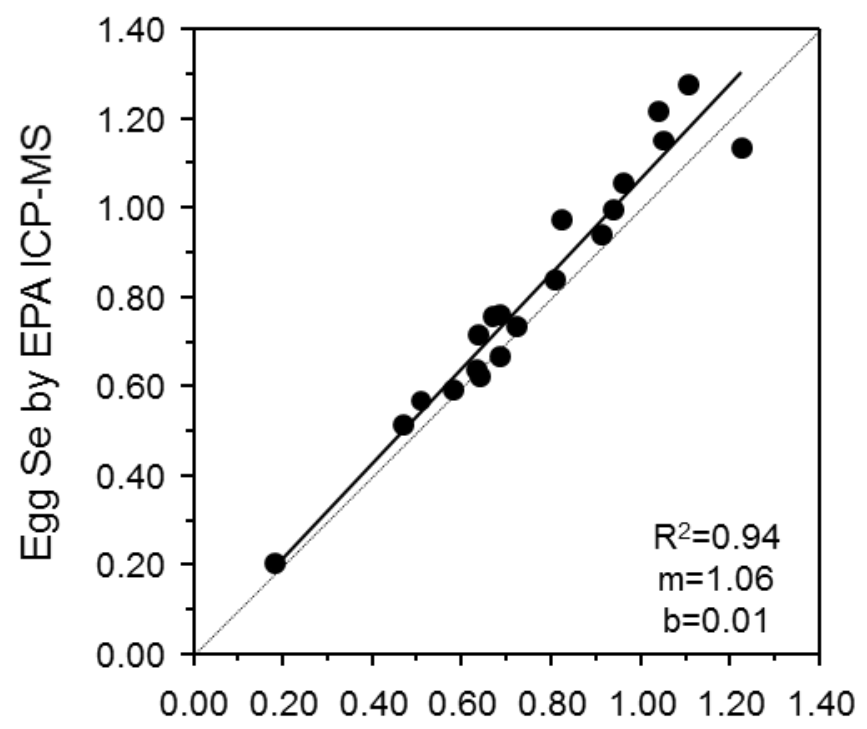

Egg Se by Battelle FIAS

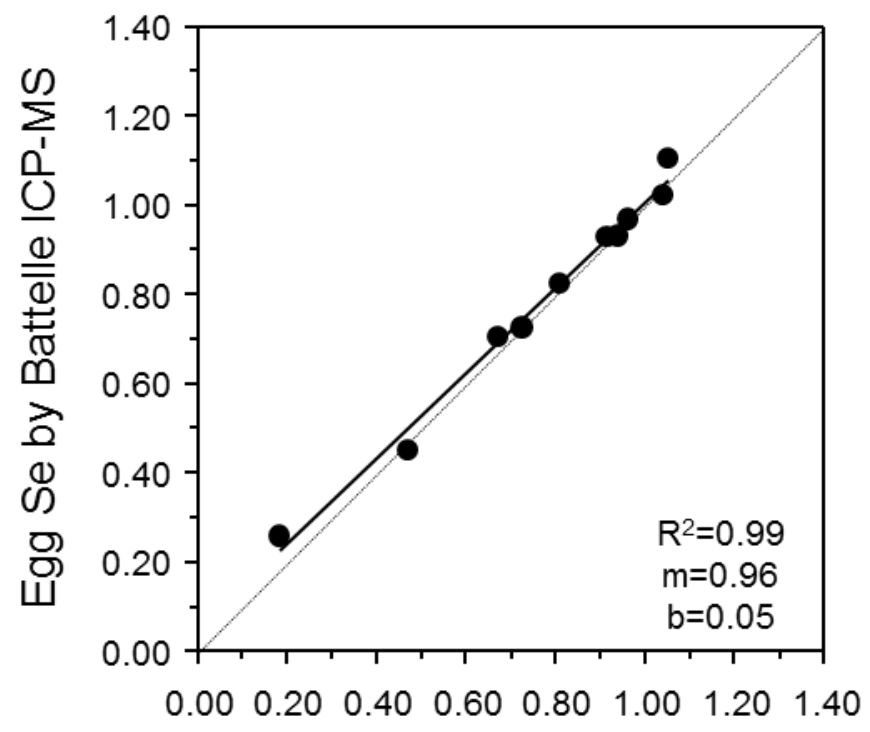

Egg Se by Battelle FIAS

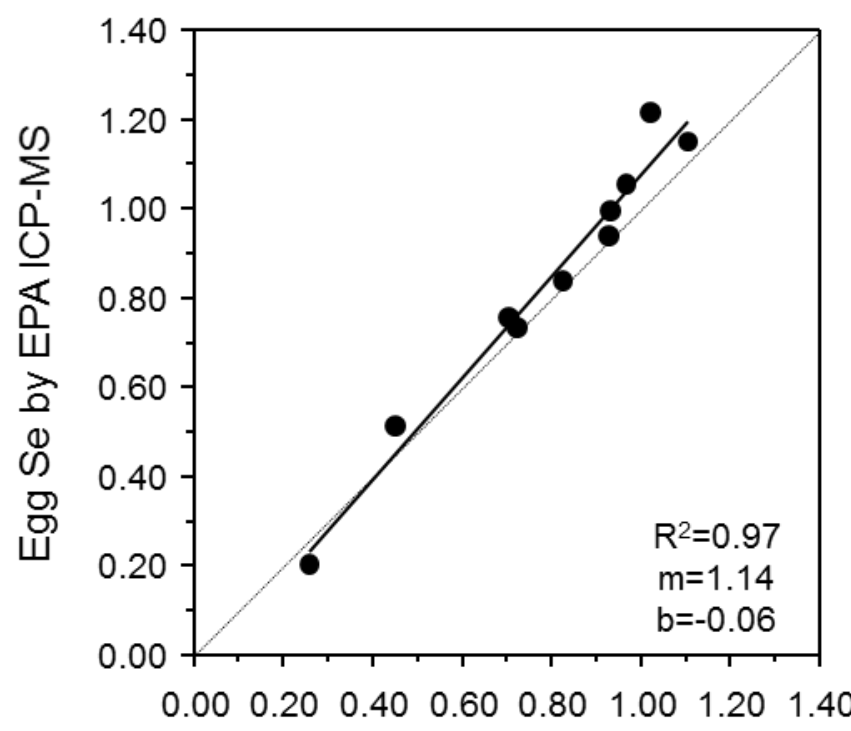

Egg Se by Battelle ICP-MS

Figure 3. Selenium concentration in bird eggs ( $\mu \mathrm{g} / \mathrm{g} \mathrm{fww}$ ) as determined by (1) hydride generation flow injection atomic spectroscopy (FIAS) and (2) inductively coupled mass spectrometry (ICP-MS) for birds breeding in Great Salt Lake, Utah, 2010-2011. The three different panels show these two methods used for the same eggs at Battelle Marine Sciences (Battelle) and Environmental Protection Agency (EPA) Laboratories. 


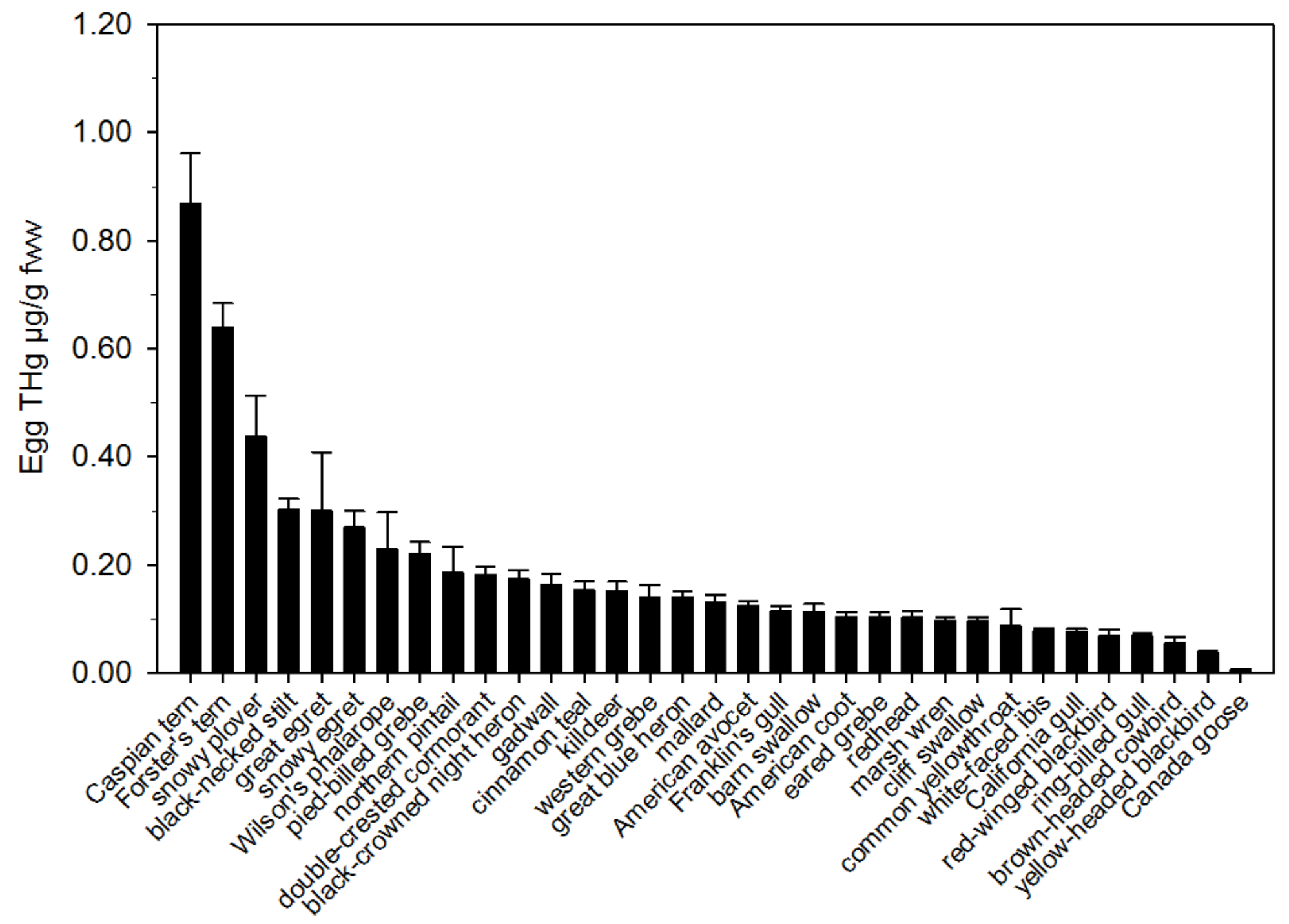

\section{Species}

Figure 4. Total mercury concentrations ( $\mu \mathrm{g} / \mathrm{g} \mathrm{fww})$ in eggs from 33 bird species breeding in Great Salt Lake, Utah, 2010-2012. Values are least squares means \pm standard errors, which account for the global model effects of species, region, and year. 


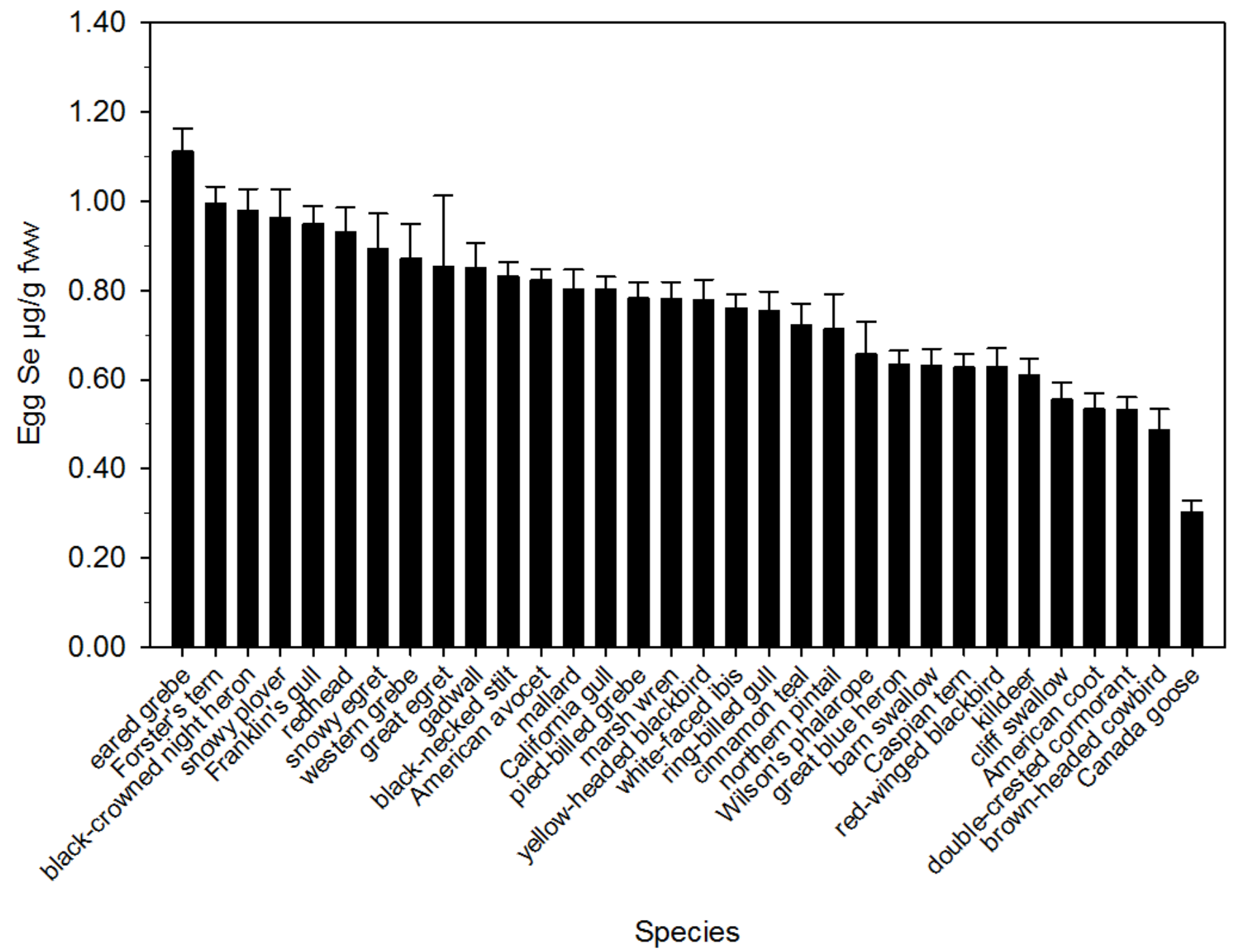

Figure 5. Selenium concentrations ( $\mu \mathrm{g} / \mathrm{g}$ fww) in eggs from 32 bird species breeding in Great Salt Lake, Utah, 2010-2011. Values are least squares means \pm standard errors, which account for the global model effects of species, region, and year. 


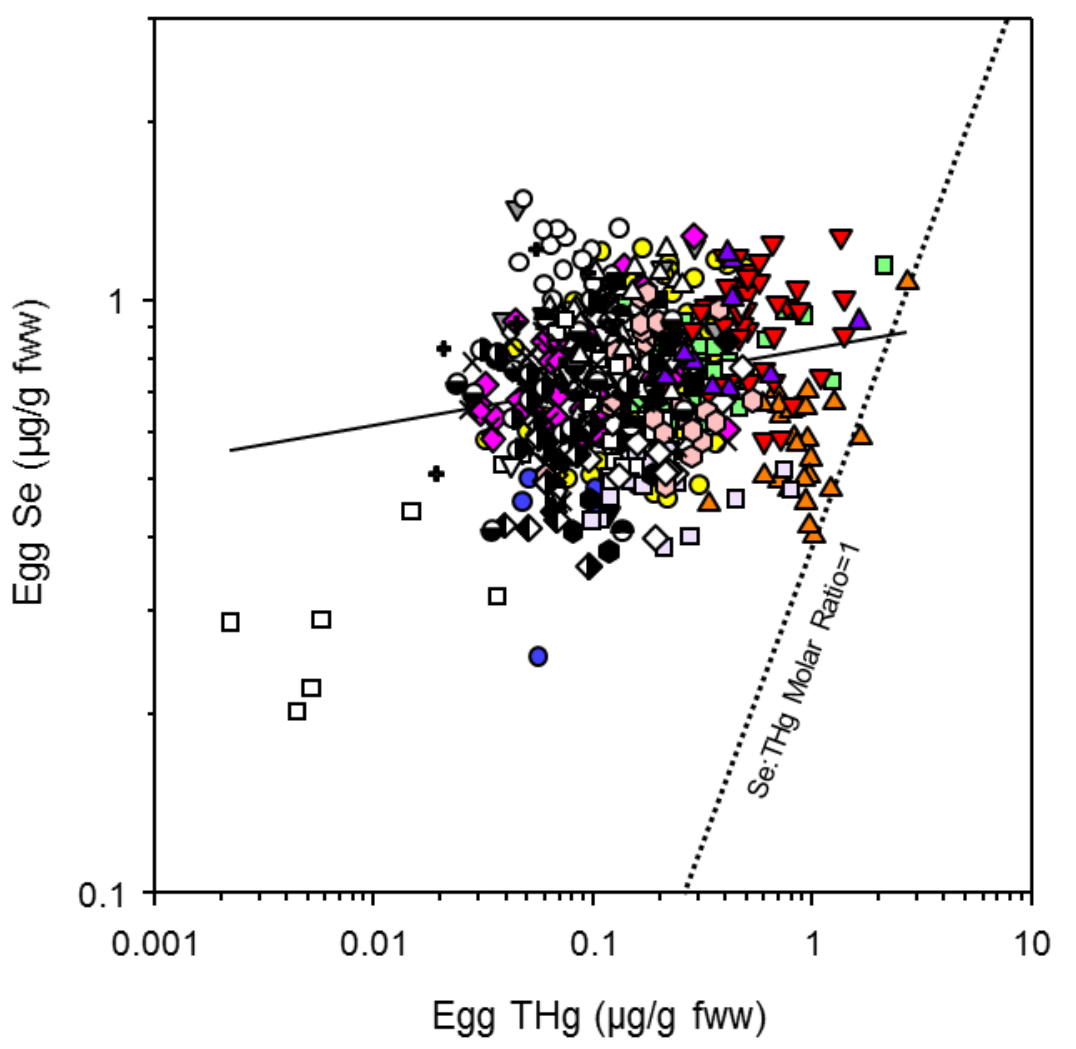

$\begin{array}{ll}\circ & \text { AMAV } \\ 0 & \text { AMCO } \\ \nabla & \text { BARS } \\ \nabla & \text { BCNH } \\ \bullet & \text { BHCO } \\ \square & \text { BNST } \\ \square & \text { CAGO } \\ \diamond & \text { CAGU } \\ \Delta & \text { CATE } \\ \nabla & \text { CITE } \\ \bullet & \text { CLSW } \\ 0 & \text { COYE } \\ \square & \text { DCCO } \\ 0 & \text { EAGR } \\ \nabla & \text { FOTE } \\ \Delta & \text { FRGU } \\ \square & \text { GADW } \\ \square & \text { GBHE } \\ \bullet & \text { GREG } \\ \diamond & \text { KILL } \\ \bullet & \text { MALL } \\ \nabla & \text { MAWR } \\ \bullet & \text { NOPI } \\ 0 & \text { PBGR } \\ \bullet & \text { RBGU } \\ \bullet & \text { REDH } \\ \bullet & \text { RWBL } \\ \Delta & \text { SNEG } \\ \Delta & \text { SNPL } \\ \square & \text { WEGR } \\ \times & \text { WFIB } \\ \diamond & \text { WIPH } \\ \bullet & \text { YHBL }\end{array}$

Figure 6. Correlation between egg selenium concentrations ( $\mu \mathrm{g} / \mathrm{g} \mathrm{fww})$ and egg total mercury concentrations $(\mu \mathrm{g} / \mathrm{g} \mathrm{fww})$ among 32 bird species breeding in Great Salt Lake, Utah, 2010-2011. The stippled line represents the 1:1 molar ratio between selenium and total mercury. 


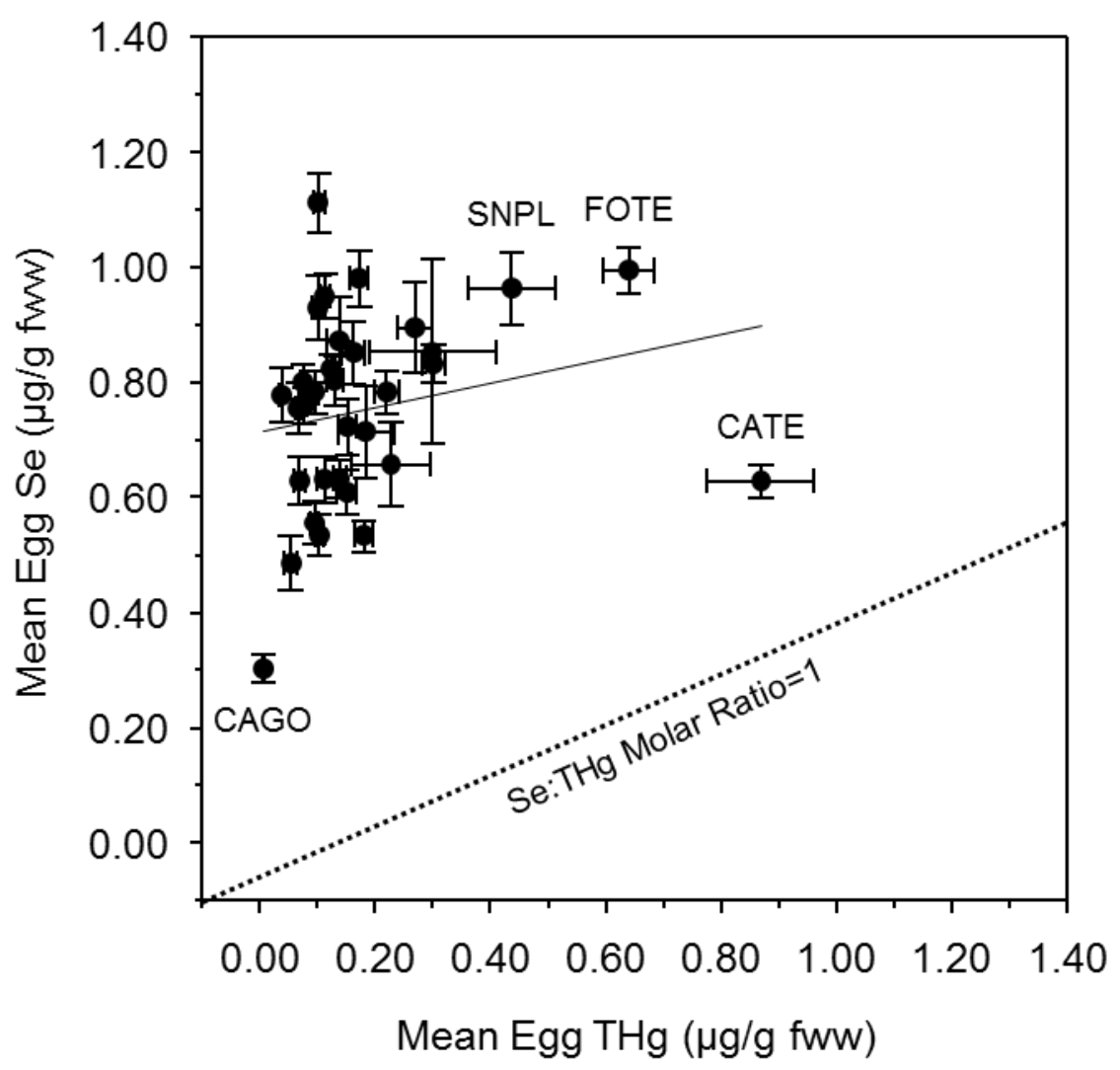

Figure 7. Correlation between species mean egg selenium concentrations ( $\mu \mathrm{g} / \mathrm{g} \mathrm{fww}$ ) and mean egg total mercury concentrations ( $\mu \mathrm{g} / \mathrm{g} \mathrm{fww}$ ) among 32 bird species breeding in Great Salt Lake, Utah, 2010-2011. The stippled line represents the 1:1 molar ratio between selenium and total mercury. Error bars represent standard errors. The four species outside of the primary cluster of species are labeled (SNPL: snowy plover; FOTE: Forster's tern; CATE: Caspian tern; CAGO: Canada goose). 

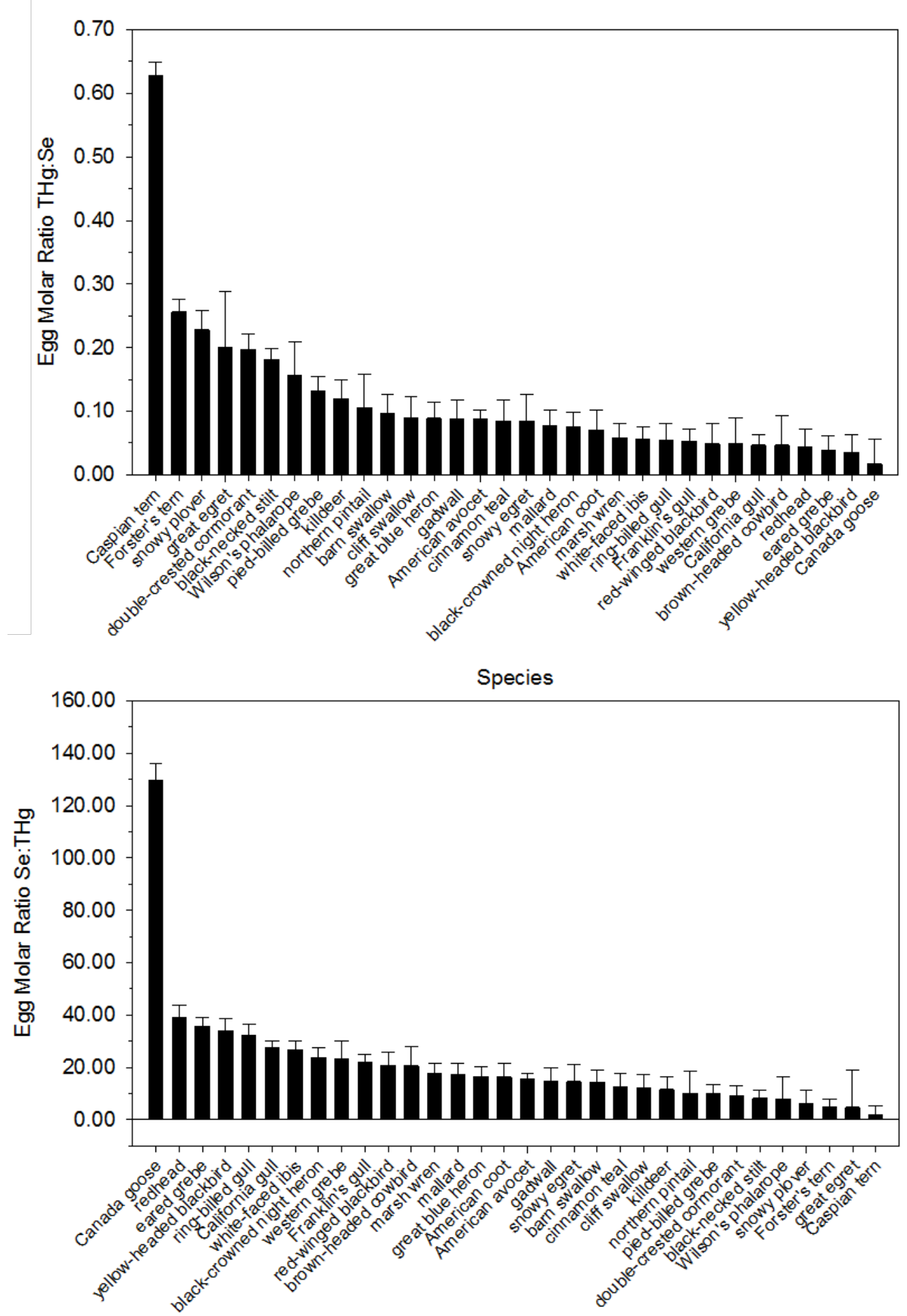

Species

Figure 8. Molar ratio of total mercury:selenium (top panel) and selenium:total mercury (bottom panel) in eggs from 32 bird species breeding in Great Salt Lake, Utah, 2010-2011. Values are least squares means \pm standard errors, which account for the global model effects of species, region, and year. 


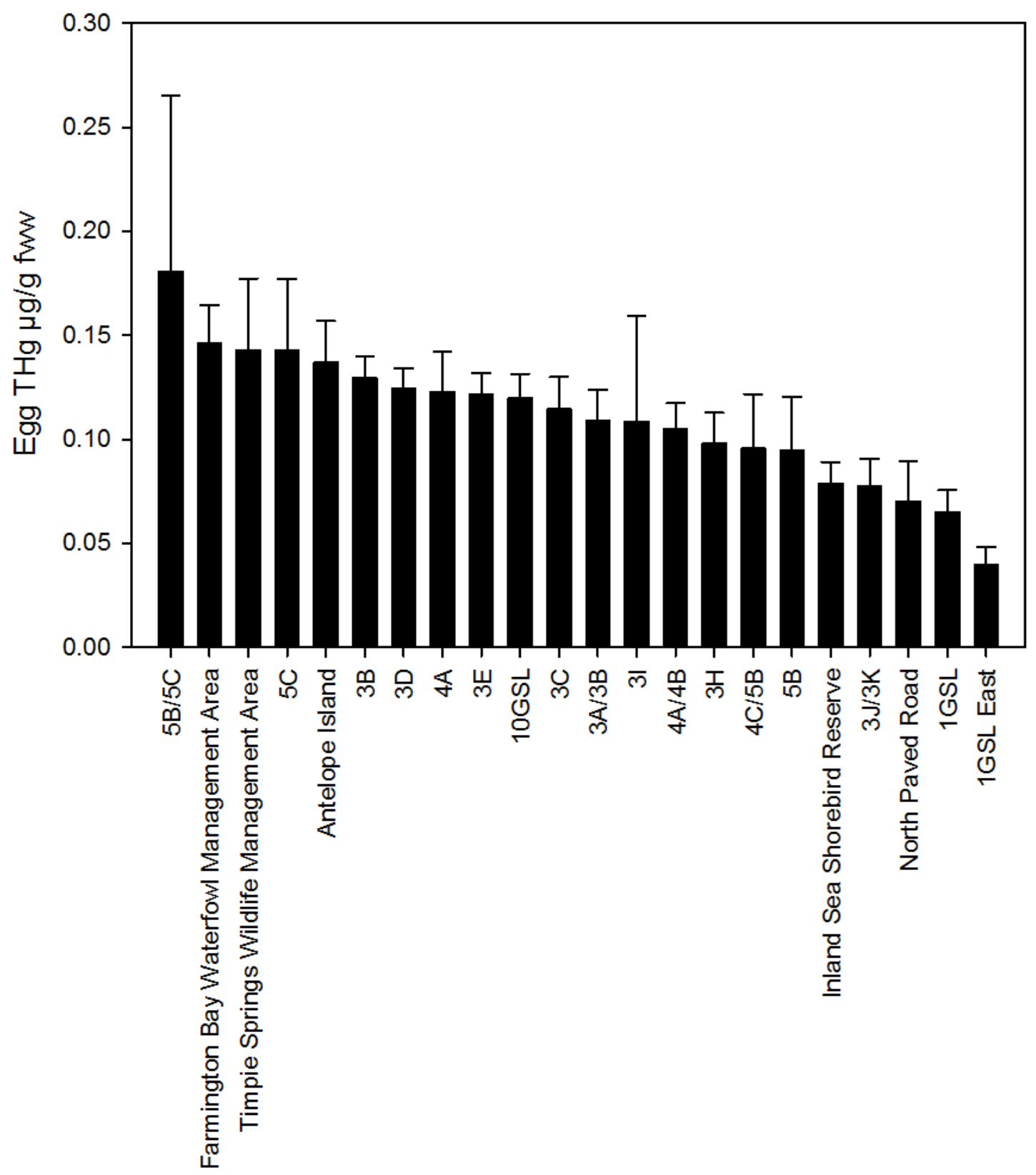

Wetland Site

Figure 9. Total mercury concentrations ( $\mu \mathrm{g} / \mathrm{g}$ fww) in eggs of American avocets breeding in various wetland sites within Great Salt Lake, Utah, 2010-2012. Values are least squares means \pm standard errors from a global model accounting for wetland site nested with region, region, year, and nest initiation date. Wetland sites with specific names occur within the Bear River Migratory Bird Refuge. 


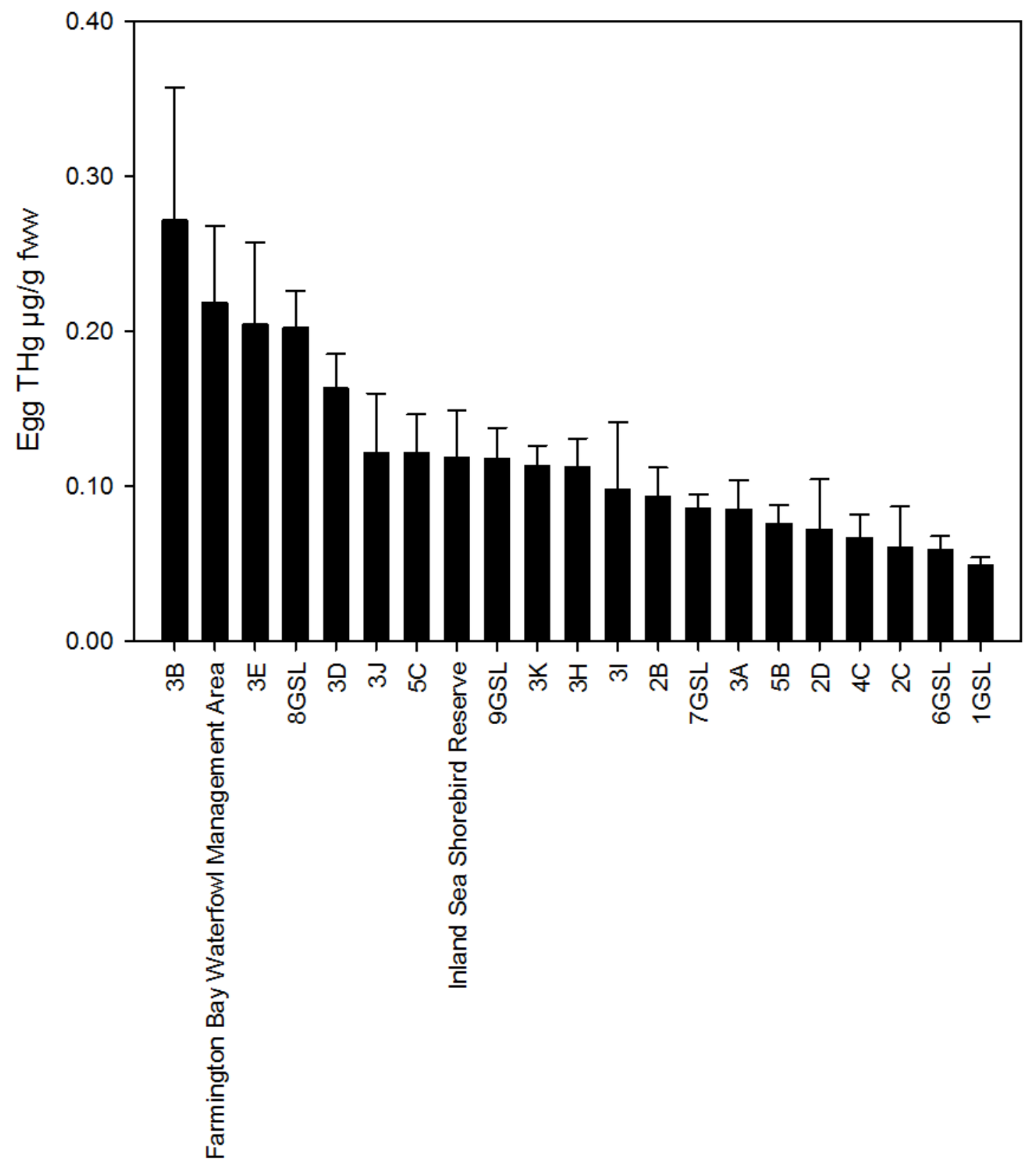

Wetland Site

Figure 10. Total mercury concentrations ( $\mu \mathrm{g} / \mathrm{g} \mathrm{fww}$ ) in eggs of American coots breeding in various wetland sites within Great Salt Lake, Utah, 2010-2012. Values are least squares means \pm standard errors from a global model accounting for wetland site nested with region, region, year, and nest initiation date. Wetland sites with specific names occur within the Bear River Migratory Bird Refuge. 


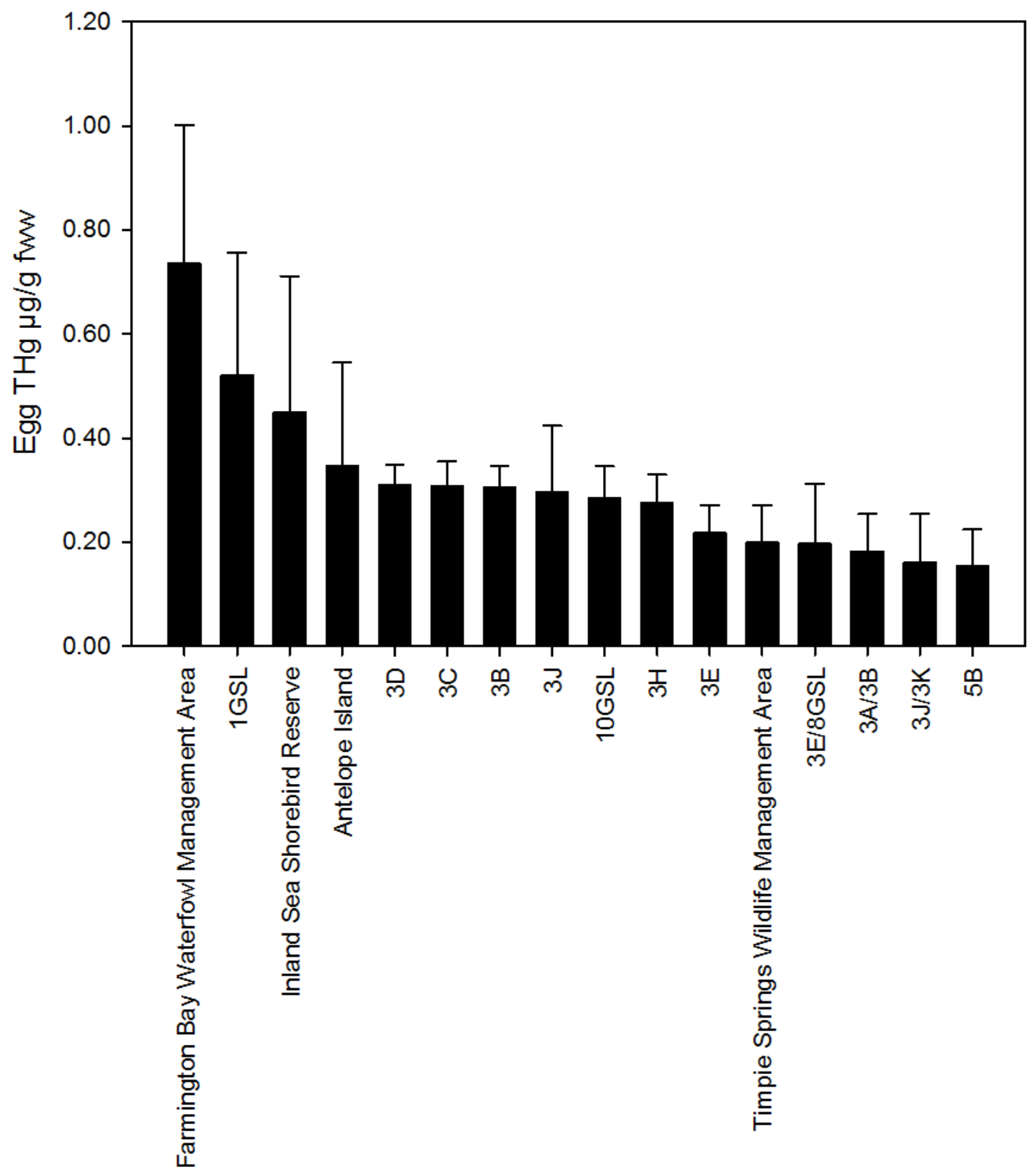

Wetland Site

Figure 11. Total mercury concentrations $(\mu \mathrm{g} / \mathrm{g} \mathrm{fww})$ in eggs of black-necked stilts breeding in various wetland sites within Great Salt Lake, Utah, 2010-2012. Values are least squares means \pm standard errors from a global model accounting for wetland site nested with region, region, year, and nest initiation date. Wetland sites with specific names occur within the Bear River Migratory Bird Refuge. 


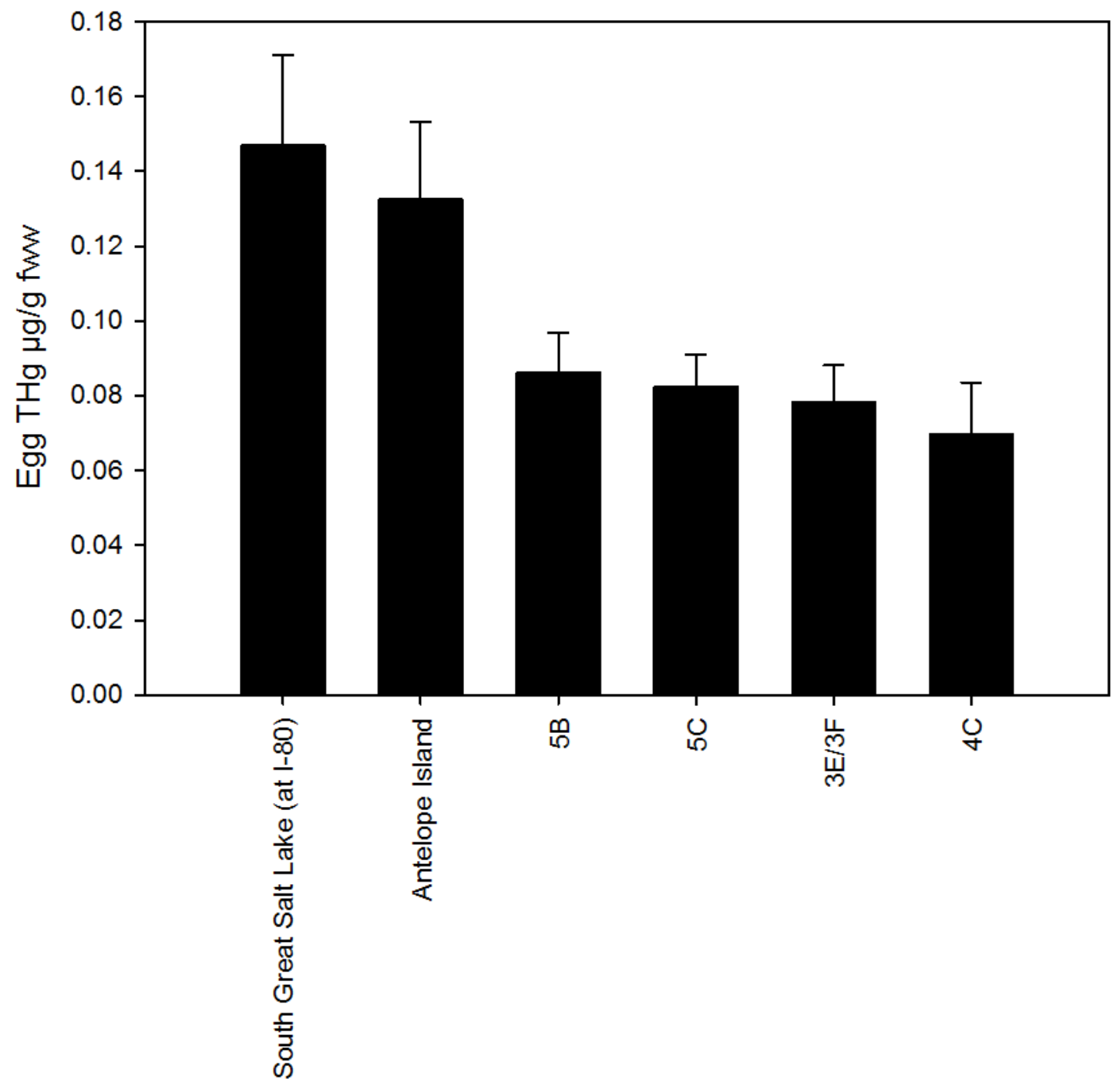

Wetland Site

Figure 12. Total mercury concentrations ( $\mu \mathrm{g} / \mathrm{g} \mathrm{fww}$ ) in eggs of California gulls breeding in various wetland sites within Great Salt Lake, Utah, 2010-2012. Values are least squares means \pm standard errors from a global model accounting for wetland site nested with region, region, year, and nest initiation date. Wetland sites with specific names occur within the Bear River Migratory Bird Refuge. 


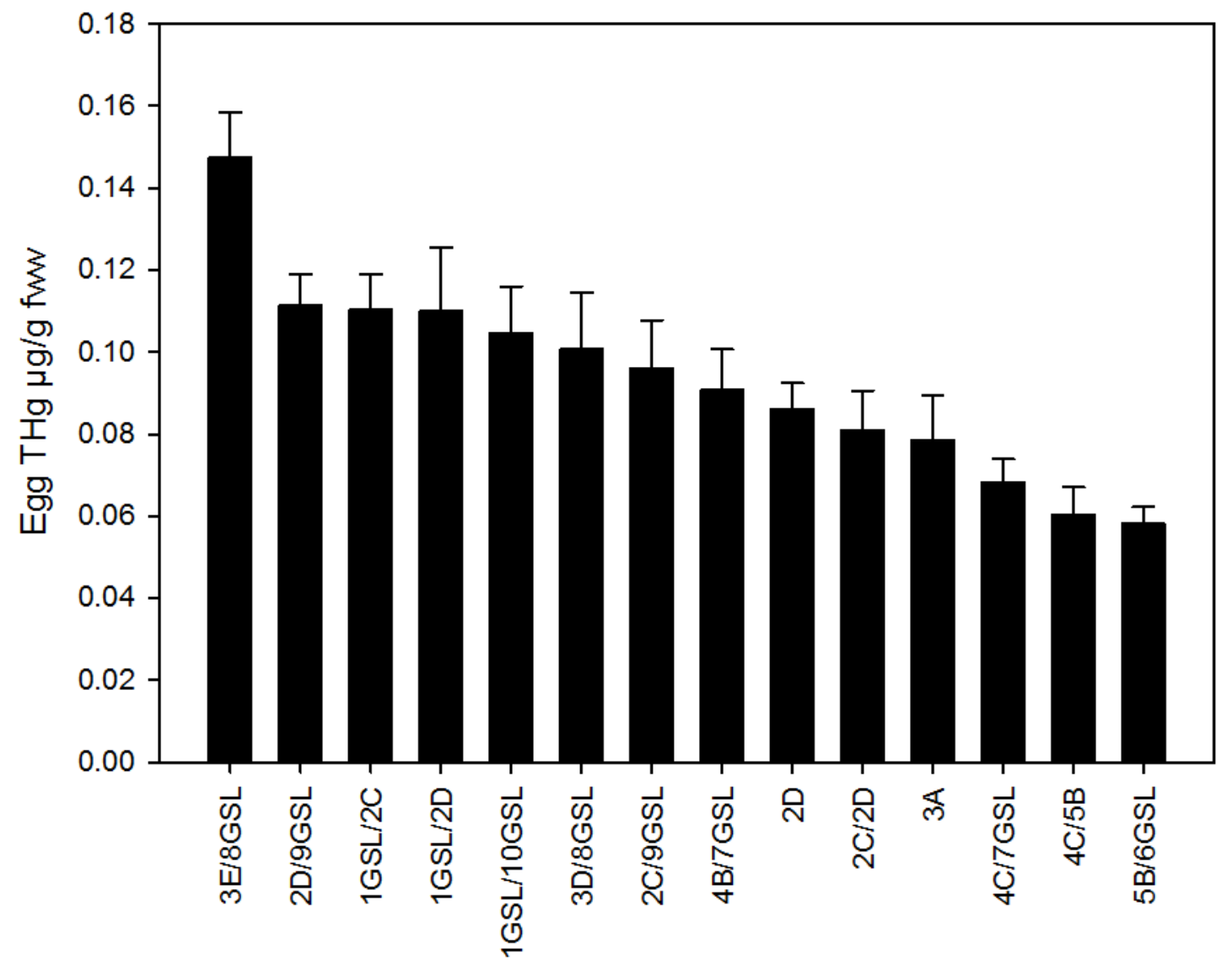

Wetland Site

Figure 13. Total mercury concentrations ( $\mu \mathrm{g} / \mathrm{g}$ fww) in eggs of cliff swallows breeding in various wetland sites within Great Salt Lake, Utah, 2010-2012. Values are least squares means \pm standard errors from a global model accounting for wetland site nested with region, region, year, and nest initiation date. Wetland sites with specific names occur within the Bear River Migratory Bird Refuge. 


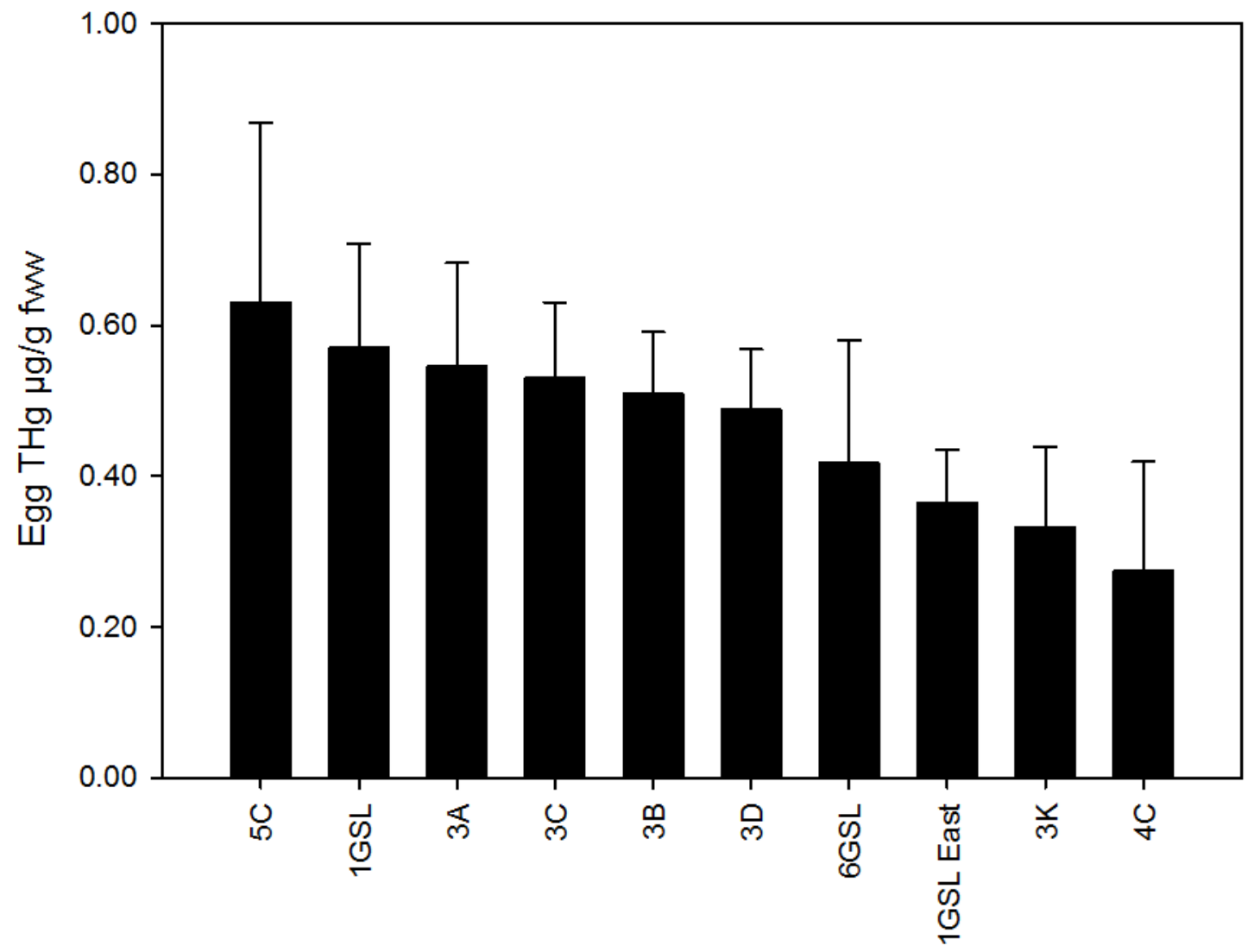

Wetland Site

Figure 14. Total mercury concentrations ( $\mu \mathrm{g} / \mathrm{g}$ fww) in eggs of Forster's terns breeding in various wetland sites within Great Salt Lake, Utah, 2010-2012. Values are least squares means \pm standard errors from a global model accounting for wetland site nested with region, region, year, and nest initiation date. Wetland sites with specific names occur within the Bear River Migratory Bird Refuge. 


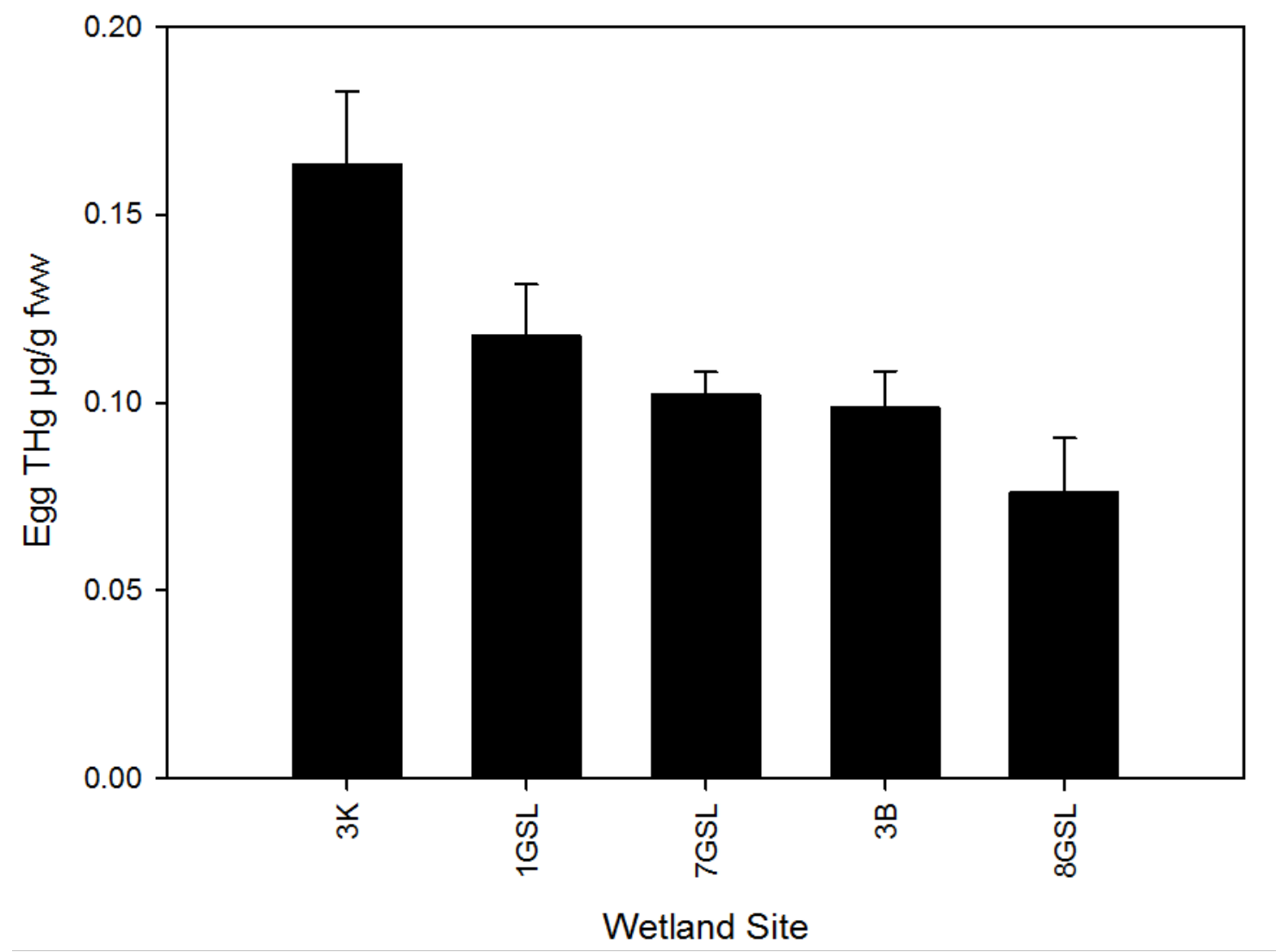

Figure 15. Total mercury concentrations ( $\mu \mathrm{g} / \mathrm{g}$ fww) in eggs of Franklin's gulls breeding in various wetland sites within Great Salt Lake, Utah, 2010-2012. Values are least squares means \pm standard errors from a global model accounting for wetland site nested with region, region, year, and nest initiation date. Wetland sites with specific names occur within the Bear River Migratory Bird Refuge. 


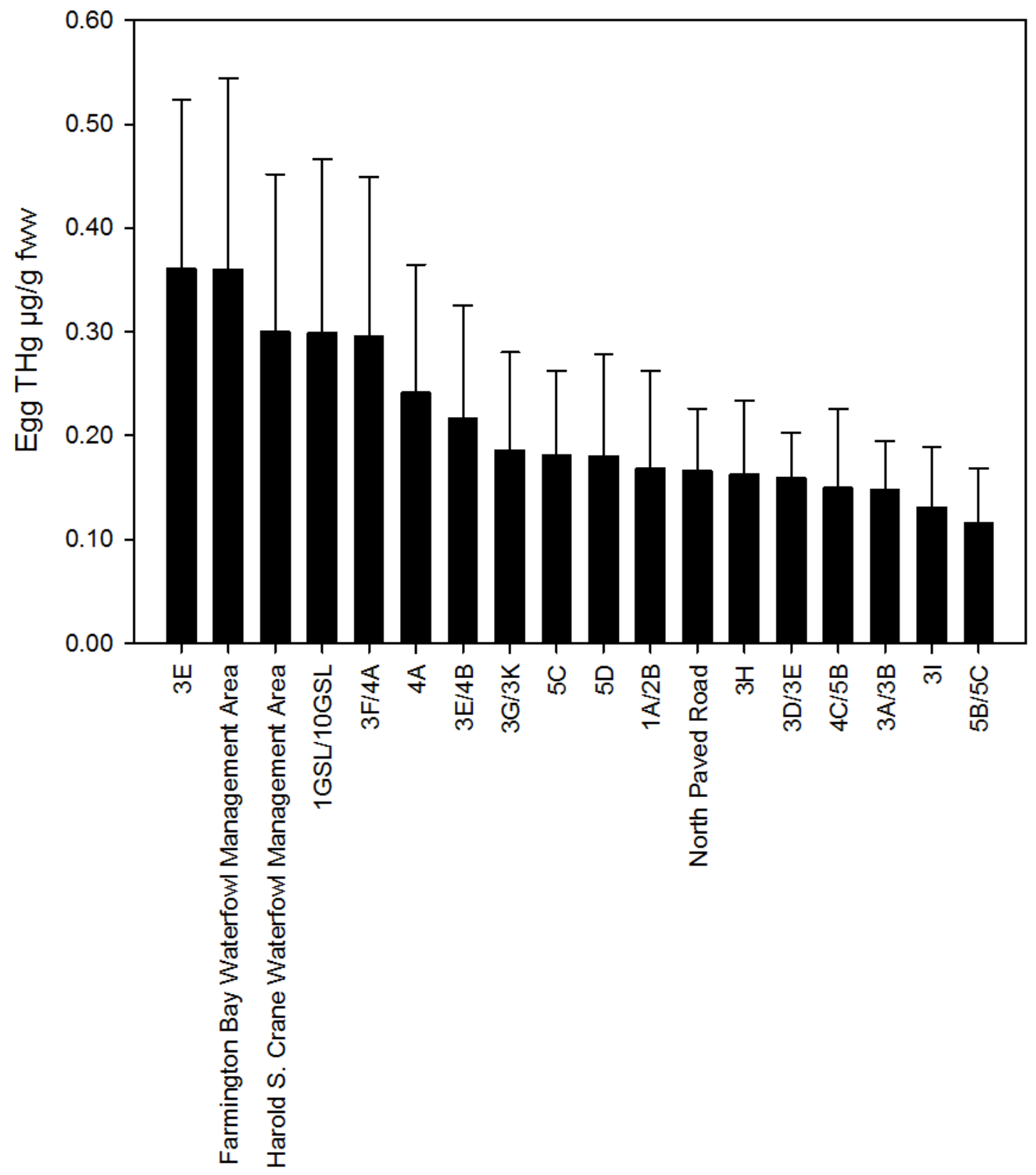

Wetland Site

Figure 16. Total mercury concentrations $(\mu \mathrm{g} / \mathrm{g} \mathrm{fww})$ in eggs of killdeer breeding in various wetland sites within Great Salt Lake, Utah, 2010-2012. Values are least squares means \pm standard errors from a global model accounting for wetland site nested with region, region, year, and nest initiation date. Wetland sites with specific names occur within the Bear River Migratory Bird Refuge. 


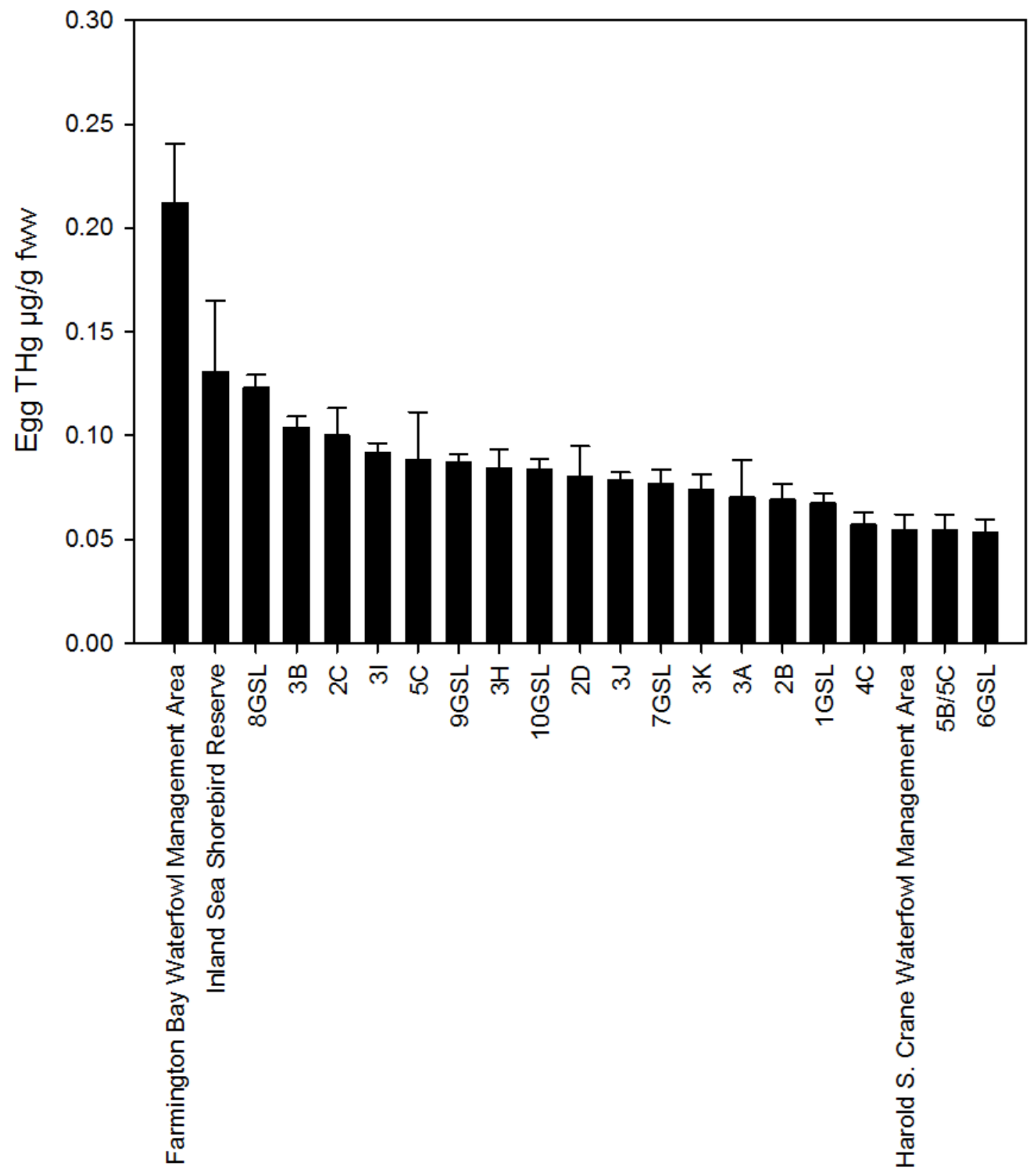

Wetland Site

Figure 17. Total mercury concentrations $(\mu \mathrm{g} / \mathrm{g} \mathrm{fww})$ in eggs of marsh wrens breeding in various wetland sites within Great Salt Lake, Utah, 2010-2012. Values are least squares means \pm standard errors from a global model accounting for wetland site nested with region, region, year, and nest initiation date. Wetland sites with specific names occur within the Bear River Migratory Bird Refuge. 


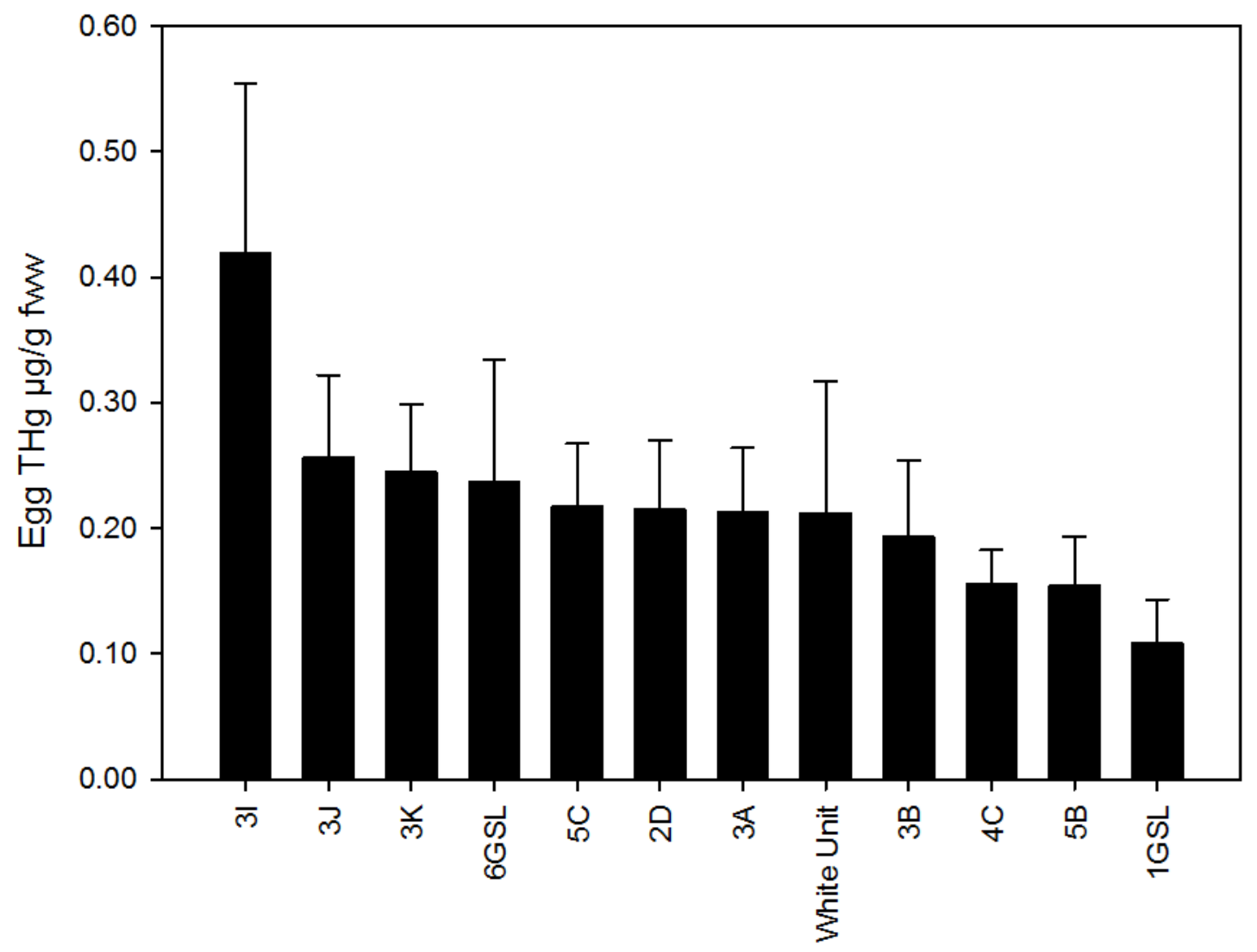

Wetland Site

Figure 18. Total mercury concentrations $(\mu \mathrm{g} / \mathrm{g} \mathrm{fww})$ in eggs of pied-billed grebes breeding in various wetland sites within Great Salt Lake, Utah, 2010-2012. Values are least squares means \pm standard errors from a global model accounting for wetland site nested with region, region, year, and nest initiation date. Wetland sites with specific names occur within the Bear River Migratory Bird Refuge. 


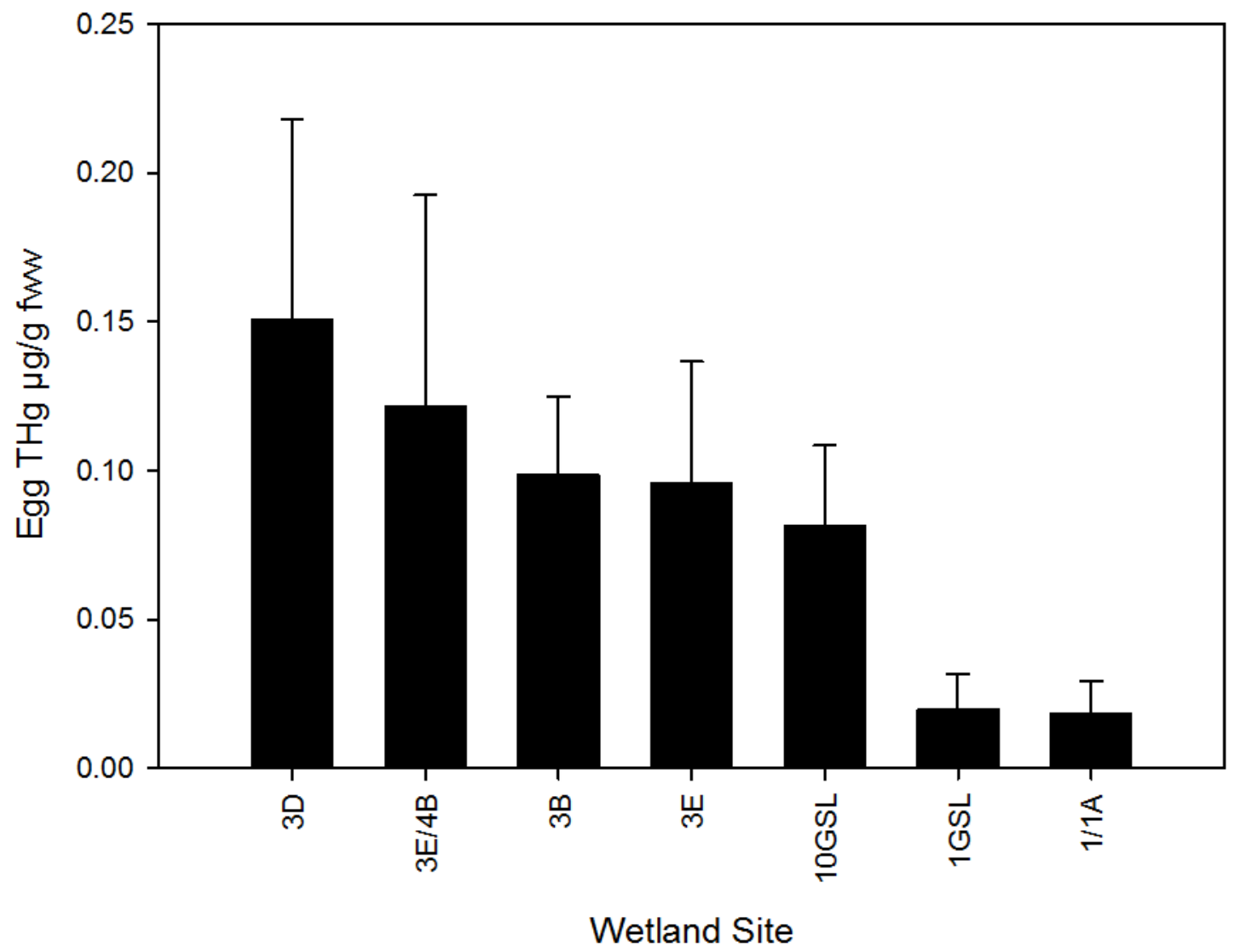

Figure 19. Total mercury concentrations ( $\mu \mathrm{g} / \mathrm{g} \mathrm{fww})$ in eggs of redhead ducks breeding in various wetland sites within Great Salt Lake, Utah, 2010-2012. Values are least squares means \pm standard errors from a global model accounting for wetland site nested with region, region, year, and nest initiation date. Wetland sites with specific names occur within the Bear River Migratory Bird Refuge. 


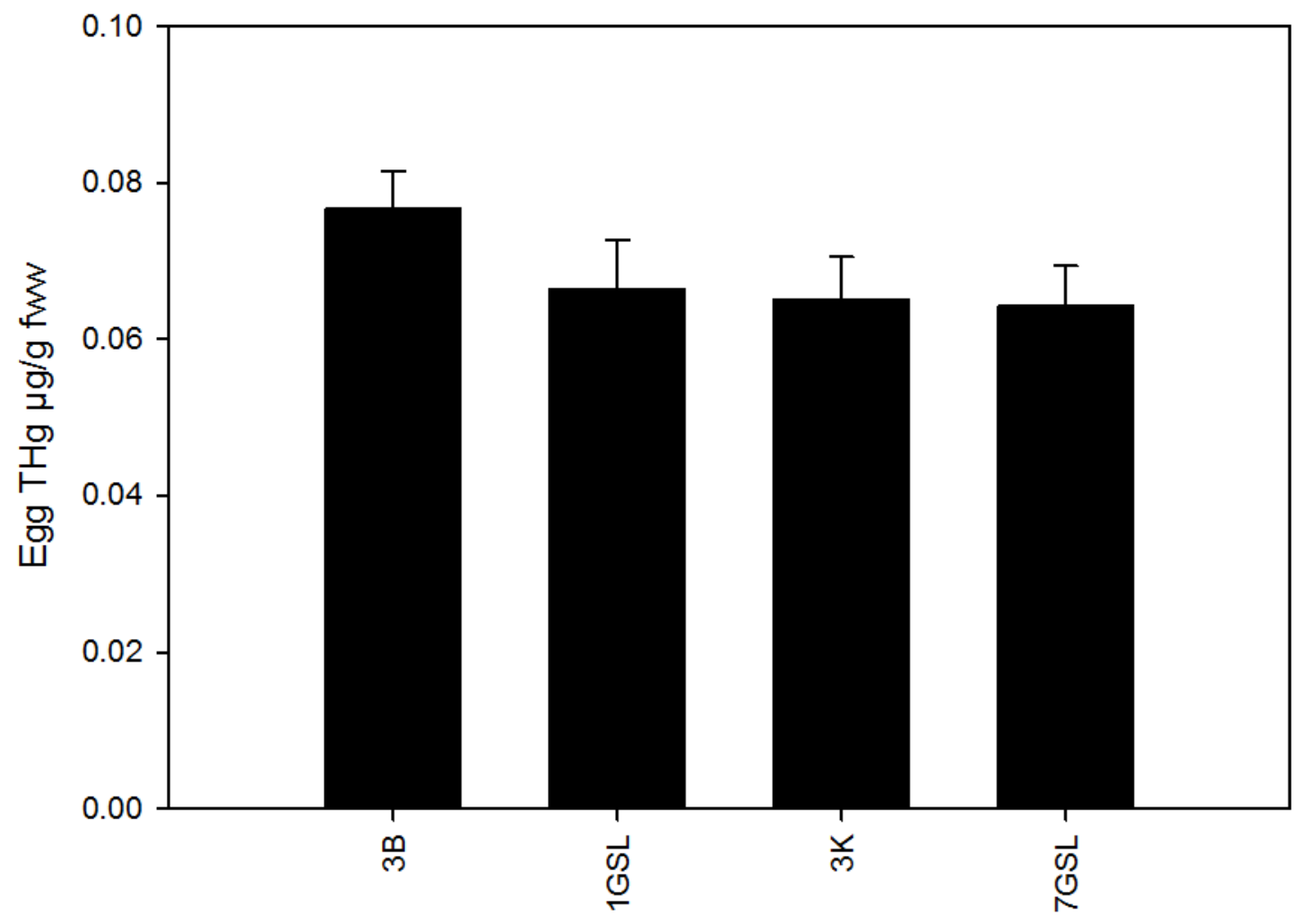

Wetland Site

Figure 20. Total mercury concentrations ( $\mu \mathrm{g} / \mathrm{g} \mathrm{fww}$ ) in eggs of white-faced ibis breeding in various wetland sites within Great Salt Lake, Utah, 2010-2012. Values are least squares means \pm standard errors from a global model accounting for wetland site nested with region, region, year, and nest initiation date. Wetland sites with specific names occur within the Bear River Migratory Bird Refuge. 


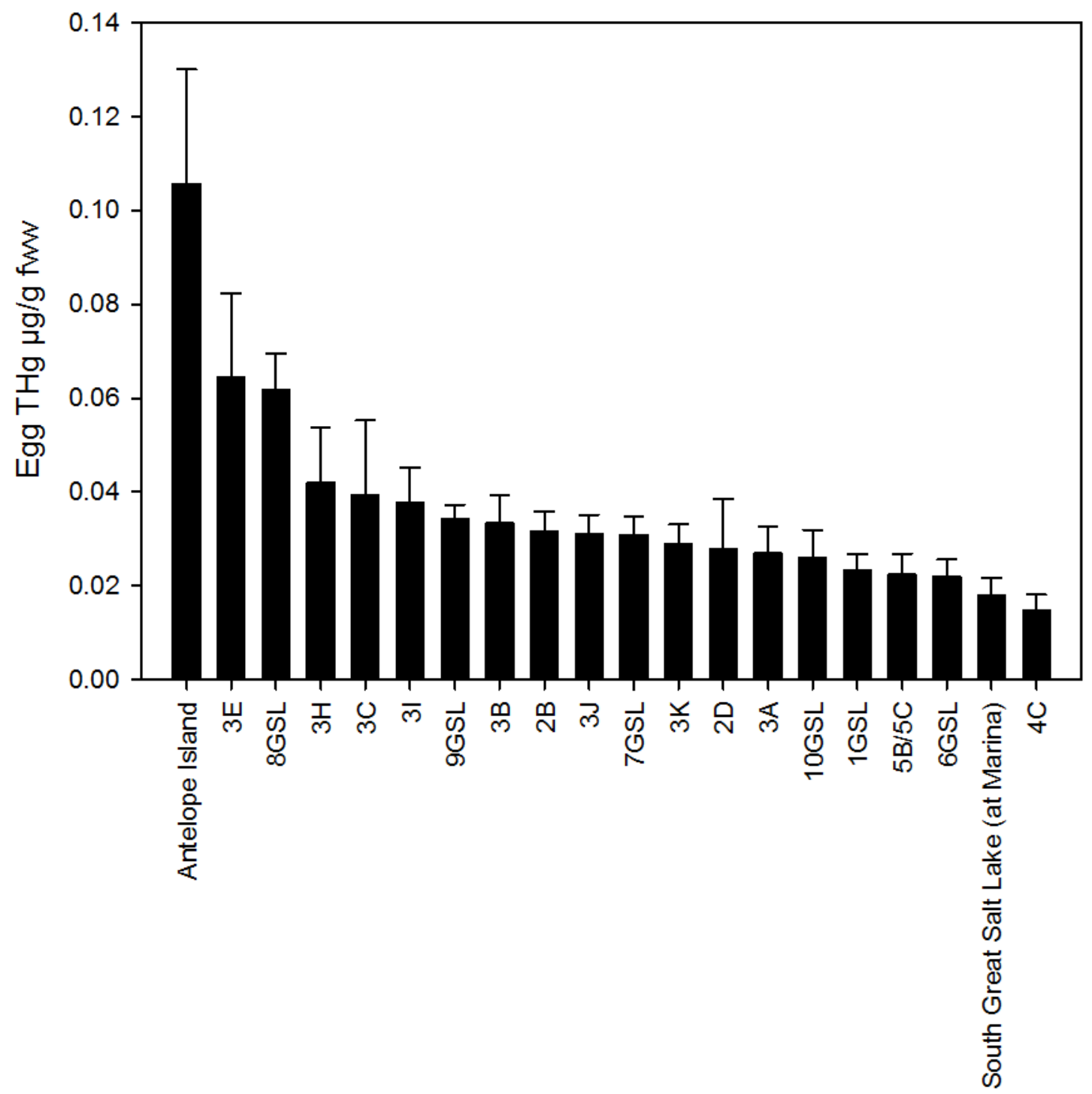

Wetland Site

Figure 21. Total mercury concentrations ( $\mu \mathrm{g} / \mathrm{g}$ fww) in eggs of yellow-headed blackbirds breeding in various wetland sites within Great Salt Lake, Utah, 2010-2012. Values are least squares means \pm standard errors from a global model accounting for wetland site nested with region, region, year, and nest initiation date. Wetland sites with specific names occur within the Bear River Migratory Bird Refuge. 


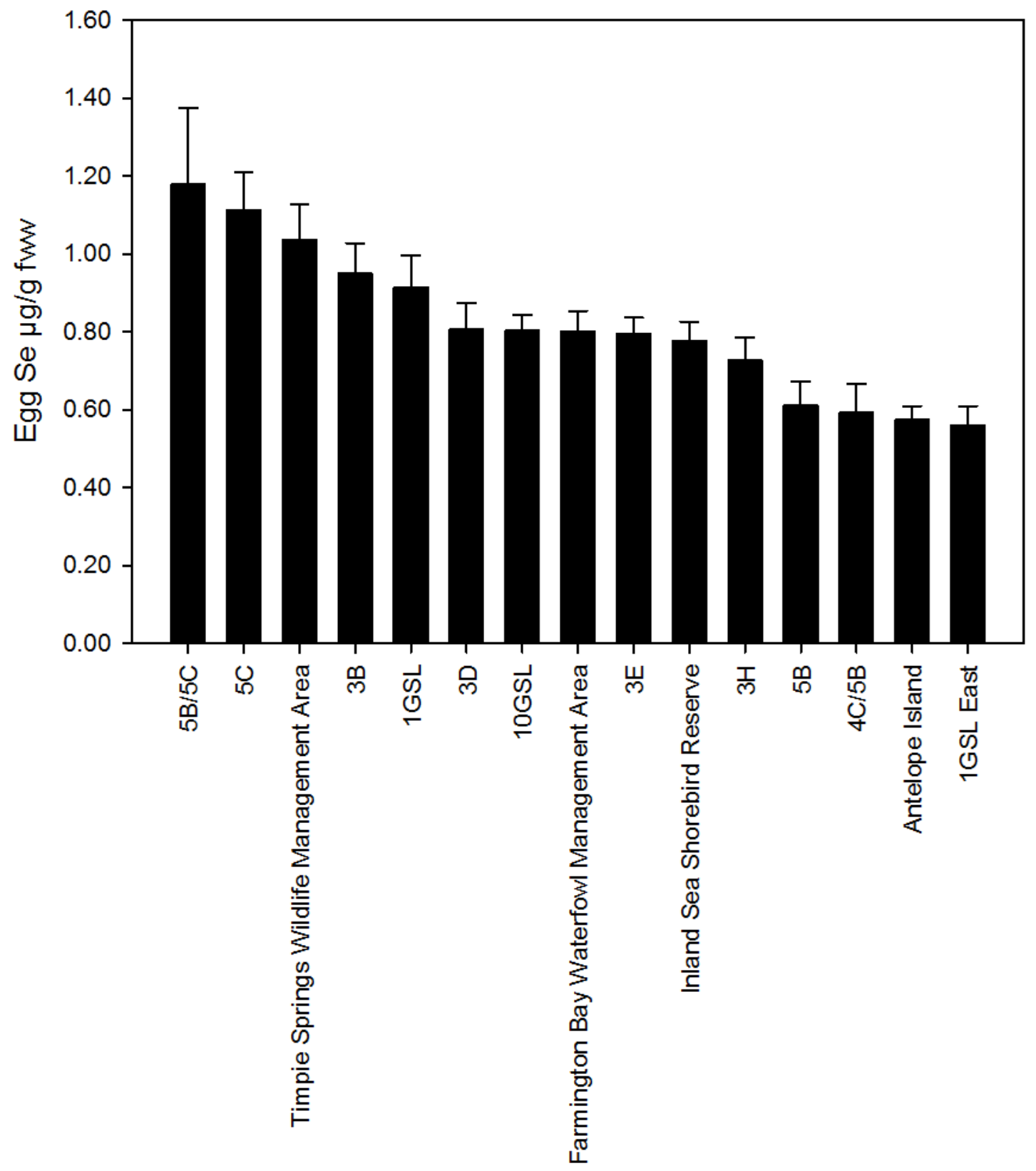

Wetland Site

Figure 22. Selenium concentrations ( $\mu \mathrm{g} / \mathrm{g} \mathrm{fww})$ in eggs of American avocets breeding in various wetland sites within Great Salt Lake, Utah, 2010-2012. Values are least squares means \pm standard errors from a global model accounting for wetland site and year. Wetland sites with specific names occur within the Bear River Migratory Bird Refuge. 


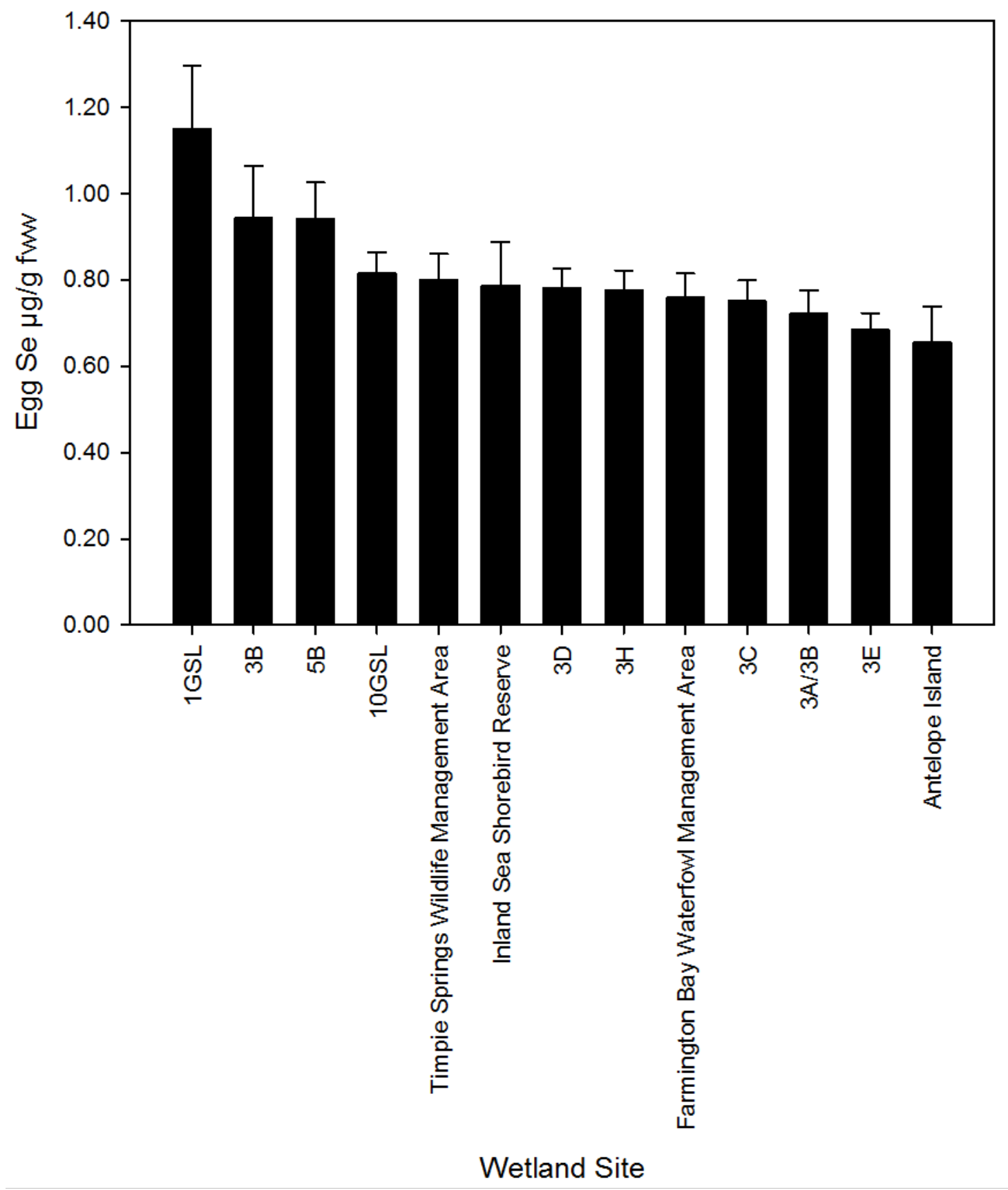

Figure 23. Selenium concentrations ( $\mu \mathrm{g} / \mathrm{g} \mathrm{fww}$ ) in eggs of black-necked stilts breeding in various wetland sites within Great Salt Lake, Utah, 2010-2012. Values are least squares means \pm standard errors from a global model accounting for wetland site and year. Wetland sites with specific names occur within the Bear River Migratory Bird Refuge. 


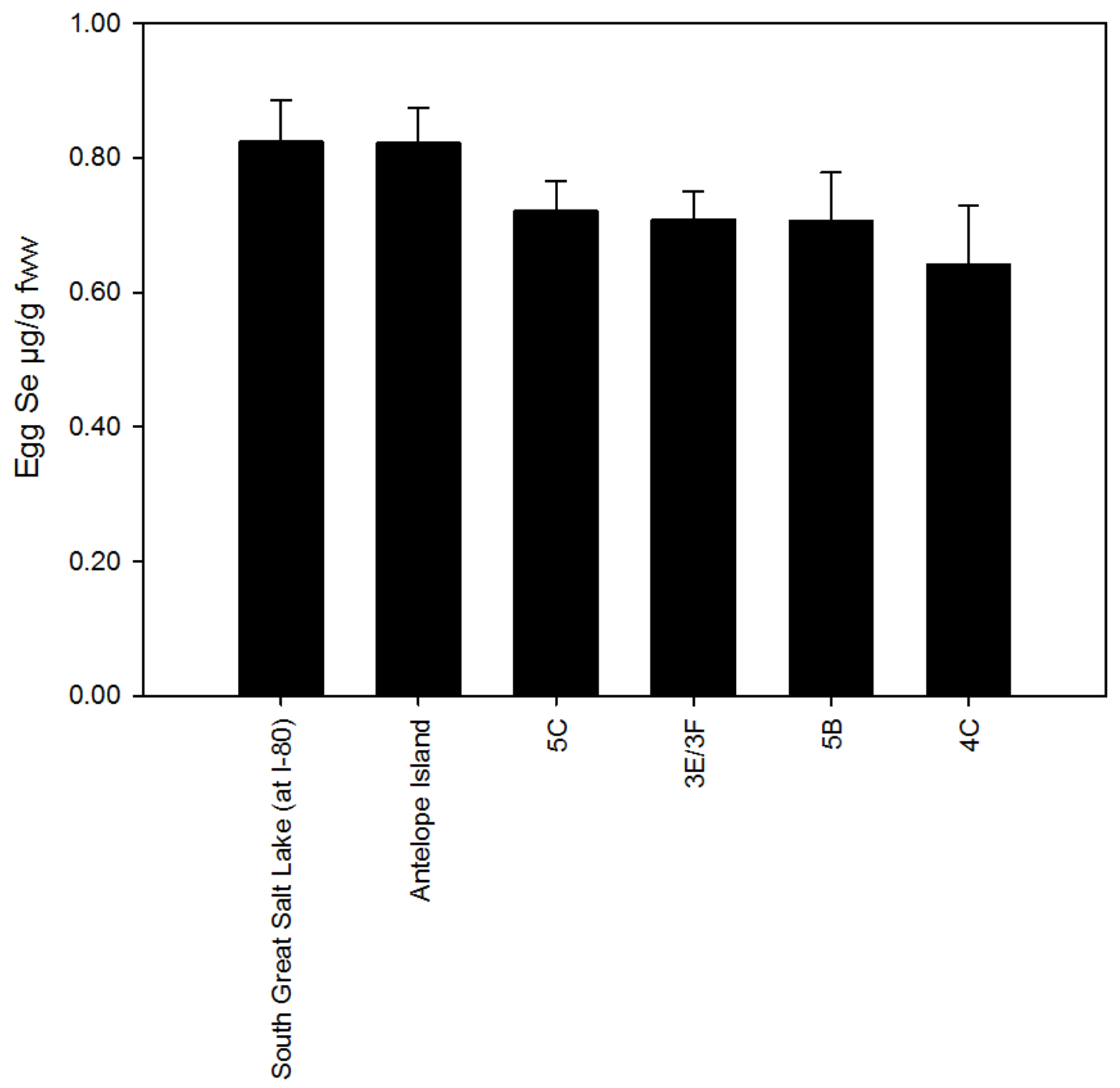

\section{Wetland Site}

Figure 24. Selenium concentrations ( $\mu \mathrm{g} / \mathrm{g} \mathrm{fww})$ in eggs of California gull breeding in various wetland sites within Great Salt Lake, Utah, 2010-2012. Values are least squares means \pm standard errors from a global model accounting for wetland site and year. Wetland sites with specific names occur within the Bear River Migratory Bird Refuge. 


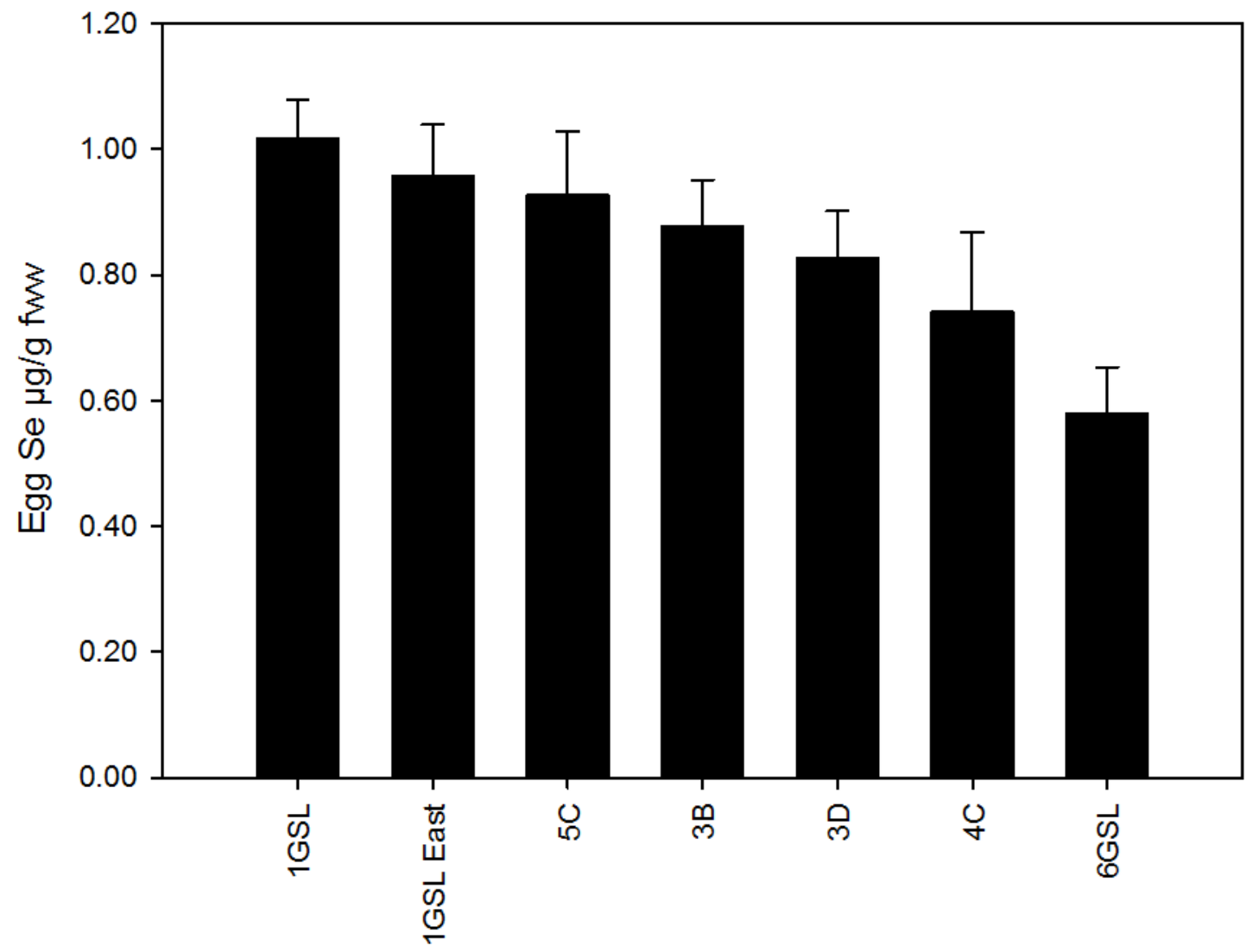

Wetland Site

Figure 25. Selenium concentrations ( $\mu \mathrm{g} / \mathrm{g} \mathrm{fww})$ in eggs of Forster's terns breeding in various wetland sites within Great Salt Lake, Utah, 2010-2012. Values are least squares means \pm standard errors from a global model accounting for wetland site and year. Wetland sites with specific names occur within the Bear River Migratory Bird Refuge. 


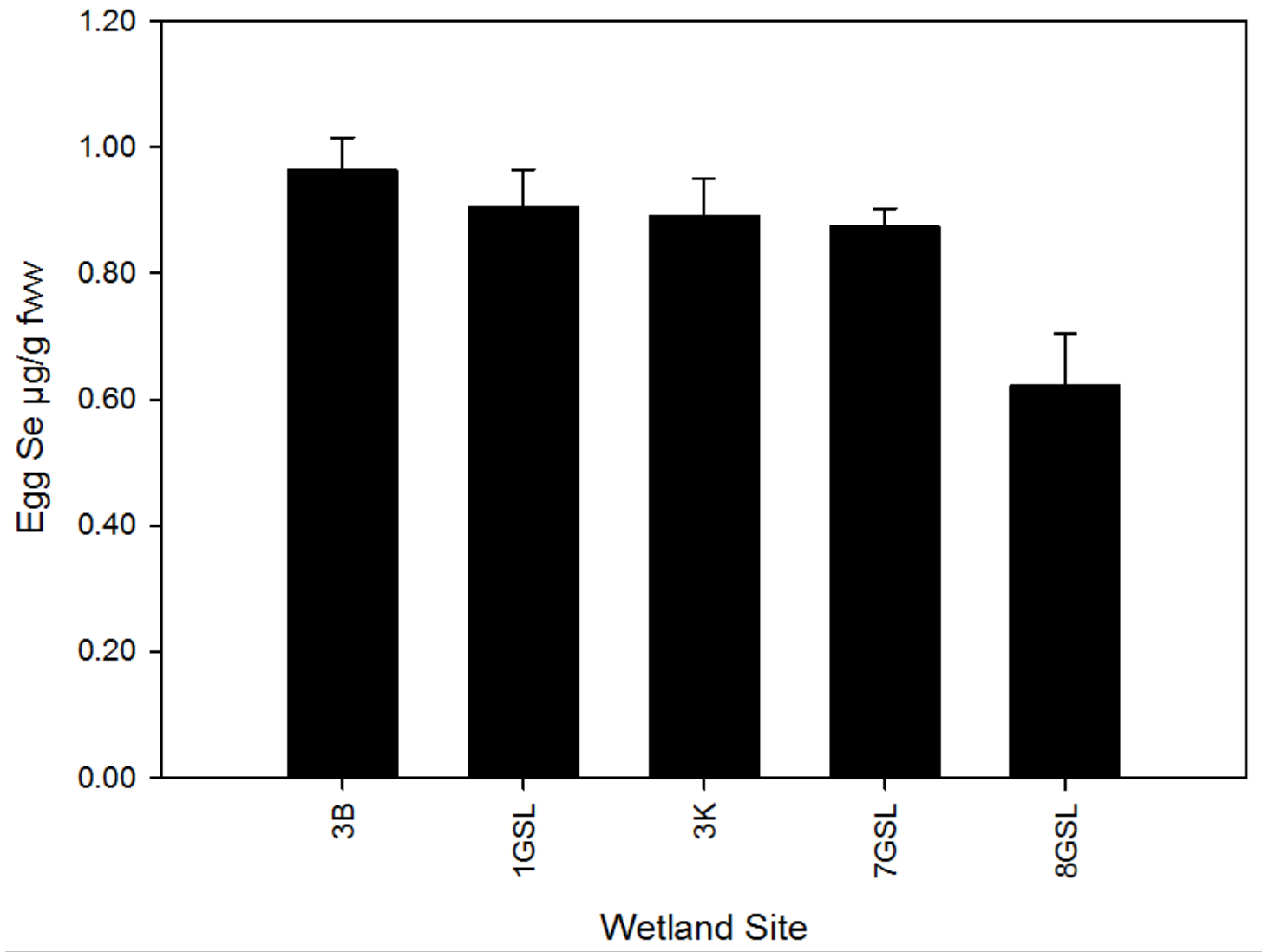

Figure 26. Selenium concentrations ( $\mu \mathrm{g} / \mathrm{g} \mathrm{fww}$ ) in eggs of Franklin's gulls breeding in various wetland sites within Great Salt Lake, Utah, 2010-2012. Values are least squares means \pm standard errors from a global model accounting for wetland site and year. Wetland sites with specific names occur within the Bear River Migratory Bird Refuge. 


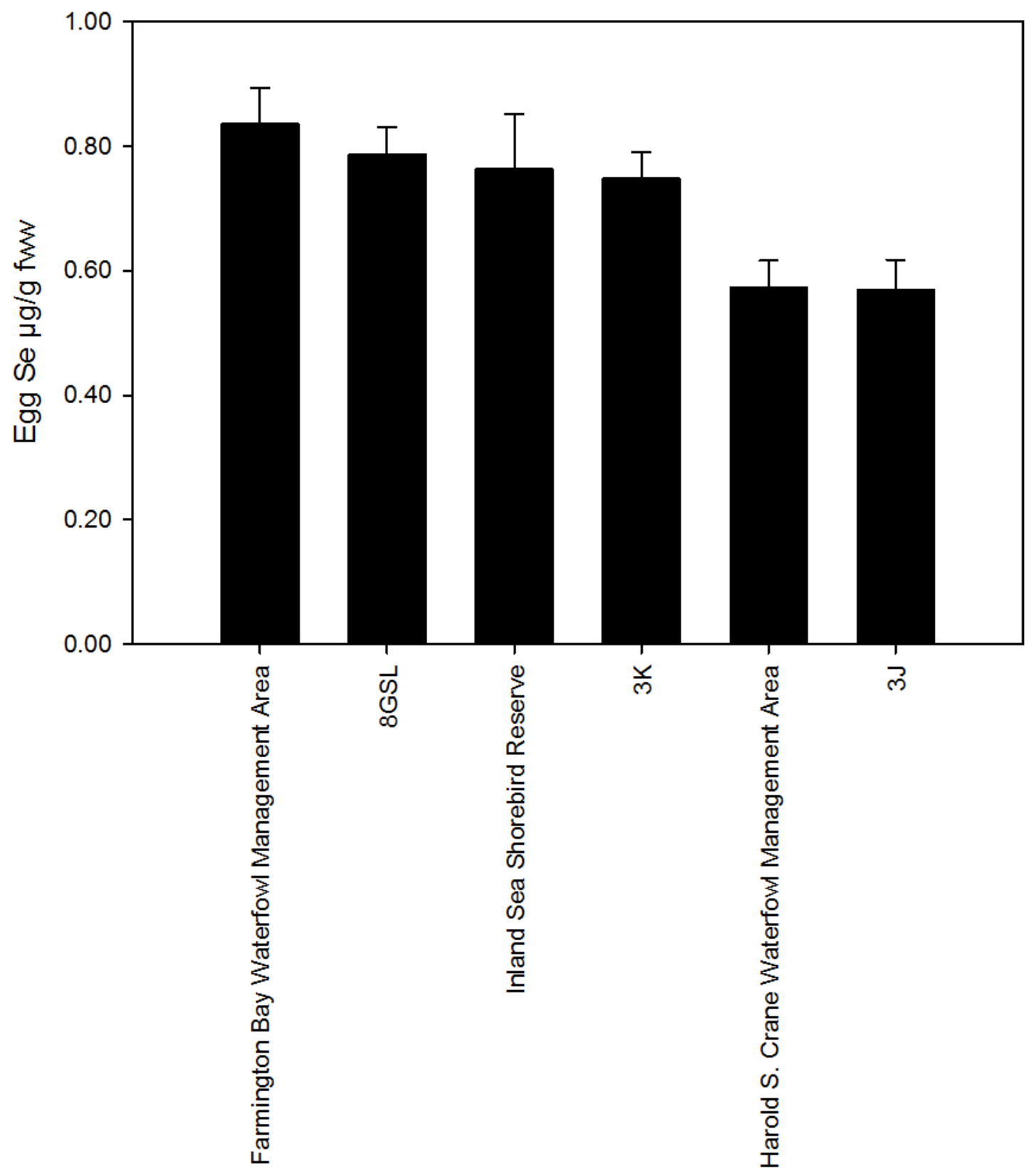

Wetland Site

Figure 27. Selenium concentrations ( $\mu \mathrm{g} / \mathrm{g} \mathrm{fww})$ in eggs of marsh wrens breeding in various wetland sites within Great Salt Lake, Utah, 2010-2012. Values are least squares means \pm standard errors from a global model accounting for wetland site and year. Wetland sites with specific names occur within the Bear River Migratory Bird Refuge. 


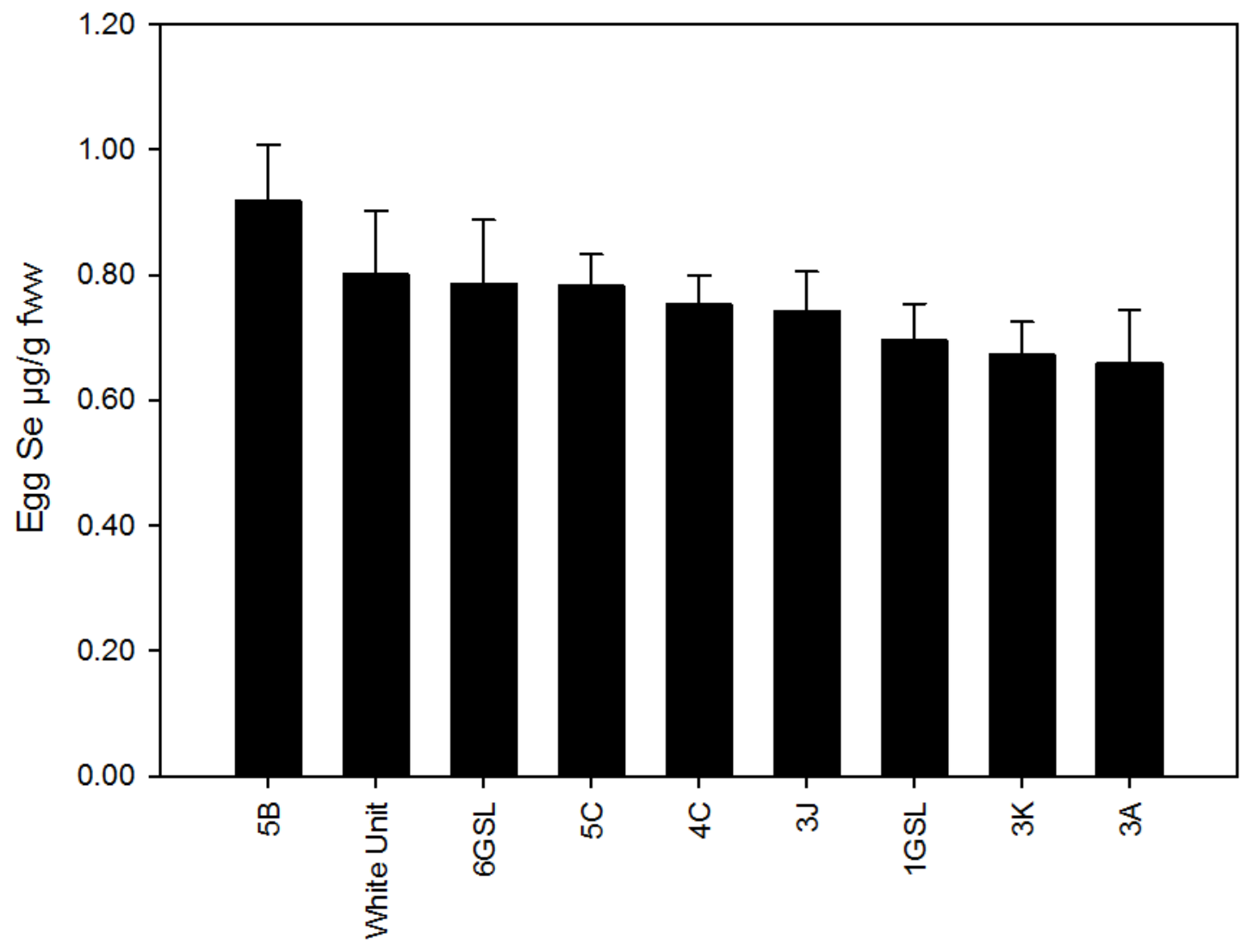

Wetland Site

Figure 28. Selenium concentrations $(\mu \mathrm{g} / \mathrm{g} \mathrm{fww})$ in eggs of pied-billed grebes breeding in various wetland sites within Great Salt Lake, Utah, 2010-2012. Values are least squares means \pm standard errors from a global model accounting for wetland site and year. Wetland sites with specific names occur within the Bear River Migratory Bird Refuge. 


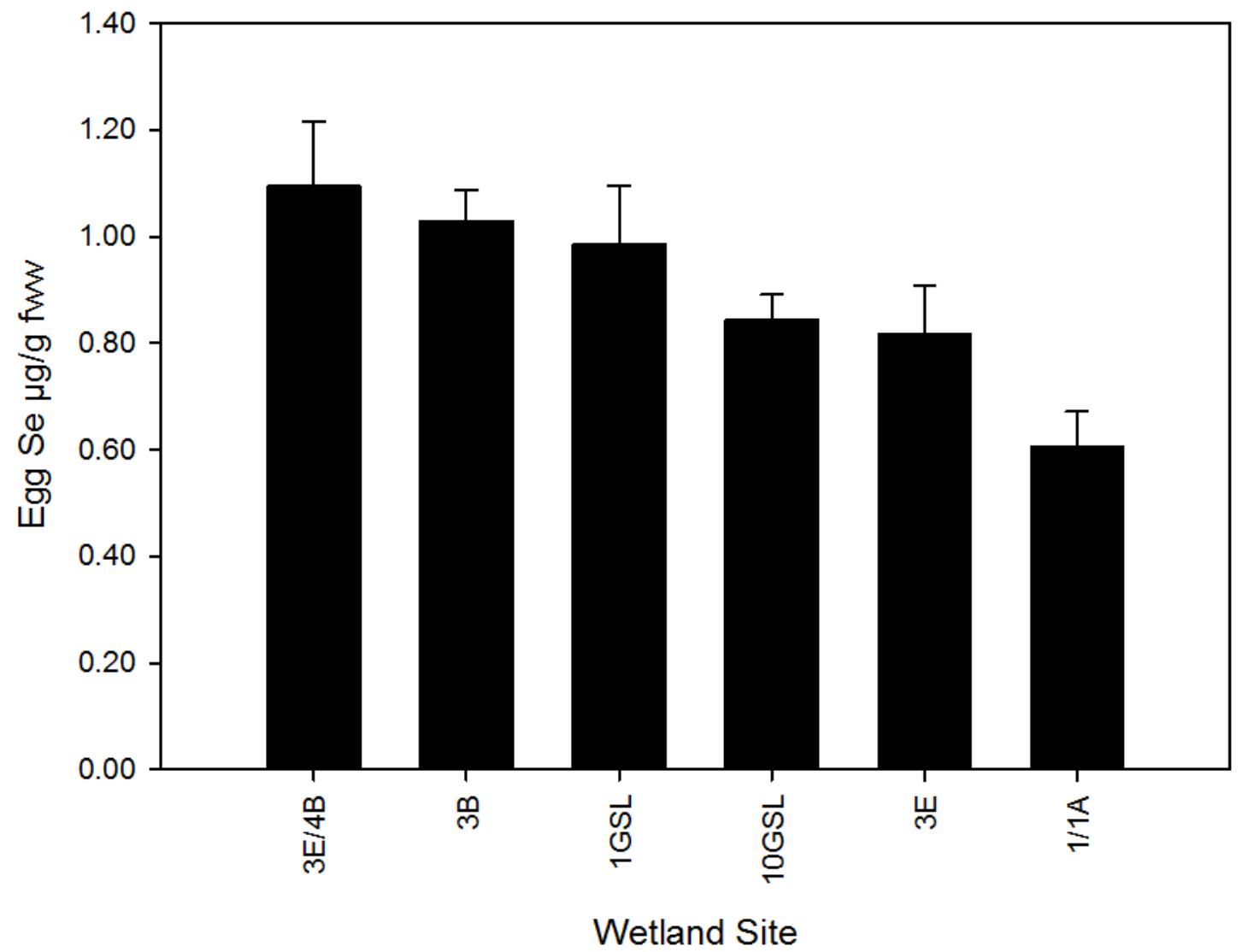

Figure 29. Selenium concentrations ( $\mu \mathrm{g} / \mathrm{g} \mathrm{fww}$ ) in eggs of redhead ducks breeding in various wetland sites within Great Salt Lake, Utah, 2010-2012. Values are least squares means \pm standard errors from a global model accounting for wetland site and year. Wetland sites with specific names occur within the Bear River Migratory Bird Refuge. 


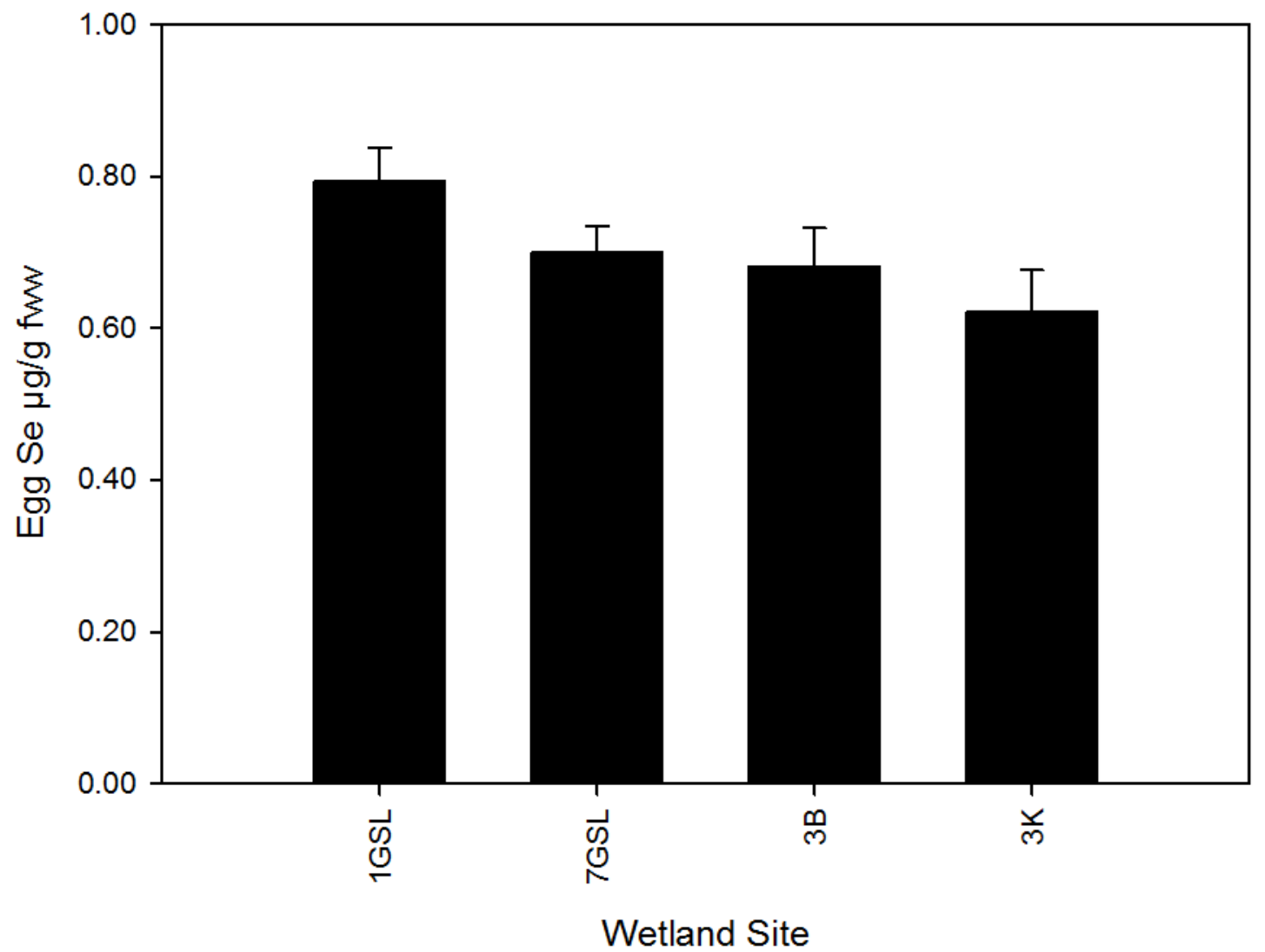

Figure 30. Selenium concentrations ( $\mu \mathrm{g} / \mathrm{g} \mathrm{fww})$ in eggs of white-faced ibis breeding in various wetland sites within Great Salt Lake, Utah, 2010-2012. Values are least squares means \pm standard errors from a global model accounting for wetland site and year. Wetland sites with specific names occur within the Bear River Migratory Bird Refuge. 


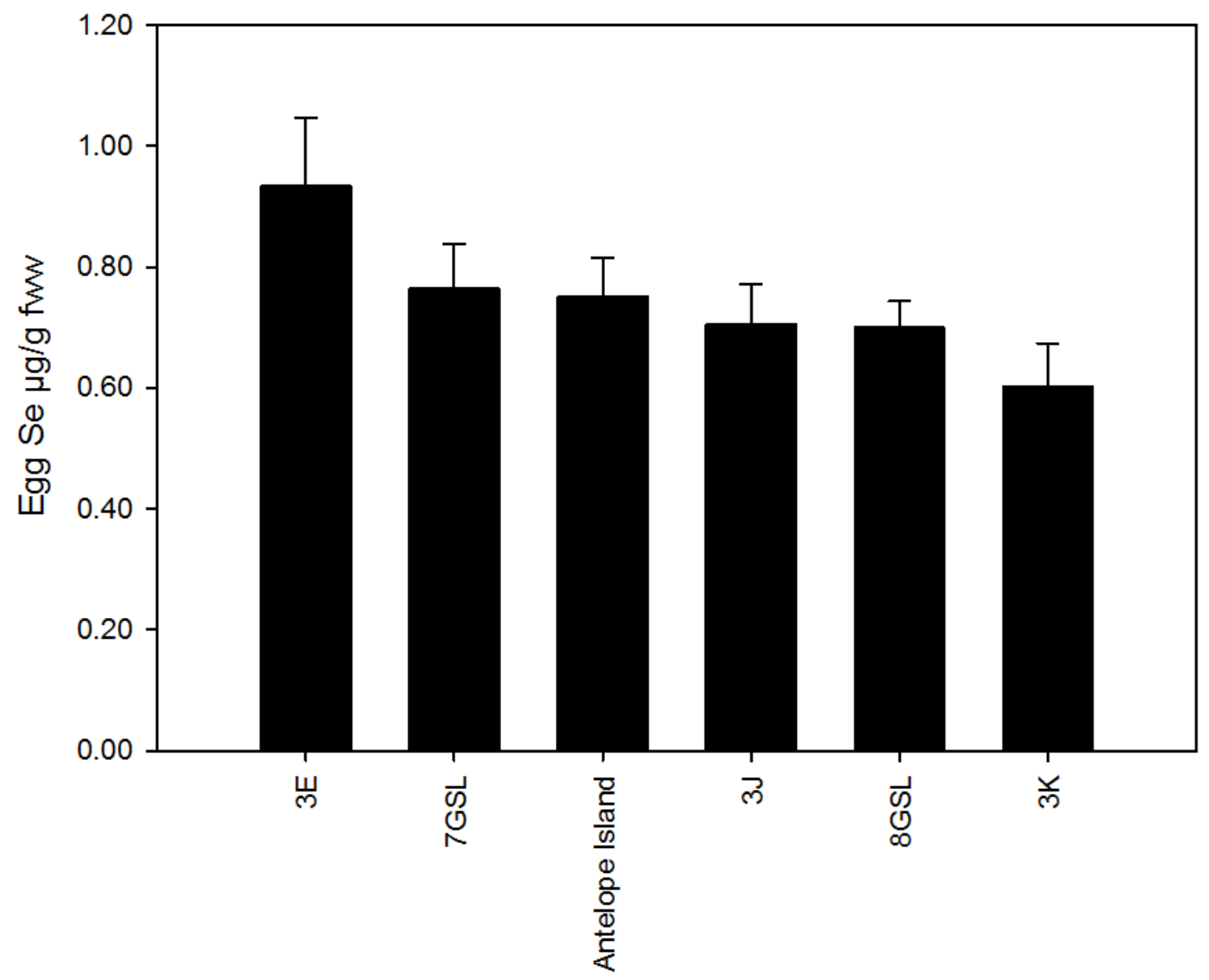

Wetland Site

Figure 31. Selenium concentrations ( $\mu \mathrm{g} / \mathrm{g} \mathrm{fww}$ ) in eggs of yellow-headed blackbirds breeding in various wetland sites within Great Salt Lake, Utah, 2010-2012. Values are least squares means \pm standard errors from a global model accounting for wetland site and year. Wetland sites with specific names occur within the Bear River Migratory Bird Refuge. 

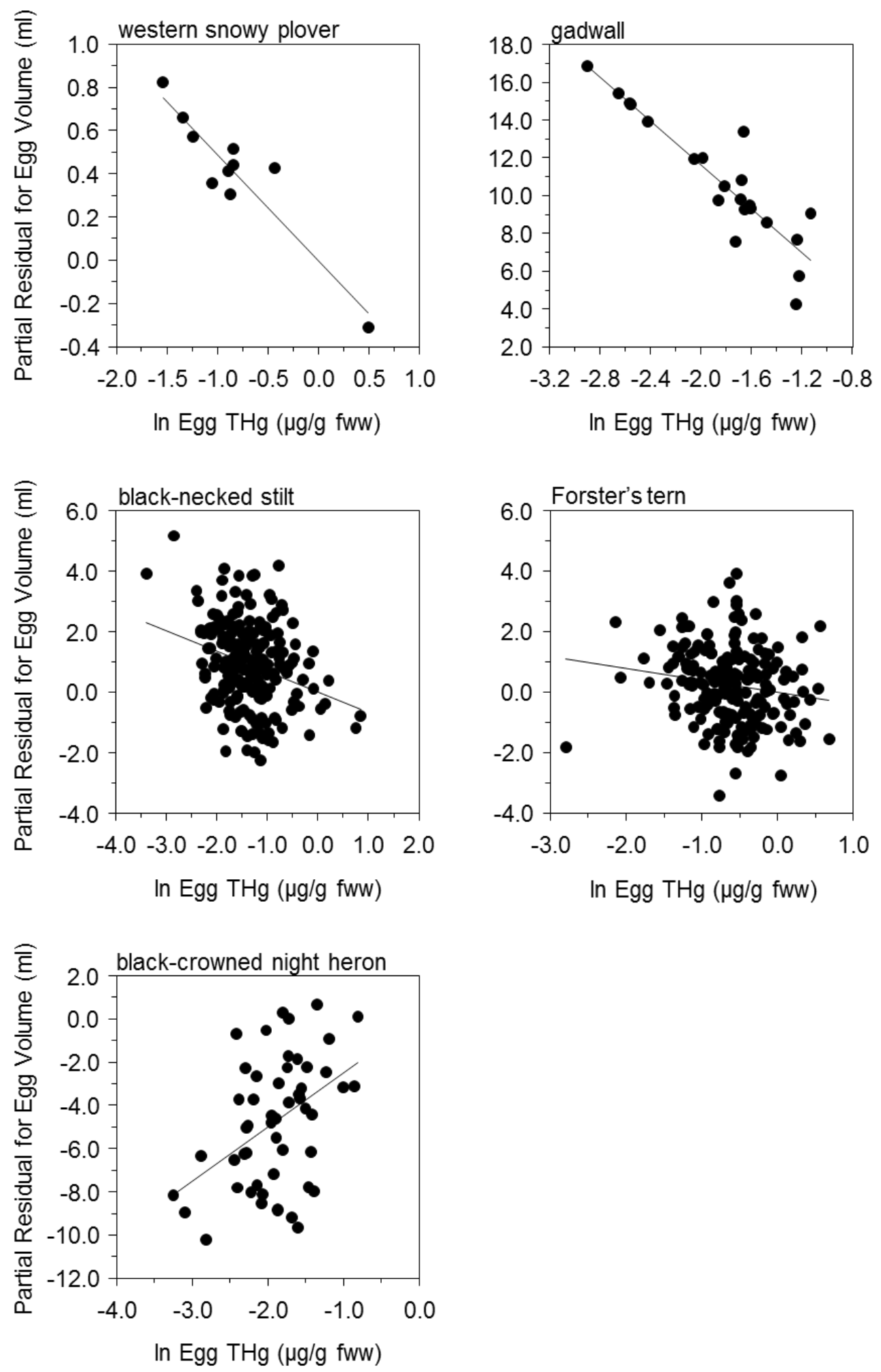

Figure 32. Egg volume in relation to natural log (In) transformed egg mercury concentrations ( $\mathrm{THg} \mu \mathrm{gg} / \mathrm{g}$ fww) in snowy plovers, gadwall, black-necked stilts, and Forster's terns, and increased with egg mercury concentrations in black-crowned night herons breeding in Great Salt Lake, Utah, 2010-2012. Partial residuals of egg volume accounted for the global model effects of wetland site, nest initiation date, and year. 

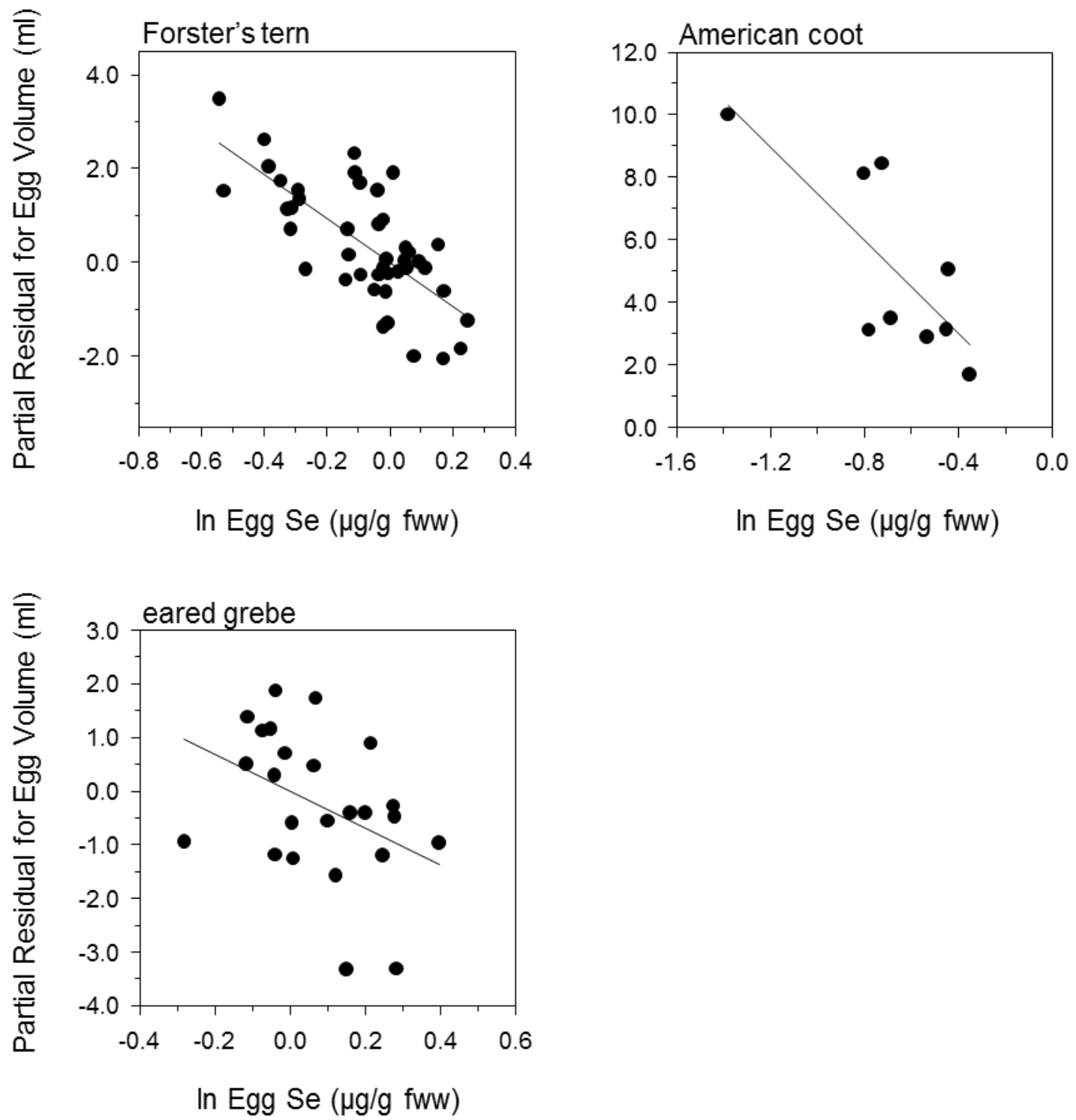

Figure 33. Egg volume in relation to natural $\log (\mathrm{In})$ transformed egg selenium concentrations (Se $\mu \mathrm{g} / \mathrm{g} \mathrm{fww}$ ) in Forster's terns, American coots, and eared grebes breeding in Great Salt Lake, Utah, 2010-2011. Partial residuals of egg volume accounted for the global model effects of wetland site, nest initiation date, and year. 


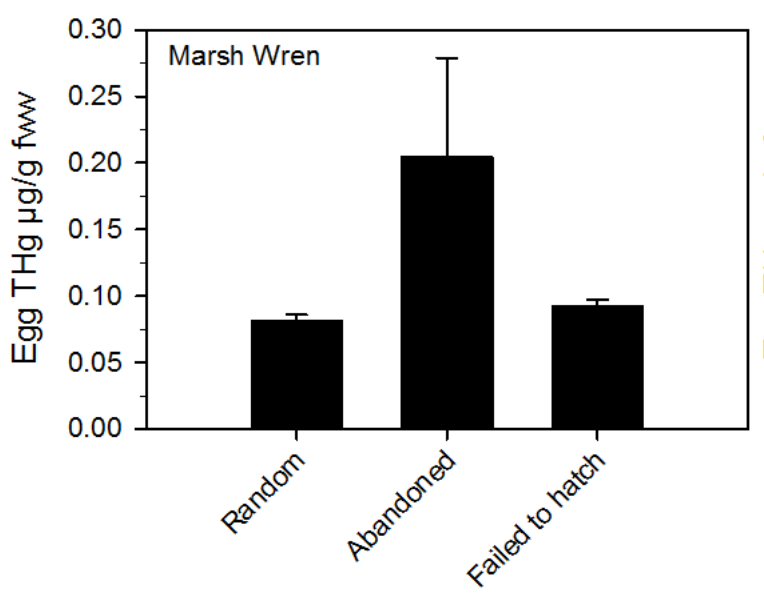

Egg Type

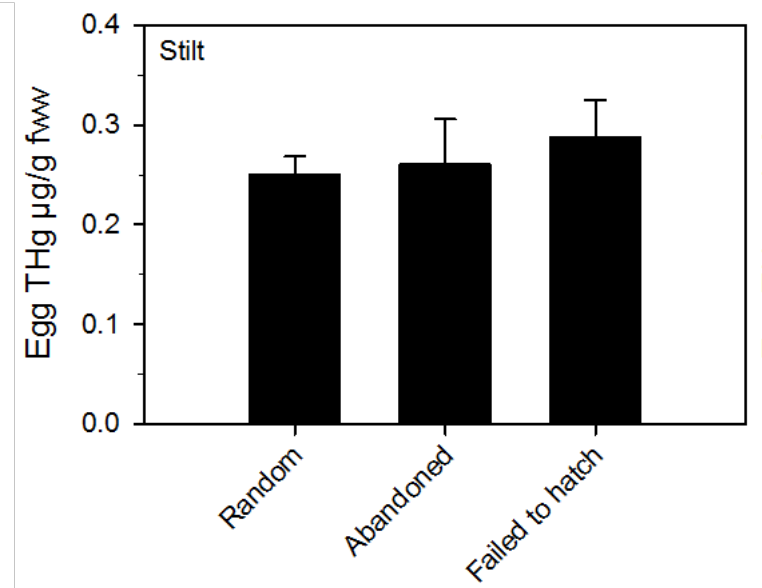

Egg Type

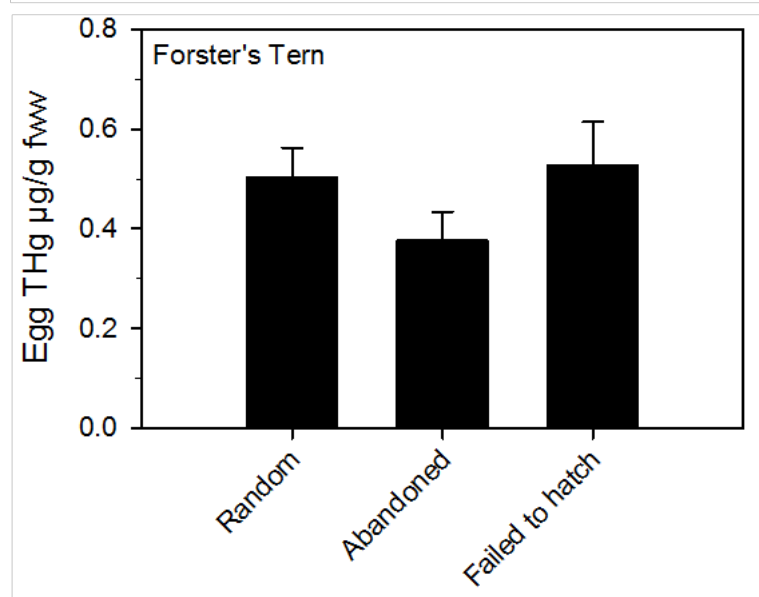

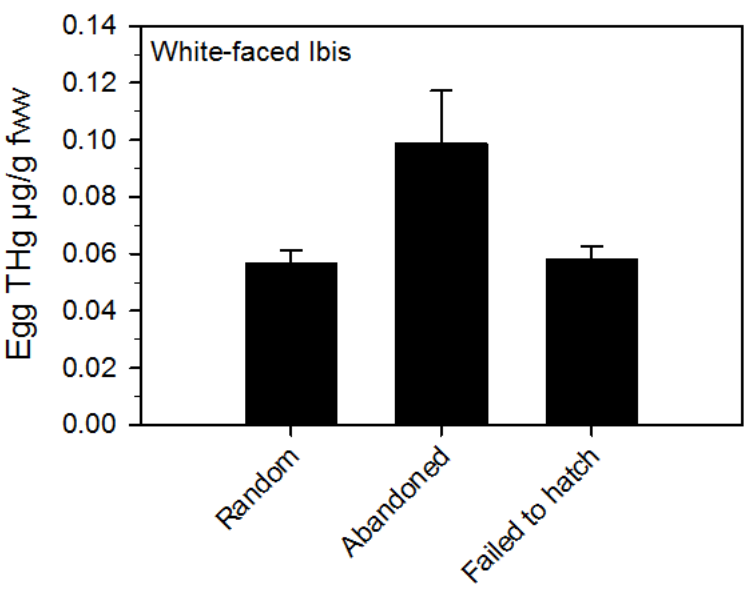

Egg Type

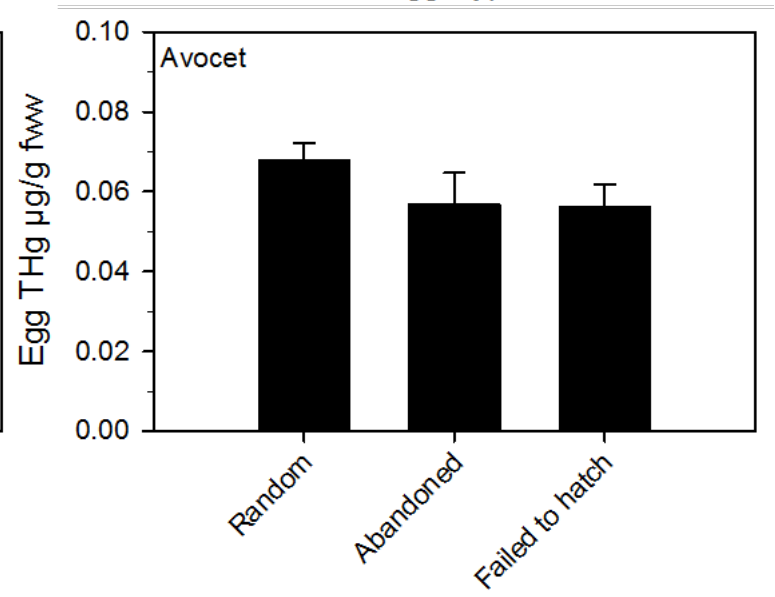

Egg Type

Egg Type

Figure 34. Total mercury concentrations ( $\mathrm{THg} \mu \mathrm{g} / \mathrm{g}$ fww; least squares means \pm standard error) in randomly sampled eggs from successful nests (random), naturally abandoned eggs (abandoned), and failed to hatch eggs in nests where at least one other egg in the clutch successfully hatched (failed to hatch) for 5 species of birds breeding at Bear River Migratory Bird Refuge in Great Salt Lake, Utah, 2012. Least squares means accounted for the global model effects of egg type and site for each species. 
Table 1. Common, scientific, and short names for 33 species of birds studied that nested in Great Salt Lake, Utah, 2010-2012.

\begin{tabular}{|c|c|c|}
\hline $\begin{array}{c}\text { American } \\
\text { Ornithologist's } \\
\text { Union Code }\end{array}$ & Common Name & Scientific Name \\
\hline AMAV & American avocet & Recurvirostra americana \\
\hline $\mathrm{AMCO}$ & American coot & Fulica americana \\
\hline BARS & barn swallow & Hirundo rustica \\
\hline $\mathrm{BCNH}$ & black-crowned night heron & Nycticorax nycticorax \\
\hline $\mathrm{BHCO}$ & brown-headed cowbird & Molothrus ater \\
\hline BNST & black-necked stilt & Himantopus mexicanus \\
\hline CAGO & Canada goose & Branta canadensis \\
\hline CAGU & California gull & Larus californicus \\
\hline CATE & Caspian tern & Hydroprogne caspia \\
\hline CITE & cinnamon teal & Anas cyanoptera \\
\hline CLSW & cliff swallow & Petrochelidon pyrrhonota \\
\hline COYE & common yellowthroat & Geothlypis trichas \\
\hline $\mathrm{DCCO}$ & double-crested cormorant & Phalacrocorax auritus \\
\hline EAGR & eared grebe & Podiceps nigricollis \\
\hline FOTE & Forster's tern & Sterna forsteri \\
\hline FRGU & Franklin's gull & Leucophaeus pipixcan \\
\hline GADW & gadwall & Anas strepera \\
\hline GBHE & great blue heron & Ardea herodias \\
\hline GREG & great egret & Ardea alba \\
\hline KILL & killdeer & Charadrius vociferus \\
\hline MALL & mallard & Anas platyrhynchos \\
\hline MAWR & marsh wren & Cistothorus palustris \\
\hline NOPI & northern pintail & Anas acuta \\
\hline PBGR & pied-billed grebe & Podilymbus podiceps \\
\hline RBGU & ring-billed gull & Larus delawarensis \\
\hline REDH & redhead & Aythya americana \\
\hline RWBL & red-winged blackbird & Agelaius phoeniceus \\
\hline SNEG & snowy egret & Egretta thula \\
\hline SNPL & snowy plover & Charadrius nivosus \\
\hline WEGR & western grebe & Aechmophorus occidentalis \\
\hline WFIB & white-faced ibis & Plegadis chihi \\
\hline WIPH & Wilson's phalarope & Phalaropus tricolor \\
\hline YHBL & yellow-headed blackbird & Xanthocephalus xanthocephalus \\
\hline
\end{tabular}


Table 2. Correlations between selenium concentrations and total mercury concentrations ( $\mu \mathrm{g} / \mathrm{g} \mathrm{fww})$ in eggs from 32 bird species breeding in Great Salt Lake, Utah, 2010- 2011.

[Significant correlations are highlighted in gray]

\begin{tabular}{|c|c|c|c|c|c|}
\hline Species & N & $\mathbf{R}^{2}$ & $\mathbf{P}$ & Intercept & Slope \\
\hline American avocet & 88 & 0.04 & 0.07 & -0.10 & 0.08 \\
\hline American coot & 9 & 0.25 & 0.17 & 0.03 & 0.30 \\
\hline barn swallow & 11 & 0.23 & 0.14 & -0.25 & 0.14 \\
\hline black-crowned night heron & 21 & 0.04 & 0.37 & -0.20 & -0.06 \\
\hline brown-headed cowbird & 4 & 0.51 & 0.29 & -0.63 & 0.08 \\
\hline black-necked stilt & 39 & 0.14 & 0.02 & -0.15 & 0.09 \\
\hline Canada goose & 6 & 0.28 & 0.28 & -0.54 & 0.15 \\
\hline California gull & 49 & 0.17 & 0.004 & -0.01 & 0.12 \\
\hline Caspian tern & 27 & 0.02 & 0.44 & -0.52 & 0.10 \\
\hline cinnamon teal & 9 & 0.09 & 0.43 & -0.16 & 0.12 \\
\hline cliff swallow & 9 & 0.47 & 0.04 & 0.37 & 0.47 \\
\hline common yellowthroat & 0 & na & na & na & na \\
\hline double-crested cormorant & 18 & 0.03 & 0.46 & -0.76 & -0.05 \\
\hline eared grebe & 24 & 0.10 & 0.14 & -0.30 & -0.15 \\
\hline Forster's tern & 43 & 0.01 & 0.71 & -0.07 & 0.03 \\
\hline Franklin's gull & 40 & 0.29 & 0.001 & 0.31 & 0.20 \\
\hline gadwall & 10 & 0.09 & 0.41 & -0.01 & 0.12 \\
\hline great blue heron & 18 & 0.23 & 0.04 & -0.31 & 0.12 \\
\hline great egret & 1 & na & na & na & na \\
\hline killdeer & 11 & 0.01 & 0.78 & -0.63 & -0.04 \\
\hline mallard & 16 & 0.11 & 0.22 & -0.63 & -0.18 \\
\hline marsh wren & 18 & 0.48 & 0.001 & 0.12 & 0.21 \\
\hline northern pintail & 3 & 0.13 & 0.76 & -1.04 & -0.32 \\
\hline pied-billed grebe & 24 & 0.01 & 0.75 & -0.38 & -0.03 \\
\hline ring-billed gull & 13 & 0.14 & 0.21 & -0.04 & 0.11 \\
\hline redhead & 12 & 0.15 & 0.21 & 0.18 & 0.12 \\
\hline red-winged blackbird & 10 & 0.10 & 0.38 & -1.19 & -0.22 \\
\hline snowy egret & 5 & 0.04 & 0.75 & 0.01 & 0.08 \\
\hline snowy plover & 10 & 0.05 & 0.53 & -0.08 & 0.08 \\
\hline western grebe & 5 & 0.38 & 0.27 & -0.94 & -0.30 \\
\hline white-faced ibis & 38 & 0.01 & 0.98 & -0.35 & 0.01 \\
\hline Wilson's phalarope & 3 & 0.94 & 0.16 & 0.05 & 0.43 \\
\hline yellow-headed blackbird & 12 & 0.02 & 0.65 & -0.21 & 0.04 \\
\hline
\end{tabular}


Table 3. Percentage of eggs exceeding various toxicity levels of mercury and selenium concentrations for 33 bird species breeding in Great Salt Lake, Utah, 2010-2012.

\begin{tabular}{|c|c|c|c|c|c|c|c|c|c|c|}
\hline \multirow[b]{2}{*}{ Species } & \multicolumn{6}{|c|}{$\begin{array}{l}\text { Eggs exceeding mercury concentration value } \\
\qquad(\mu \mathrm{g} / \mathrm{g} \text { fww) }\end{array}$} & \multicolumn{4}{|c|}{$\begin{array}{l}\text { Eggs exceeding selenium } \\
\text { concentration value } \\
(\mu \mathrm{g} / \mathrm{g} \text { fww })\end{array}$} \\
\hline & $\mathrm{N}$ & $\geq 0.11$ & $\geq 0.25$ & $\geq 0.50$ & $\geq 0.65$ & $\geq 1.00$ & $\mathbf{N}$ & $\geq 0.55$ & $\geq 1.10$ & $\geq 1.41$ \\
\hline American avocet & 336 & $53 \%$ & $11 \%$ & $1 \%$ & $0 \%$ & $0 \%$ & 87 & $93 \%$ & $10 \%$ & $0 \%$ \\
\hline American coot & 145 & $36 \%$ & $12 \%$ & $1 \%$ & $0 \%$ & $0 \%$ & 9 & $44 \%$ & $0 \%$ & $0 \%$ \\
\hline barn swallow & 23 & $52 \%$ & $9 \%$ & $0 \%$ & $0 \%$ & $0 \%$ & 11 & $73 \%$ & $0 \%$ & $0 \%$ \\
\hline $\begin{array}{l}\text { black-crowned night } \\
\text { heron }\end{array}$ & 51 & $73 \%$ & $12 \%$ & $0 \%$ & $0 \%$ & $0 \%$ & 21 & $100 \%$ & $19 \%$ & $5 \%$ \\
\hline brown-headed cowbird & 5 & $0 \%$ & $0 \%$ & $0 \%$ & $0 \%$ & $0 \%$ & 4 & $0 \%$ & $0 \%$ & $0 \%$ \\
\hline black-necked stilt & 211 & $95 \%$ & $48 \%$ & $11 \%$ & $6 \%$ & $2 \%$ & 39 & $100 \%$ & $3 \%$ & $0 \%$ \\
\hline Canada goose & 18 & $0 \%$ & $0 \%$ & $0 \%$ & $0 \%$ & $0 \%$ & 6 & $0 \%$ & $0 \%$ & $0 \%$ \\
\hline California gull & 94 & $33 \%$ & $2 \%$ & $0 \%$ & $0 \%$ & $0 \%$ & 49 & $100 \%$ & $4 \%$ & $0 \%$ \\
\hline Caspian tern & 35 & $100 \%$ & $100 \%$ & $94 \%$ & $86 \%$ & $20 \%$ & 27 & $59 \%$ & $0 \%$ & $0 \%$ \\
\hline cinnamon teal & 44 & $84 \%$ & $5 \%$ & $0 \%$ & $0 \%$ & $0 \%$ & 9 & $100 \%$ & $0 \%$ & $0 \%$ \\
\hline cliff swallow & 96 & $37 \%$ & $0 \%$ & $0 \%$ & $0 \%$ & $0 \%$ & 9 & $44 \%$ & $0 \%$ & $0 \%$ \\
\hline common yellowthroat & 2 & $50 \%$ & $0 \%$ & $0 \%$ & $0 \%$ & $0 \%$ & 0 & na & na & na \\
\hline double-crested cormorant & 65 & $82 \%$ & $23 \%$ & $6 \%$ & $6 \%$ & $0 \%$ & 18 & $33 \%$ & $0 \%$ & $0 \%$ \\
\hline eared grebe & 47 & $34 \%$ & $0 \%$ & $0 \%$ & $0 \%$ & $0 \%$ & 24 & $100 \%$ & $46 \%$ & $4 \%$ \\
\hline Forster's tern & 196 & $100 \%$ & $96 \%$ & $58 \%$ & $35 \%$ & $11 \%$ & 43 & $100 \%$ & $14 \%$ & $0 \%$ \\
\hline Franklin's gull & 114 & $47 \%$ & $1 \%$ & $0 \%$ & $0 \%$ & $0 \%$ & 40 & $100 \%$ & $10 \%$ & $0 \%$ \\
\hline gadwall & 21 & $76 \%$ & $19 \%$ & $0 \%$ & $0 \%$ & $0 \%$ & 10 & $90 \%$ & $0 \%$ & $0 \%$ \\
\hline great blue heron & 61 & $69 \%$ & $8 \%$ & $0 \%$ & $0 \%$ & $0 \%$ & 18 & $50 \%$ & $0 \%$ & $0 \%$ \\
\hline great egret & 2 & $100 \%$ & $50 \%$ & $0 \%$ & $0 \%$ & $0 \%$ & 1 & $100 \%$ & $0 \%$ & $0 \%$ \\
\hline killdeer & 30 & $80 \%$ & $7 \%$ & $0 \%$ & $0 \%$ & $0 \%$ & 11 & $46 \%$ & $0 \%$ & $0 \%$ \\
\hline mallard & 33 & $58 \%$ & $6 \%$ & $0 \%$ & $0 \%$ & $0 \%$ & 16 & $94 \%$ & $0 \%$ & $0 \%$ \\
\hline marsh wren & 274 & $18 \%$ & $1 \%$ & $0 \%$ & $0 \%$ & $0 \%$ & 18 & $89 \%$ & $0 \%$ & $0 \%$ \\
\hline northern pintail & 4 & $100 \%$ & $0 \%$ & $0 \%$ & $0 \%$ & $0 \%$ & 3 & $67 \%$ & $0 \%$ & $0 \%$ \\
\hline pied-billed grebe & 41 & $95 \%$ & $29 \%$ & $2 \%$ & $0 \%$ & $0 \%$ & 24 & $88 \%$ & $0 \%$ & $0 \%$ \\
\hline ring-billed gull & 58 & $10 \%$ & $2 \%$ & $0 \%$ & $0 \%$ & $0 \%$ & 13 & $92 \%$ & $0 \%$ & $0 \%$ \\
\hline redhead & 26 & $50 \%$ & $4 \%$ & $0 \%$ & $0 \%$ & $0 \%$ & 12 & $92 \%$ & $17 \%$ & $0 \%$ \\
\hline red-winged blackbird & 15 & $0 \%$ & $0 \%$ & $0 \%$ & $0 \%$ & $0 \%$ & 10 & $70 \%$ & $0 \%$ & $0 \%$ \\
\hline snowy egret & 29 & $90 \%$ & $40 \%$ & $7 \%$ & $7 \%$ & $0 \%$ & 5 & $100 \%$ & $0 \%$ & $0 \%$ \\
\hline snowy plover & 10 & $100 \%$ & $90 \%$ & $20 \%$ & $20 \%$ & $10 \%$ & 10 & $100 \%$ & $20 \%$ & $0 \%$ \\
\hline western grebe & 11 & $55 \%$ & $9 \%$ & $0 \%$ & $0 \%$ & $0 \%$ & 5 & $100 \%$ & $0 \%$ & $0 \%$ \\
\hline white-faced ibis & 321 & $16 \%$ & $2 \%$ & $0 \%$ & $0 \%$ & $0 \%$ & 38 & $90 \%$ & $0 \%$ & $0 \%$ \\
\hline Wilson's phalarope & 3 & $100 \%$ & $33 \%$ & $0 \%$ & $0 \%$ & $0 \%$ & 3 & $67 \%$ & $0 \%$ & $0 \%$ \\
\hline yellow-headed blackbird & 117 & $2 \%$ & $0 \%$ & $0 \%$ & $0 \%$ & $0 \%$ & 12 & $100 \%$ & $0 \%$ & $0 \%$ \\
\hline
\end{tabular}


Table 4. Total mercury and selenium concentrations ( $\mu \mathrm{g} / \mathrm{g} \mathrm{fww})$ in eggs from 33 bird species breeding in Great Salt Lake, Utah, 2010-2012.

[Values are least squares means \pm standard errors, which account for the global model effects of species, region, and year]

\begin{tabular}{|c|c|c|c|c|c|c|}
\hline \multirow{2}{*}{ Species } & \multicolumn{3}{|c|}{ Egg mercury concentration } & \multicolumn{3}{|c|}{ Egg selenium concentration } \\
\hline & $\mathbf{N}$ & Mean & SE & $\mathbf{N}$ & Mean & SE \\
\hline American avocet & 336 & 0.12 & 0.01 & 87 & 0.82 & 0.02 \\
\hline American coot & 145 & 0.10 & 0.01 & 9 & 0.53 & 0.04 \\
\hline barn swallow & 23 & 0.11 & 0.01 & 11 & 0.63 & 0.04 \\
\hline black-crowned night heron & 51 & 0.17 & 0.02 & 21 & 0.98 & 0.05 \\
\hline brown-headed cowbird & 5 & 0.05 & 0.01 & 4 & 0.49 & 0.05 \\
\hline black-necked stilt & 211 & 0.30 & 0.02 & 39 & 0.83 & 0.03 \\
\hline Canada goose & 18 & 0.01 & 0.00 & 6 & 0.30 & 0.02 \\
\hline California gull & 94 & 0.08 & 0.01 & 49 & 0.80 & 0.03 \\
\hline Caspian tern & 35 & 0.87 & 0.09 & 27 & 0.63 & 0.03 \\
\hline cinnamon teal & 44 & 0.15 & 0.02 & 9 & 0.72 & 0.05 \\
\hline cliff swallow & 96 & 0.10 & 0.01 & 9 & 0.56 & 0.04 \\
\hline common yellowthroat & 2 & 0.09 & 0.03 & 0 & na & na \\
\hline double-crested cormorant & 65 & 0.18 & 0.02 & 18 & 0.53 & 0.03 \\
\hline eared grebe & 47 & 0.10 & 0.01 & 24 & 1.11 & 0.05 \\
\hline Forster's tern & 196 & 0.64 & 0.05 & 43 & 0.99 & 0.04 \\
\hline Franklin's gull & 114 & 0.11 & 0.01 & 40 & 0.95 & 0.04 \\
\hline gadwall & 21 & 0.16 & 0.02 & 10 & 0.85 & 0.06 \\
\hline great blue heron & 61 & 0.14 & 0.01 & 18 & 0.63 & 0.03 \\
\hline great egret & 2 & 0.30 & 0.11 & 1 & 0.85 & 0.16 \\
\hline killdeer & 30 & 0.15 & 0.02 & 11 & 0.61 & 0.04 \\
\hline mallard & 33 & 0.13 & 0.01 & 16 & 0.80 & 0.04 \\
\hline marsh wren & 274 & 0.10 & 0.01 & 18 & 0.78 & 0.04 \\
\hline northern pintail & 4 & 0.18 & 0.05 & 3 & 0.71 & 0.08 \\
\hline pied-billed grebe & 41 & 0.22 & 0.02 & 24 & 0.78 & 0.04 \\
\hline ring-billed gull & 58 & 0.07 & 0.01 & 13 & 0.75 & 0.04 \\
\hline redhead & 26 & 0.10 & 0.01 & 12 & 0.93 & 0.06 \\
\hline red-winged blackbird & 15 & 0.07 & 0.01 & 10 & 0.63 & 0.04 \\
\hline snowy egret & 29 & 0.27 & 0.03 & 5 & 0.89 & 0.08 \\
\hline snowy plover & 10 & 0.44 & 0.08 & 10 & 0.96 & 0.06 \\
\hline western grebe & 11 & 0.14 & 0.02 & 5 & 0.87 & 0.08 \\
\hline white-faced ibis & 321 & 0.08 & 0.01 & 38 & 0.76 & 0.03 \\
\hline Wilson's phalarope & 3 & 0.23 & 0.07 & 3 & 0.66 & 0.07 \\
\hline yellow-headed blackbird & 117 & 0.04 & 0.00 & 12 & 0.78 & 0.05 \\
\hline
\end{tabular}


Table 5. Factors influencing egg mercury concentrations in 33 bird species breeding in Great Salt Lake, Utah, 2010-2012.

[Table values report p-values from Analysis of Covariance for each variable; values highlighted in gray were significant. "na" indicates that that variable was removed from the model because there was no more than one category in that factor. Species with an asterisk had models with site as the only variable because of singularities in the model structure]

\begin{tabular}{|c|c|c|c|c|c|}
\hline Species & $\mathbf{N}$ & Site[region] & Region & Year & Date \\
\hline American avocet & 336 & 0.0001 & 0.001 & 0.0001 & 0.68 \\
\hline American coot & 145 & 0.0001 & 0.01 & 0.29 & 0.17 \\
\hline barn swallow & 23 & 0.06 & 0.0001 & 0.08 & 0.85 \\
\hline black-crowned night heron* & 51 & 0.42 & na & na & na \\
\hline brown-headed cowbird & 4 & na & na & na & 0.92 \\
\hline black-necked stilt & 211 & 0.50 & 0.03 & 0.02 & 0.002 \\
\hline Canada goose & 18 & 0.04 & na & 0.47 & 0.28 \\
\hline California gull & 94 & 0.76 & 0.001 & 0.0001 & 0.06 \\
\hline Caspian tern & 35 & na & na & 0.33 & 0.42 \\
\hline cinnamon teal & 44 & 0.62 & 0.19 & 0.85 & 0.25 \\
\hline cliff swallow & 96 & 0.0001 & na & 0.48 & 0.40 \\
\hline common yellowthroat & 2 & na & na & na & na \\
\hline double-crested cormorant & 65 & na & 0.55 & 0.29 & 0.71 \\
\hline eared grebe & 47 & 0.73 & na & 0.92 & 0.99 \\
\hline Forster's tern & 196 & 0.61 & na & 0.18 & 0.06 \\
\hline Franklin's gull & 114 & 0.01 & na & 0.04 & 0.05 \\
\hline gadwall* & 21 & 0.12 & na & na & na \\
\hline great blue heron & 61 & 0.15 & 0.84 & 0.73 & 0.23 \\
\hline great egret & 2 & na & na & na & na \\
\hline killdeer & 30 & 0.70 & 0.24 & 0.62 & 0.98 \\
\hline mallard & 33 & 0.44 & 0.29 & 0.30 & 0.81 \\
\hline marsh wren & 274 & 0.0001 & 0.0001 & 0.001 & 0.0001 \\
\hline northern pintail & 4 & na & na & na & na \\
\hline pied-billed grebe & 41 & 0.30 & na & 0.99 & 0.02 \\
\hline ring-billed gull & 58 & 0.90 & na & 0.76 & 0.99 \\
\hline redhead & 26 & 0.07 & na & 0.99 & 0.78 \\
\hline red-winged blackbird & 15 & na & na & na & 0.46 \\
\hline snowy egret* & 29 & 0.33 & na & na & na \\
\hline snowy plover & 10 & 0.44 & na & 0.91 & 0.91 \\
\hline western grebe* & 11 & 0.0001 & na & na & na \\
\hline white-faced ibis & 321 & 0.28 & na & 0.003 & 0.0001 \\
\hline Wilson's phalarope & 3 & na & na & na & na \\
\hline yellow-headed blackbird & 117 & 0.0001 & 0.0001 & 0.04 & 0.37 \\
\hline
\end{tabular}


Table 6. Factors influencing egg selenium concentrations in 33 bird species breeding in Great Salt Lake, Utah, 2010-2012.

[Table values report p-values from Analysis of Covariance for each variable; values highlighted in gray were significant. "na" indicates that that variable was removed from the model because there was no more than one category in that factor. Species with an asterisk had models with site as the only variable because of singularities in the model structure]

\begin{tabular}{|c|c|c|c|}
\hline Species & $\mathrm{N}$ & Site & Year \\
\hline American avocet & 87 & 0.0001 & 0.63 \\
\hline American coot* & 9 & 0.51 & na \\
\hline barn swallow & 11 & 0.19 & 0.26 \\
\hline $\begin{array}{l}\text { black-crowned } \\
\text { night heron* }\end{array}$ & 21 & 0.67 & na \\
\hline $\begin{array}{l}\text { brown-headed } \\
\text { cowbird }\end{array}$ & 4 & na & na \\
\hline black-necked stilt* & 39 & 0.05 & na \\
\hline Canada goose & 6 & na & na \\
\hline California gull & 49 & 0.25 & 0.32 \\
\hline Caspian tern & 27 & na & 0.0001 \\
\hline cinnamon teal & 9 & 0.33 & 0.71 \\
\hline cliff swallow & 9 & 0.30 & 0.25 \\
\hline $\begin{array}{l}\text { common } \\
\text { yellowthroat }\end{array}$ & 0 & na & na \\
\hline $\begin{array}{l}\text { double-crested } \\
\text { cormorant }\end{array}$ & 18 & 0.10 & 0.18 \\
\hline eared grebe & 24 & na & 0.72 \\
\hline Forster's tern & 43 & 0.01 & 0.89 \\
\hline Franklin's gull & 40 & 0.03 & 0.02 \\
\hline gadwall* & 10 & 0.18 & na \\
\hline great blue heron & 18 & 0.56 & 0.06 \\
\hline great egret & 1 & na & na \\
\hline killdeer & 11 & 0.43 & 0.83 \\
\hline mallard & 16 & 0.44 & 0.03 \\
\hline marsh wren & 18 & 0.01 & 0.63 \\
\hline northern pintail & 3 & na & na \\
\hline pied-billed grebe & 24 & 0.23 & 0.002 \\
\hline ring-billed gull & 13 & 0.82 & 0.23 \\
\hline redhead & 12 & 0.04 & 0.01 \\
\hline $\begin{array}{l}\text { red-winged } \\
\text { blackbird }\end{array}$ & 10 & na & na \\
\hline snowy egret & 5 & na & na \\
\hline snowy plover & 10 & 0.67 & 0.01 \\
\hline western grebe & 5 & na & na \\
\hline white-faced ibis & 38 & 0.08 & 0.10 \\
\hline Wilson's phalarope & 3 & na & na \\
\hline $\begin{array}{l}\text { yellow-headed } \\
\text { blackbird }\end{array}$ & 12 & 0.31 & 0.31 \\
\hline
\end{tabular}


Table 7. Influence of total mercury concentrations on egg volume in 33 bird species breeding in Great Salt Lake, Utah. 2010-2012.

[Table values report p-values from Analysis of Covariance for each variable; values highlighted in gray were significant. "na" indicates that that variable was removed from the model because there was no more than one category in that factor. Species with an asterisk indicate models where we removed year from the model because of singularities in the model structure]

\begin{tabular}{|c|c|c|c|c|c|}
\hline Species & $\mathbf{N}$ & In Egg THg & Site & Year & Date \\
\hline American avocet & 336 & 0.98 & 0.60 & 0.13 & 0.001 \\
\hline American coot & 145 & 0.73 & 0.40 & 0.38 & 0.72 \\
\hline barn swallow & 23 & 0.65 & 0.72 & 0.27 & 0.49 \\
\hline black-crowned night heron* & 51 & 0.002 & 0.37 & na & 0.68 \\
\hline brown-headed cowbird & 4 & 0.16 & na & na & 0.19 \\
\hline black-necked stilt & 211 & 0.0002 & 0.02 & 0.09 & 0.003 \\
\hline Canada goose & 18 & 0.58 & 0.71 & 0.62 & 0.53 \\
\hline California gull & 94 & 0.57 & 0.54 & 0.84 & 0.001 \\
\hline Caspian tern & 35 & 0.46 & na & 0.99 & 0.05 \\
\hline cinnamon teal & 44 & 0.52 & 0.70 & 0.14 & 0.02 \\
\hline cliff swallow & 96 & 0.63 & 0.02 & 0.001 & 0.26 \\
\hline common yellowthroat & 2 & na & na & na & na \\
\hline double-crested cormorant & 65 & 0.40 & 0.55 & 0.79 & 0.76 \\
\hline eared grebe & 47 & 0.09 & 0.13 & 0.13 & 0.24 \\
\hline Forster's tern & 196 & 0.04 & 0.61 & 0.004 & 0.55 \\
\hline Franklin's gull & 114 & 0.20 & 0.80 & 0.43 & 0.69 \\
\hline gadwall* & 21 & 0.02 & 0.03 & na & 0.71 \\
\hline great blue heron & 61 & 0.06 & 0.19 & 0.17 & 0.57 \\
\hline great egret & 2 & na & na & na & na \\
\hline killdeer & 30 & 0.13 & 0.54 & 0.39 & 0.14 \\
\hline mallard & 33 & 0.24 & 0.81 & 0.31 & 0.69 \\
\hline marsh wren & 274 & 0.72 & 0.49 & 0.14 & 0.05 \\
\hline northern pintail & 4 & na & na & na & na \\
\hline pied-billed grebe & 41 & 0.33 & 0.73 & 0.36 & 0.20 \\
\hline ring-billed gull & 58 & 0.76 & 0.31 & 0.11 & 0.61 \\
\hline redhead & 26 & 0.21 & 0.28 & 0.01 & 0.51 \\
\hline red-winged blackbird & 15 & 0.28 & na & na & 0.99 \\
\hline snowy egret* & 29 & 0.10 & 0.93 & na & 0.83 \\
\hline snowy plover & 10 & 0.003 & 0.3 & 0.06 & 0.05 \\
\hline western grebe* & 11 & 0.99 & 0.73 & na & 0.92 \\
\hline white-faced ibis & 321 & 0.30 & 0.63 & 0.13 & 0.05 \\
\hline Wilson's phalarope & 3 & na & na & na & na \\
\hline yellow-headed blackbird & 117 & 0.40 & 0.79 & 0.22 & 0.18 \\
\hline
\end{tabular}


Table 8. Influence of selenium concentrations on egg volume in 33 bird species breeding in Great Salt Lake, Utah, 2010-2012.

[Table values report p-values from Analysis of Covariance for each variable; values highlighted in gray were significant. "na" indicates that that variable was removed from the model because there was no more than one category in that factor. Species with an asterisk indicate models where we removed year from the model, species with two asterisks indicate models where we removed year and date from the model, and species with three asterisks indicate models where we removed year, date, and site from the model because of singularities in the model structure]

\begin{tabular}{|c|c|c|c|c|c|}
\hline Species & $\mathbf{N}$ & In Egg Se & Site & Year & Date \\
\hline American avocet & 87 & 0.84 & 0.47 & 0.78 & 0.41 \\
\hline American $\operatorname{coot}^{* * *}$ & 9 & 0.02 & na & na & na \\
\hline barn swallow & 11 & 0.94 & 0.86 & 0.21 & 0.29 \\
\hline black-crowned night heron* & 21 & 0.21 & 0.14 & na & 0.25 \\
\hline brown-headed cowbird & 4 & na & na & na & na \\
\hline black-necked stilt* & 39 & 0.79 & 0.02 & na & 0.004 \\
\hline Canada goose & 3 & na & na & na & na \\
\hline California gull & 49 & 0.11 & 0.03 & 0.24 & 0.88 \\
\hline Caspian tern & 27 & 0.53 & na & 0.87 & 0.22 \\
\hline cinnamon teal* & 9 & 0.55 & 0.68 & na & 0.94 \\
\hline cliff swallow* & 9 & 0.99 & 0.94 & na & 0.99 \\
\hline common yellowthroat & 0 & na & na & na & na \\
\hline double-crested cormorant & 18 & 0.34 & 0.36 & 0.06 & 0.07 \\
\hline eared grebe & 24 & 0.06 & na & 0.35 & 0.20 \\
\hline Forster's tern & 43 & 0.0003 & 0.58 & 0.002 & 0.10 \\
\hline Franklin's gull & 40 & 0.98 & 0.87 & 0.23 & 0.20 \\
\hline gadwall*** & 10 & 0.14 & na & na & na \\
\hline great blue heron & 18 & 0.66 & 0.02 & 0.21 & 0.004 \\
\hline great egret & 1 & na & na & na & na \\
\hline killdeer** & 11 & 0.77 & 0.66 & na & na \\
\hline mallard & 16 & 0.98 & 0.72 & 0.98 & 0.91 \\
\hline marsh wren & 18 & 0.10 & 0.45 & 0.25 & 0.73 \\
\hline northern pintail & 3 & na & na & na & na \\
\hline pied-billed grebe & 24 & 0.85 & 0.87 & 0.43 & 0.93 \\
\hline ring-billed gull & 13 & 0.62 & 0.8 & 0.34 & 0.63 \\
\hline redhead & 12 & 0.40 & 0.6 & 0.11 & 0.23 \\
\hline red-winged blackbird & 10 & 0.42 & na & na & 0.88 \\
\hline snowy egret & 5 & na & na & na & na \\
\hline snowy plover & 10 & 0.27 & 0.98 & 0.2 & 0.78 \\
\hline western grebe & 5 & na & na & na & na \\
\hline white-faced ibis & 38 & 0.65 & 0.03 & 0.6 & 0.03 \\
\hline Wilson's phalarope & 3 & na & na & na & na \\
\hline yellow-headed blackbird & 12 & 0.57 & 0.16 & 0.79 & 0.15 \\
\hline
\end{tabular}


Table 9. Summary of fates for micro-sampled, sham, and control eggs within nests that were micro-sampled for albumen mercury concentrations for American avocets, black-necked stilts, and Forster's terns breeding in Great Salt Lake, Utah, 2012.

[Within each nest, one egg was designated for micro-sampling, one egg was designated a sham egg (micro-sample whole drilled in egg but no albumen was removed), and one egg was designated as a control egg (egg was handled, but not micro-sampled or drilled)]

\begin{tabular}{llccrc}
\hline \multicolumn{1}{c}{ Species } & Egg fate & $\begin{array}{c}\text { Mean THg } \\
\text { concentration in } \\
\text { micro-sampled egg } \\
\text { albumen }\end{array}$ & $\begin{array}{c}\text { Micro-sampled } \\
\text { eggs }\end{array}$ & Sham eggs & Control eggs \\
\hline American avocet & Hatched & $0.10 \pm 0.02$ & 10 & 10 & 9 \\
& Failed to hatch & $0.08 \pm 0.02$ & 14 & 14 & 15 \\
Black-necked stilt & Hatched & $0.24 \pm 0.12$ & 8 & 7 & 7 \\
& Failed to hatch & $0.31 \pm 0.05$ & 17 & 18 & 18 \\
& Hatched & $0.88 \pm 0.25$ & 11 & 11 & 4 \\
\hline
\end{tabular}

Table 10. Summary of fates for micro-sampled and not micro-sampled nests for American avocets, black-necked stilts, and Forster's terns breeding in Great Salt Lake, Utah in 2012.

\begin{tabular}{llll}
\hline \multicolumn{1}{c}{ Species } & \multicolumn{1}{c}{ Nest type } & \multicolumn{1}{c}{ Micro-sampled } & \multicolumn{1}{c}{ Not micro-sampled } \\
\hline American avocet & N (nests) & 24 & 224 \\
& All eggs hatched & $6(25 \%)$ & $47(21 \%)$ \\
& 1 or more eggs failed to hatch & $8(33 \%)$ & $91(41 \%)$ \\
& Nest was abandoned & $2(8 \%)$ & $44(20 \%)$ \\
& Nest was depredated or destroyed & $8(33 \%)$ & $42(19 \%)$ \\
Black-necked stilt & & 201 \\
& N (nests) & 25 & $5(2 \%)$ \\
& All eggs hatched & $5(20 \%)$ & $103(51 \%)$ \\
& 1 or more eggs failed to hatch & $6(24 \%)$ & $25(12 \%)$ \\
& Nest was abandoned & $1(4 \%)$ & $67(33 \%)$ \\
& Nest was depredated or destroyed & $13(52 \%)$ & \\
& & & 567 \\
Forster's tern & N (nests) & 20 & $125(22 \%)$ \\
& All eggs hatched & $7(35 \%)$ & $153(27 \%)$ \\
& 1 or more eggs failed to hatch & $7(35 \%)$ & $108(19 \%)$ \\
& Nest was abandoned & $4(20 \%)$ & $179(32 \%)$ \\
\hline
\end{tabular}


Table 11. Summary of fates within nests that were micro-sampled for albumen mercury concentrations for American avocets, black-necked stilts, and Forster's terns breeding in Great Salt Lake, Utah, 2012.

[Within each nest, one egg was designated for micro-sampling, one egg was designated a sham egg (micro-sample whole drilled in egg but no albumen was removed), and one egg was designated as a control egg (egg was handled, but not micro-sampled or drilled)]

\begin{tabular}{llll}
\hline \multicolumn{1}{c}{ Species } & \multicolumn{1}{c}{$\begin{array}{c}\text { Egg fate } \\
\text { (Micro-sampled:control) }\end{array}$} & $\begin{array}{c}\text { Number of } \\
\text { nests }\end{array}$ & $\begin{array}{c}\text { Mean THg concentration in } \\
\text { micro-sampled egg } \\
\text { albumen }\end{array}$ \\
\hline American avocet & Hatched:Hatched & 9 & $0.09 \pm 0.02$ \\
& Hatched:Failed & 1 & $0.125 \pm$ na \\
& Failed:Hatched & 0 & na \\
Black-necked stilt & Failed:Failed & 14 & $0.08 \pm 0.02$ \\
& Hatched:Hatched & 5 & $0.32 \pm 0.12$ \\
& Hatched:Failed & 3 & $0.16 \pm 0.13$ \\
Forster's tern & Failed:Hatched & 2 & $0.29 \pm 0.13$ \\
& Failed:Failed & 15 & $0.32 \pm 0.06$ \\
& Hatched:Hatched & 3 & $0.70 \pm 0.46$ \\
& Hatched:Failed & 8 & $0.95 \pm 0.24$ \\
& Failed:Hatched & 1 & $0.92 \pm$ na \\
& Failed:Failed & 8 & $0.52 \pm 0.22$ \\
\hline
\end{tabular}


This page left intentionally blank 


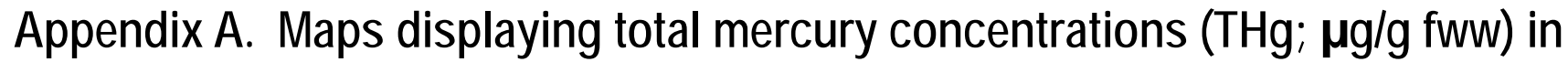 eggs of 33 species of birds breeding in Great Salt Lake, Utah, 2010-2012. Species are displayed alphabetically.}




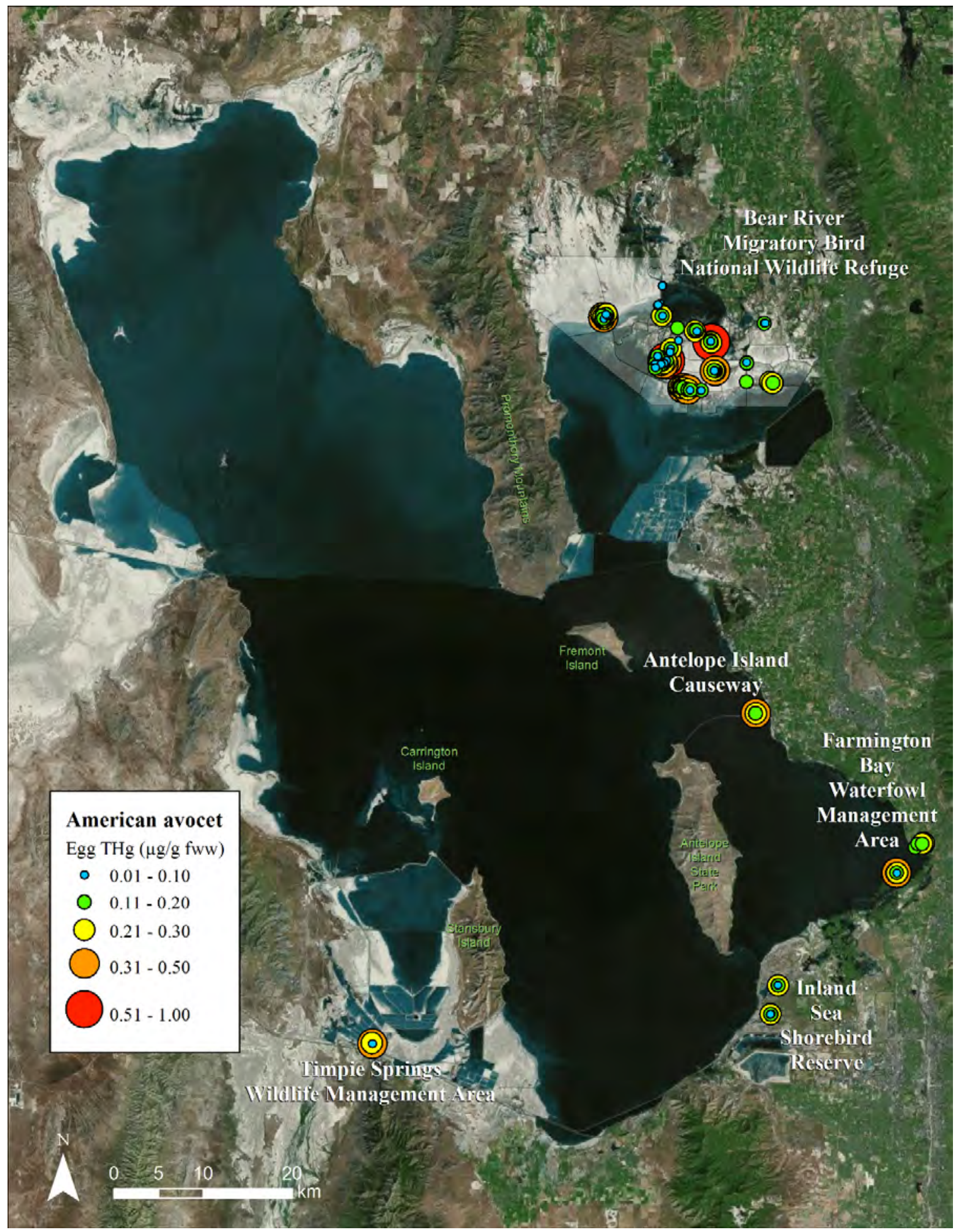

Figure A-1. Total mercury concentrations (THg; $\mu \mathrm{g} / \mathrm{g}$ fww) in eggs of American avocets breeding in Great Salt Lake, Utah, 2010-2012. 


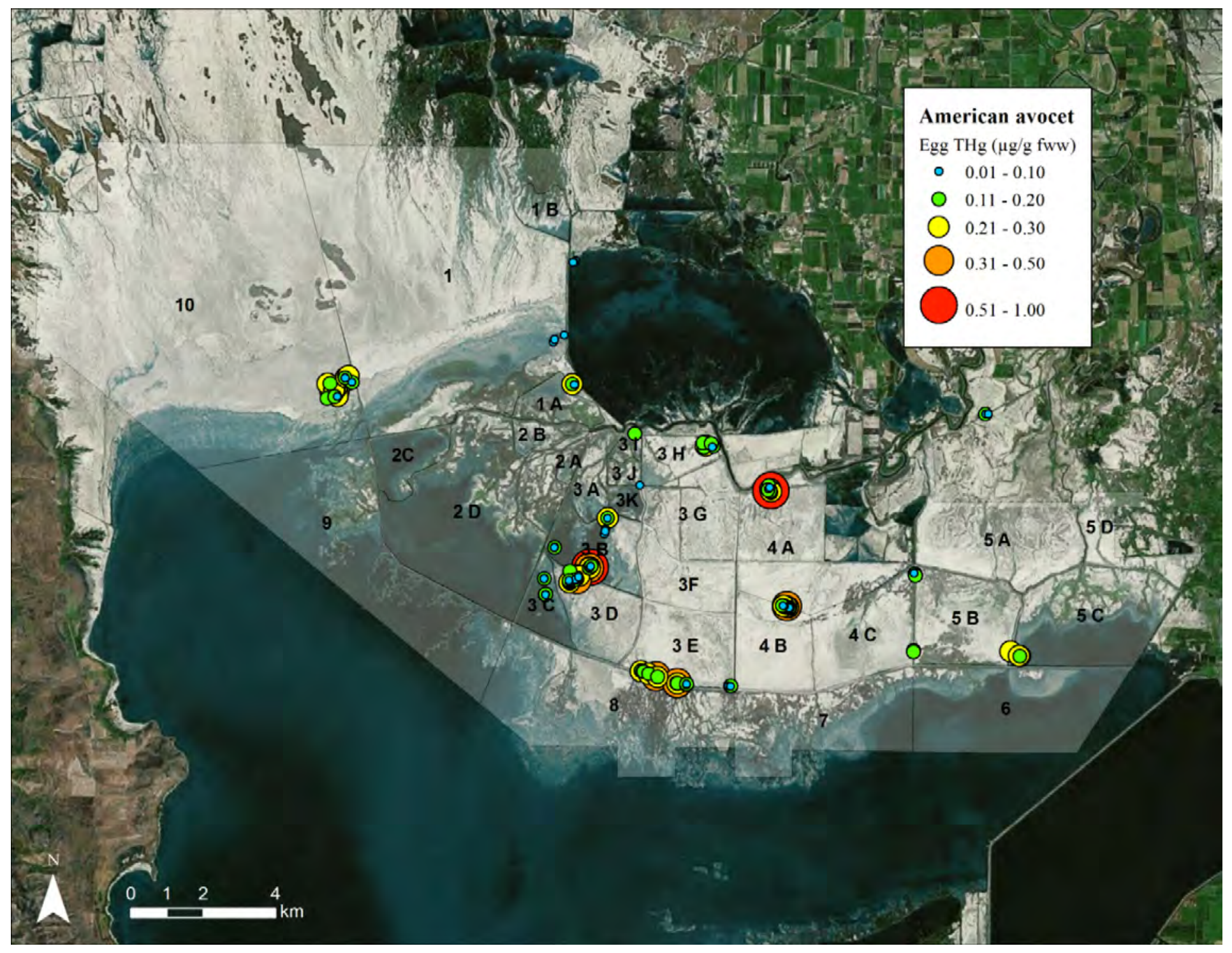

Figure A-2. Total mercury concentrations (THg; $\mu \mathrm{g} / \mathrm{g} \mathrm{fww}$ ) in eggs of American avocets breeding at Bear River Migratory Bird Refuge in Great Salt Lake, Utah, 2010-2012. 


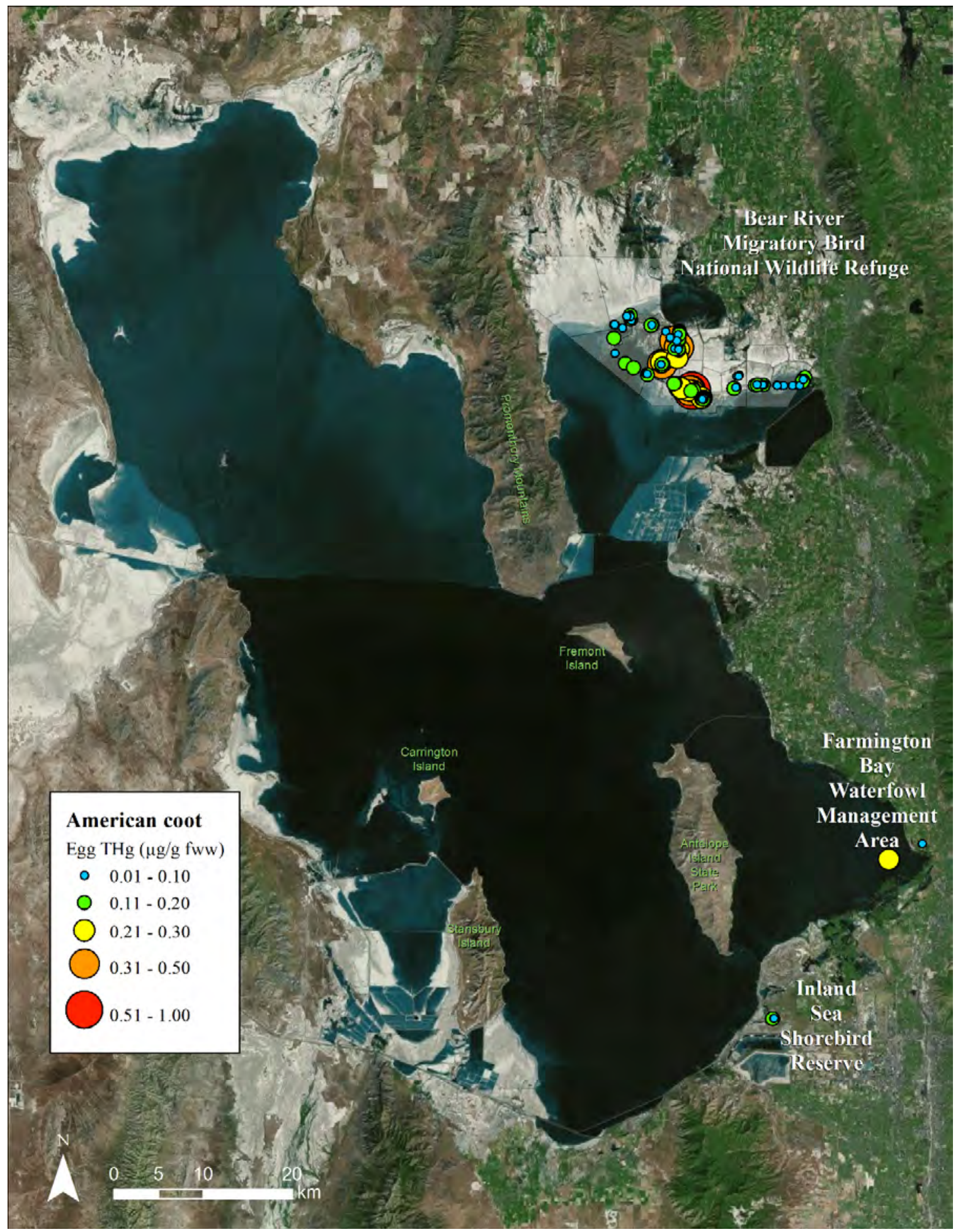

Figure A-3. Total mercury concentrations (THg; $\mu \mathrm{g} / \mathrm{g} \mathrm{fww}$ ) in eggs of American coots breeding in Great Salt Lake, Utah, 2010-2012. 


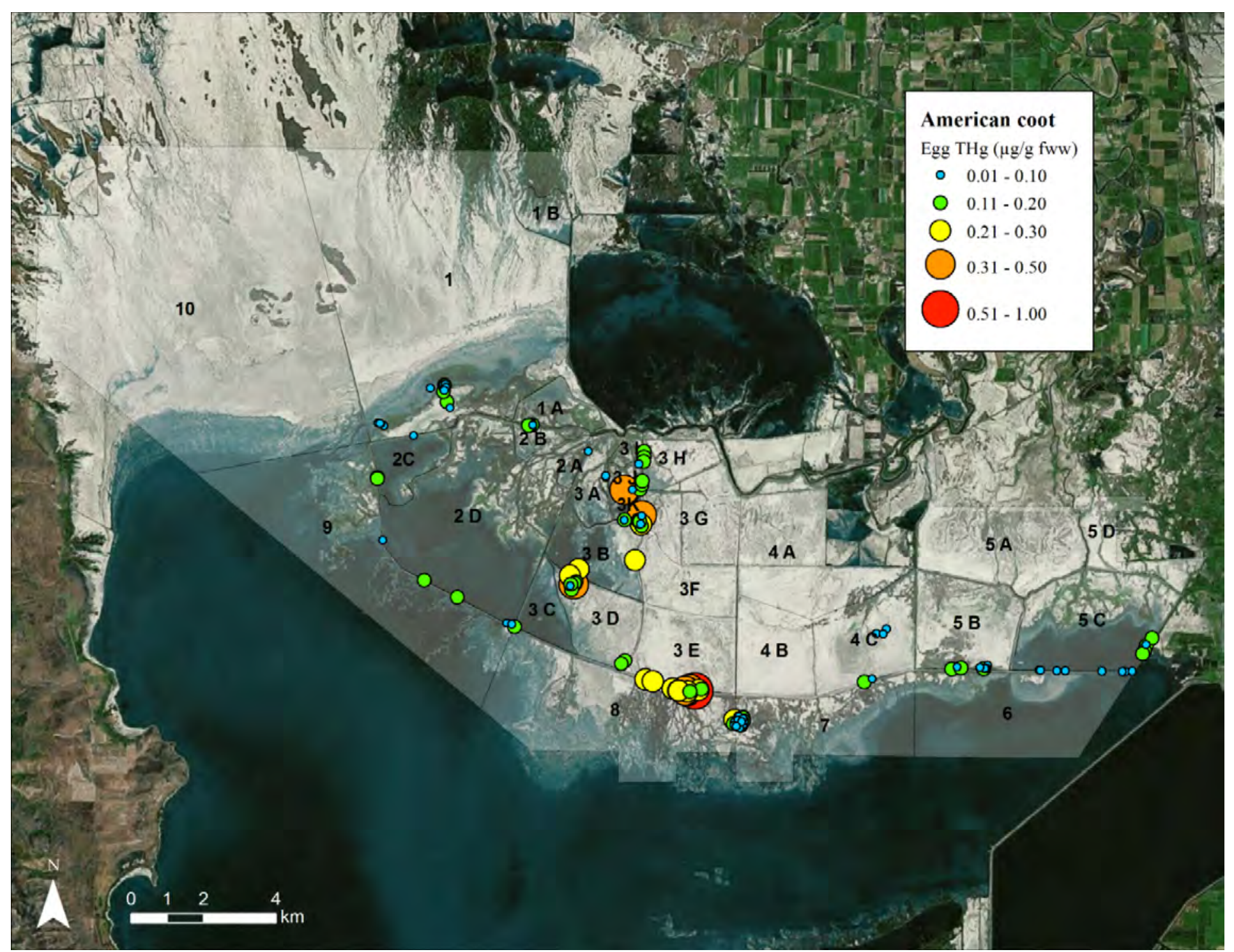

Figure A-4. Total mercury concentrations ( $\mathrm{THg} ; \mu \mathrm{g} / \mathrm{g} \mathrm{fww}$ ) in eggs of American coots breeding at Bear River Migratory Bird Refuge in Great Salt Lake, Utah, 2010-2012. 


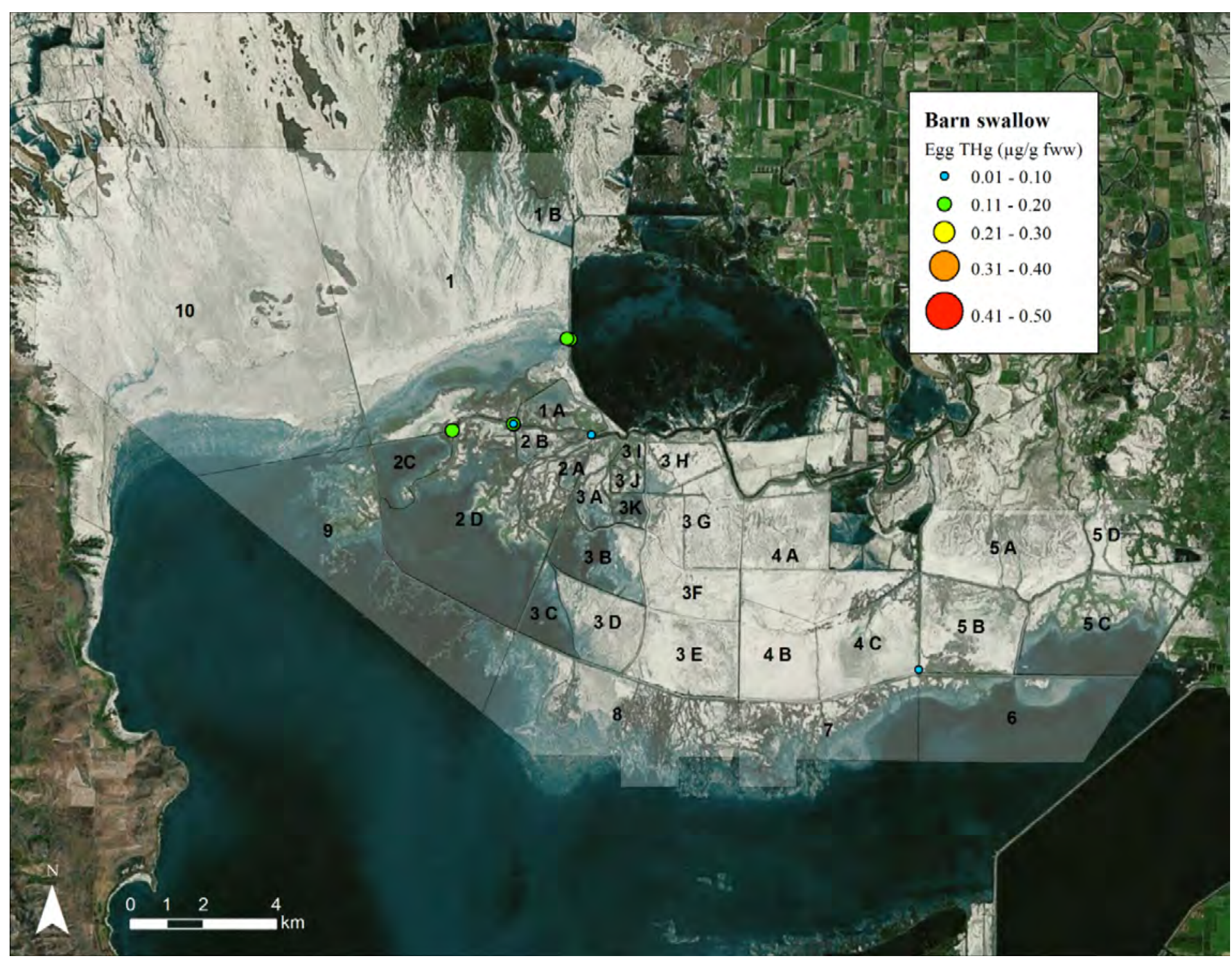

Figure A-5. Total mercury concentrations (THg; $\mu \mathrm{g} / \mathrm{g} \mathrm{fww}$ ) in eggs of barn swallows breeding at Bear River Migratory Bird Refuge in Great Salt Lake, Utah, 2010-2012. 


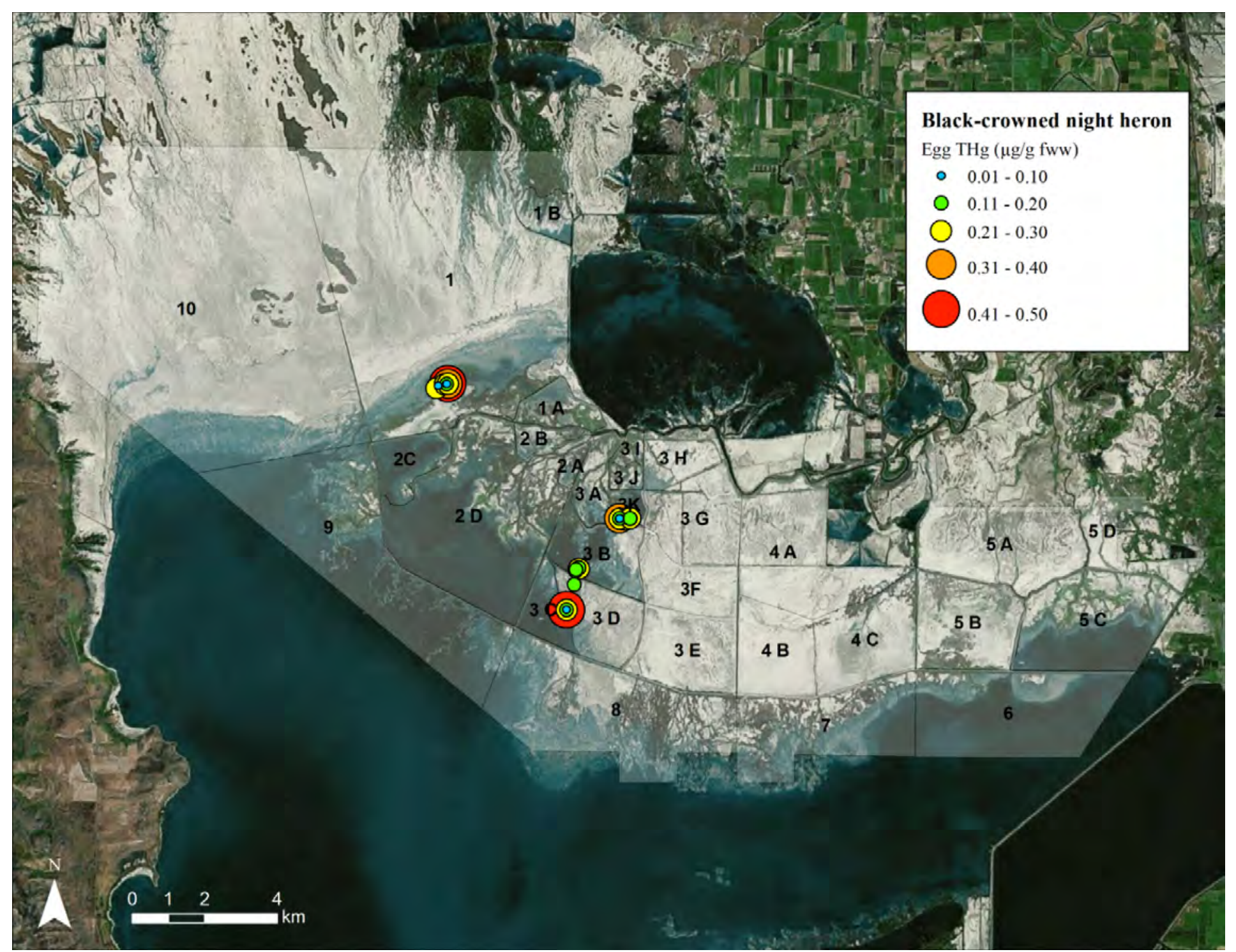

Figure A-6. Total mercury concentrations ( $\mathrm{THg} ; \mu \mathrm{g} / \mathrm{g} \mathrm{fww}$ ) in eggs of black-crowned night herons breeding at Bear River Migratory Bird Refuge in Great Salt Lake, Utah, 2010-2012. 


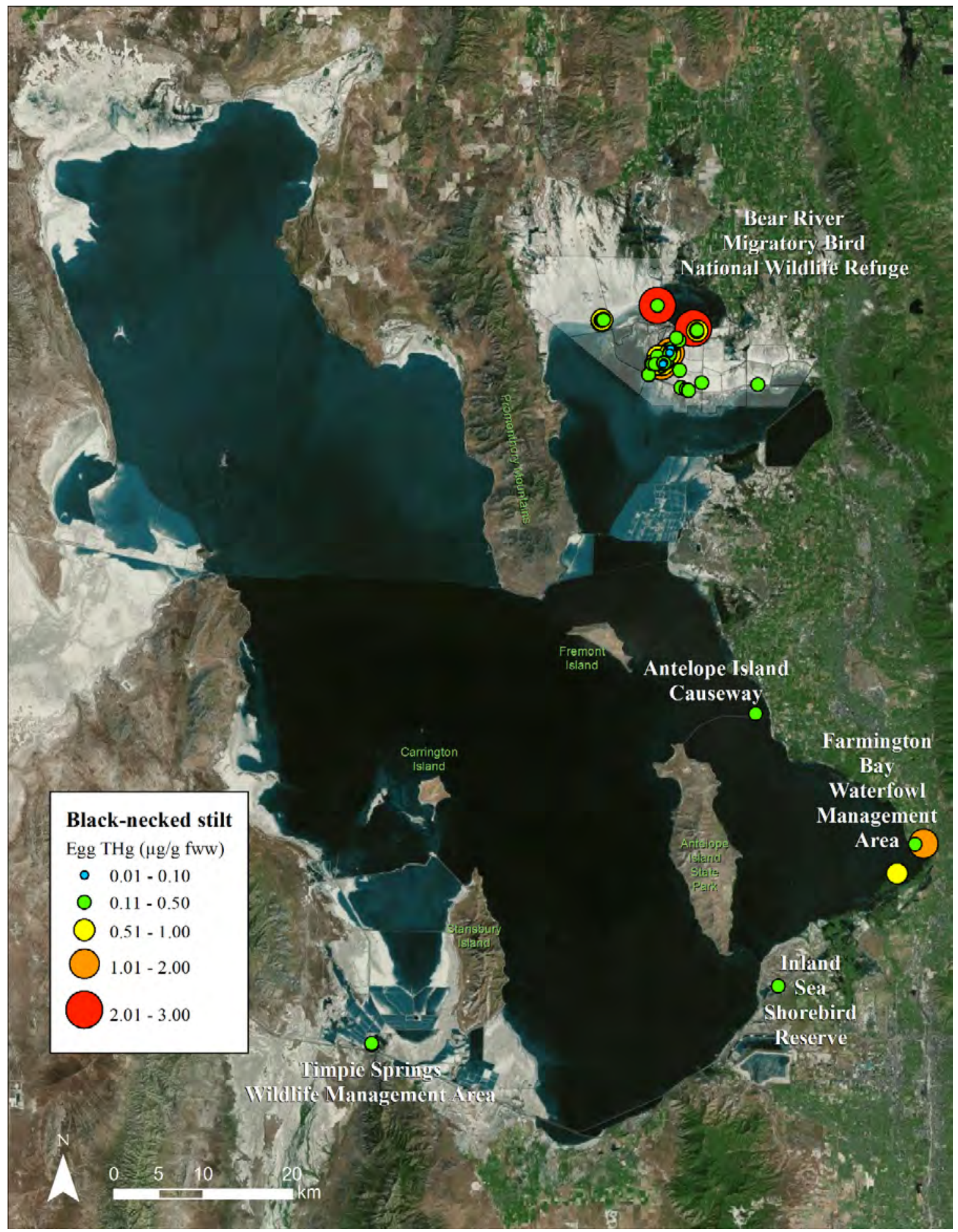

Figure A-7. Total mercury concentrations (THg; $\mu \mathrm{g} / \mathrm{g} \mathrm{fww}$ ) in eggs of black-necked stilts breeding in Great Salt Lake, Utah, 2010-2012. 


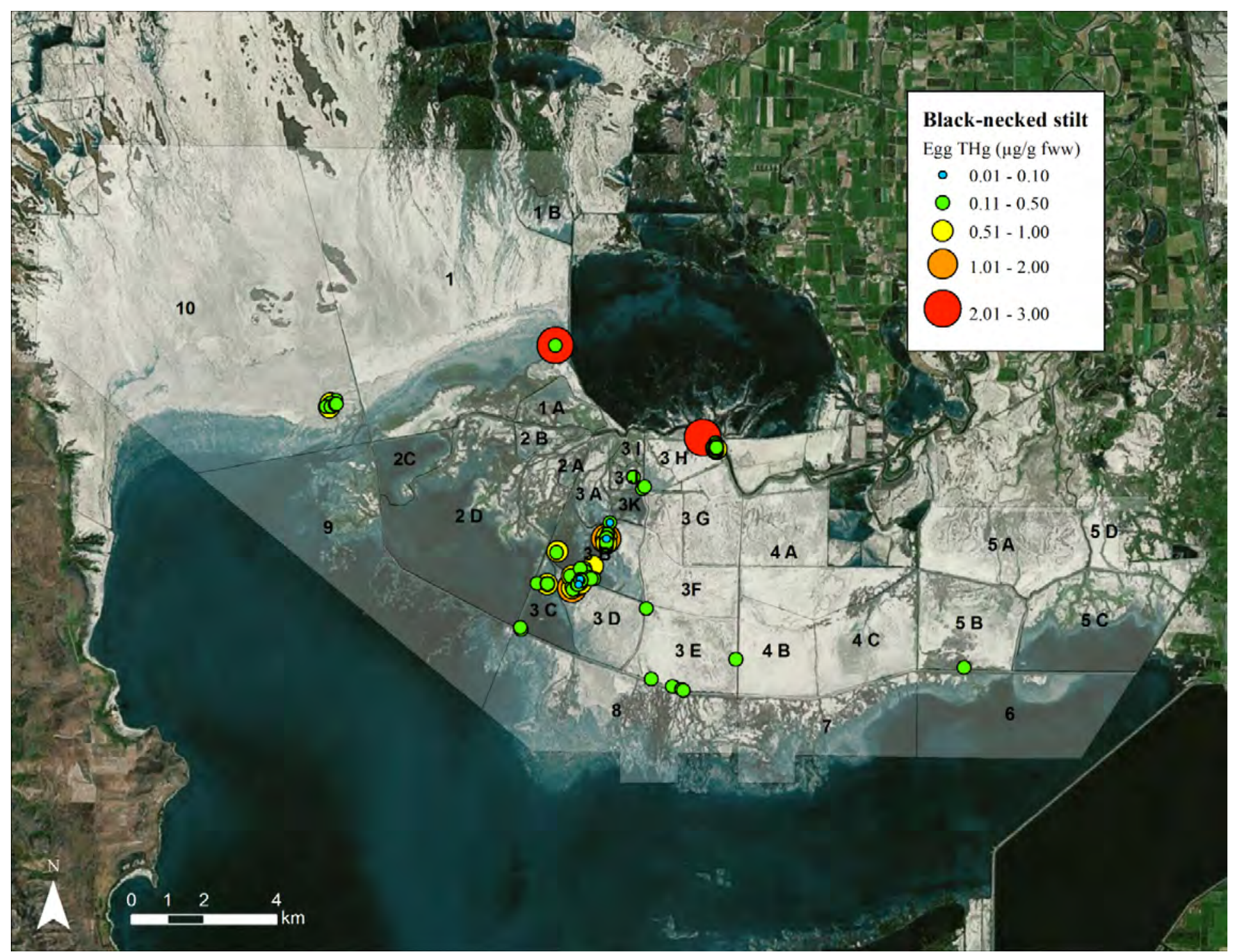

Figure A-8. Total mercury concentrations ( $\mathrm{THg} ; \mu \mathrm{g} / \mathrm{g} \mathrm{fww}$ ) in eggs of black-necked stilts breeding at Bear River Migratory Bird Refuge in Great Salt Lake, Utah, 2010-2012. 


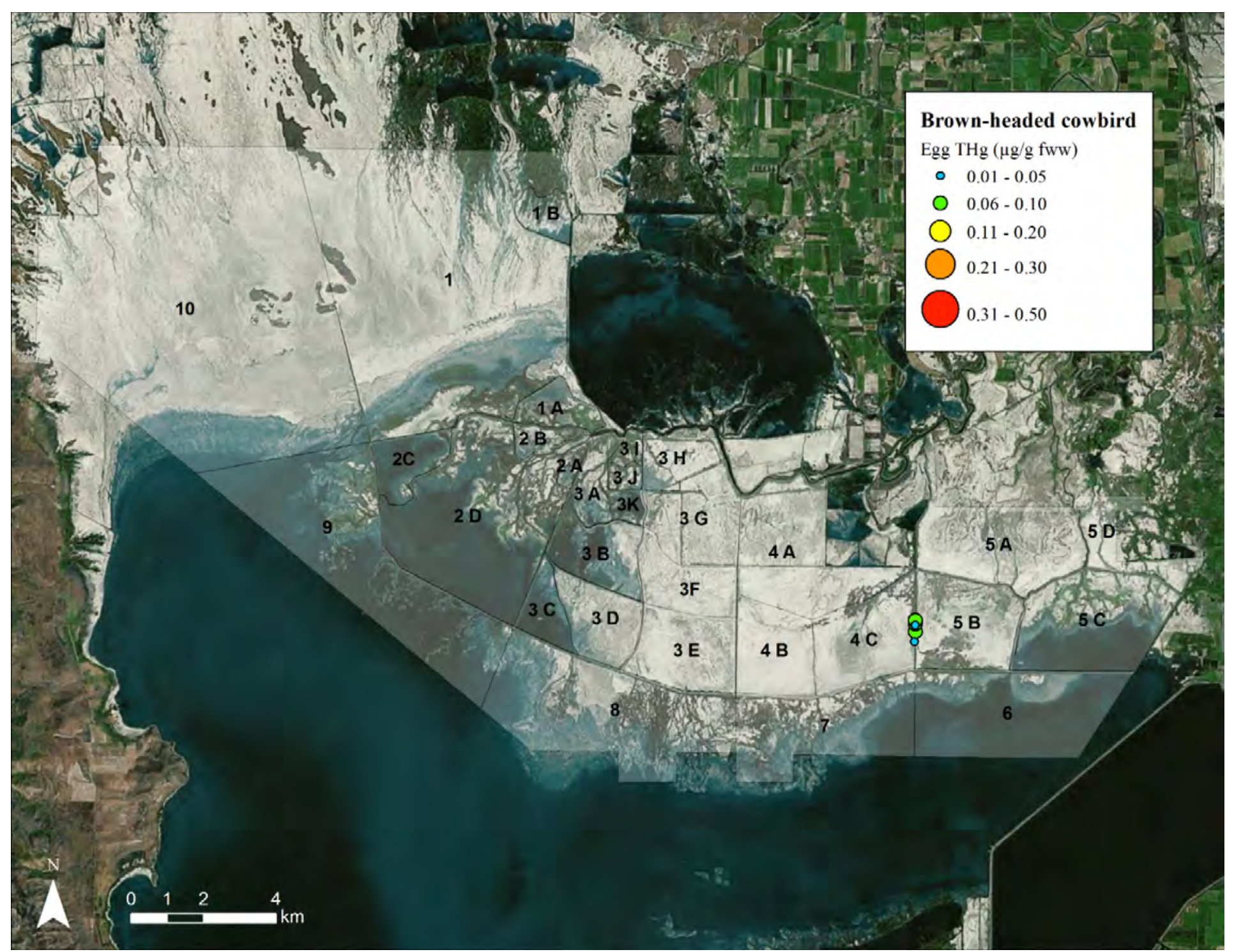

Figure A-9. Total mercury concentrations (THg; $\mu \mathrm{g} / \mathrm{g} \mathrm{fww)}$ ) in eggs of brown-headed cowbirds breeding at Bear River Migratory Bird Refuge in Great Salt Lake, Utah, 2010-2012. 


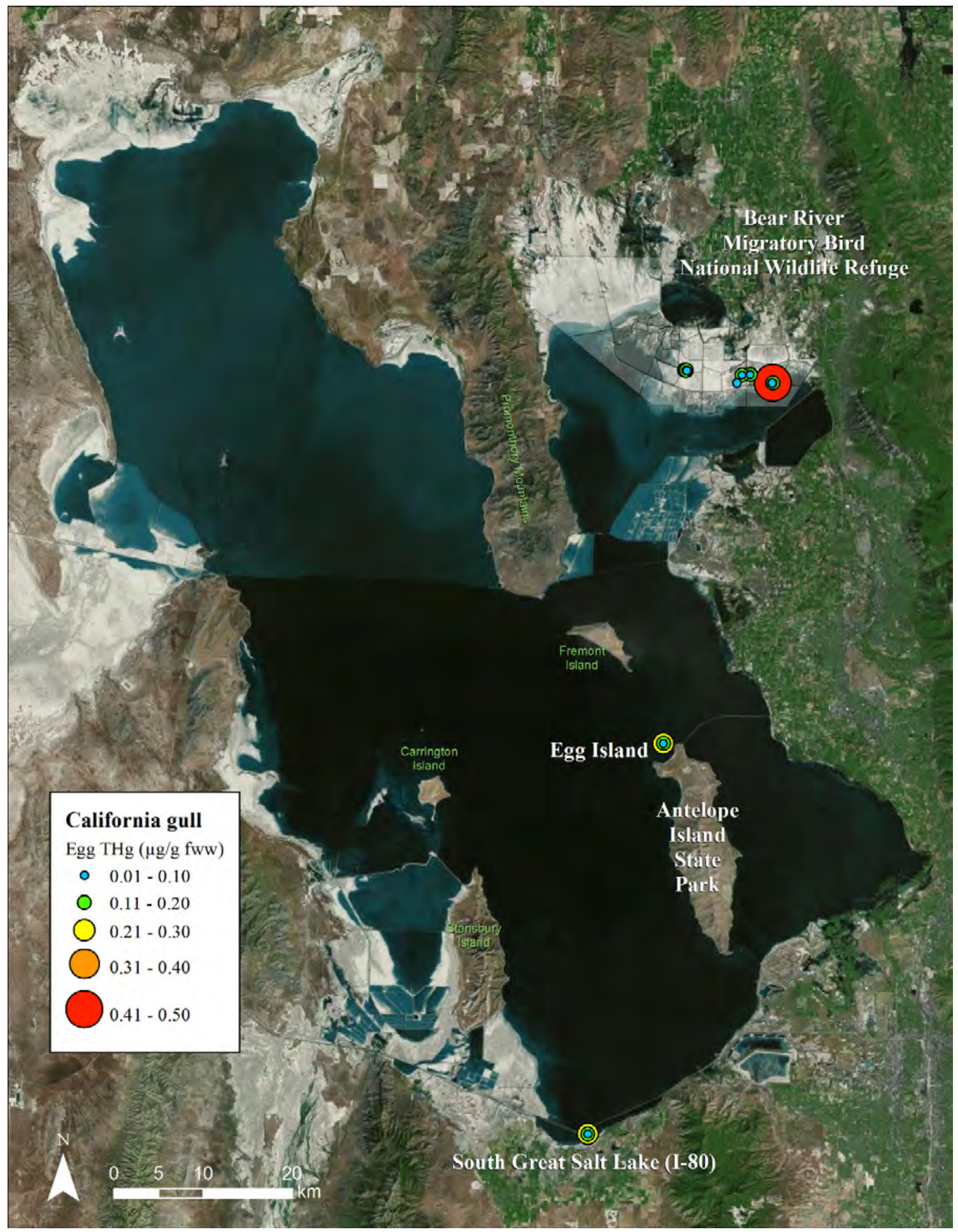

Figure A-10. Total mercury concentrations (THg; $\mu \mathrm{g} / \mathrm{g} \mathrm{fww}$ ) in eggs of California gulls breeding in Great Salt Lake, Utah, 2010-2012. 


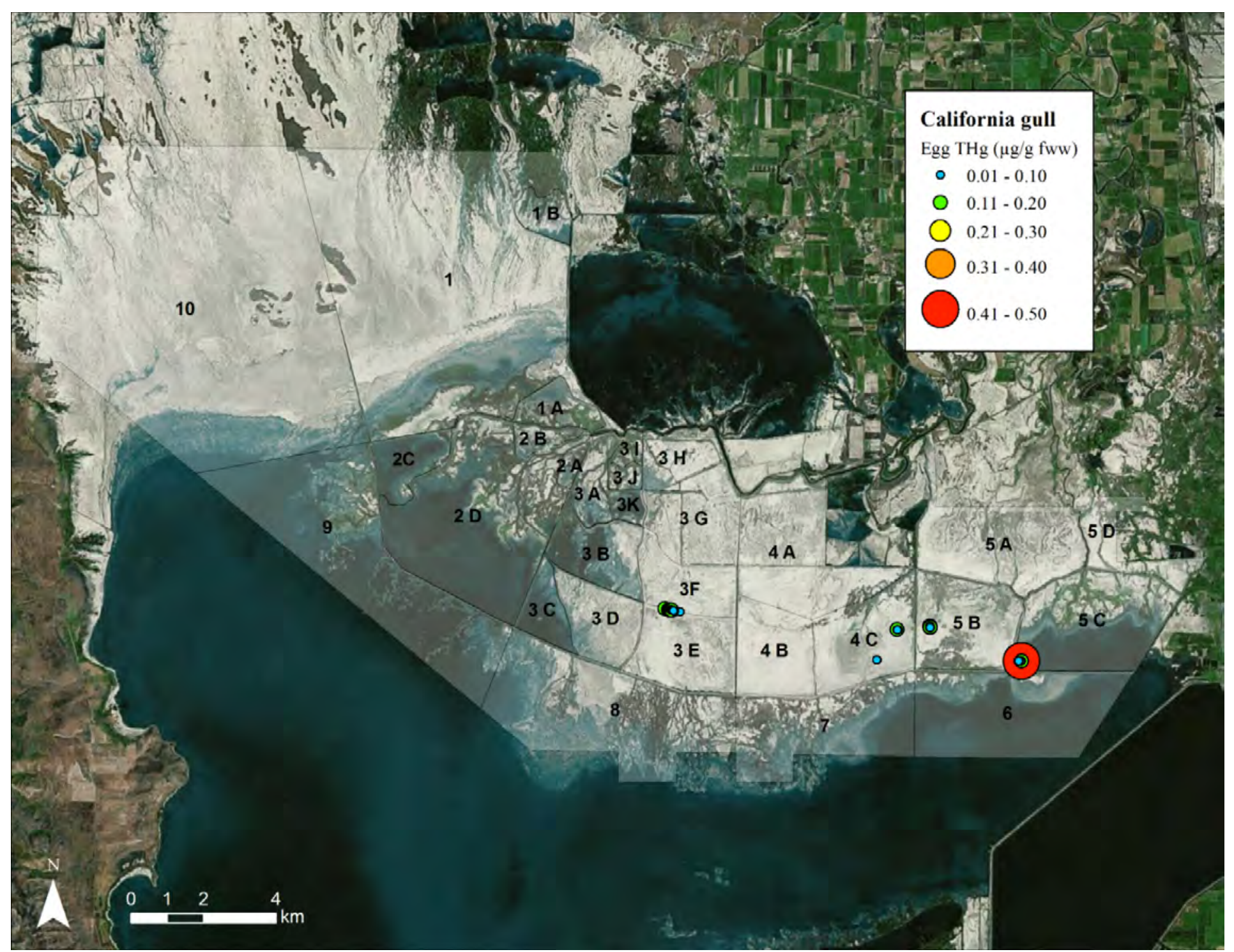

Figure A-11. Total mercury concentrations (THg; $\mu \mathrm{g} / \mathrm{g} \mathrm{fww}$ ) in eggs of California gulls breeding at Bear River Migratory Bird Refuge in Great Salt Lake, Utah, 2010-2012. 


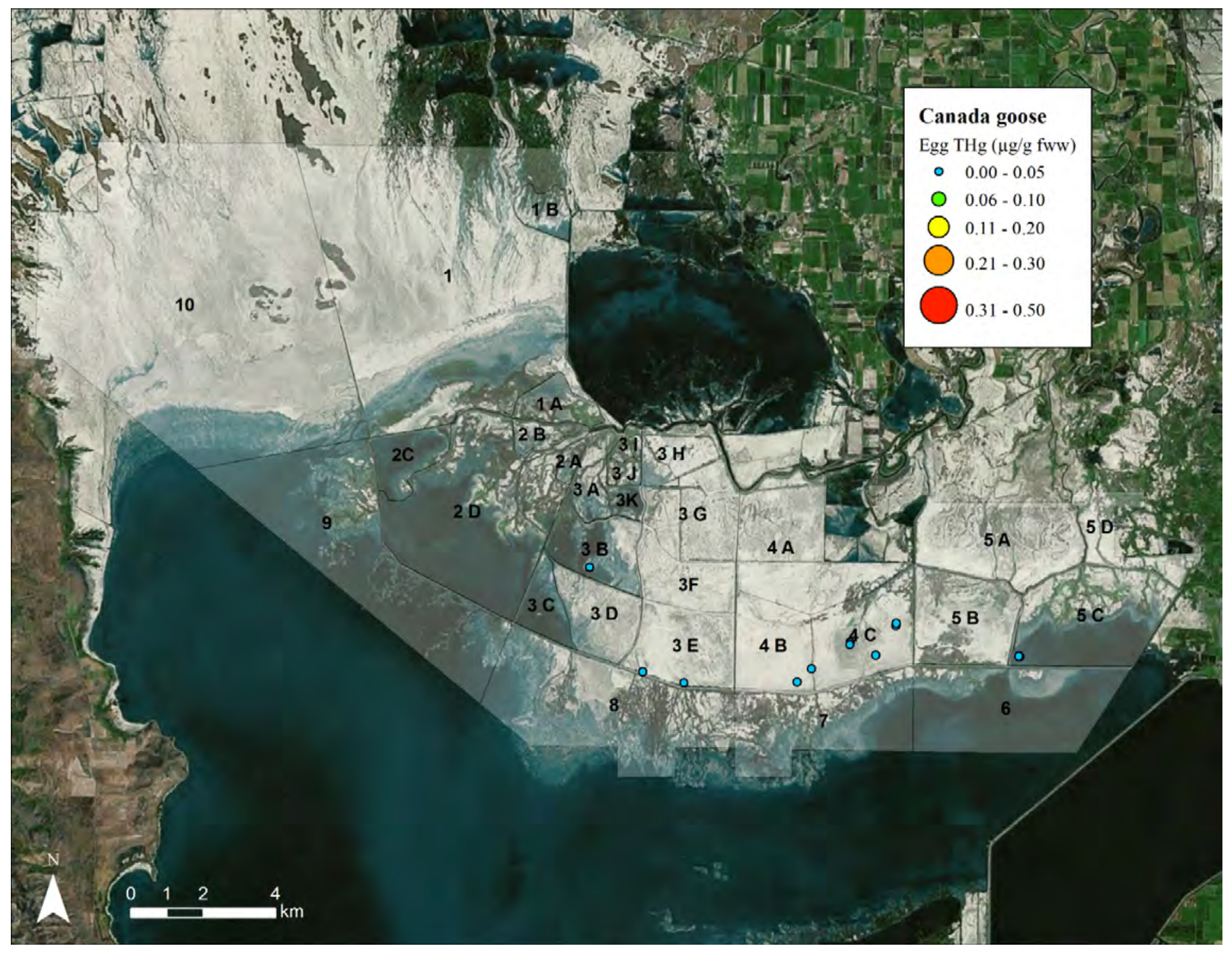

Figure A-12. Total mercury concentrations ( $\mathrm{THg} ; \mu \mathrm{g} / \mathrm{g}$ fww) in eggs of Canada geese breeding at Bear River Migratory Bird Refuge in Great Salt Lake, Utah, 2010-2012. 


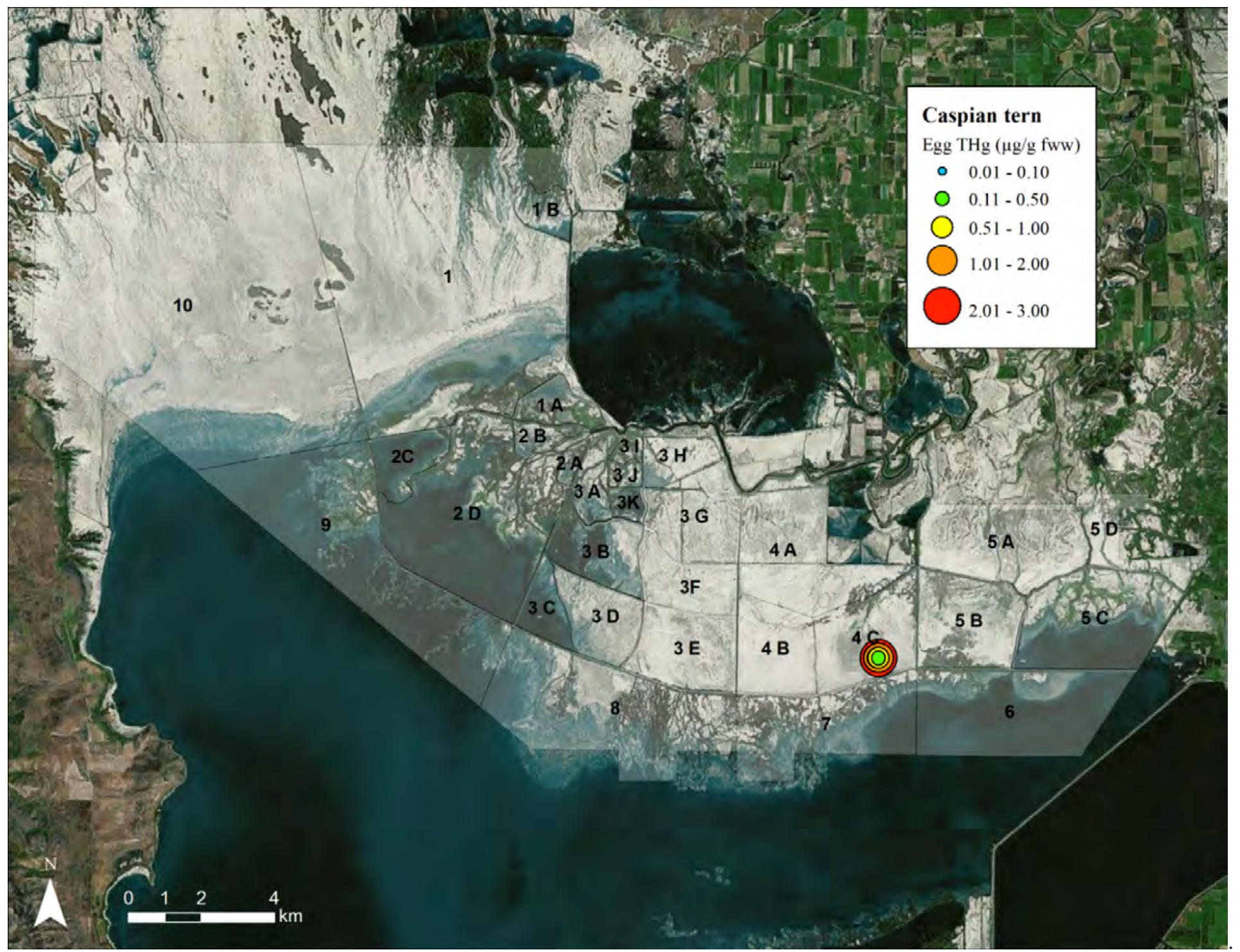

Figure A-13. Total mercury concentrations (THg; $\mu \mathrm{g} / \mathrm{g}$ fww) in eggs of Caspian terns breeding at Bear River Migratory Bird Refuge in Great Salt Lake, Utah, 2010-2012. 


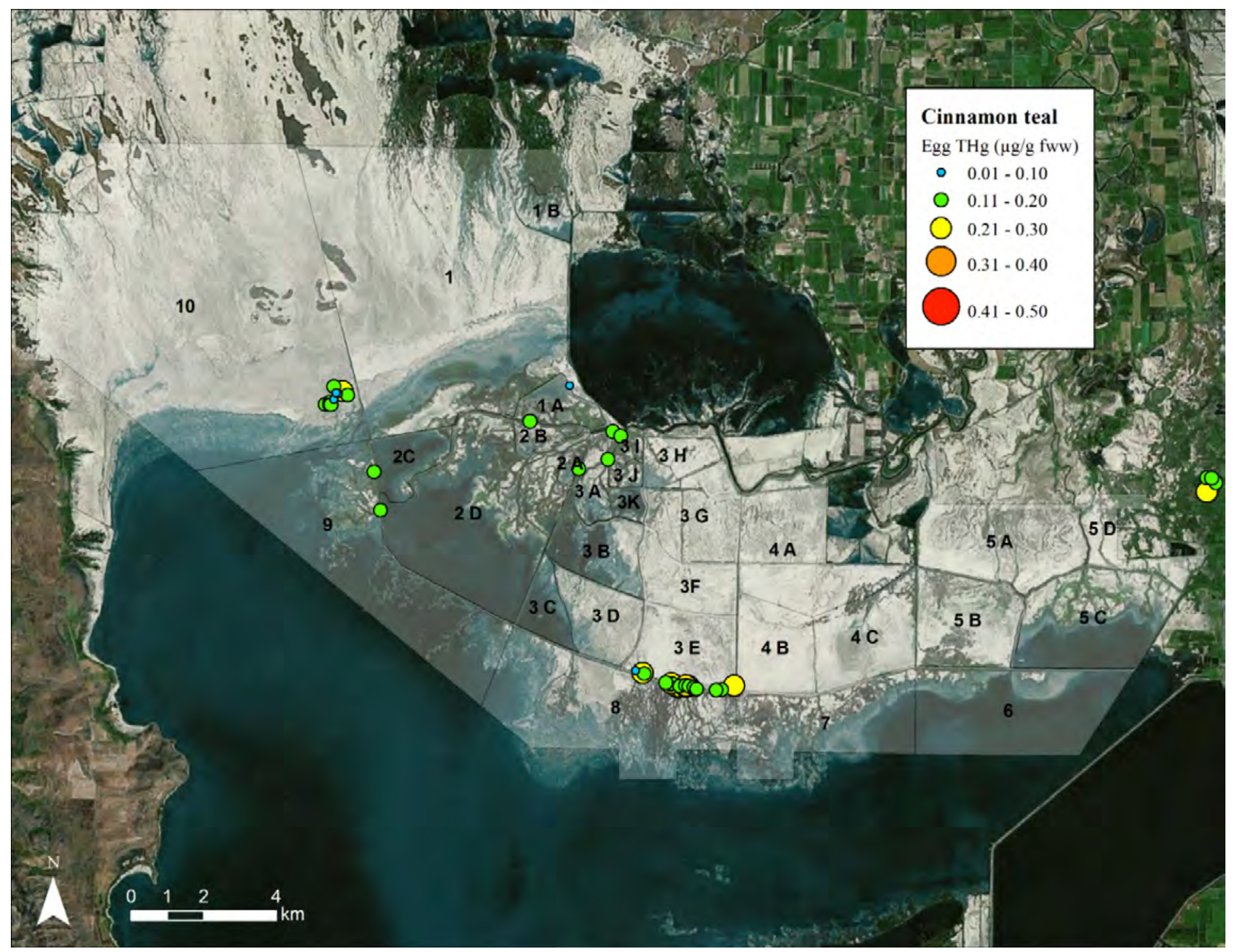

Figure A-14. Total mercury concentrations (THg; $\mu \mathrm{g} / \mathrm{g} \mathrm{fww}$ ) in eggs of cinnamon teal breeding at Bear River Migratory Bird Refuge in Great Salt Lake, Utah, 2010-2012. 


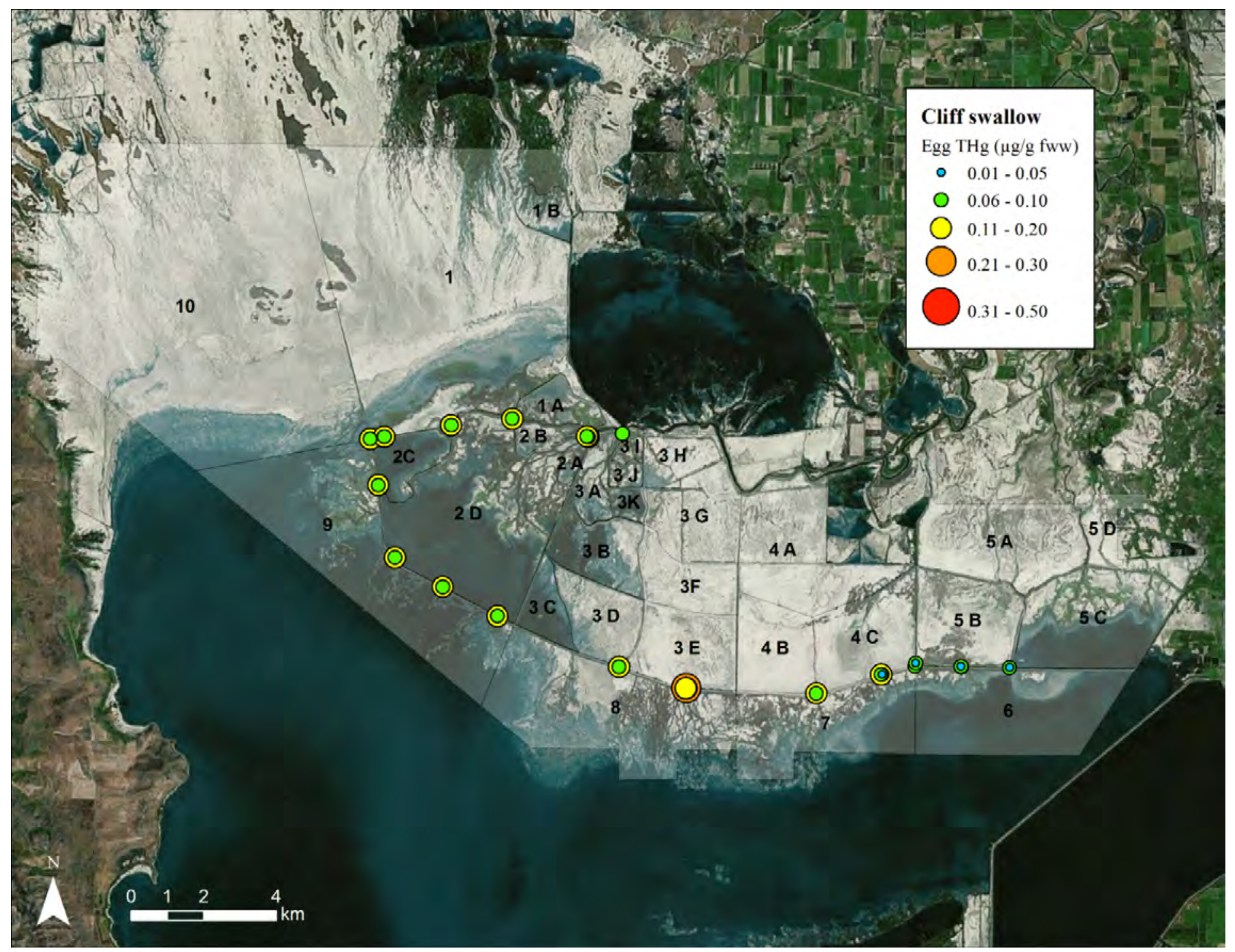

Figure A-15. Total mercury concentrations (THg; $\mu \mathrm{g} / \mathrm{g} \mathrm{fww}$ ) in eggs of cliff swallows breeding at Bear River Migratory Bird Refuge in Great Salt Lake, Utah, 2010-2012. 


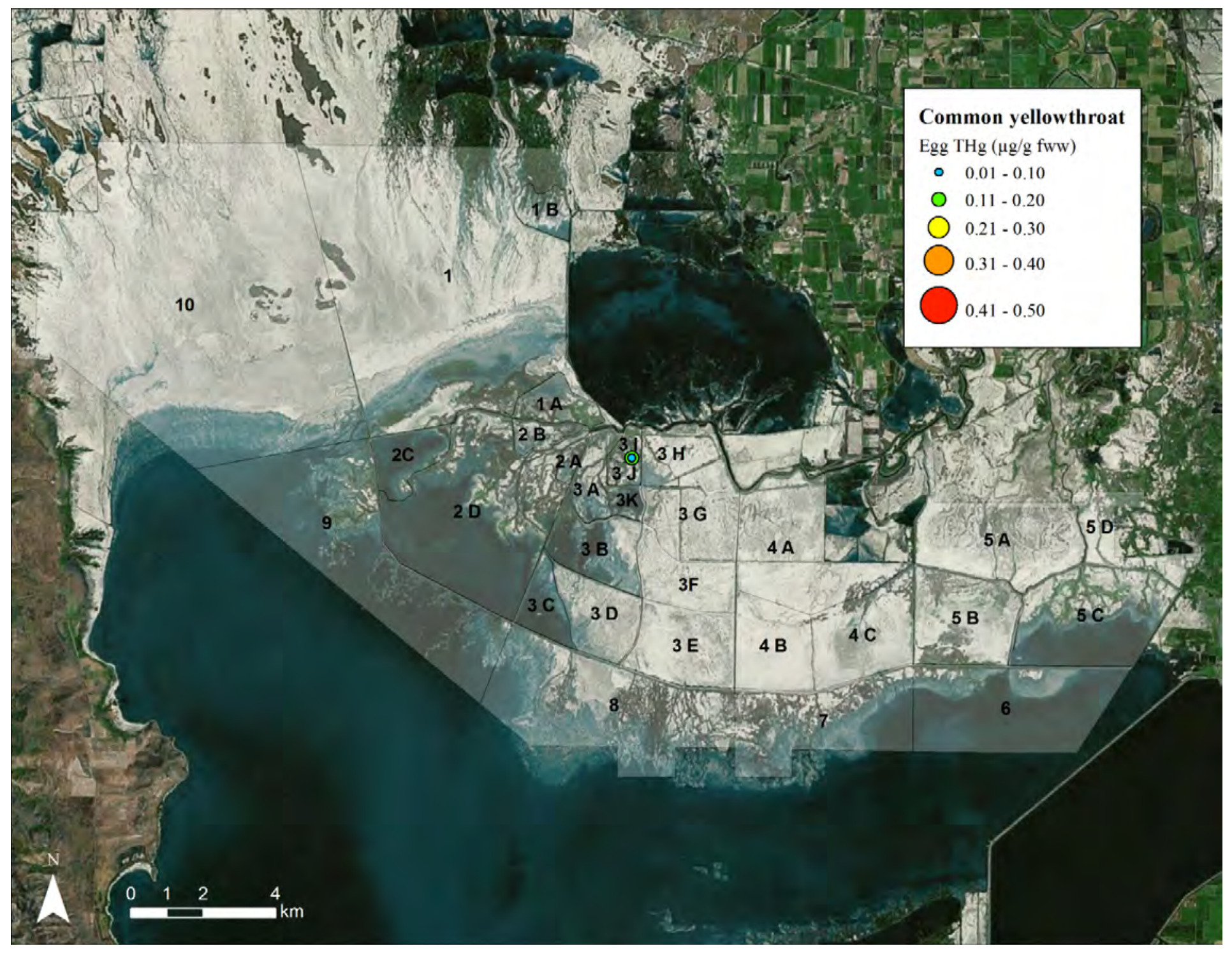

Figure A-16. Total mercury concentrations (THg; $\mu \mathrm{g} / \mathrm{g} \mathrm{fww)}$ in eggs of common yellowthroats breeding at Bear River Migratory Bird Refuge in Great Salt Lake, Utah, 2010-2012. 


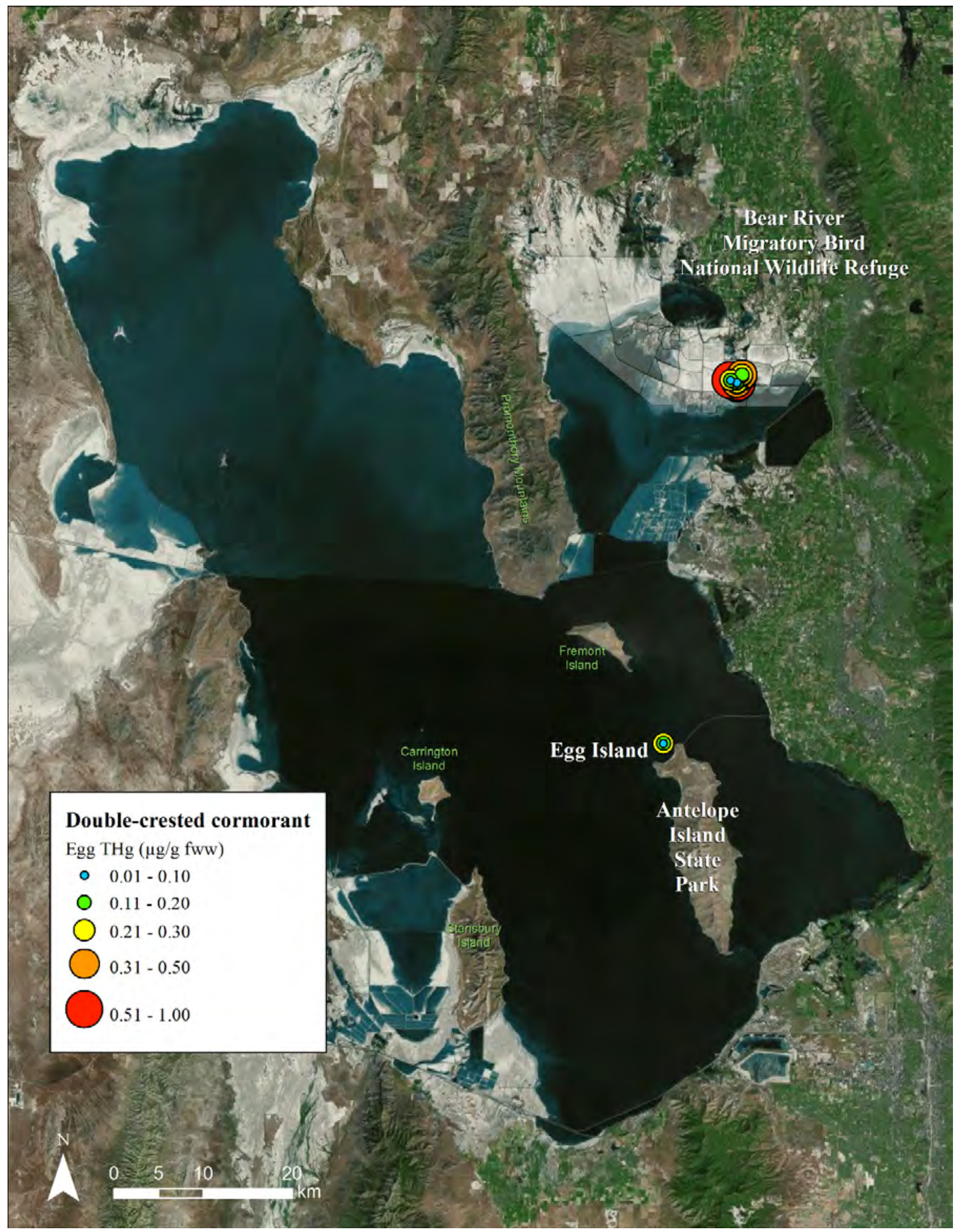

Figure A-17. Total mercury concentrations (THg; $\mu \mathrm{g} / \mathrm{g} \mathrm{fww}$ ) in eggs of double-crested cormorants breeding in Great Salt Lake, Utah, 2010-2012. 


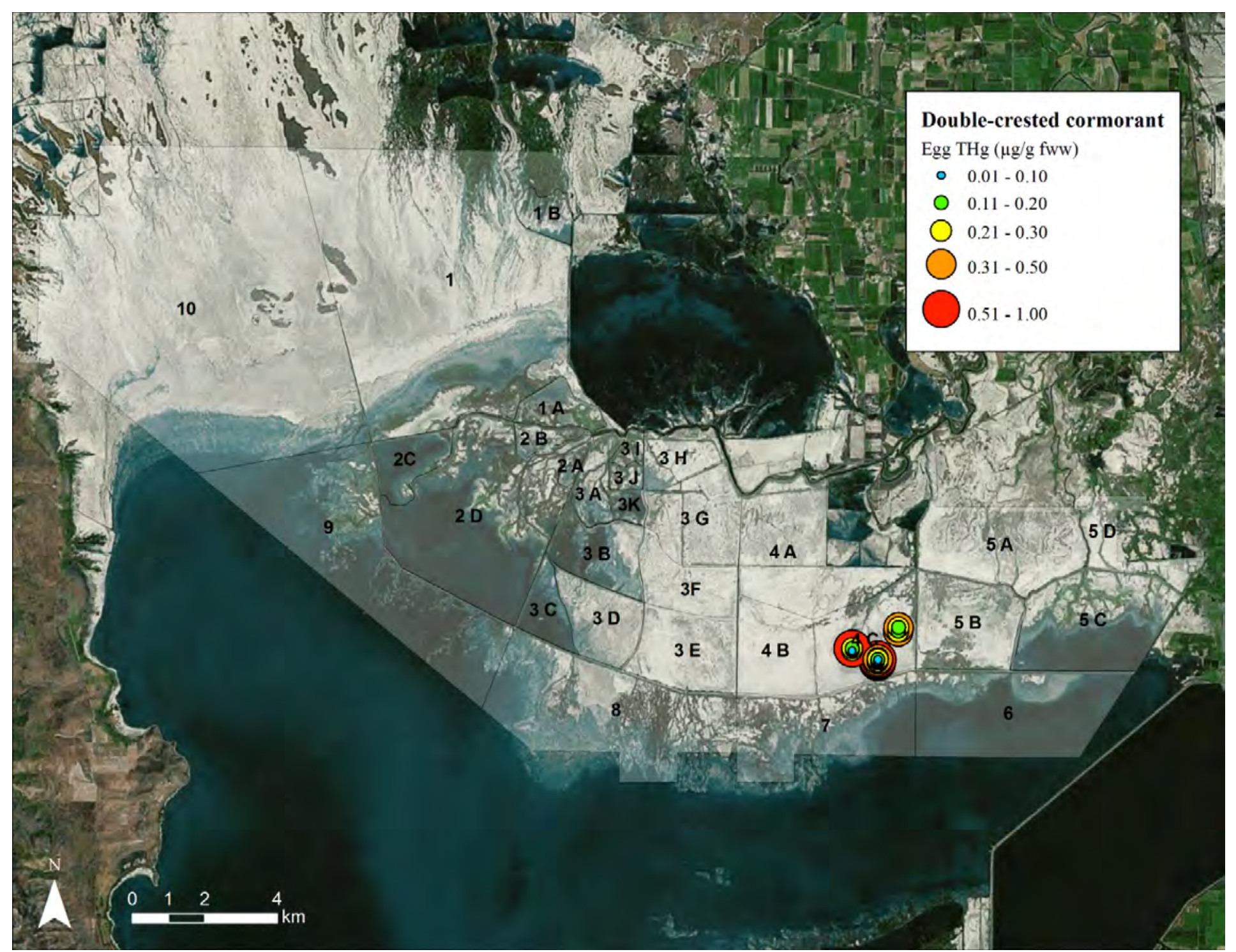

Figure A-18. Total mercury concentrations (THg; $\mu \mathrm{g} / \mathrm{g}$ fww) in eggs of double-crested cormorants breeding at Bear River Migratory Bird Refuge in Great Salt Lake, Utah, 2010-2012. 


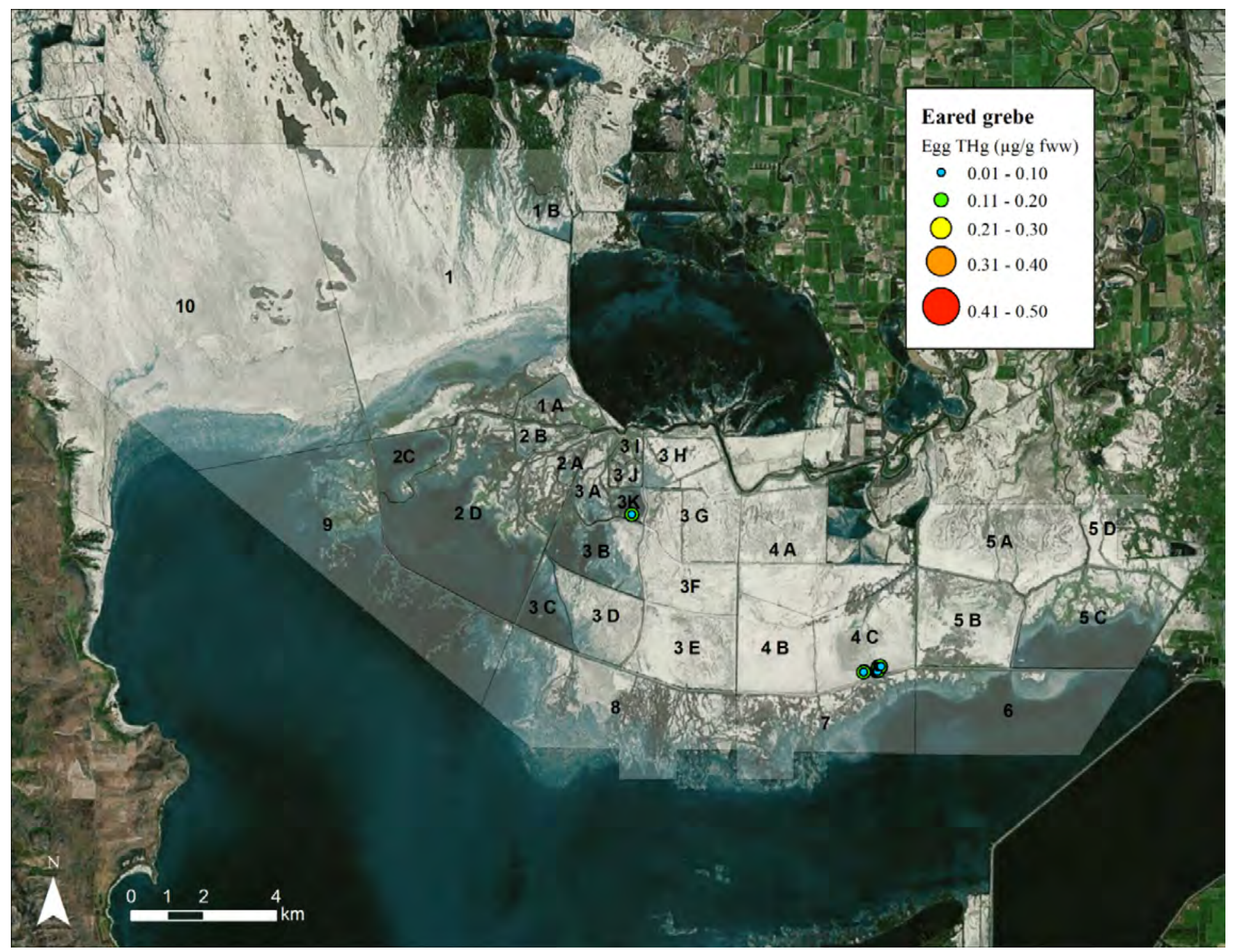

Figure A-19. Total mercury concentrations ( $\mathrm{THg} ; \mu \mathrm{g} / \mathrm{g}$ fww) in eggs of eared grebes breeding at Bear River Migratory Bird Refuge in Great Salt Lake, Utah, 2010-2012. 


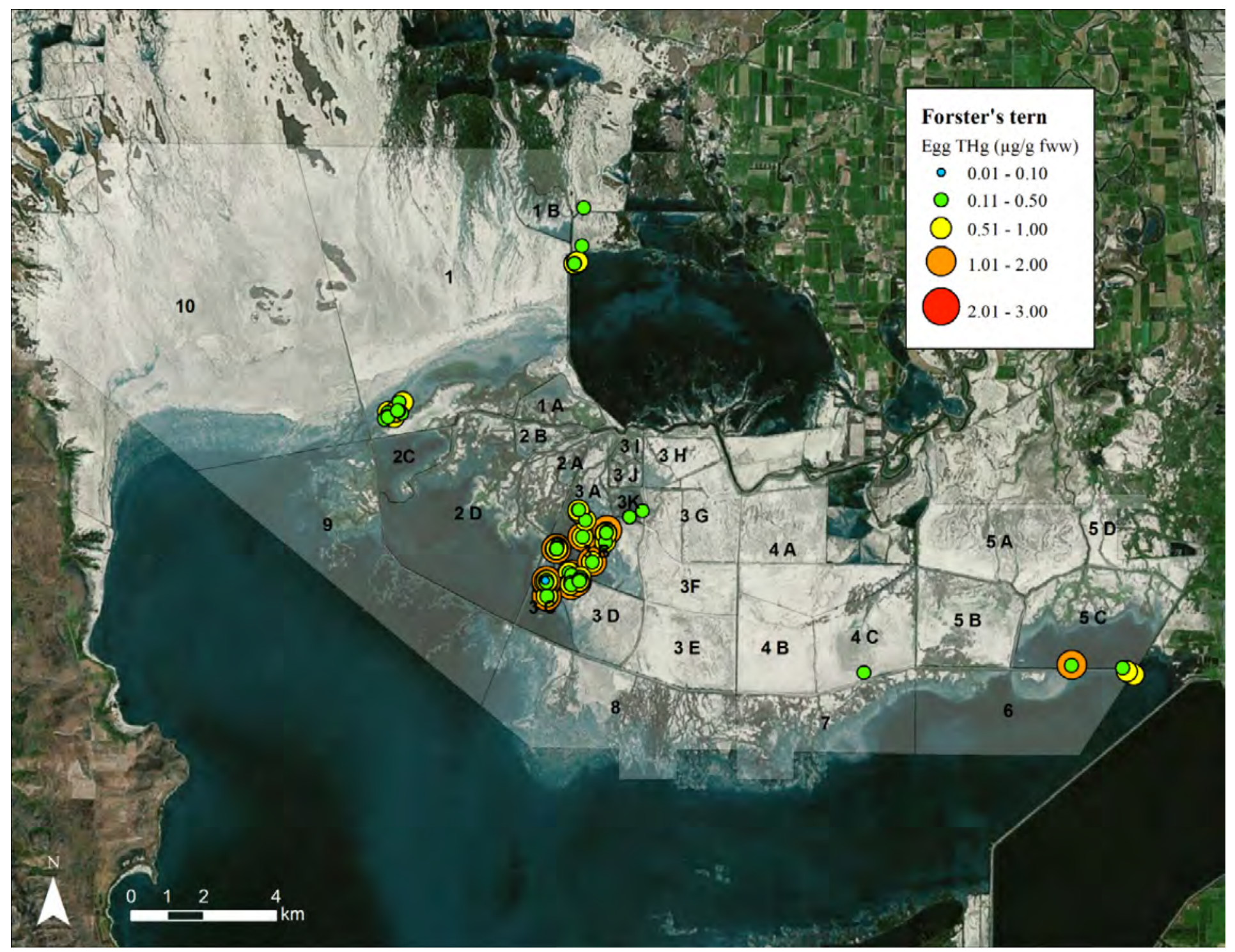

Figure A-20. Total mercury concentrations ( $\mathrm{THg} ; \mu \mathrm{g} / \mathrm{g}$ fww) in eggs of Forster's terns breeding at Bear River Migratory Bird Refuge in Great Salt Lake, Utah, 2010-2012. 


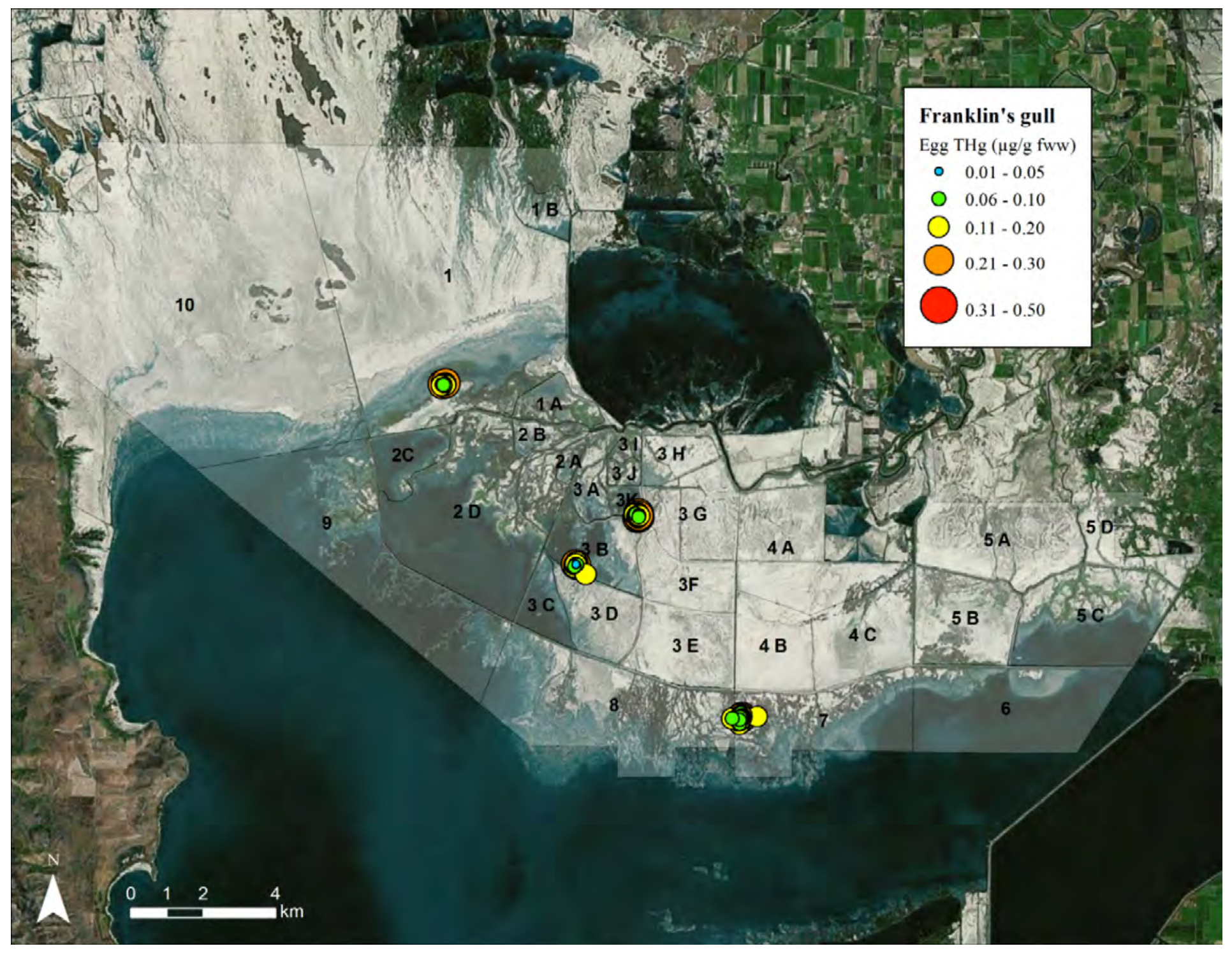

Figure A-21. Total mercury concentrations (THg; $\mu \mathrm{g} / \mathrm{g}$ fww) in eggs of Franklin's gulls breeding at Bear River Migratory Bird Refuge in Great Salt Lake, Utah, 2010-2012. 


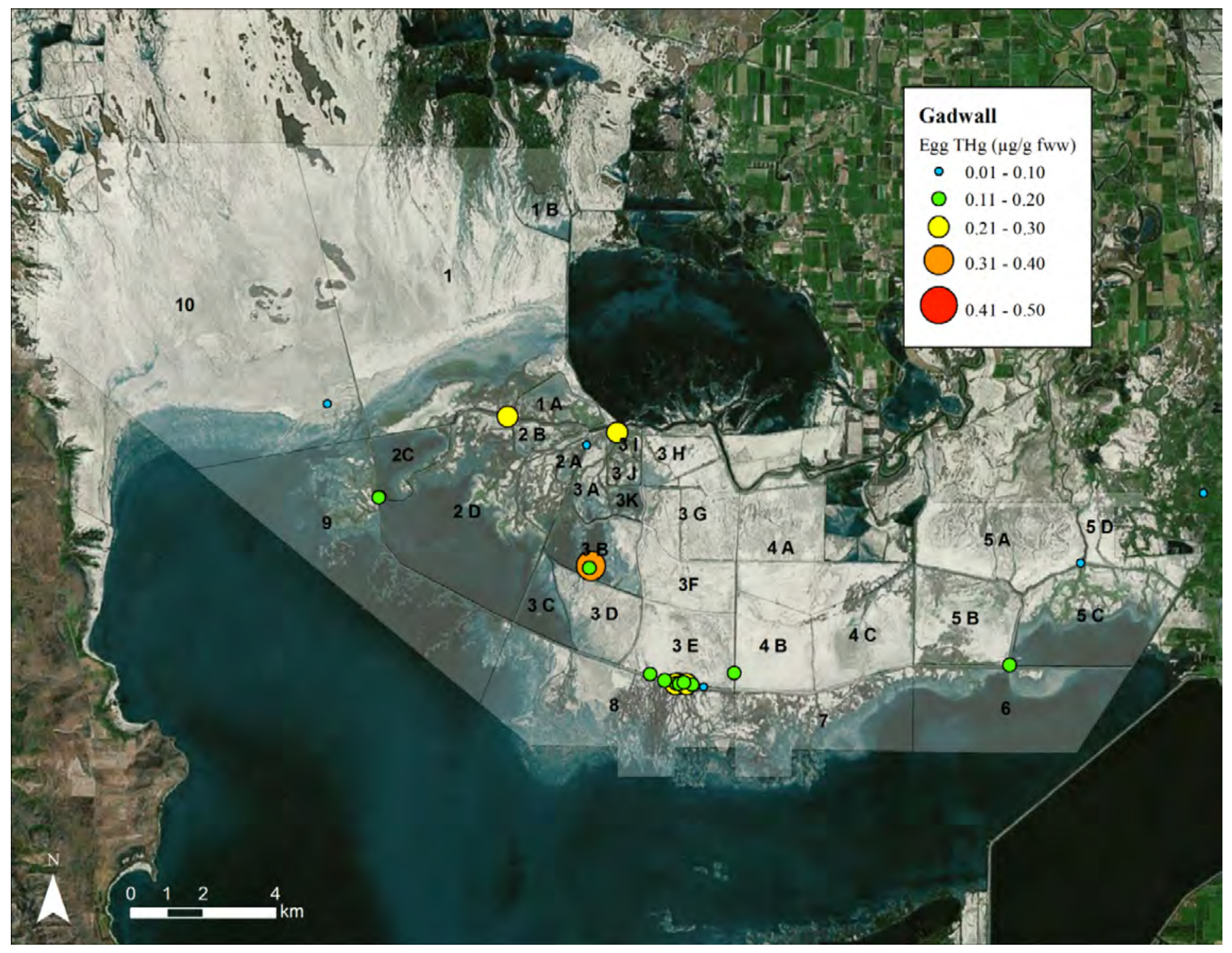

Figure A-22. Total mercury concentrations (THg; $\mu \mathrm{g} / \mathrm{g} \mathrm{fww}$ ) in eggs of gadwall breeding at Bear River Migratory Bird Refuge in Great Salt Lake, Utah, 2010-2012. 


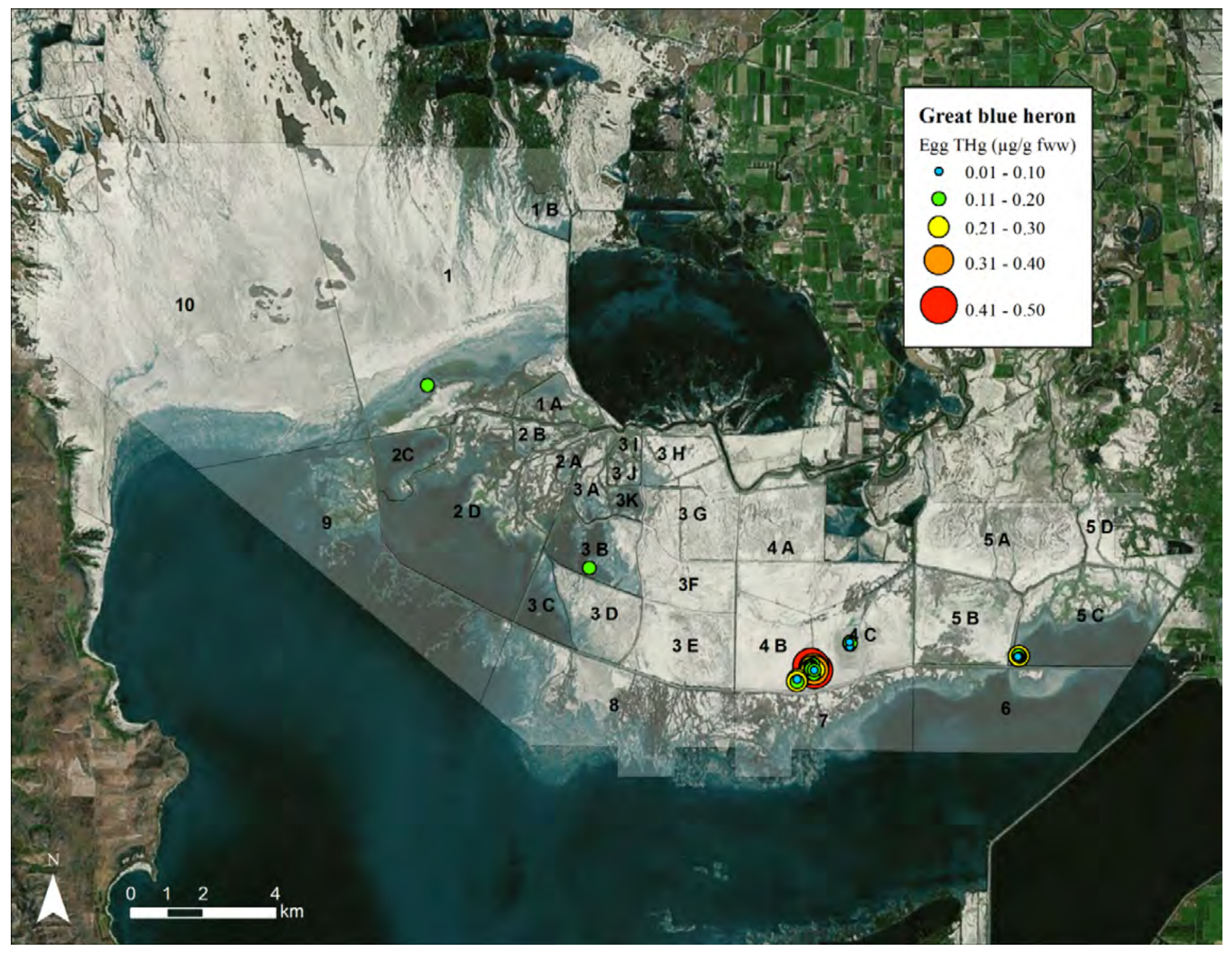

Figure A-23. Total mercury concentrations (THg; $\mu \mathrm{g} / \mathrm{g} \mathrm{fww}$ ) in eggs of great blue herons breeding at Bear River Migratory Bird Refuge in Great Salt Lake, Utah, 2010-12. 


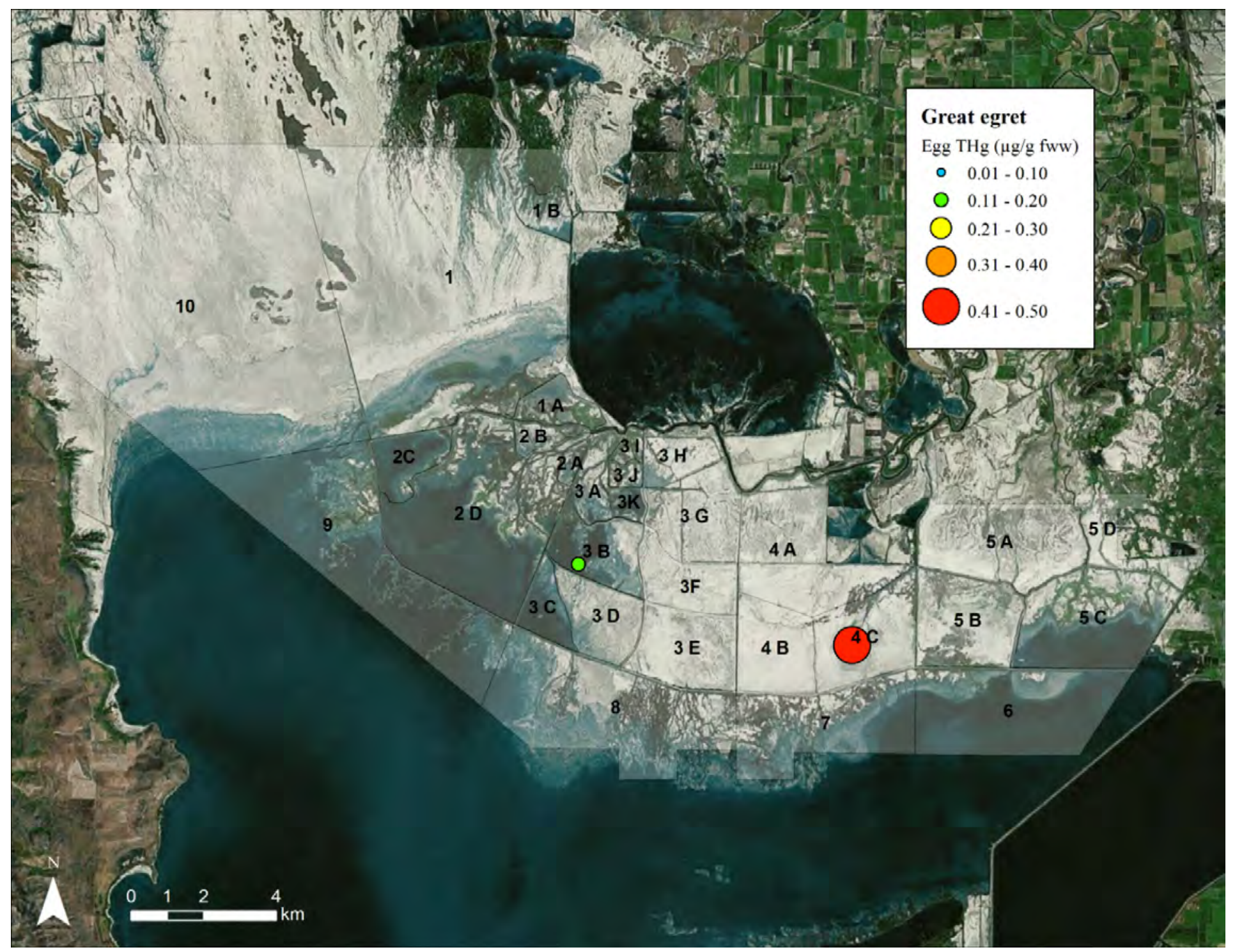

Figure A-24. Total mercury concentrations (THg; $\mu \mathrm{g} / \mathrm{g} \mathrm{fww)} \mathrm{in} \mathrm{eggs} \mathrm{of} \mathrm{great} \mathrm{egrets} \mathrm{breeding} \mathrm{at} \mathrm{Bear} \mathrm{River} \mathrm{Migratory} \mathrm{Bird} \mathrm{Refuge} \mathrm{in} \mathrm{Great} \mathrm{Salt} \mathrm{Lake,} \mathrm{Utah,}$ 2010-2012. 


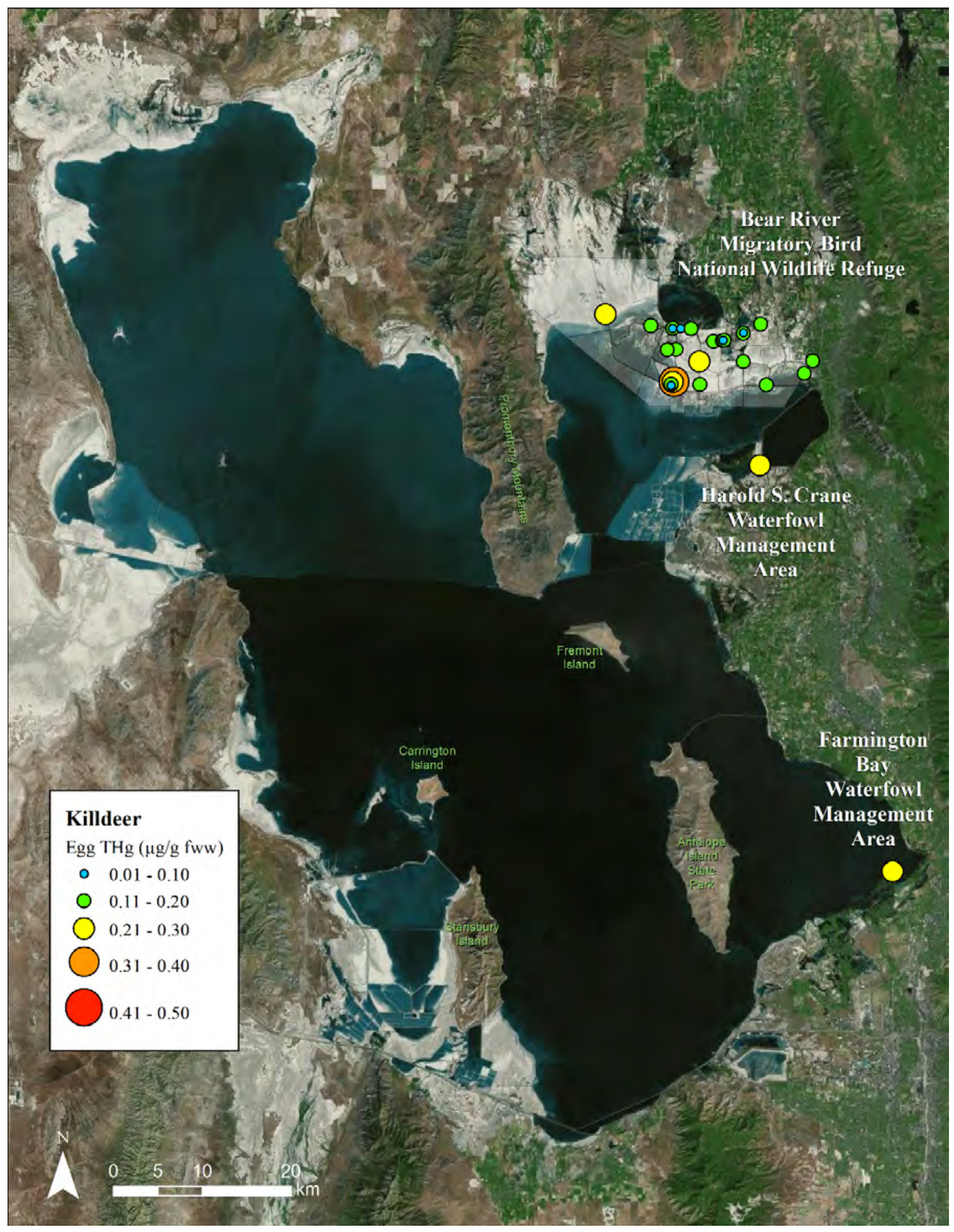

Figure A-25. Total mercury concentrations (THg; $\mu \mathrm{g} / \mathrm{g} \mathrm{fww}$ ) in eggs of killdeer breeding in Great Salt Lake, Utah, 2010-2012. 


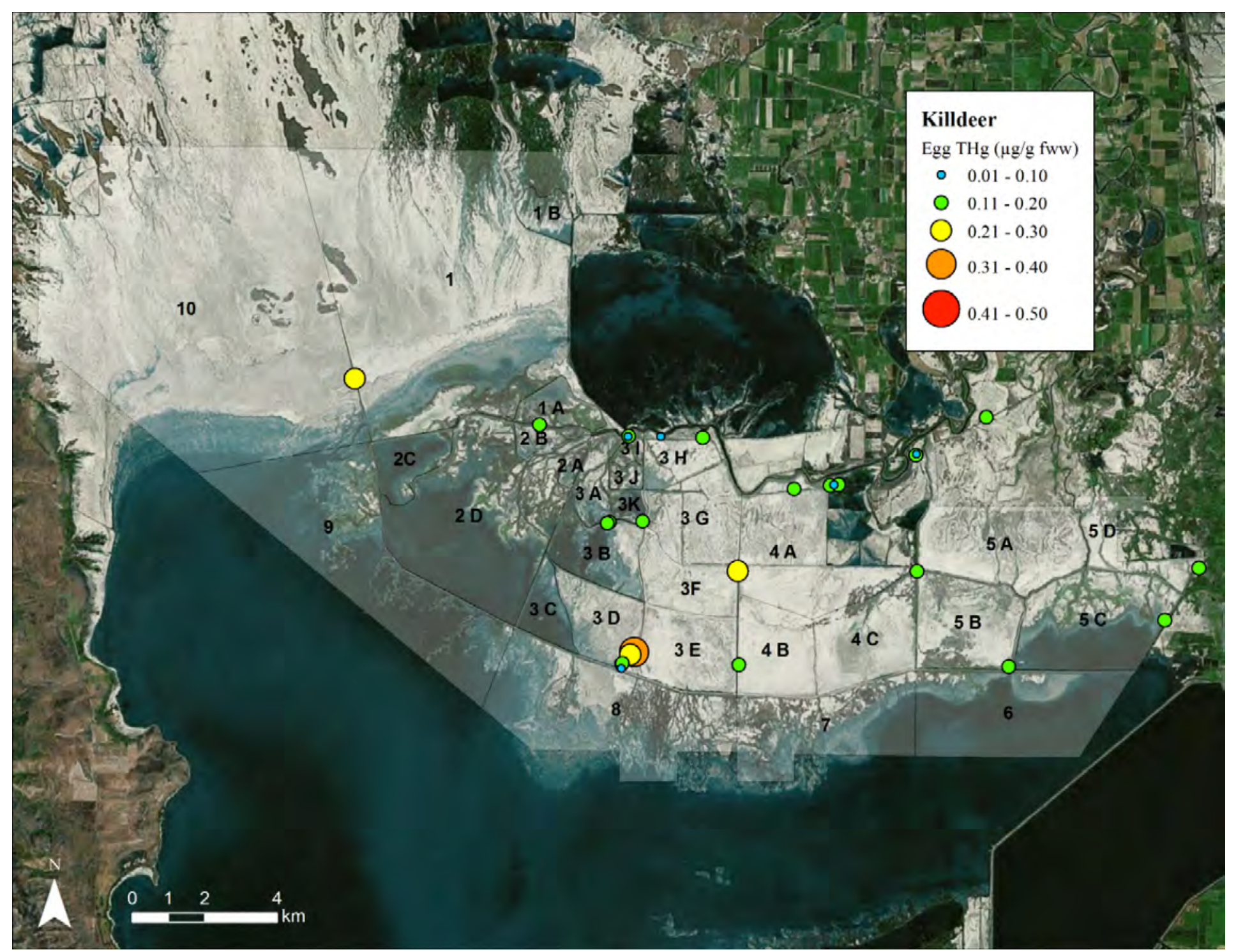

Figure A-26. Total mercury concentrations (THg; $\mu \mathrm{g} / \mathrm{g}$ fww) in eggs of killdeer breeding at Bear River Migratory Bird Refuge in Great Salt Lake, Utah, 2010-2012. 


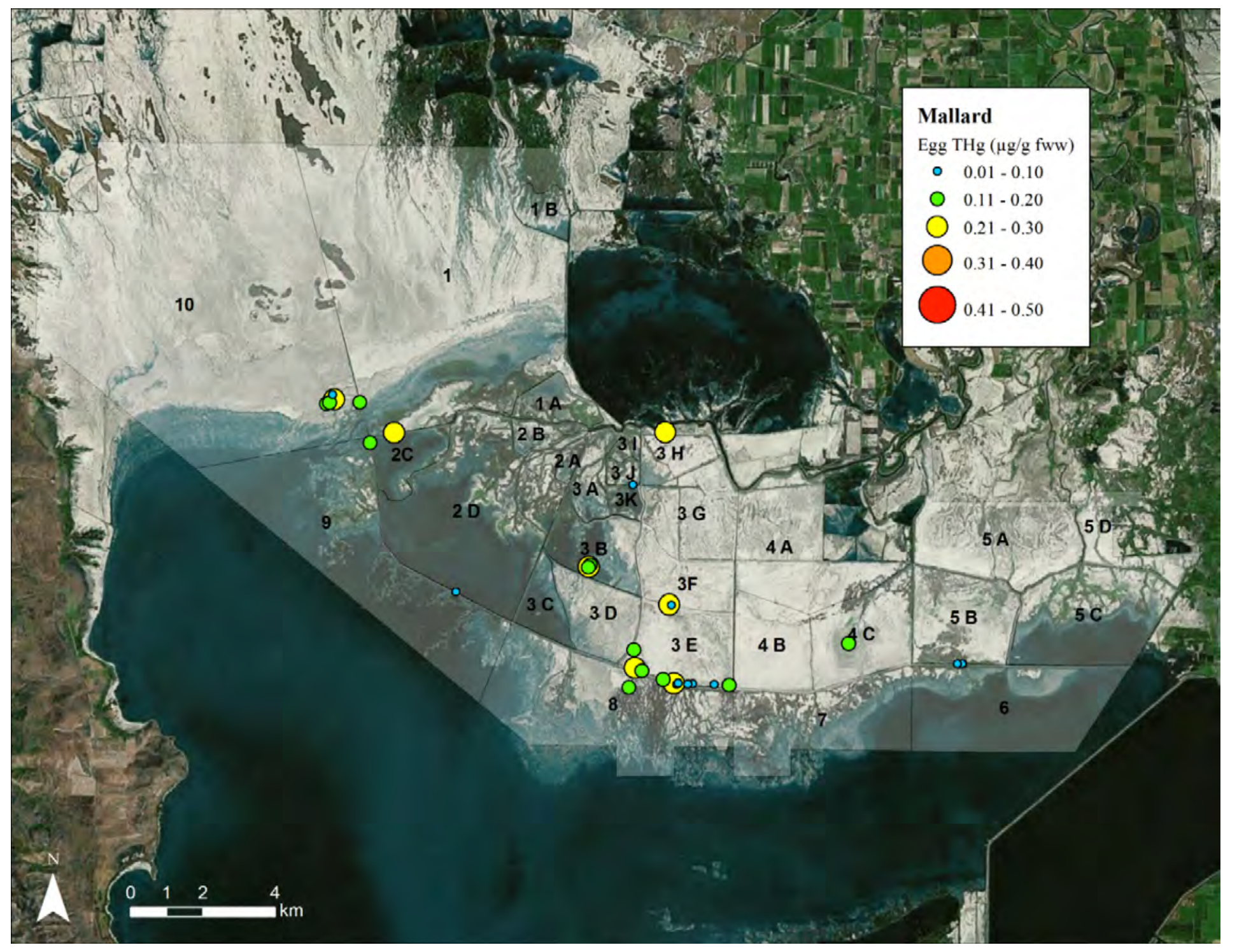

Figure A-27. Total mercury concentrations (THg; $\mu \mathrm{g} / \mathrm{g} \mathrm{fww)}$ ) in eggs mallard breeding at Bear River Migratory Bird Refuge in Great Salt Lake, Utah, $2010-2012$. 


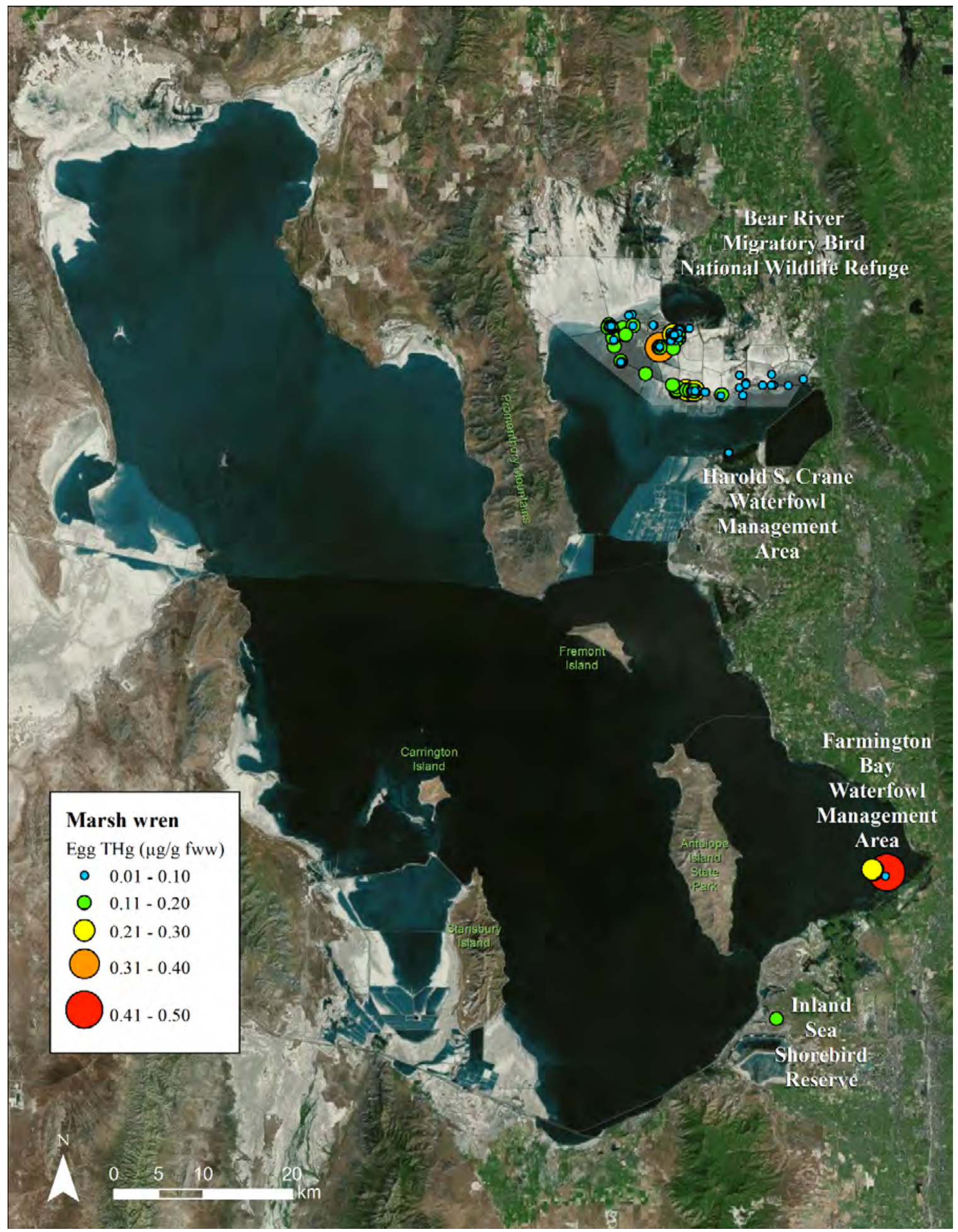

Figure A-28. Total mercury concentrations (THg; $\mu \mathrm{g} / \mathrm{g} \mathrm{fww}$ ) in eggs marsh wrens breeding in Great Salt Lake, Utah, 2010-2012. 


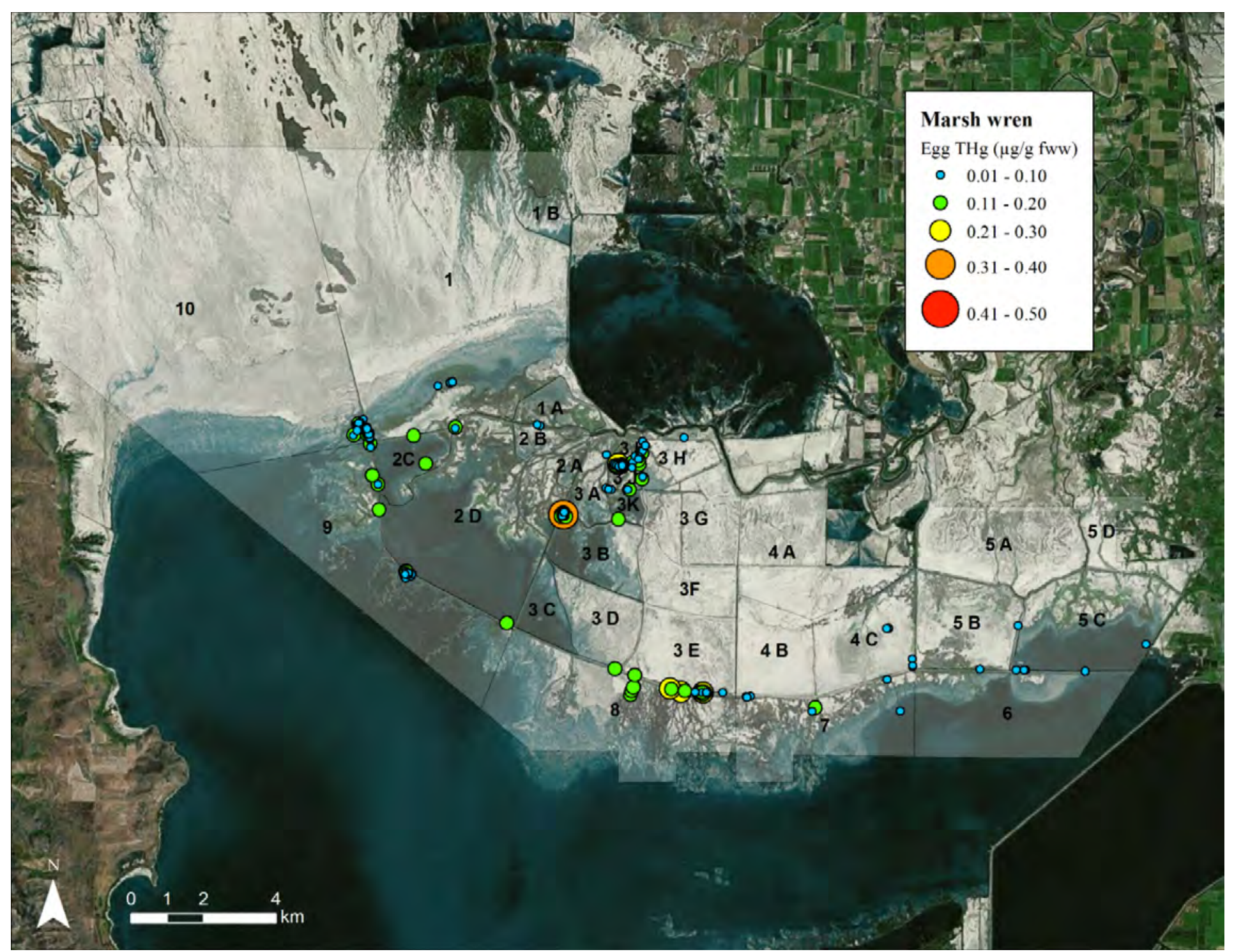

Figure A-29. Total mercury concentrations ( $\mathrm{THg} ; \mu \mathrm{g} / \mathrm{g} \mathrm{fww}$ ) in eggs marsh wrens breeding at Bear River Migratory Bird Refuge in Great Salt Lake, Utah, 2010-2012. 


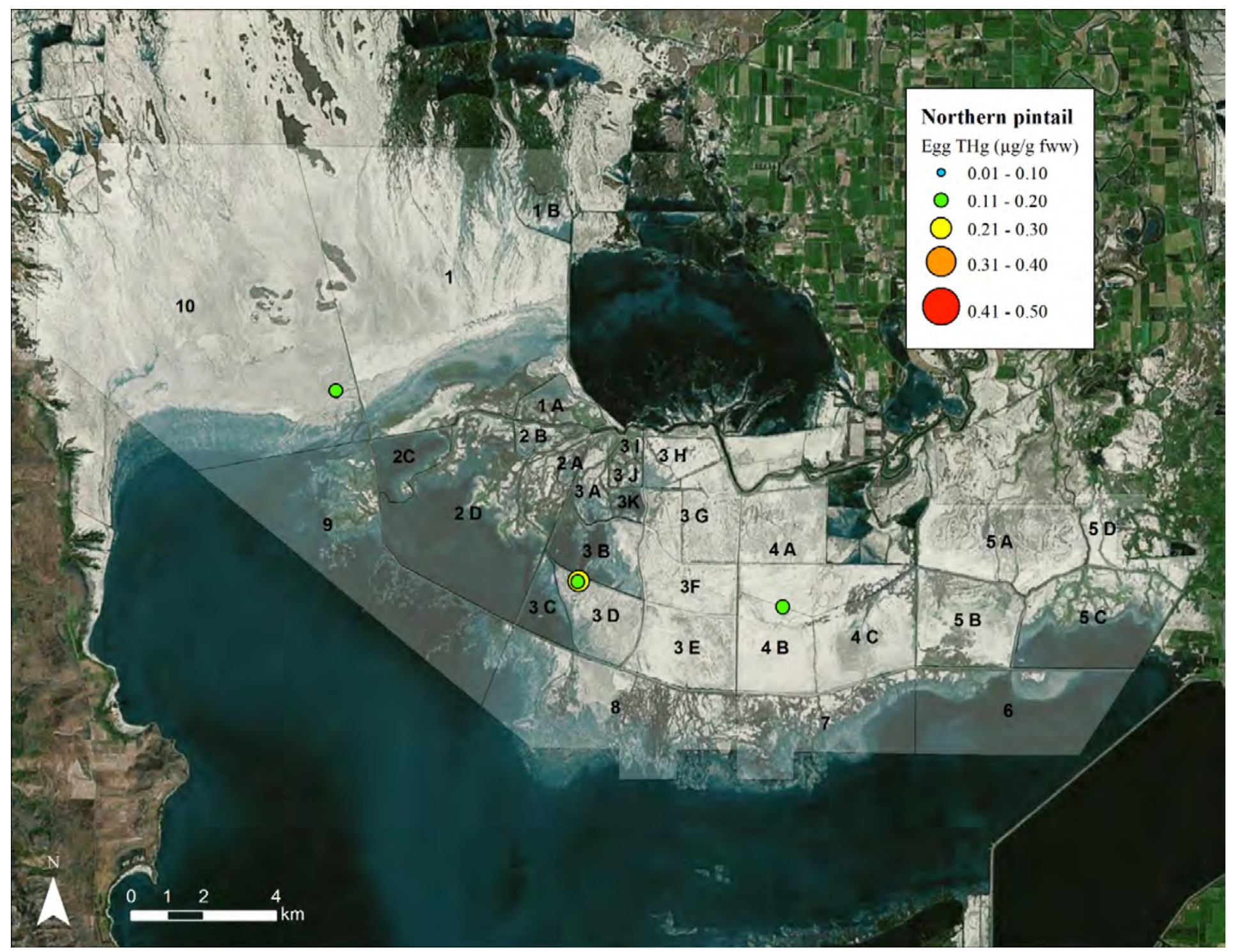

Total mercury concentrations (THg; $\mu \mathrm{g} / \mathrm{g} \mathrm{fww}$ ) in eggs of northern pintail breeding at Bear River Migratory Bird Refuge in Great Salt Lake, Utah, 2010-2012. 


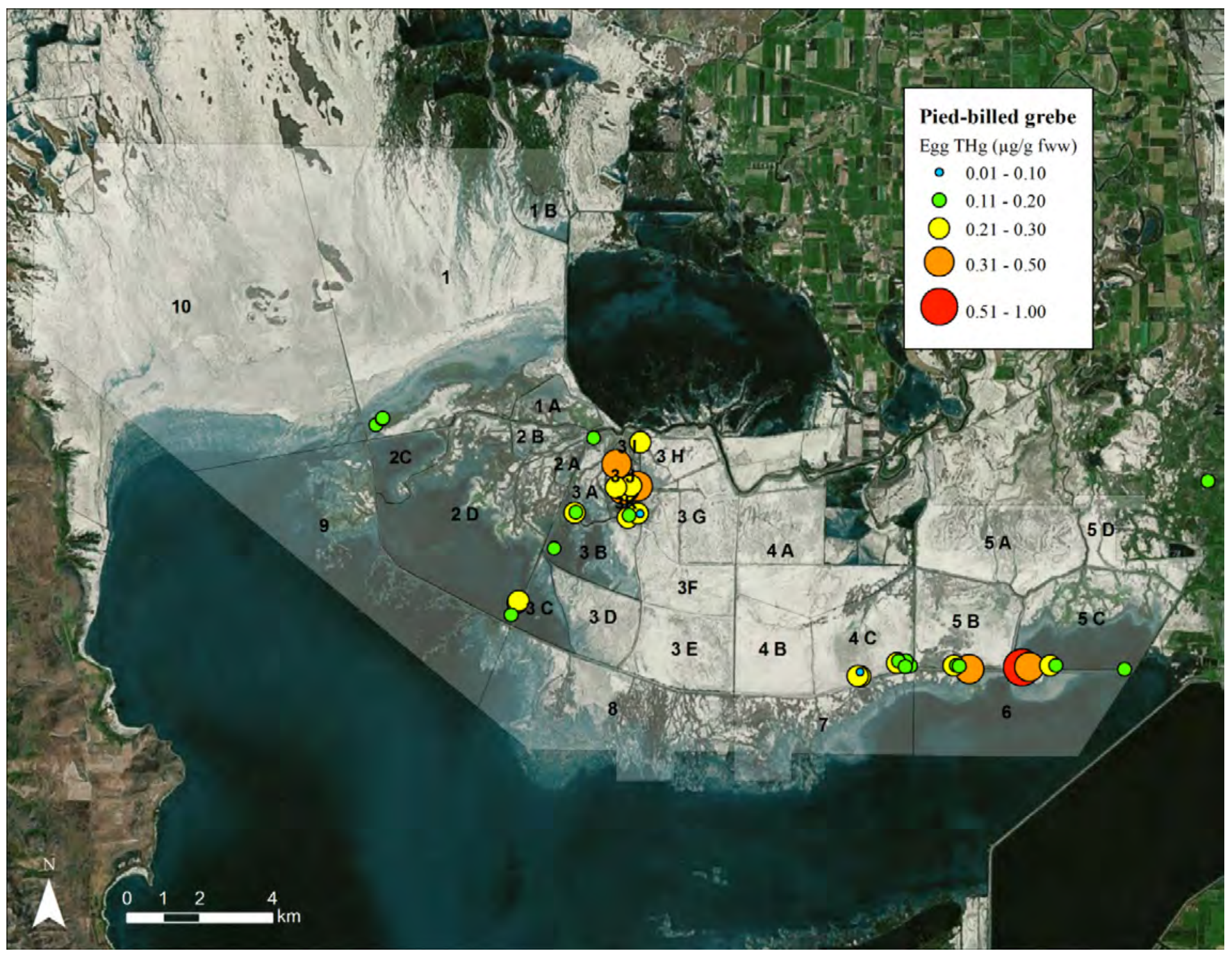

Figure A-30. Total mercury concentrations (THg; $\mu \mathrm{g} / \mathrm{g} \mathrm{fww)}$ in eggs of pied-billed grebes breeding at Bear River Migratory Bird Refuge in Great Salt Lake, Utah, 2010-2012. 


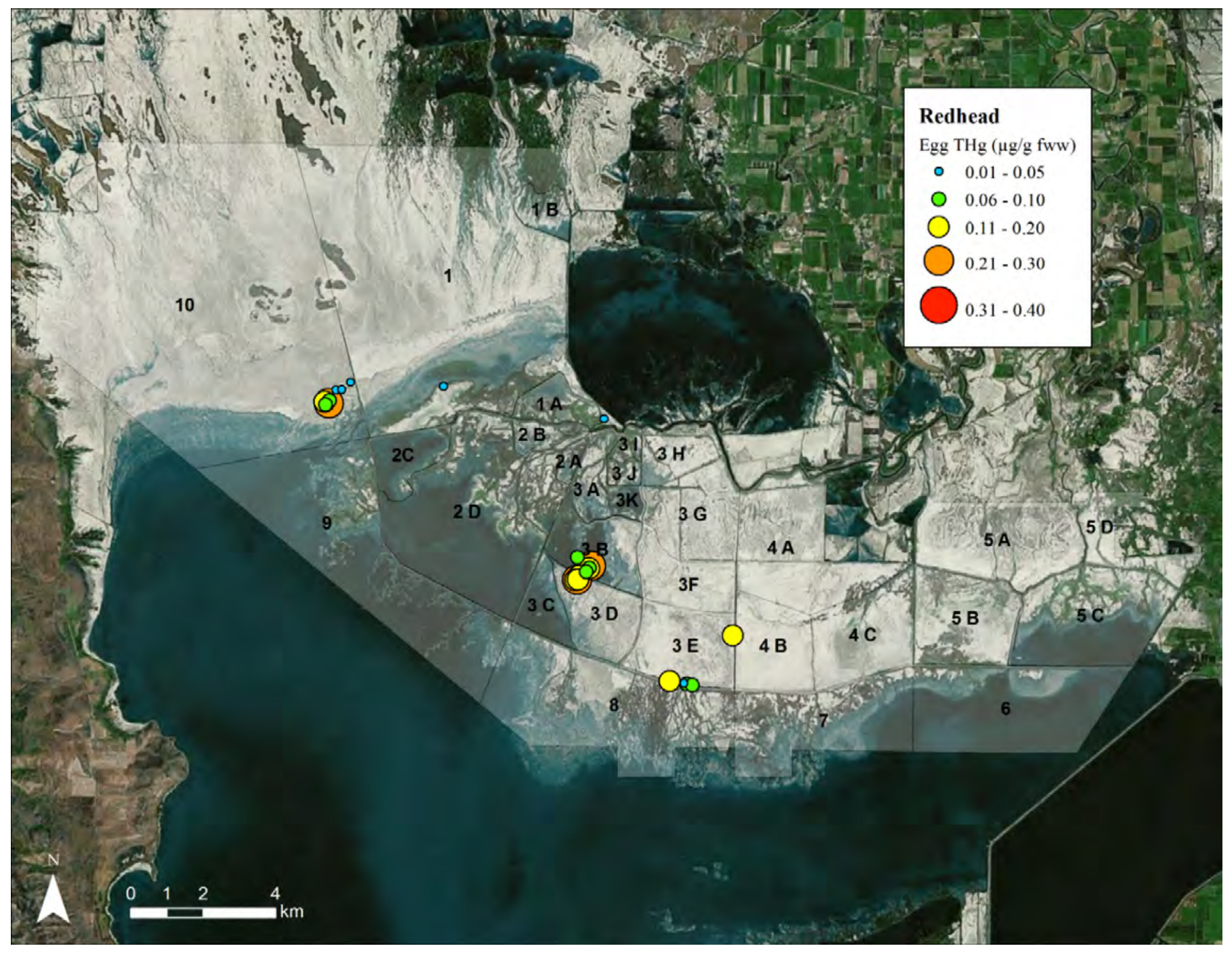

Figure A-31. Total mercury concentrations (THg; $\mu \mathrm{g} / \mathrm{g}$ fww) in eggs of redhead ducks breeding at Bear River Migratory Bird Refuge in Great Salt Lake, Utah, 2010-2012. 


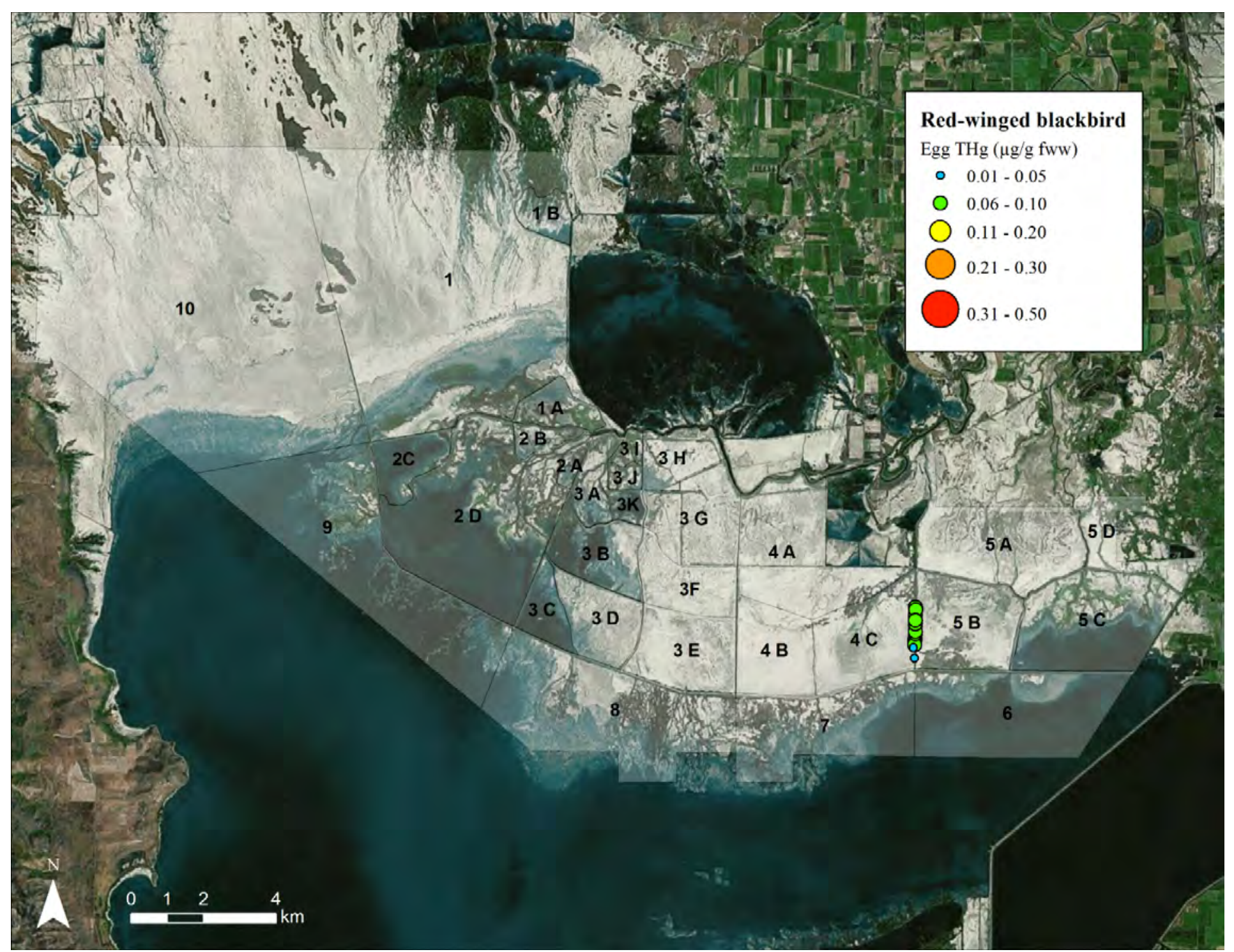

Figure A-32. Total mercury concentrations (THg; $\mu \mathrm{g} / \mathrm{g} \mathrm{fww}$ ) in eggs of red-winged blackbirds breeding at Bear River Migratory Bird Refuge in Great Salt Lake, Utah, 2010-2012. 


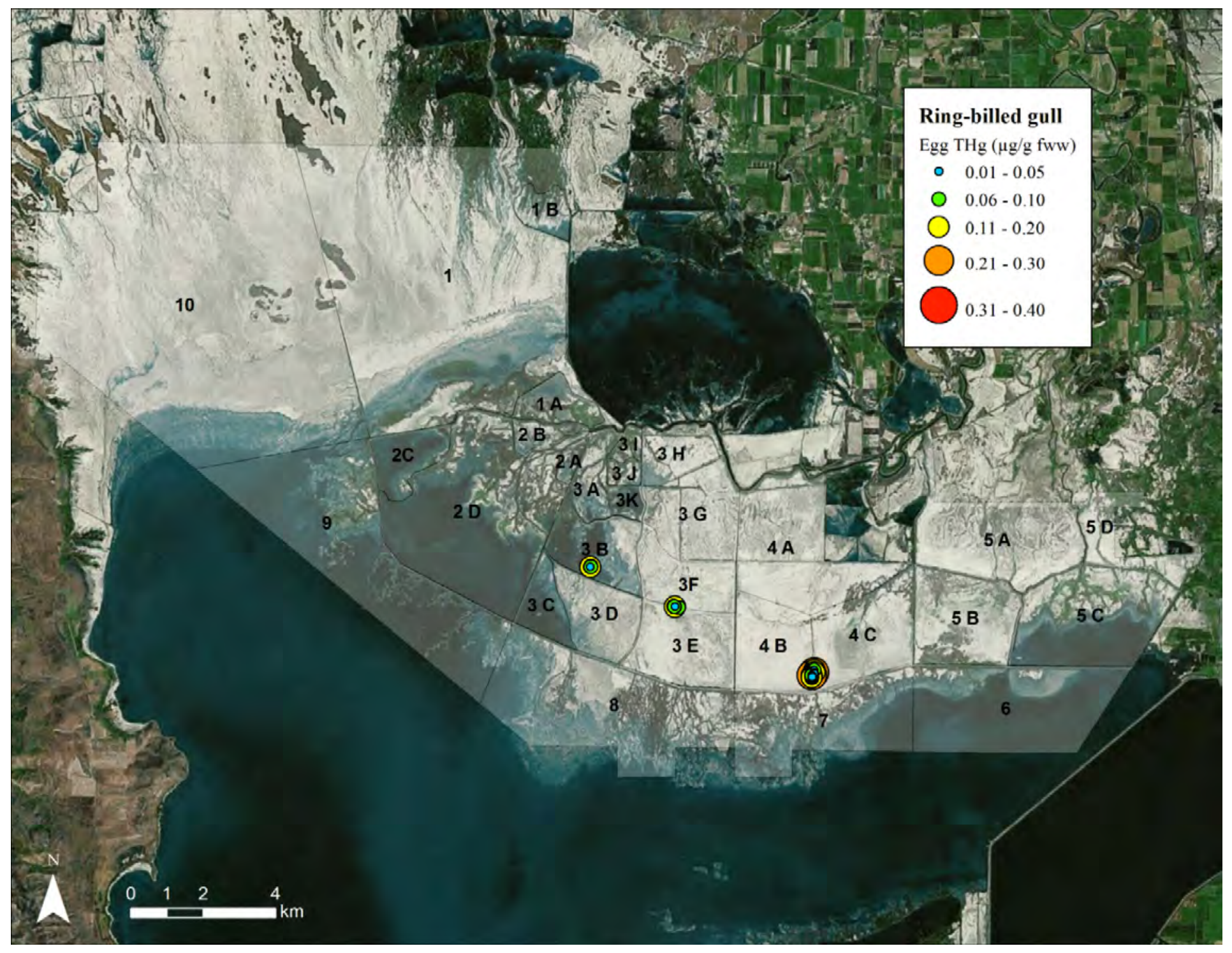

Figure A-33. Total mercury concentrations ( $\mathrm{THg} ; \mu \mathrm{g} / \mathrm{g}$ fww) in eggs of ring-billed gulls breeding at Bear River Migratory Bird Refuge in Great Salt Lake, Utah, 2010-2012. 


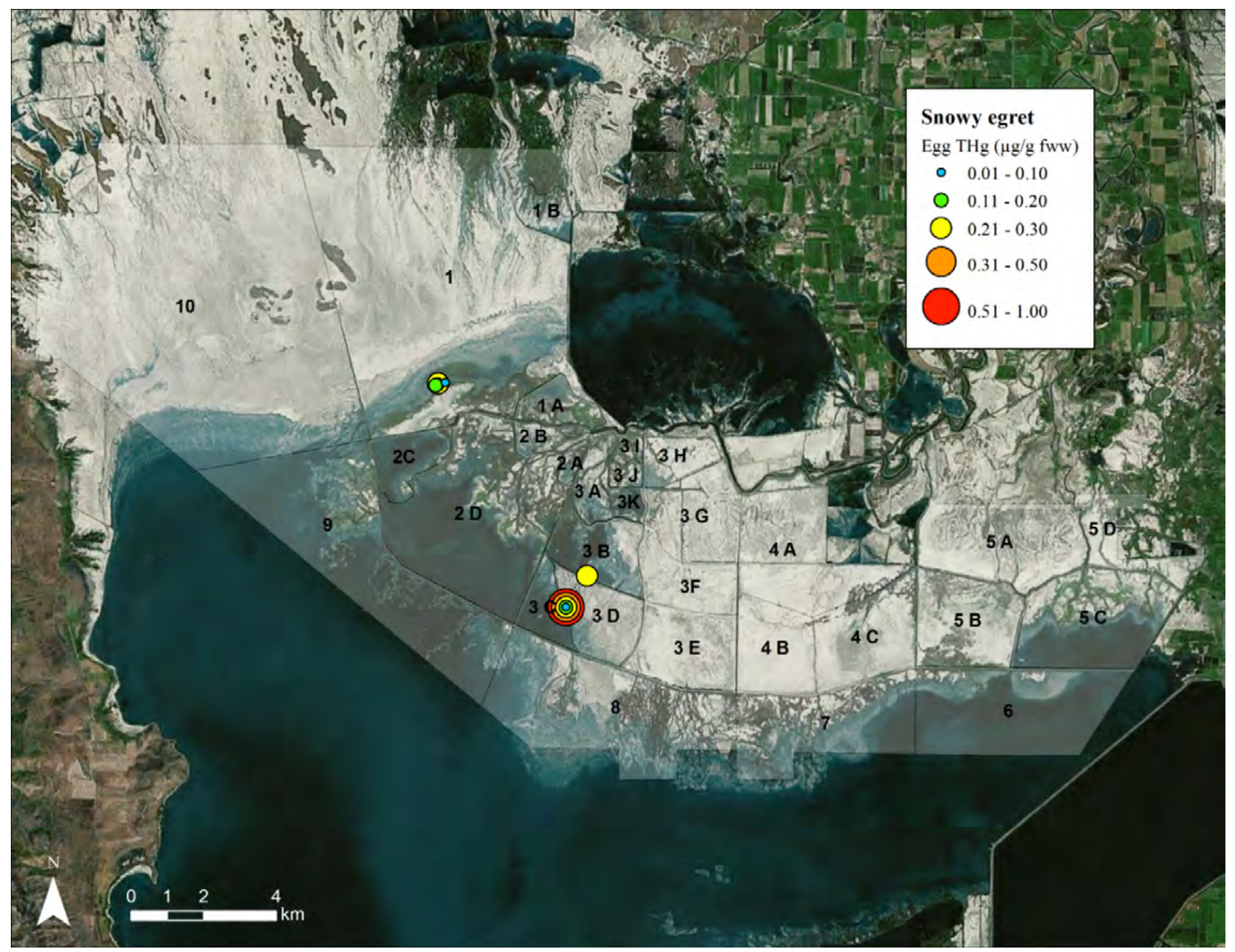

Figure A-34. Total mercury concentrations (THg; $\mu \mathrm{g} / \mathrm{g} \mathrm{fww}$ ) in eggs of snowy egrets breeding at Bear River Migratory Bird Refuge in Great Salt Lake, Utah, 2010-2012. 


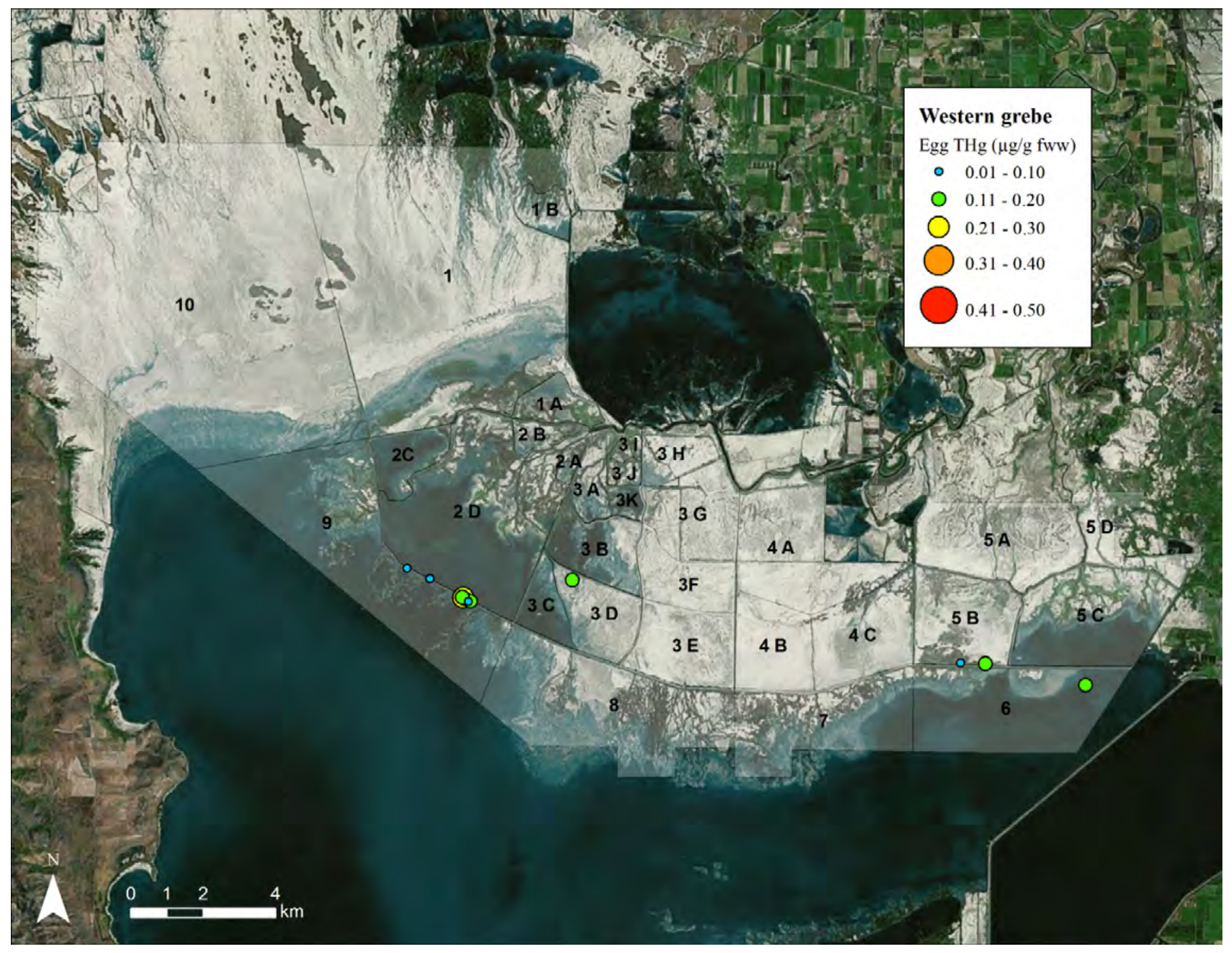

Figure A-35. Total mercury concentrations ( $\mathrm{THg} ; \mu \mathrm{g} / \mathrm{g} \mathrm{fww}$ ) in eggs of western grebes breeding at Bear River Migratory Bird Refuge in Great Salt Lake, Utah, 2010-2012. 


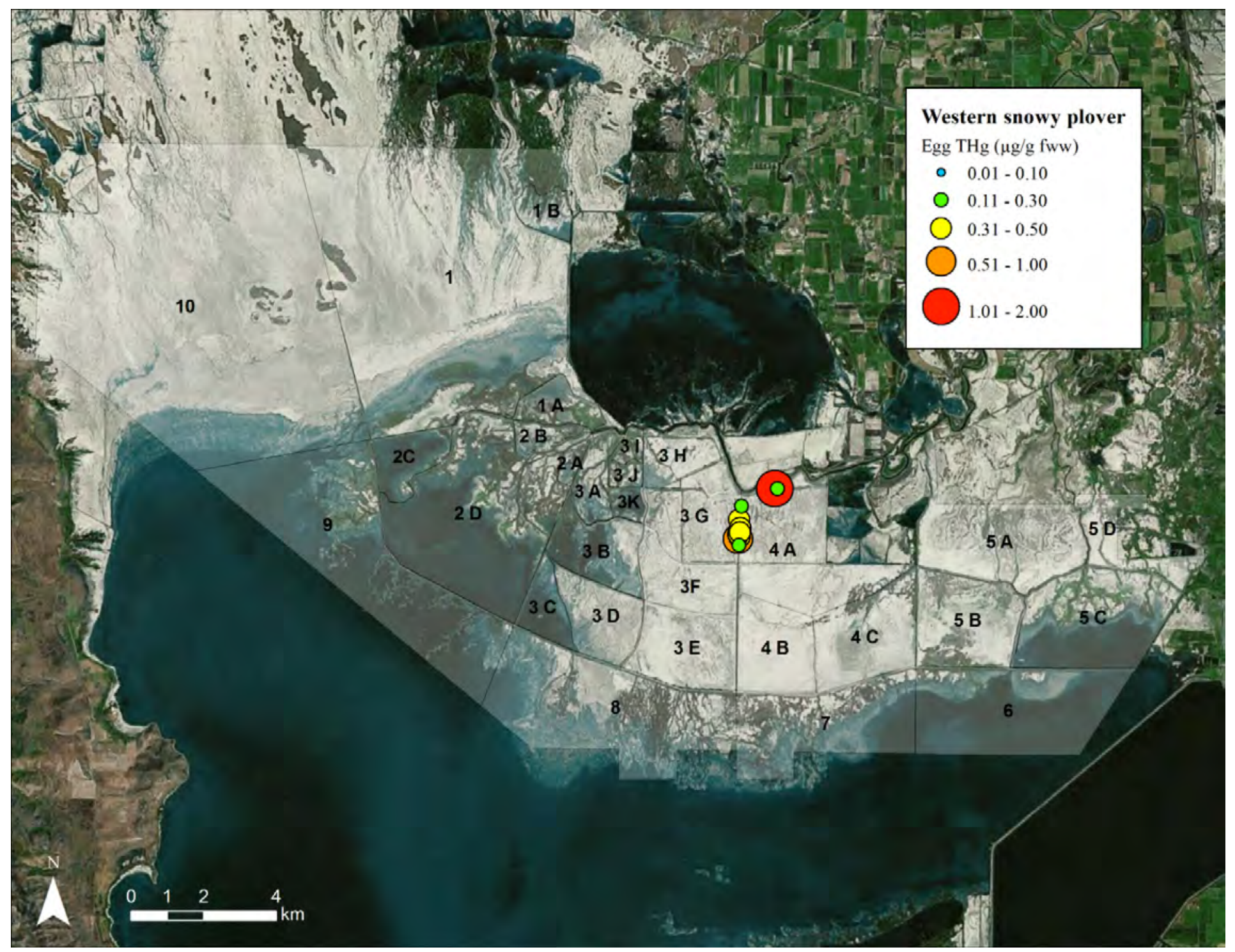

Figure A-36. Total mercury concentrations ( $\mathrm{THg} ; \mu \mathrm{g} / \mathrm{g}$ fww) in eggs of snowy plovers breeding at Bear River Migratory Bird Refuge in Great Salt Lake, Utah, 2010-2012. 


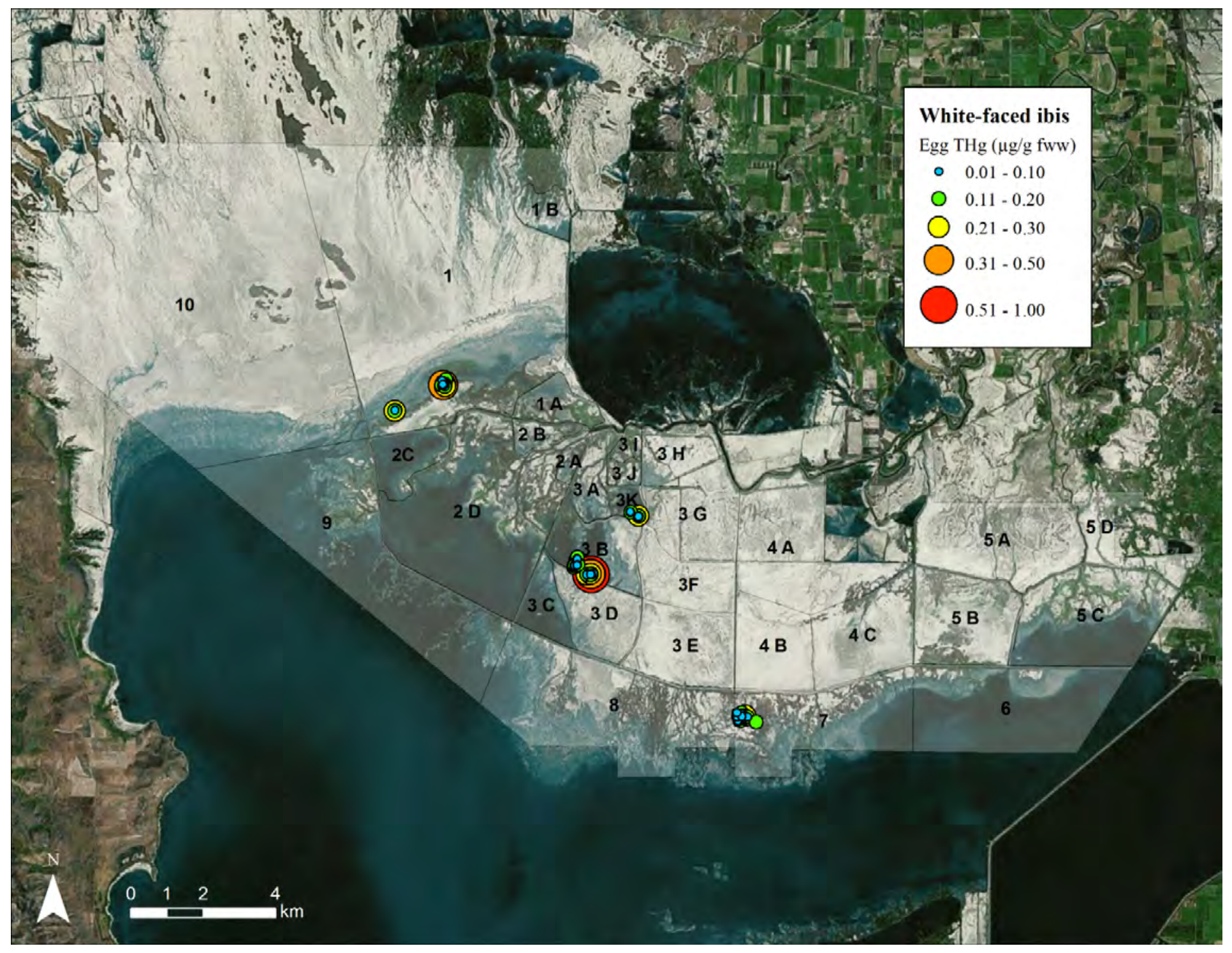

Figure A-37. Total mercury concentrations (THg; $\mu \mathrm{g} / \mathrm{g} \mathrm{fww}$ ) in eggs of white-faced ibis breeding at Bear River Migratory Bird Refuge in Great Salt Lake, Utah, 2010-2012. 


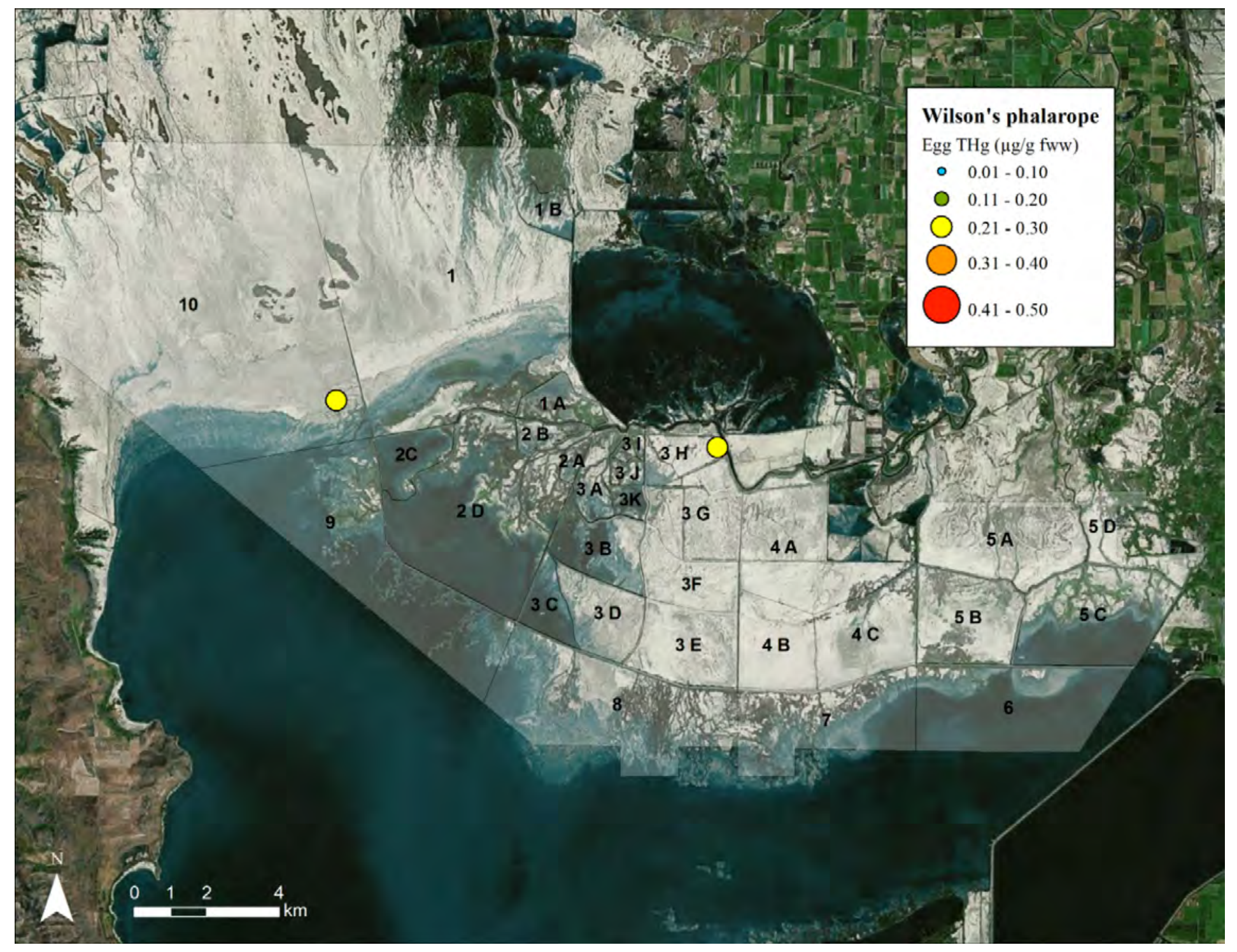

Figure A-38. Total mercury concentrations (THg; $\mu \mathrm{g} / \mathrm{g}$ fww) in eggs of Wilson's phalaropes breeding at Bear River Migratory Bird Refuge in Great Salt Lake, Utah, 2010-2012. 


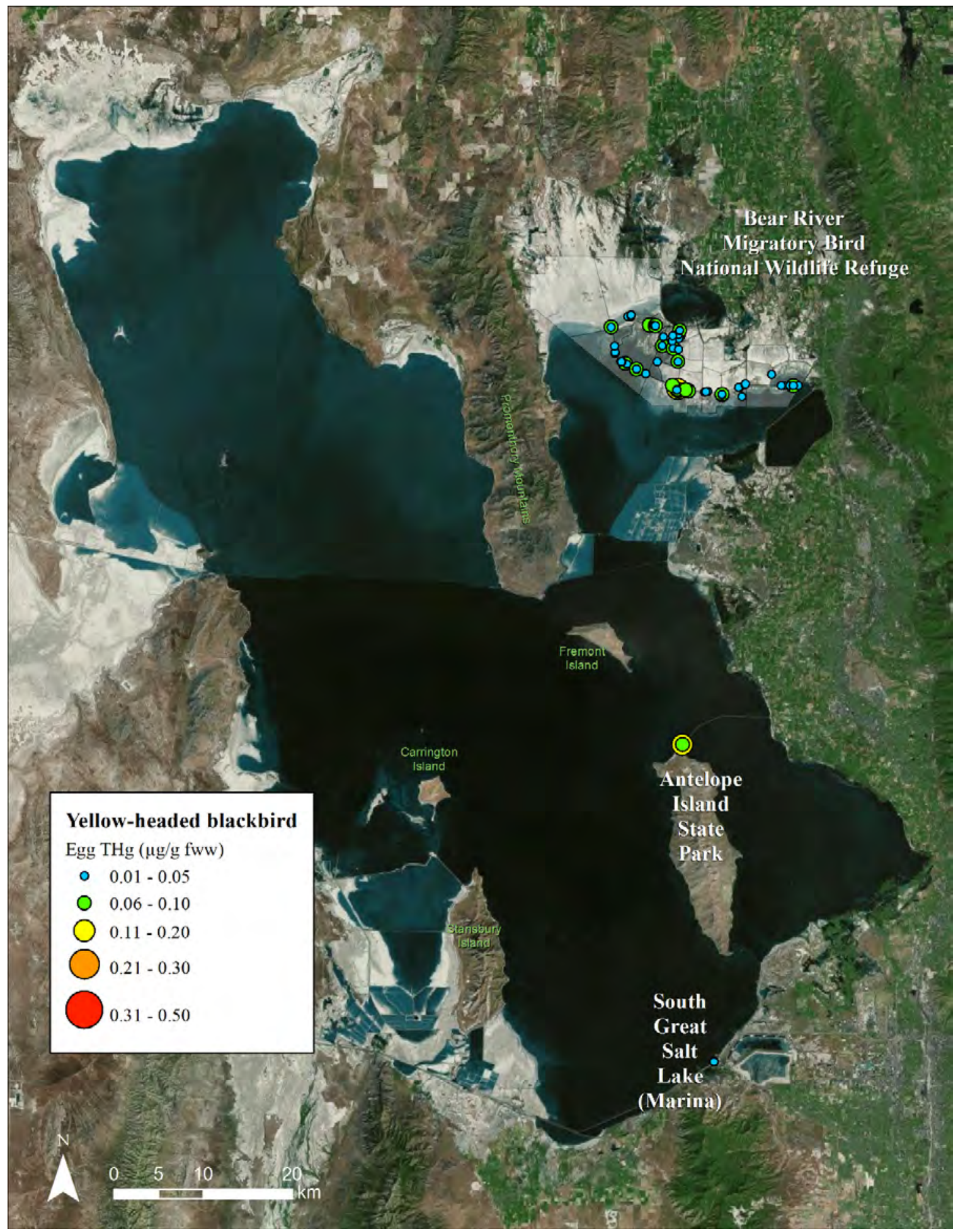

Figure A-39. Total mercury concentrations (THg; $\mu \mathrm{g} / \mathrm{g} \mathrm{fww}$ ) in eggs of yellow-headed blackbirds breeding in Great Salt Lake, Utah, 2010-2012. 


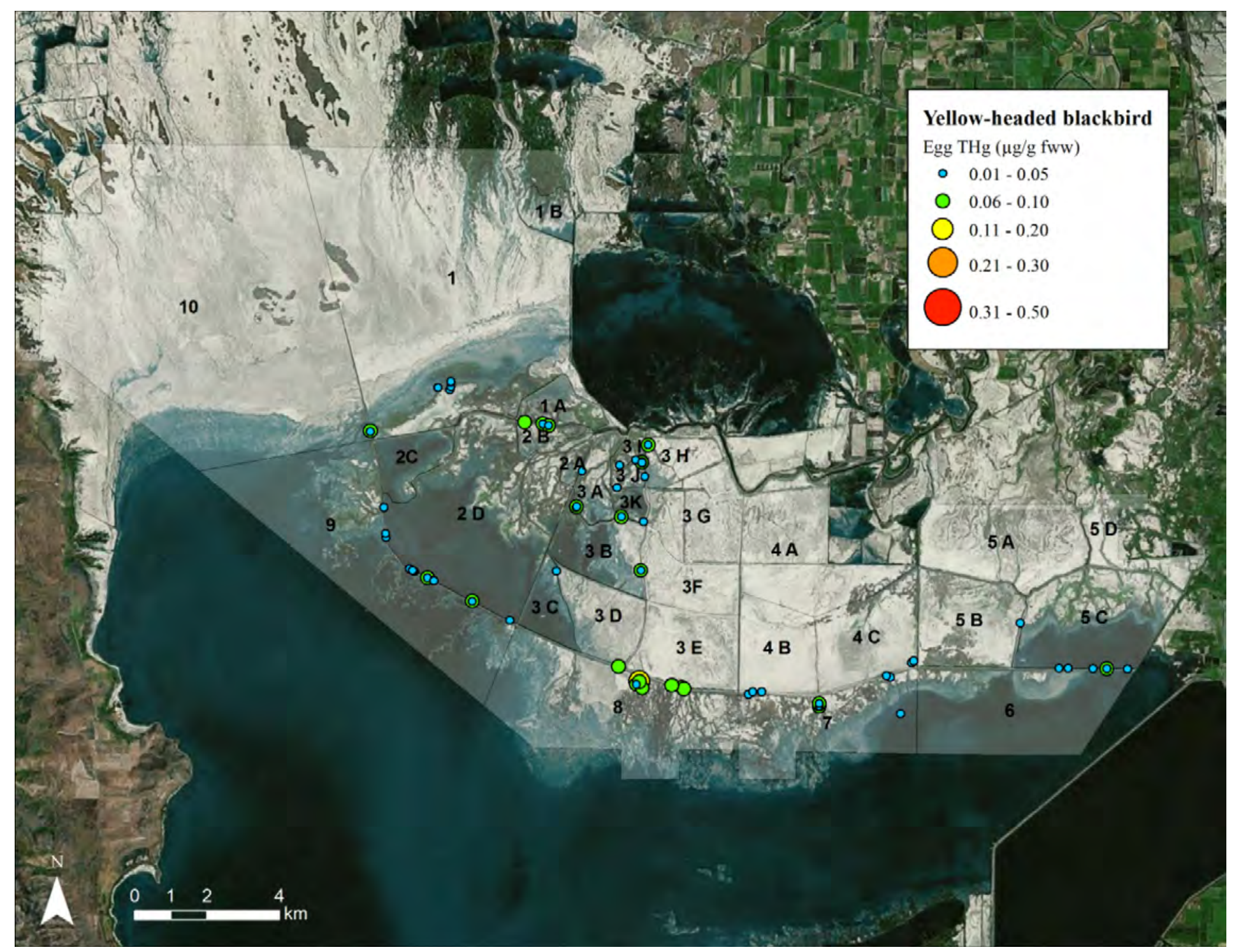

Figure A-40. Total mercury concentrations (THg; $\mu \mathrm{g} / \mathrm{g} \mathrm{fww}$ ) in eggs of yellow-headed blackbirds breeding at Bear River Migratory Bird Refuge in Great Salt Lake, Utah, 2010-2012. 
Appendix B. Hot spot maps displaying total mercury concentrations ( $\mathrm{THg} ; \mu \mathrm{g} / \mathrm{g}$ fww) in eggs of 11 species of birds breeding in Great Salt Lake, Utah, 2010-2012. Species are displayed alphabetically. 


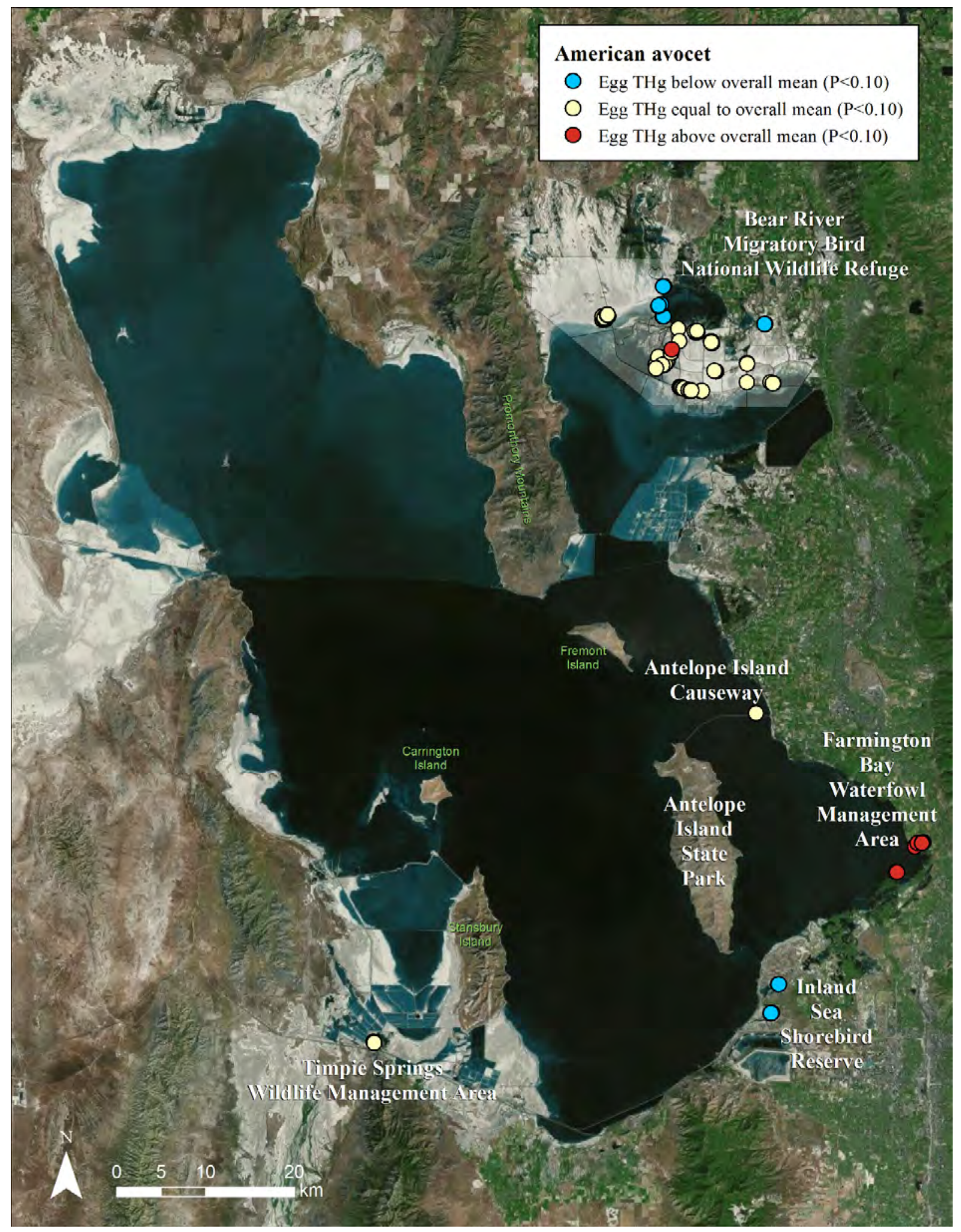

Figure B-1. Hot spot map depicting mercury concentrations (THg; $\mu \mathrm{g} / \mathrm{g}$ fww) in eggs of American avocets breeding in Great Salt Lake, Utah, 2010-2012. Egg mercury concentrations significantly below the mean are colored in blue and egg mercury concentrations significantly above the mean are colored in red. Egg mercury concentrations similar to the overall mean are colored in yellow. 


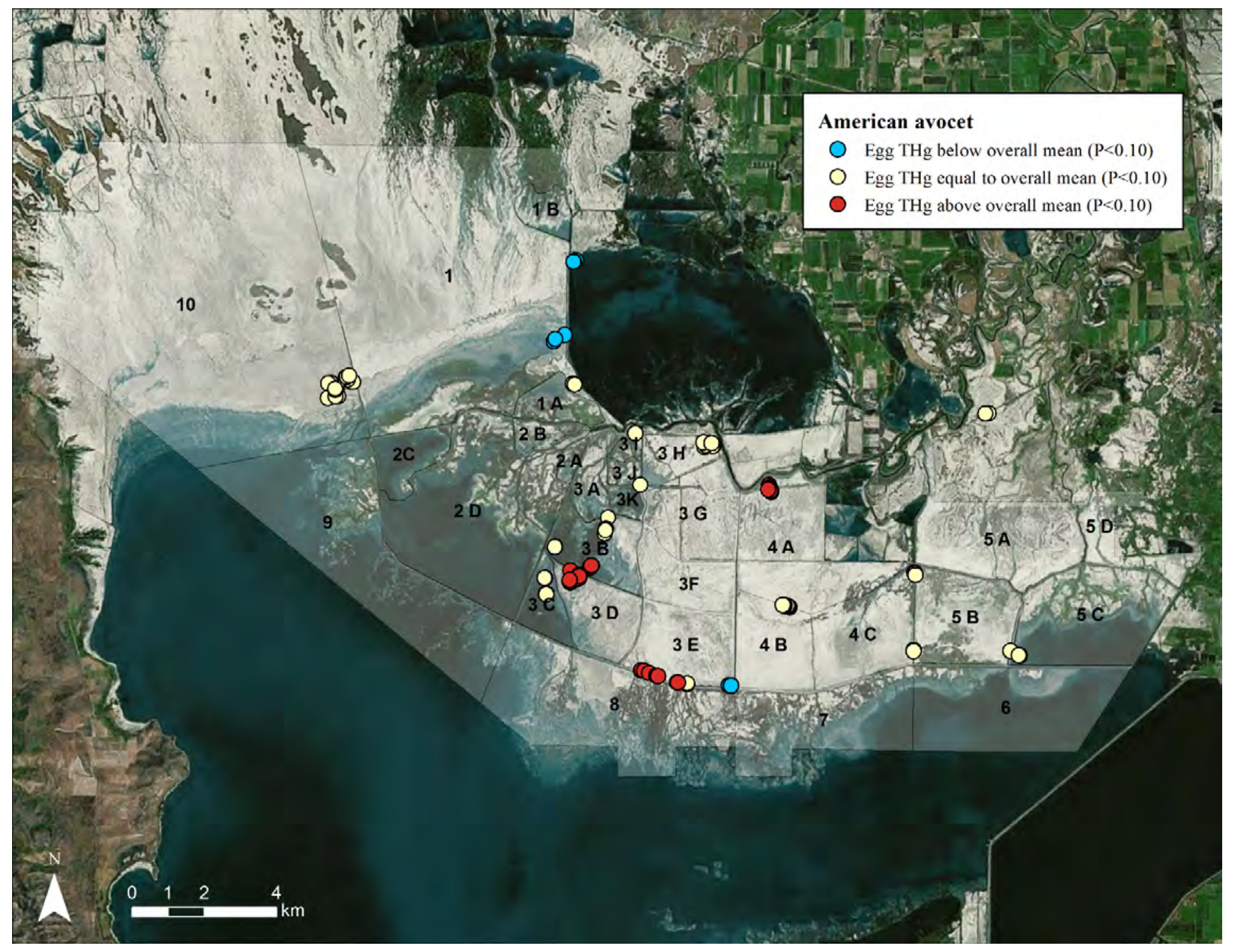

Figure B-2. Hot spot map depicting mercury concentrations (THg; $\mu \mathrm{g} / \mathrm{g} \mathrm{fww}$ ) in eggs of American avocets breeding at Bear River Migratory Bird Refuge in Great Salt Lake, Utah, 2010-2012. Egg mercury concentrations significantly below the mean are colored in blue and egg mercury concentrations significantly above the mean are colored in red. Egg mercury concentrations similar to the overall mean are colored in yellow. 


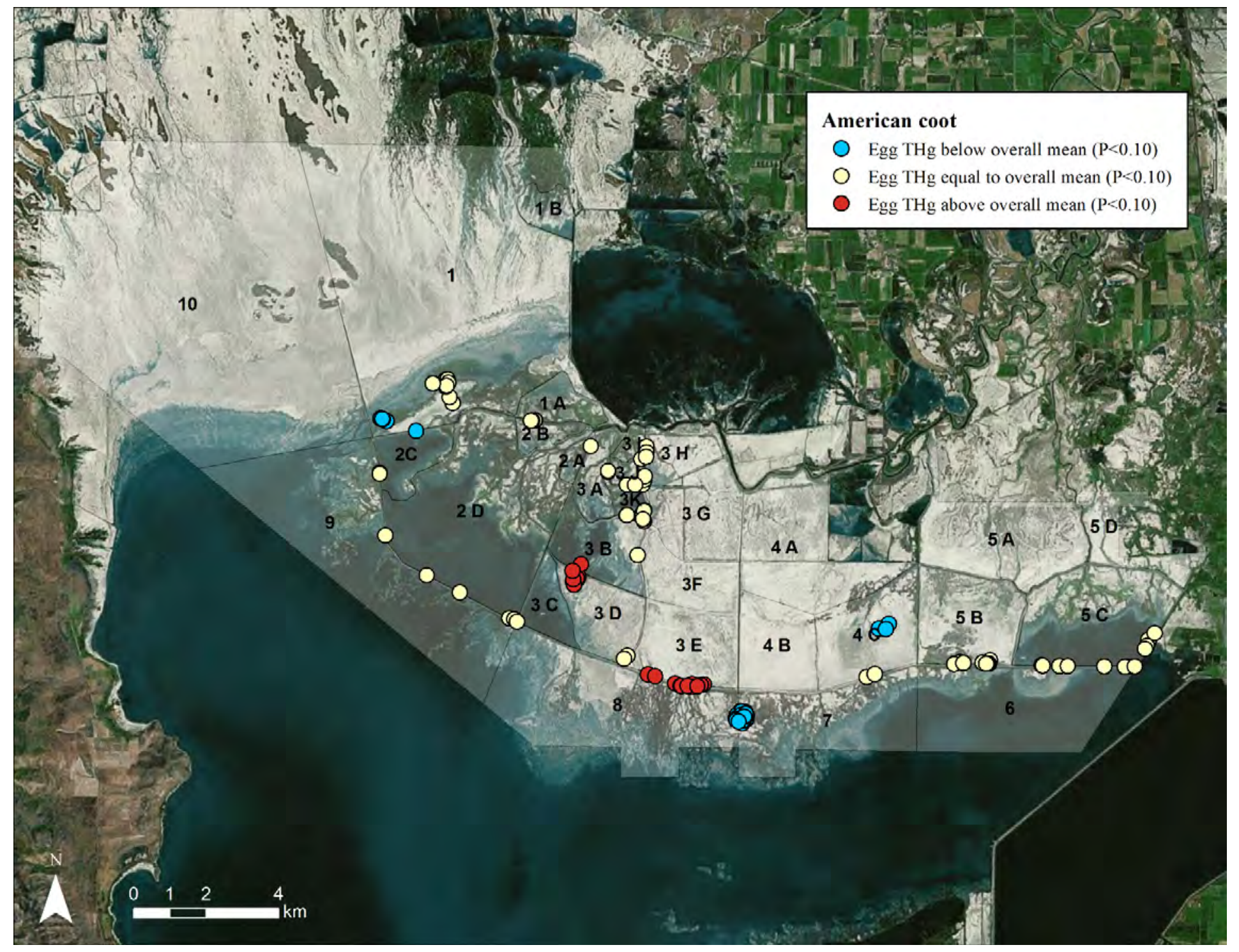

Figure B-3. Hot spot map depicting mercury concentrations (THg; $\mu \mathrm{g} / \mathrm{g} \mathrm{fww)}$ ) in eggs of American coots breeding at Bear River Migratory Bird Refuge in Great Salt Lake, Utah, 2010-2012. Egg mercury concentrations significantly below the mean are colored in blue and egg mercury concentrations significantly above the mean are colored in red. Egg mercury concentrations similar to the overall mean are colored in yellow. 


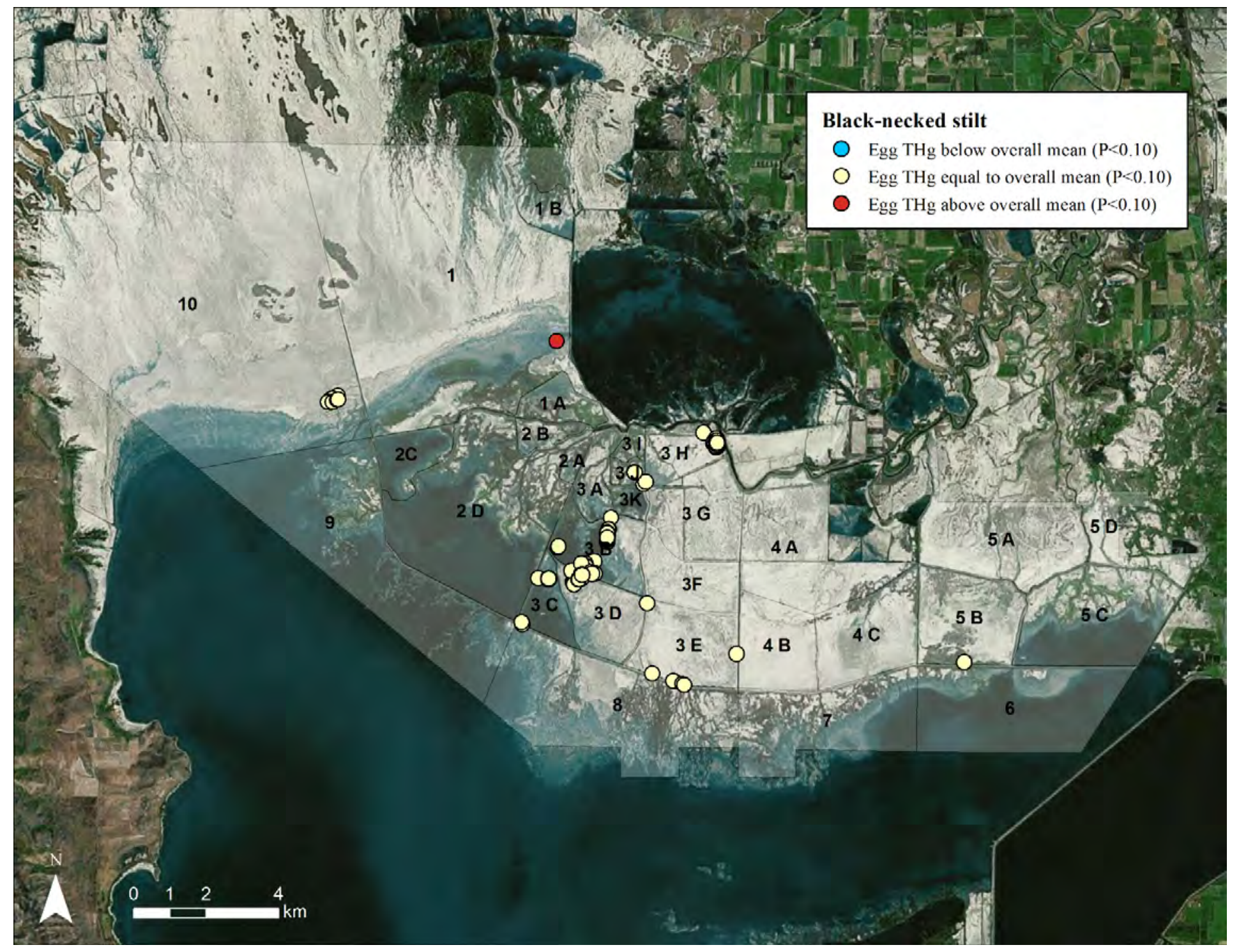

Figure B-4. Hot spot map depicting mercury concentrations (THg; $\mu \mathrm{g} / \mathrm{g}$ fww) in eggs of black-necked stilts breeding at Bear River Migratory Bird Refuge in Great Salt Lake, Utah, 2010-2012. Egg mercury concentrations significantly below the mean are colored in blue and egg mercury concentrations significantly above the mean are colored in red. Egg mercury concentrations similar to the overall mean are colored in yellow. 


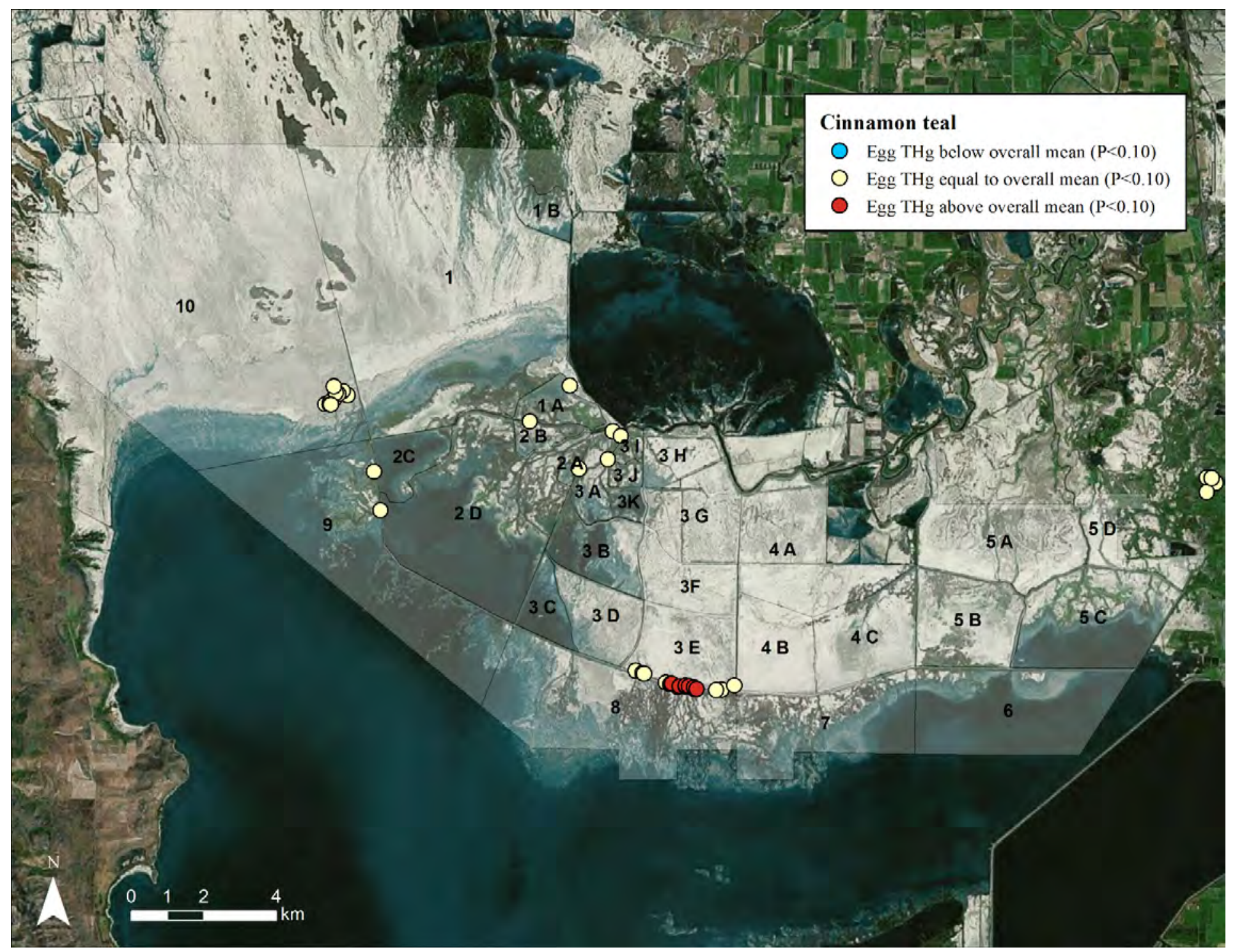

Figure B-5. Hot spot map depicting mercury concentrations (THg; $\mu \mathrm{g} / \mathrm{g} \mathrm{fww}$ ) in eggs of cinnamon teal breeding at Bear River Migratory Bird Refuge in Great Salt Lake, Utah 2010-2012. Egg mercury concentrations significantly below the mean are colored in blue and egg mercury concentrations significantly above the mean are colored in red. Egg mercury concentrations similar to the overall mean are colored in yellow. 


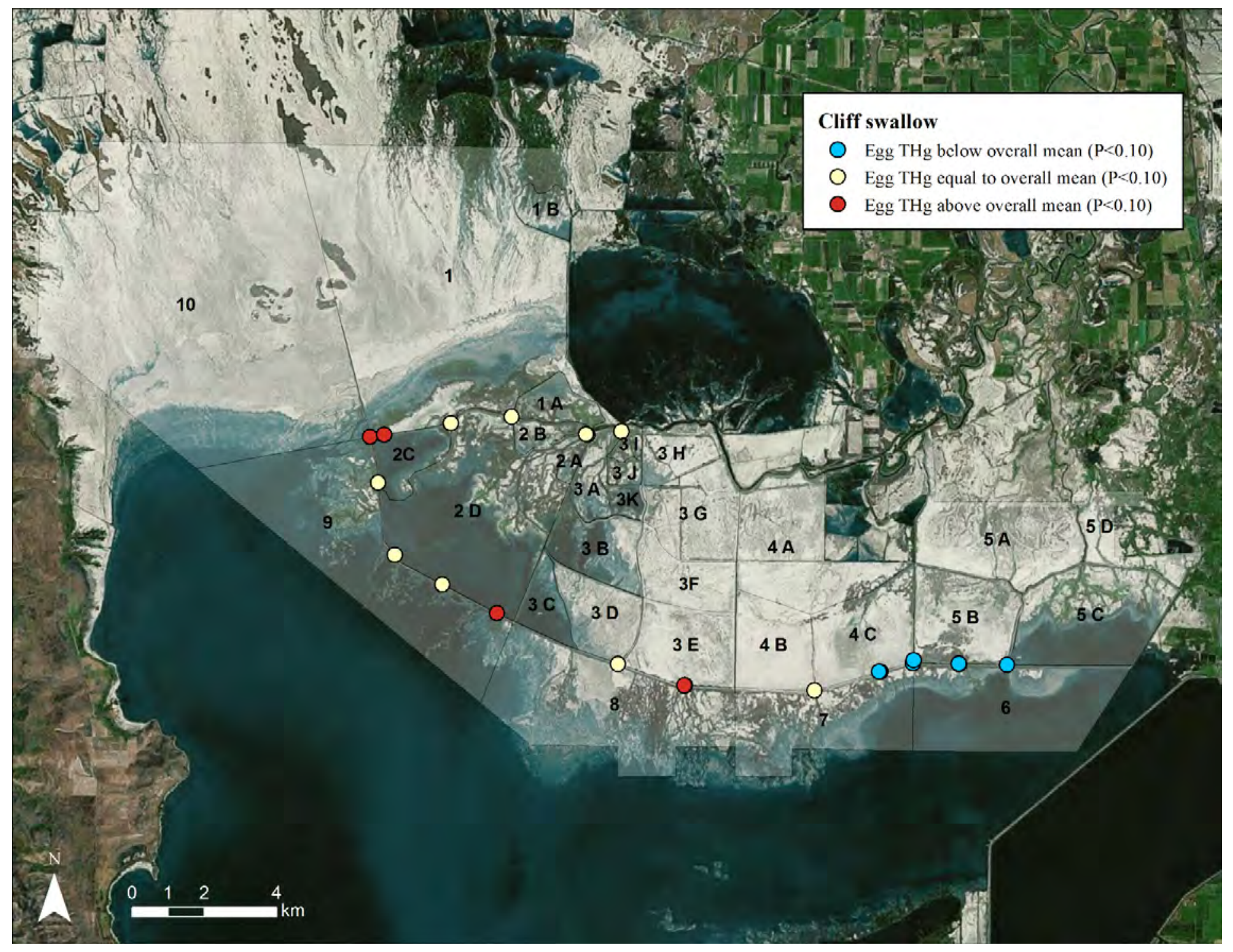

Figure B-6. Hot spot map depicting mercury concentrations (THg; $\mu \mathrm{g} / \mathrm{g} \mathrm{fww}$ ) in eggs of cliff swallows breeding at Bear River Migratory Bird Refuge in Great Salt Lake, Utah, 2010-2012. Egg mercury concentrations significantly below the mean are colored in blue and egg mercury concentrations significantly above the mean are colored in red. Egg mercury concentrations similar to the overall mean are colored in yellow. 


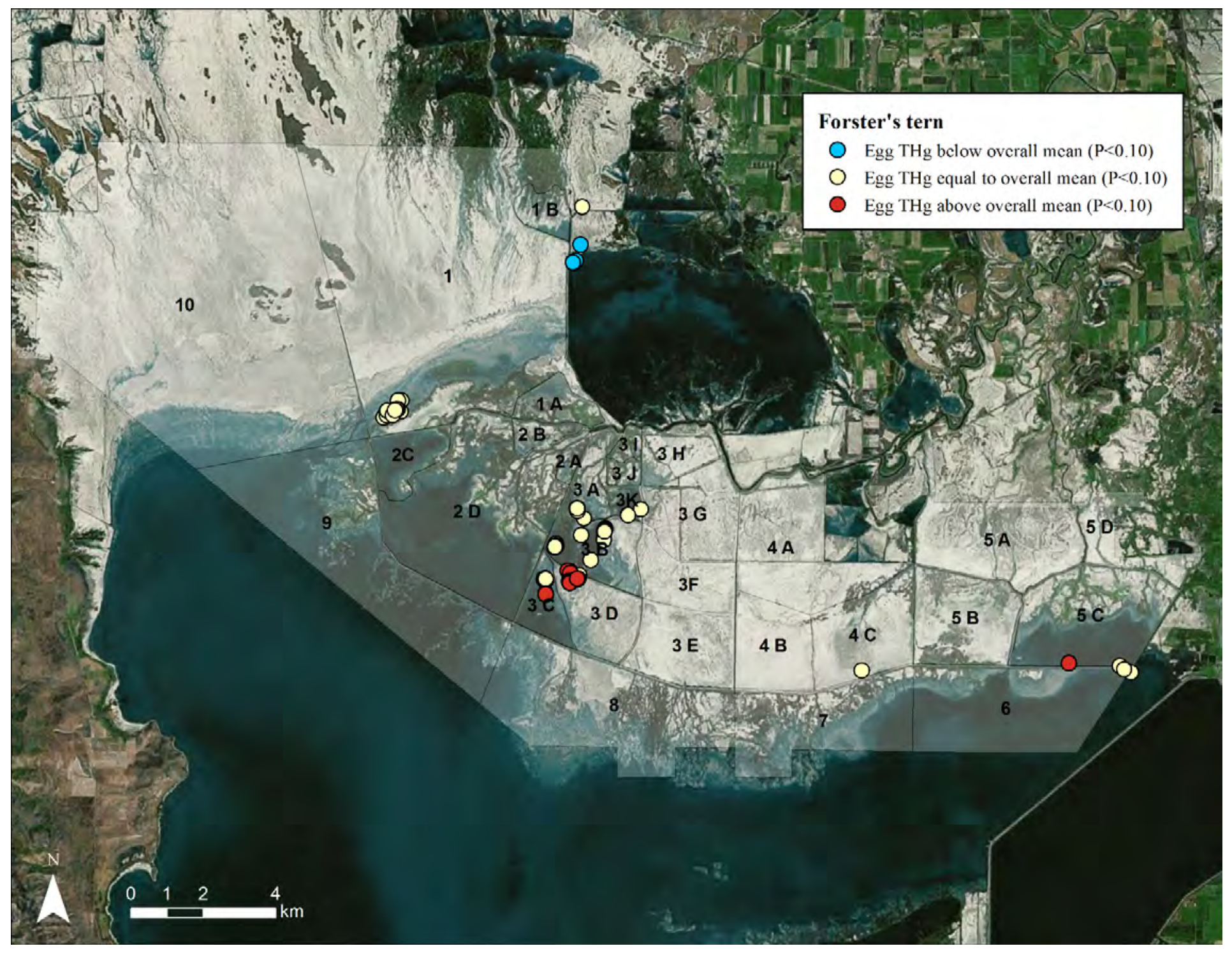

Figure B-7. Hot spot map depicting mercury concentrations (THg; $\mu \mathrm{g} / \mathrm{g} \mathrm{fww)}$ in eggs of Forster's terns breeding at Bear River Migratory Bird Refuge in Great Salt Lake, Utah, 2010-2012. Egg mercury concentrations significantly below the mean are colored in blue and egg mercury concentrations significantly above the mean are colored in red. Egg mercury concentrations similar to the overall mean are colored in yellow. 


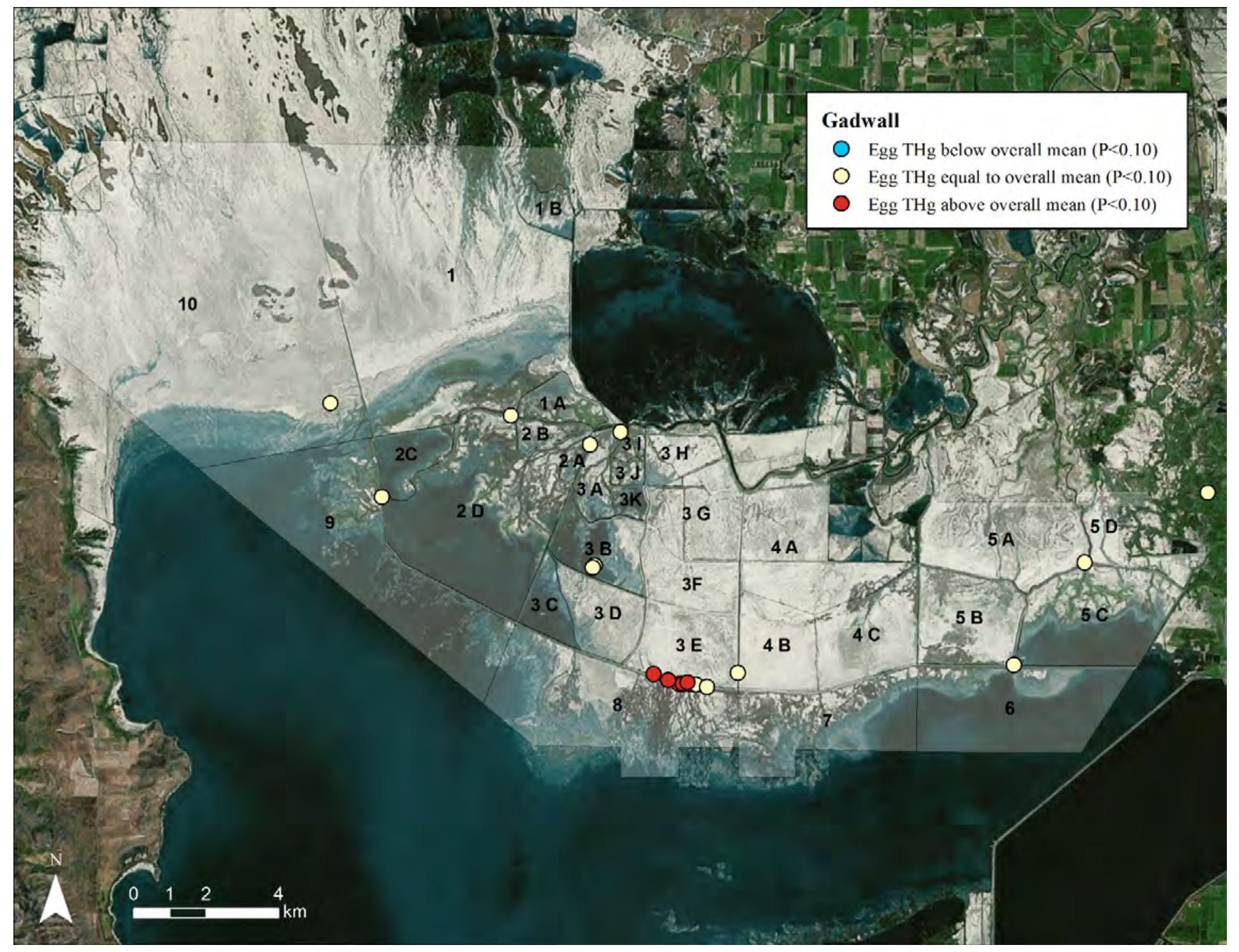

Figure B-8. Hot spot map depicting mercury concentrations (THg; $\mu \mathrm{g} / \mathrm{g} \mathrm{fww}$ ) in eggs of gadwall breeding at Bear River Migratory Bird Refuge in Great Salt Lake, Utah, 2010 2012. Egg mercury concentrations significantly below the mean are colored in blue and egg mercury concentrations significantly above the mean are colored in red. Egg mercury concentrations similar to the overall mean are colored in yellow. 


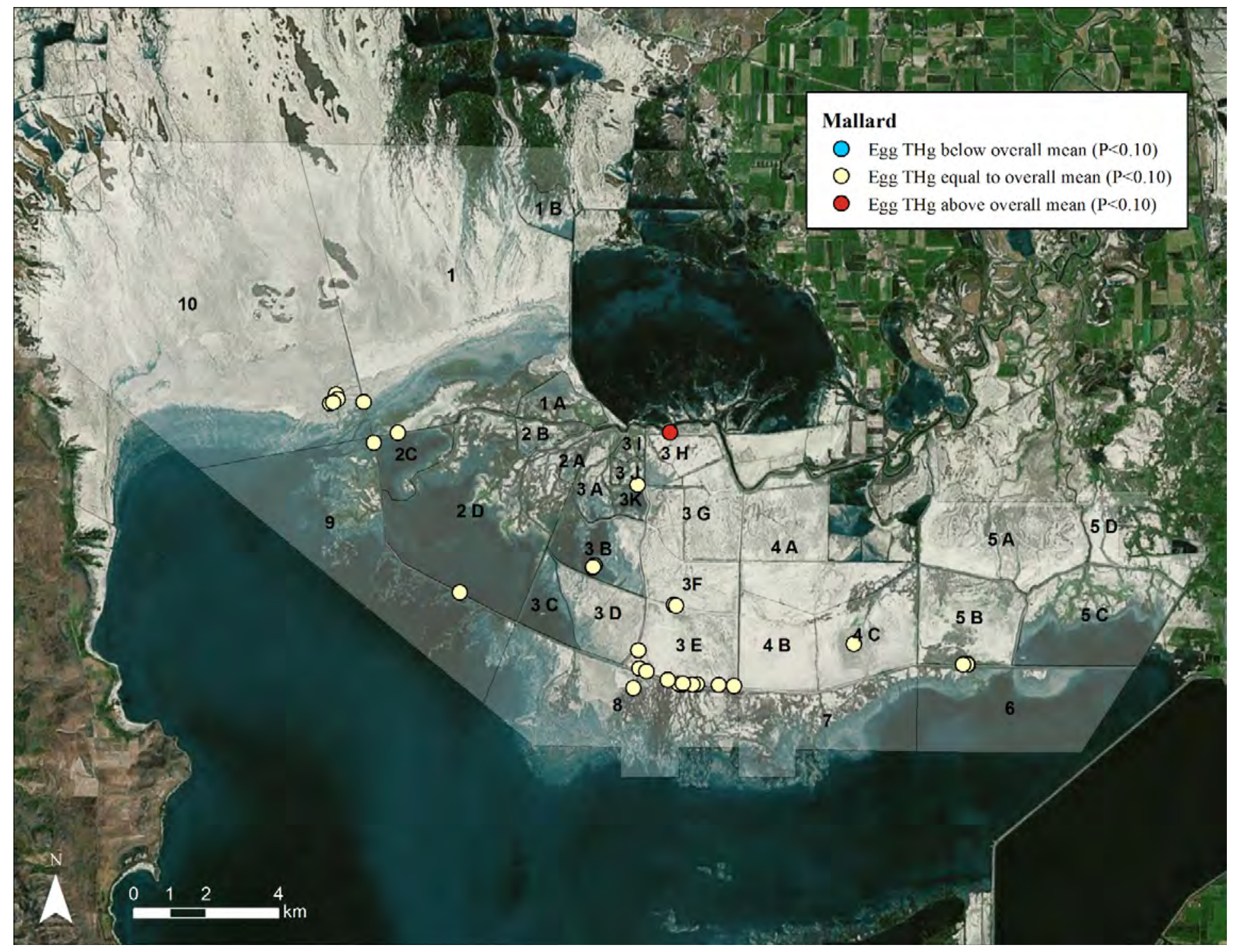

Figure B-9. Hot spot map depicting mercury concentrations (THg; $\mu \mathrm{g} / \mathrm{g} \mathrm{fww}$ ) in eggs of mallard breeding at Bear River Migratory Bird Refuge in Great Salt Lake, Utah, 2010 2012. Egg mercury concentrations significantly below the mean are colored in blue and egg mercury concentrations significantly above the mean are colored in red. Egg mercury concentrations similar to the overall mean are colored in yellow. 


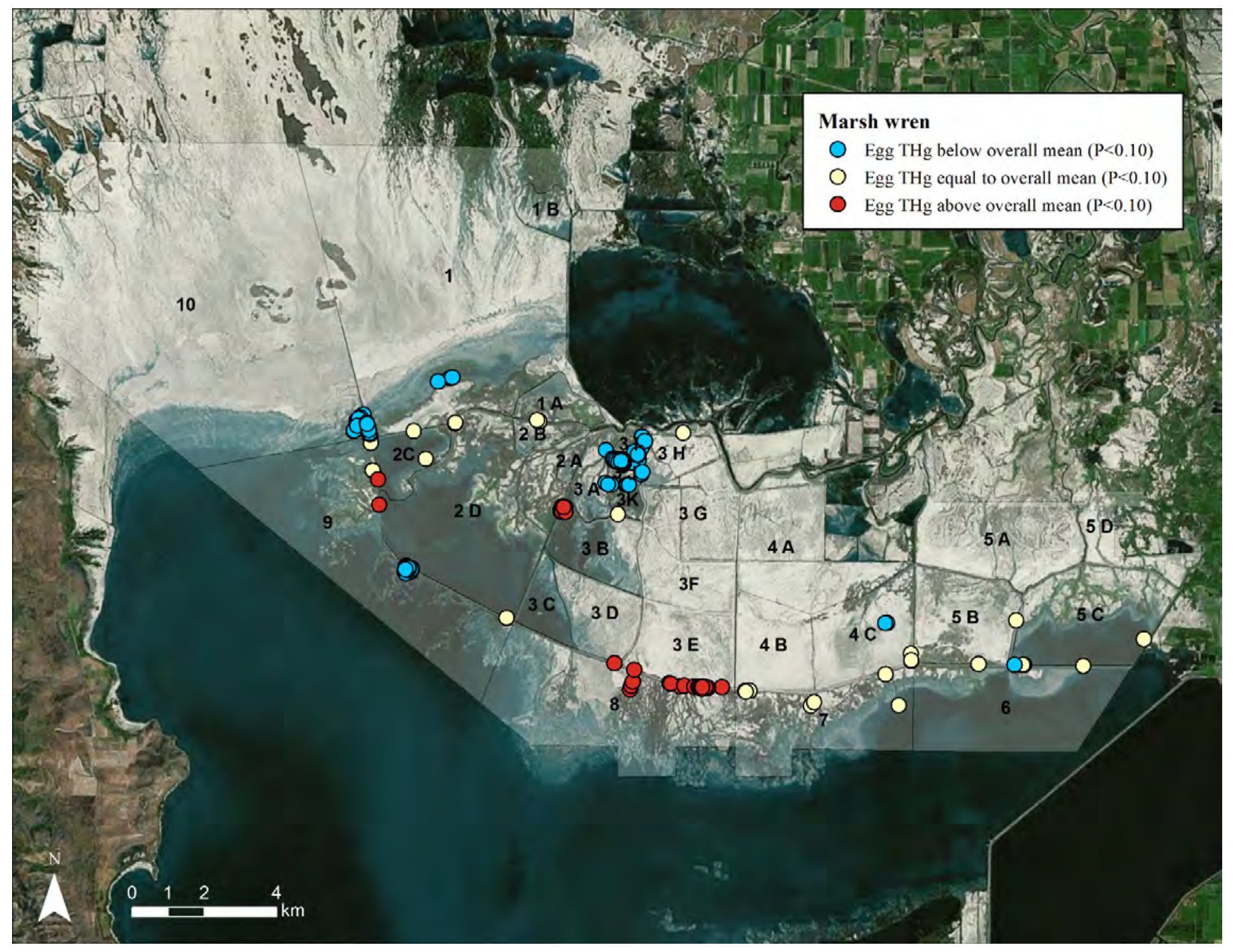

Figure B-10. Hot spot map depicting mercury concentrations ( $\mathrm{THg} ; \mu \mathrm{g} / \mathrm{g} \mathrm{fww}$ ) in eggs of marsh wrens breeding at Bear River Migratory Bird Refuge in Great Salt Lake, Utah, 2010-2012. Egg mercury concentrations significantly below the mean are colored in blue and egg mercury concentrations significantly above the mean are colored in red. Egg mercury concentrations similar to the overall mean are colored in yellow. 


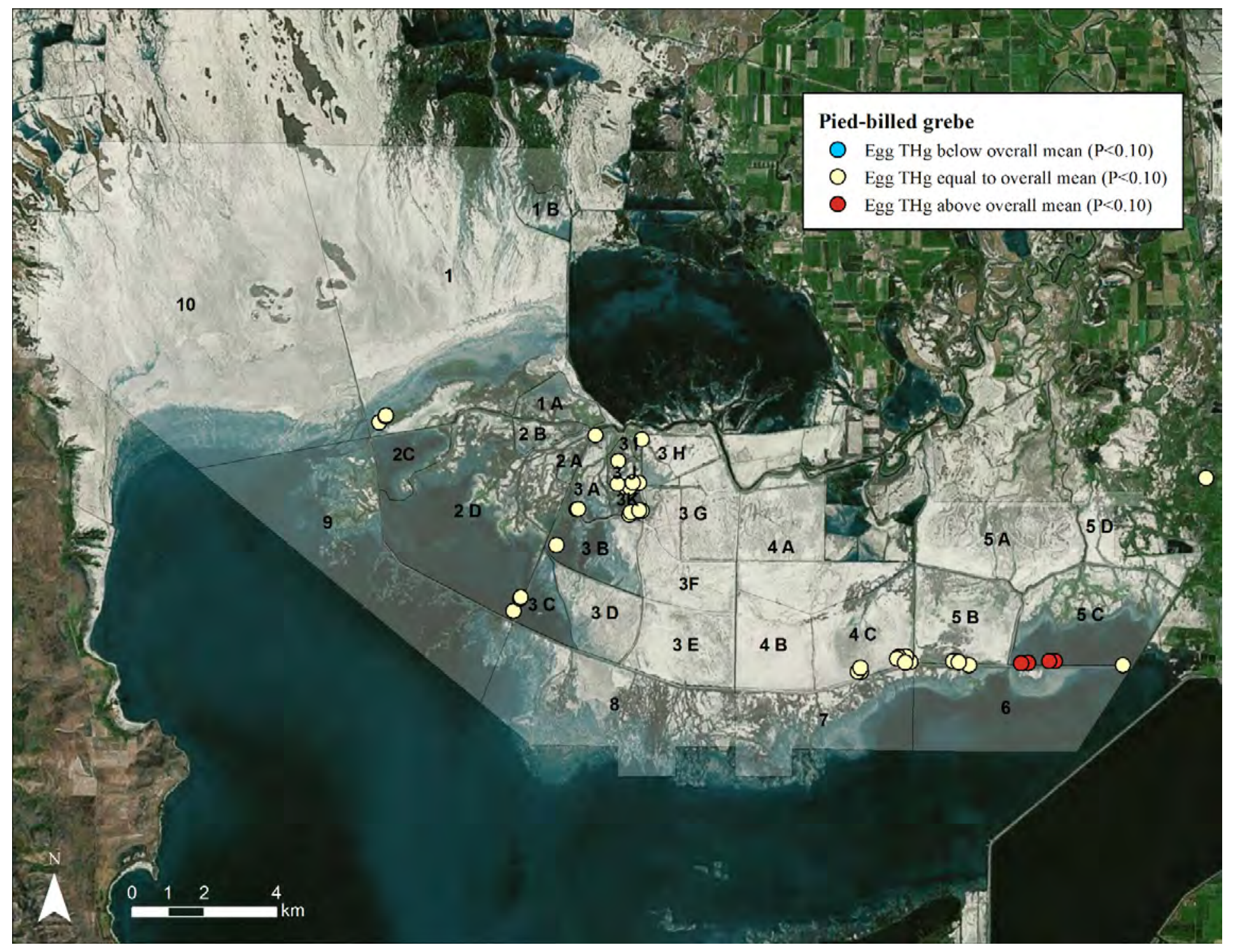

Figure B-11. Hot spot map depicting mercury concentrations (THg; $\mu \mathrm{g} / \mathrm{g} \mathrm{fww}$ ) in eggs of pied-billed grebes breeding at Bear River Migratory Bird Refuge in Great Salt Lake, Utah, 2010-2012. Egg mercury concentrations significantly below the mean are colored in blue and egg mercury concentrations significantly above the mean are colored in red. Egg mercury concentrations similar to the overall mean are colored in yellow. 


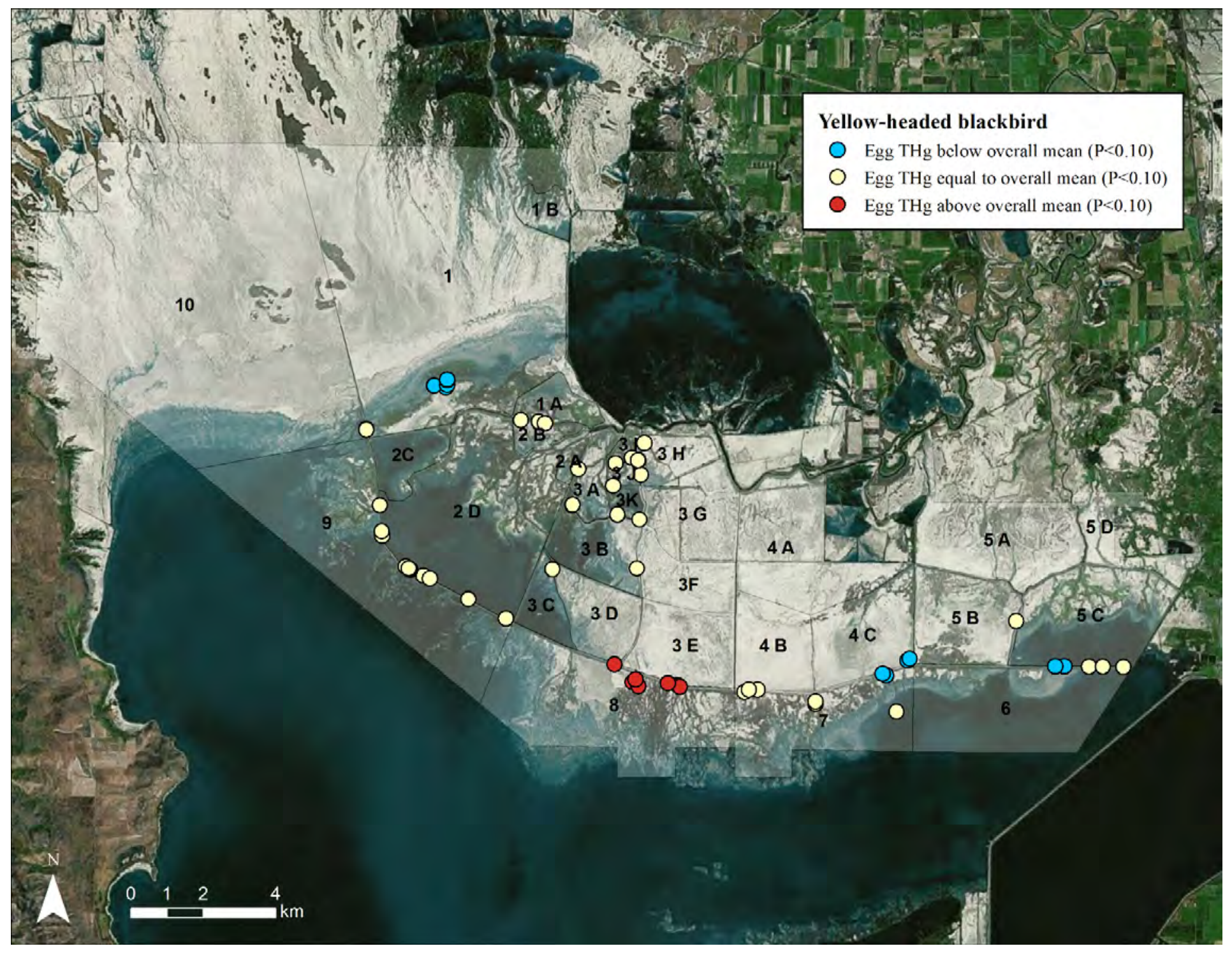

Figure B-12. Hot spot map depicting mercury concentrations ( $\mathrm{THg} ; \mu \mathrm{g} / \mathrm{g} \mathrm{fww}$ ) in eggs of yellow-headed blackbirds breeding at Bear River Migratory Bird Refuge in Great Salt Lake, Utah, 2010-2012. Egg mercury concentrations significantly below the mean are colored in blue and egg mercury concentrations significantly above the mean are colored in red. Egg mercury concentrations similar to the overall mean are colored in yellow. 
This page left intentionally blank 
Appendix C. Maps displaying selenium concentrations (Se; $\mu g / g$ fww) in eggs of 32 species of birds breeding in Great Salt Lake, Utah, 2010-2011. Species are displayed alphabetically. 


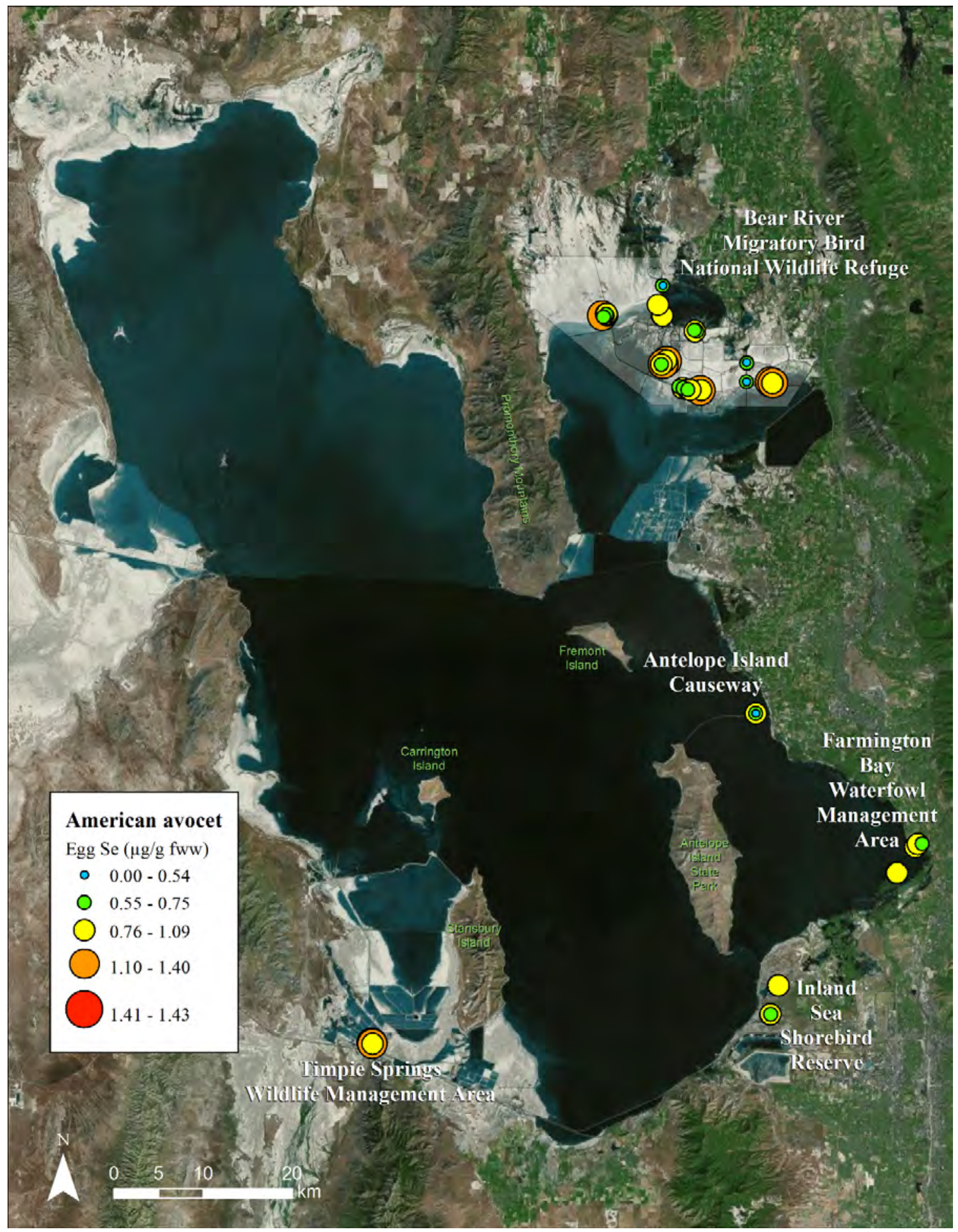

Figure C-1. Selenium concentrations (Se; $\mu \mathrm{g} / \mathrm{g}$ fww) in eggs of American avocets breeding in Great Salt Lake, Utah, 2010-2012. 


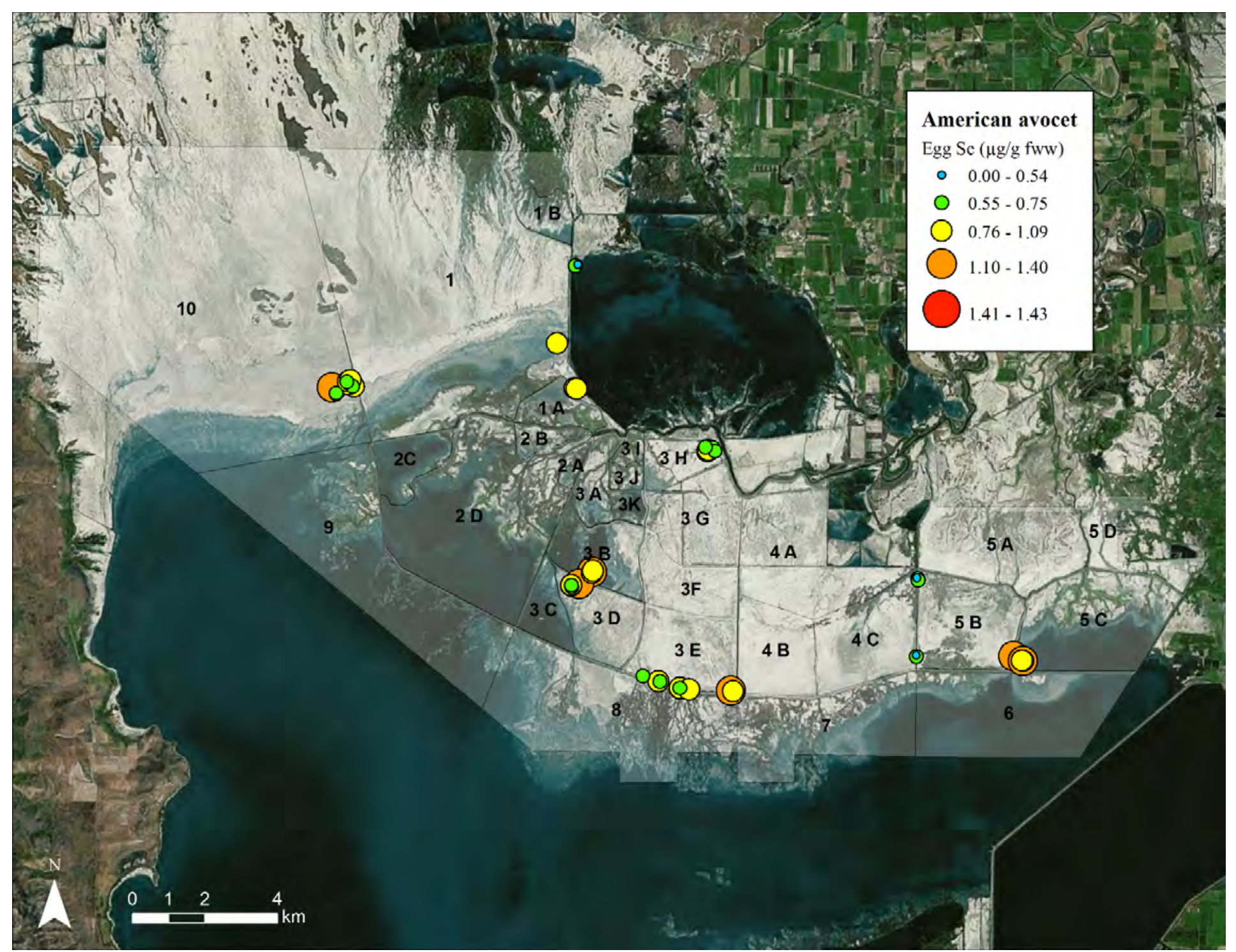

Figure C-2. Selenium concentrations (Se; $\mu \mathrm{g} / \mathrm{g}$ fww) in eggs of American avocets breeding at Bear River Migratory Bird Refuge in Great Salt Lake, Utah, $2010-2012$. 


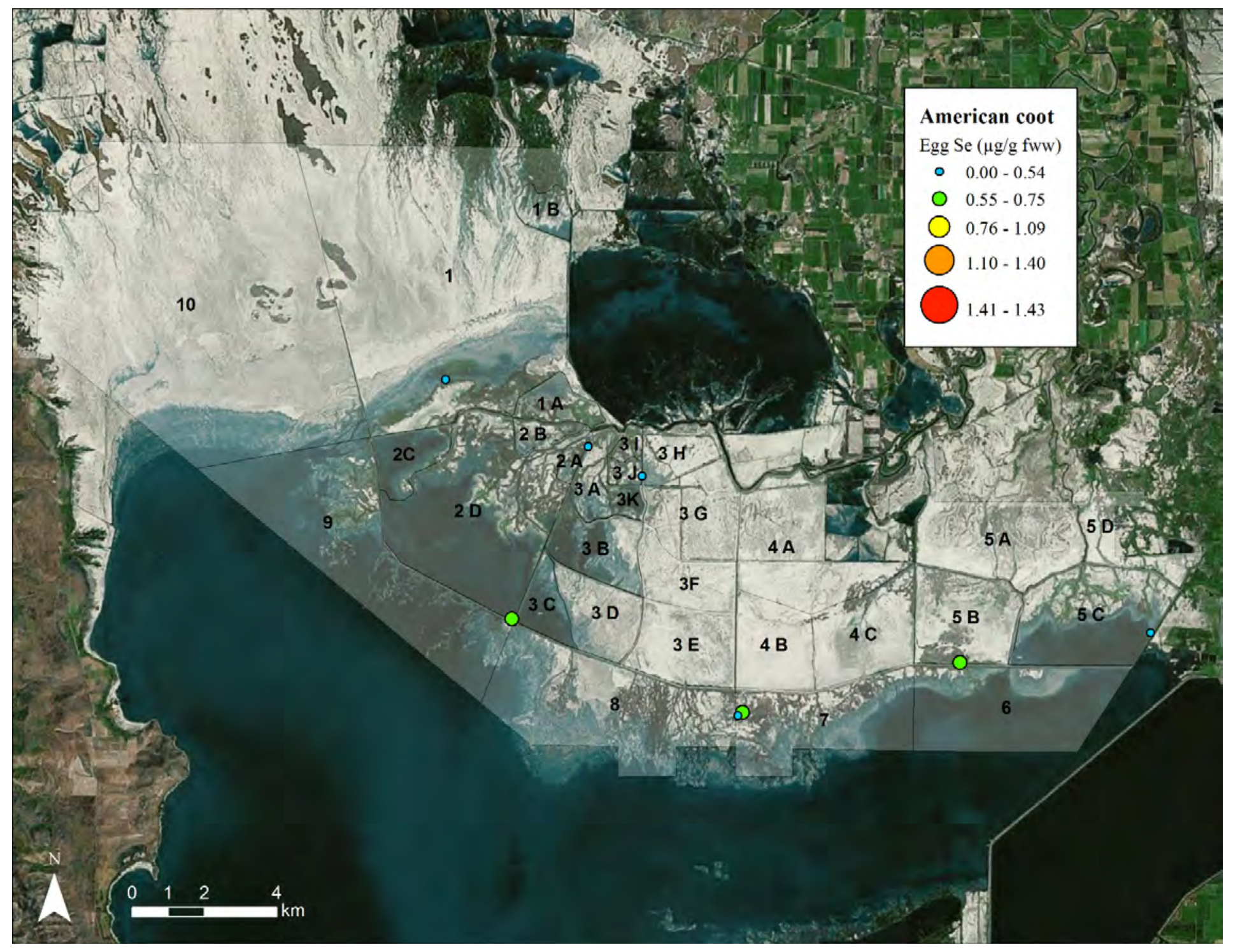

Figure C-3. Selenium concentrations (Se; $\mu \mathrm{g} / \mathrm{g} \mathrm{fww}$ ) in eggs of American coots breeding at Bear River Migratory Bird Refuge in Great Salt Lake, Utah, 2010-2012. 


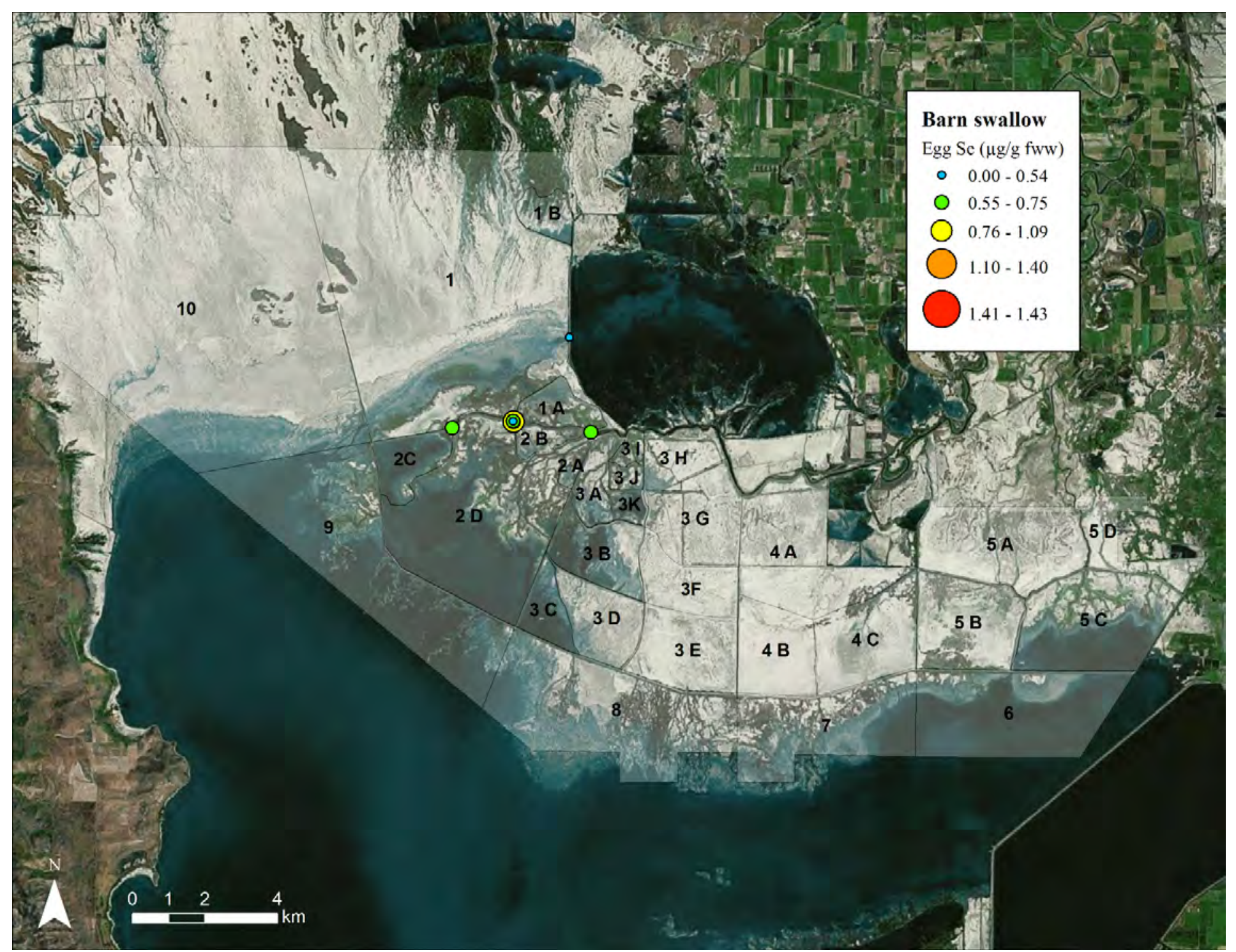

Figure C-4. Selenium concentrations (Se; $\mu \mathrm{g} / \mathrm{g}$ fww) in eggs of barn swallows breeding at Bear River Migratory Bird Refuge in Great Salt Lake, Utah, $2010-2012$. 


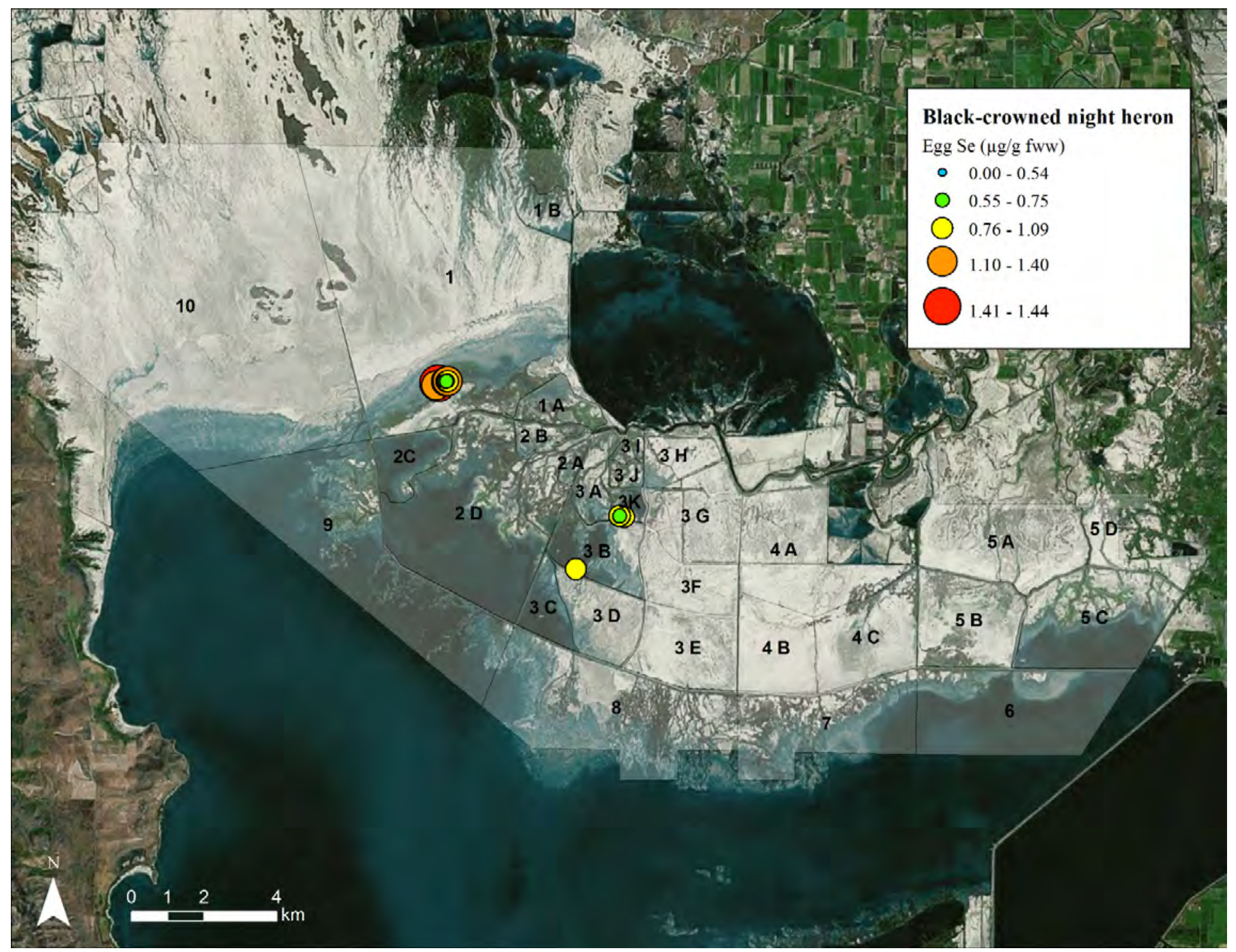

Figure C-5. Selenium concentrations (Se; $\mu \mathrm{g} / \mathrm{g}$ fww) in eggs of black-crowned night herons breeding at Bear River Migratory Bird Refuge in Great Salt Lake, Utah, 20102012. 


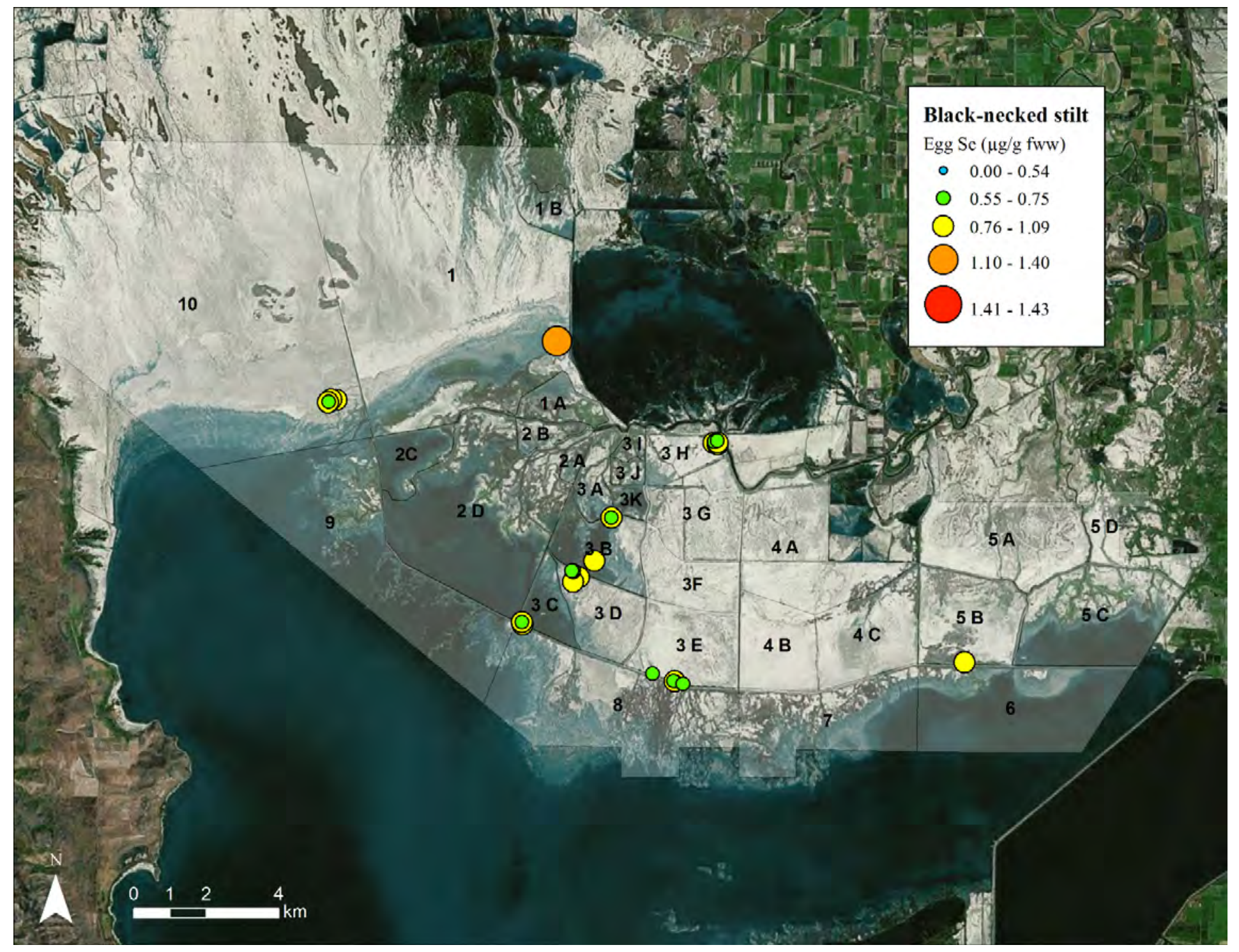

Figure C-6. Selenium concentrations (Se; $\mu \mathrm{g} / \mathrm{g}$ fww) in eggs of black-necked stilts breeding at Bear River Migratory Bird Refuge in Great Salt Lake, Utah, $2010-2012$. 


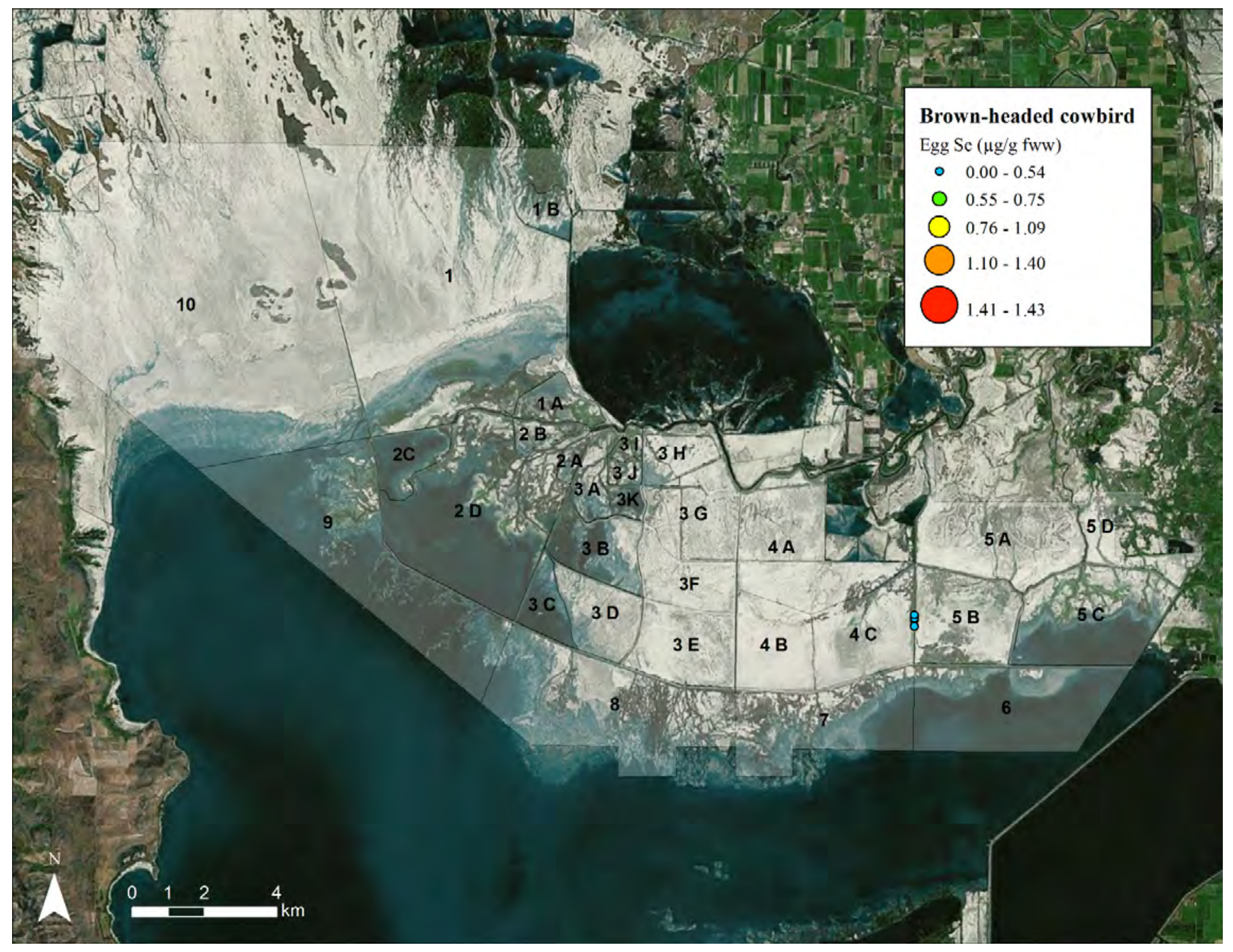

Figure C-7. Selenium concentrations (Se; $\mu \mathrm{g} / \mathrm{g}$ fww) in eggs of black-necked stilts breeding at Bear River Migratory Bird Refuge in Great Salt Lake, Utah, $2010-2012$. 


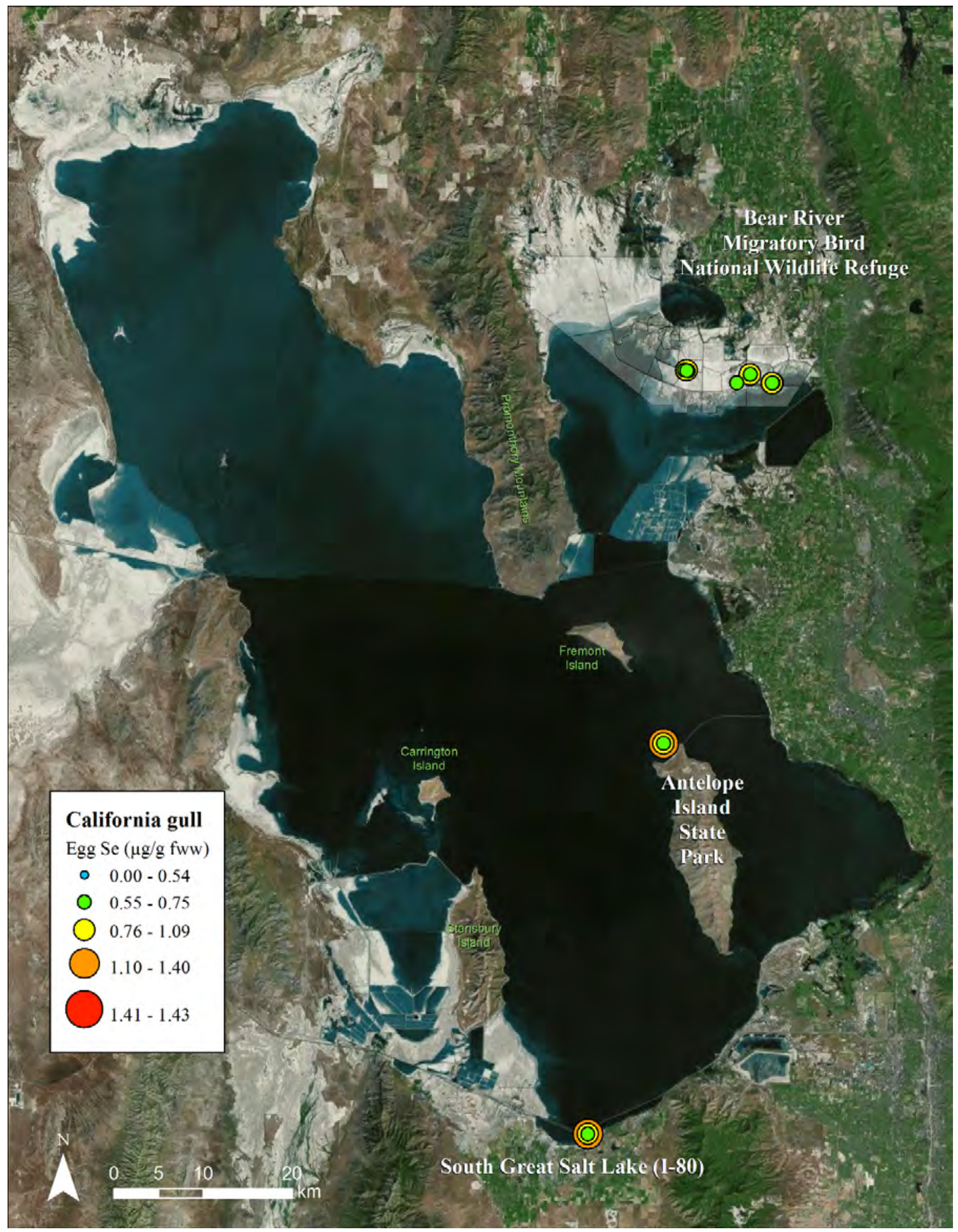

Figure C-8. Selenium concentrations (Se; $\mu \mathrm{g} / \mathrm{g} \mathrm{fww}$ ) in eggs of California gulls breeding in Great Salt Lake, Utah, 2010-2012. 


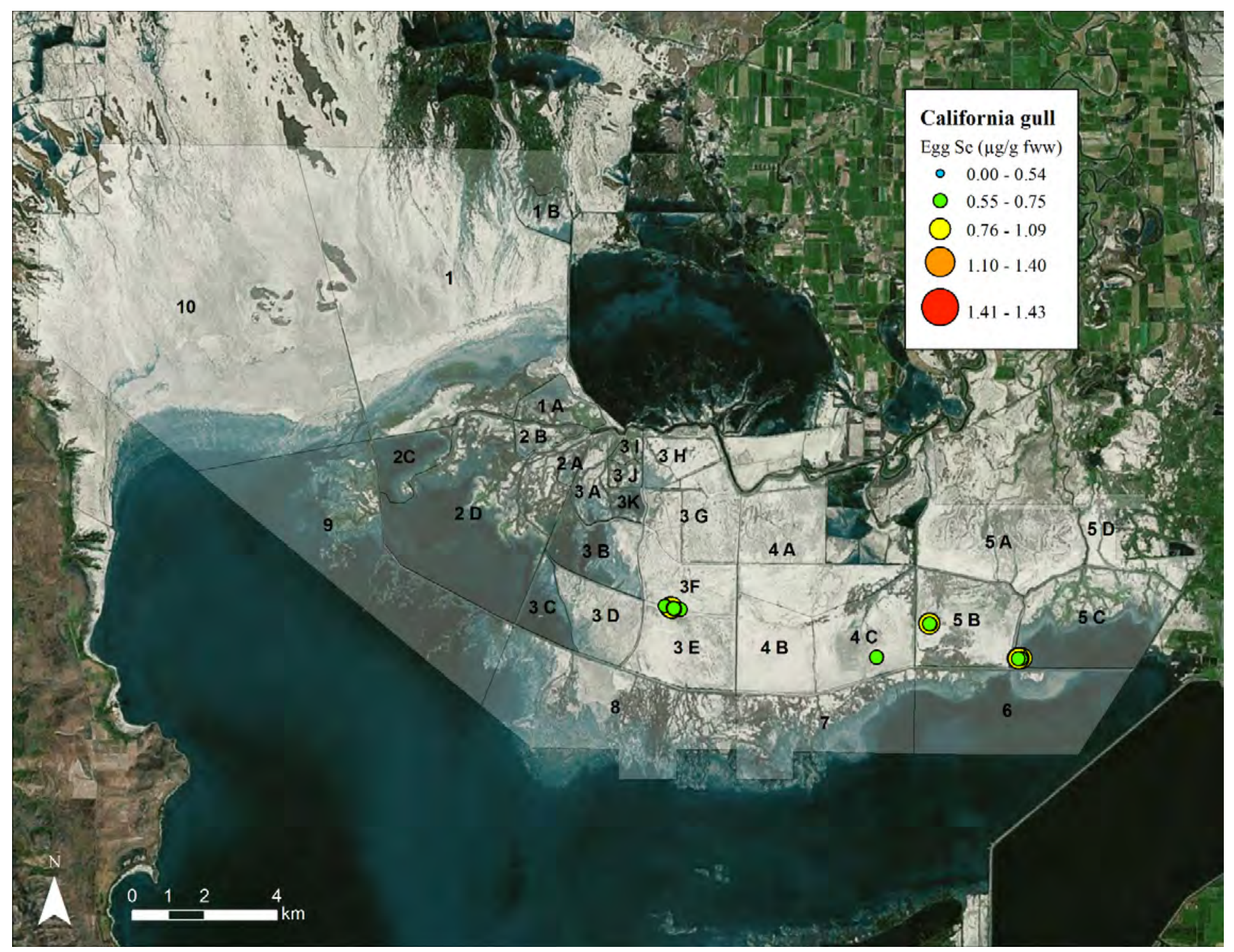

Figure C-9. Selenium concentrations (Se; $\mu \mathrm{g} / \mathrm{g}$ fww) in eggs of California gulls breeding at Bear River Migratory Bird Refuge in Great Salt Lake, Utah, $2010-2012$. 


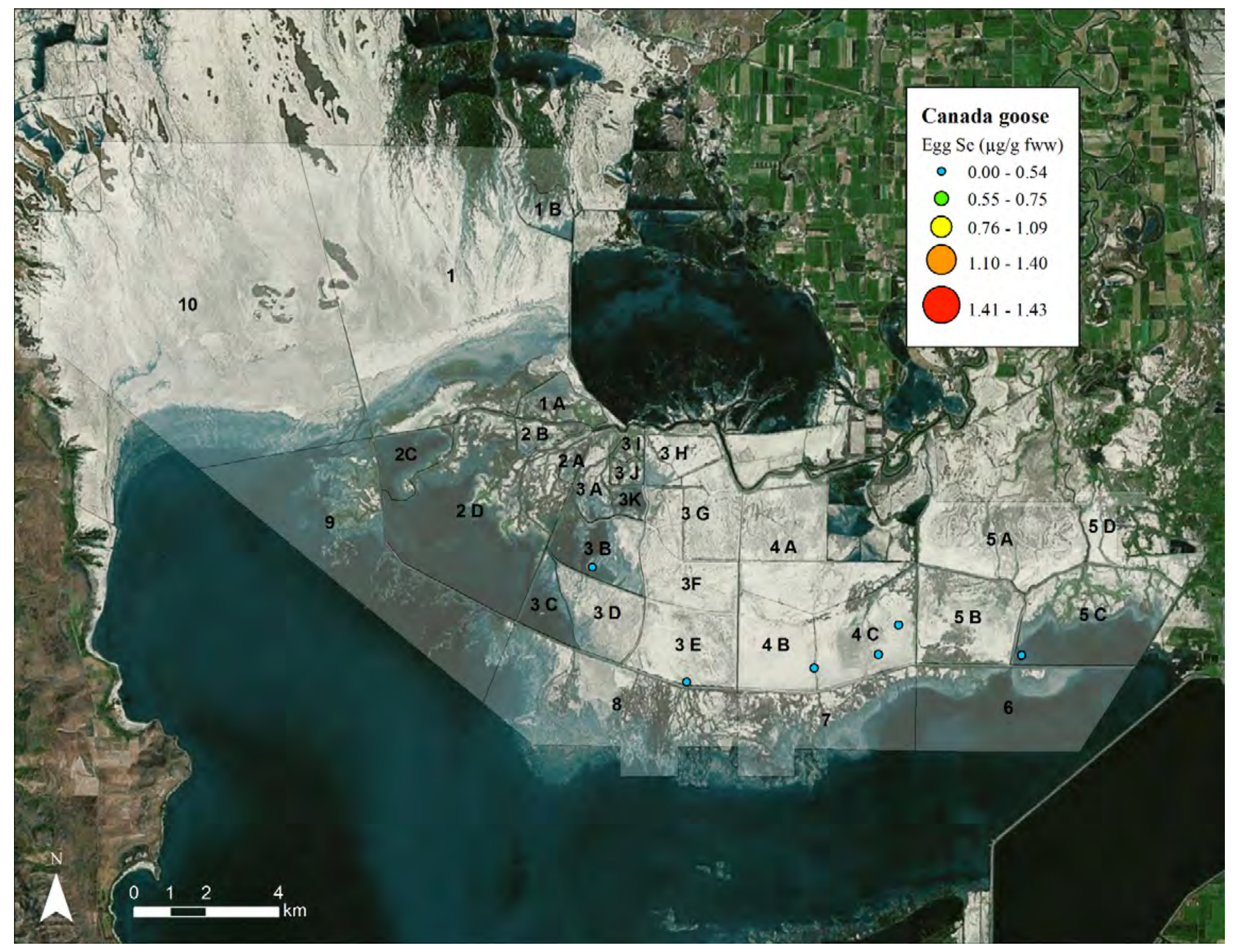

Figure C-10. Selenium concentrations (Se; $\mu \mathrm{g} / \mathrm{g} \mathrm{fww}$ ) in eggs of Canada geese breeding at Bear River Migratory Bird Refuge in Great Salt Lake, Utah, $2010-2012$. 


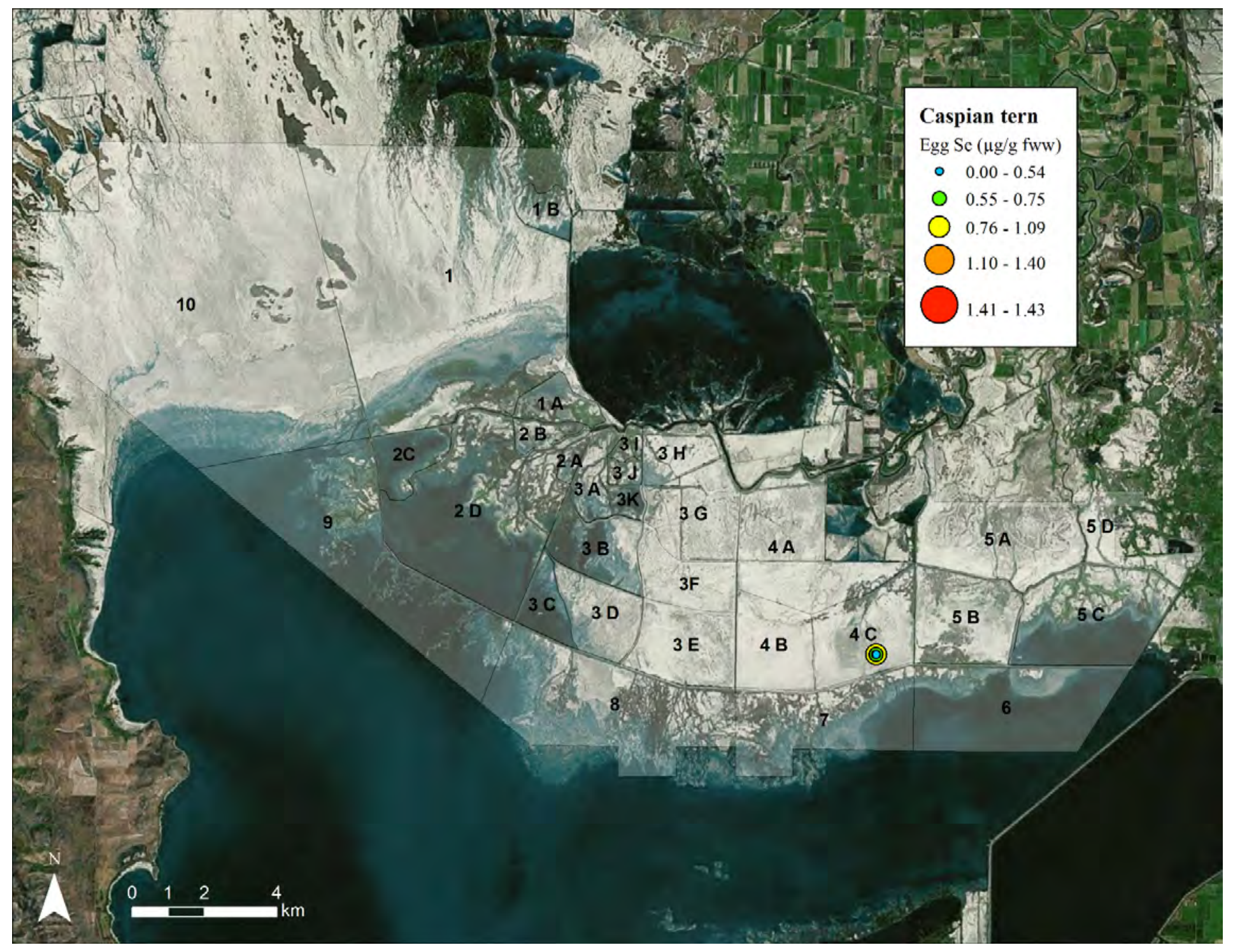

Figure C-11. Selenium concentrations (Se; $\mu \mathrm{g} / \mathrm{g}$ fww) in eggs of Caspian terns breeding at Bear River Migratory Bird Refuge in Great Salt Lake, Utah, 2010-2012. 


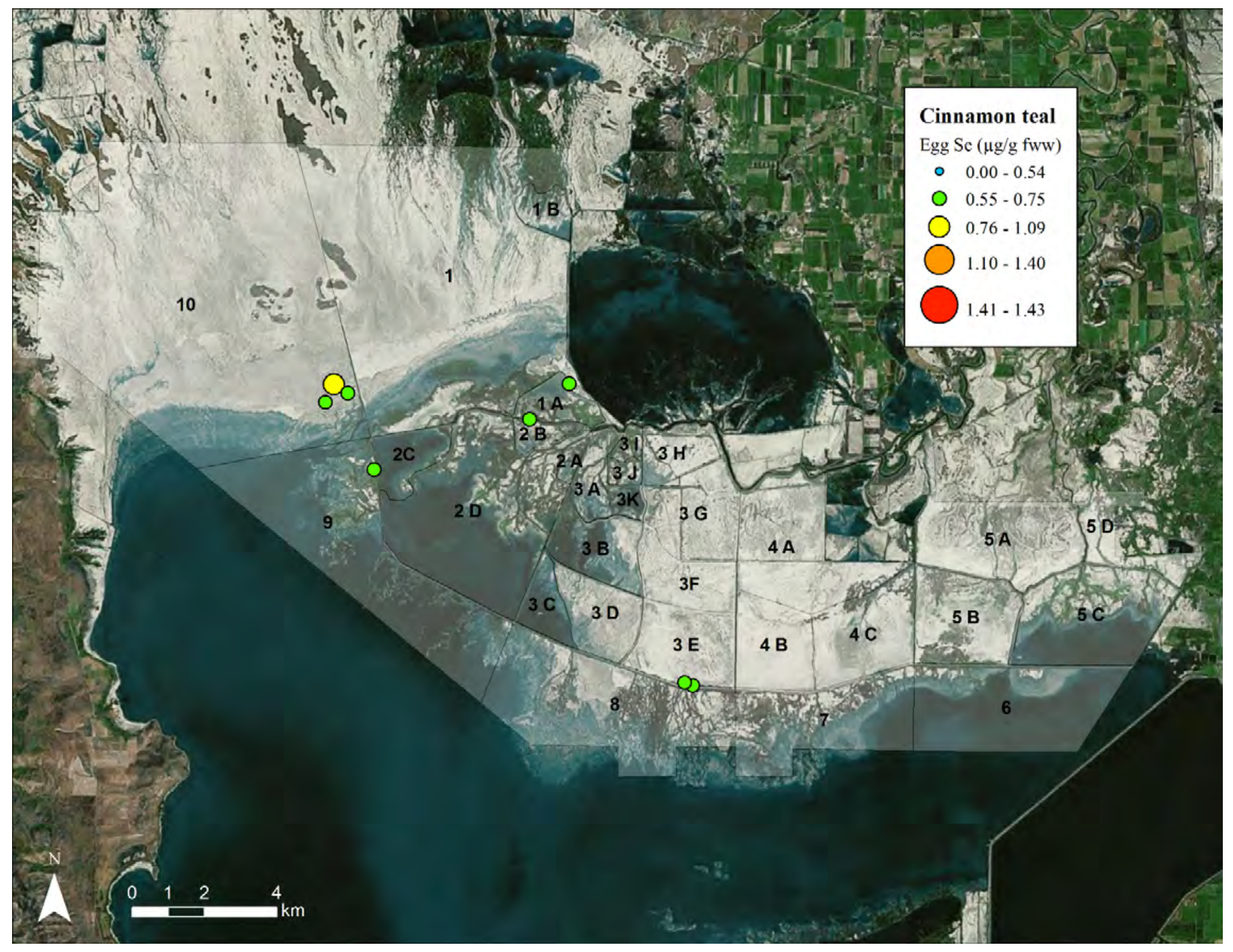

Figure C-12. Selenium concentrations (Se; $\mu \mathrm{g} / \mathrm{g}$ fww) in eggs of cinnamon teal breeding at Bear River Migratory Bird Refuge in Great Salt Lake, Utah, $2010-2012$. 


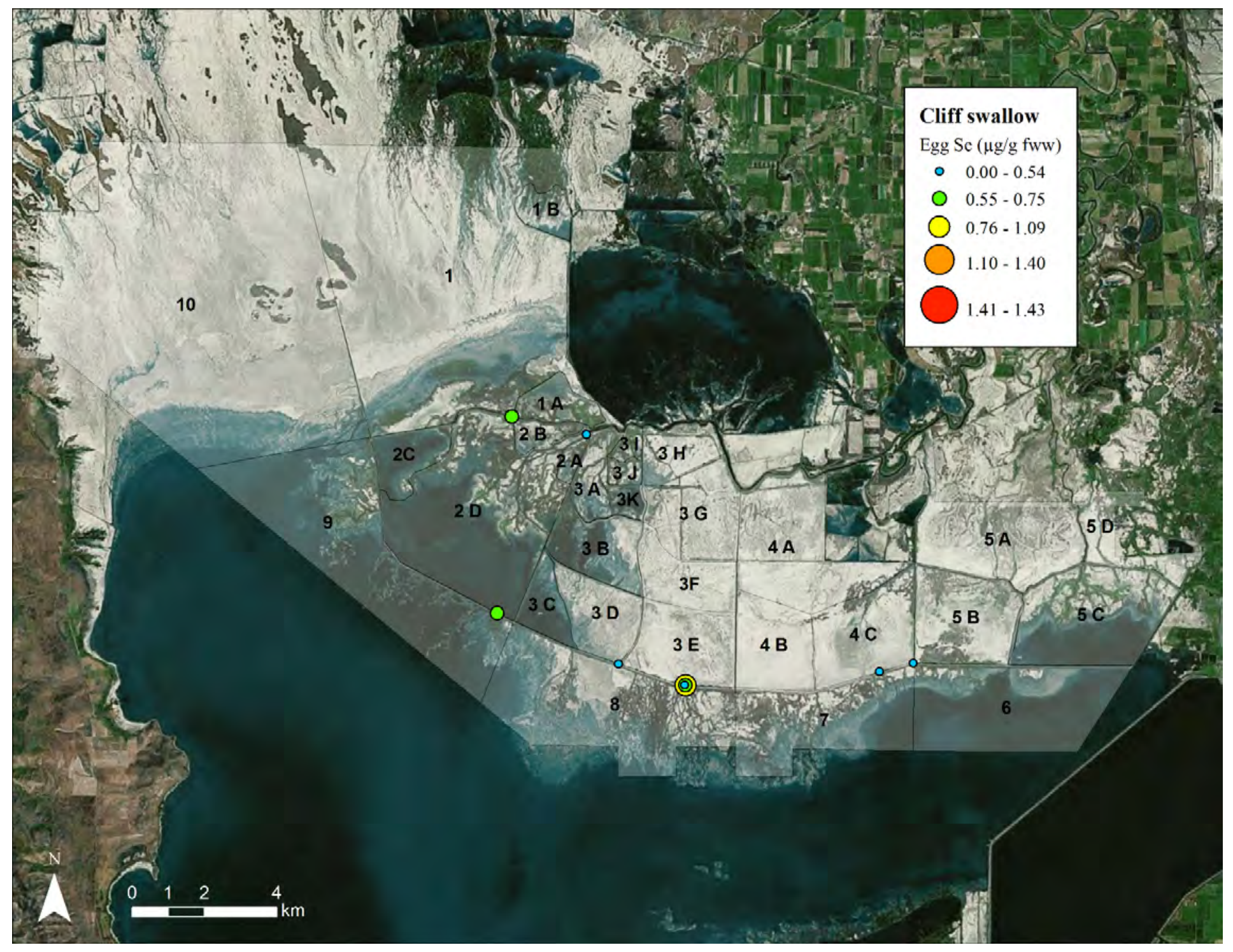

Figure C-13. Selenium concentrations (Se; $\mu \mathrm{g} / \mathrm{g}$ fww) in eggs of cliff swallows breeding at Bear River Migratory Bird Refuge in Great Salt Lake, Utah, 2010-2012. 


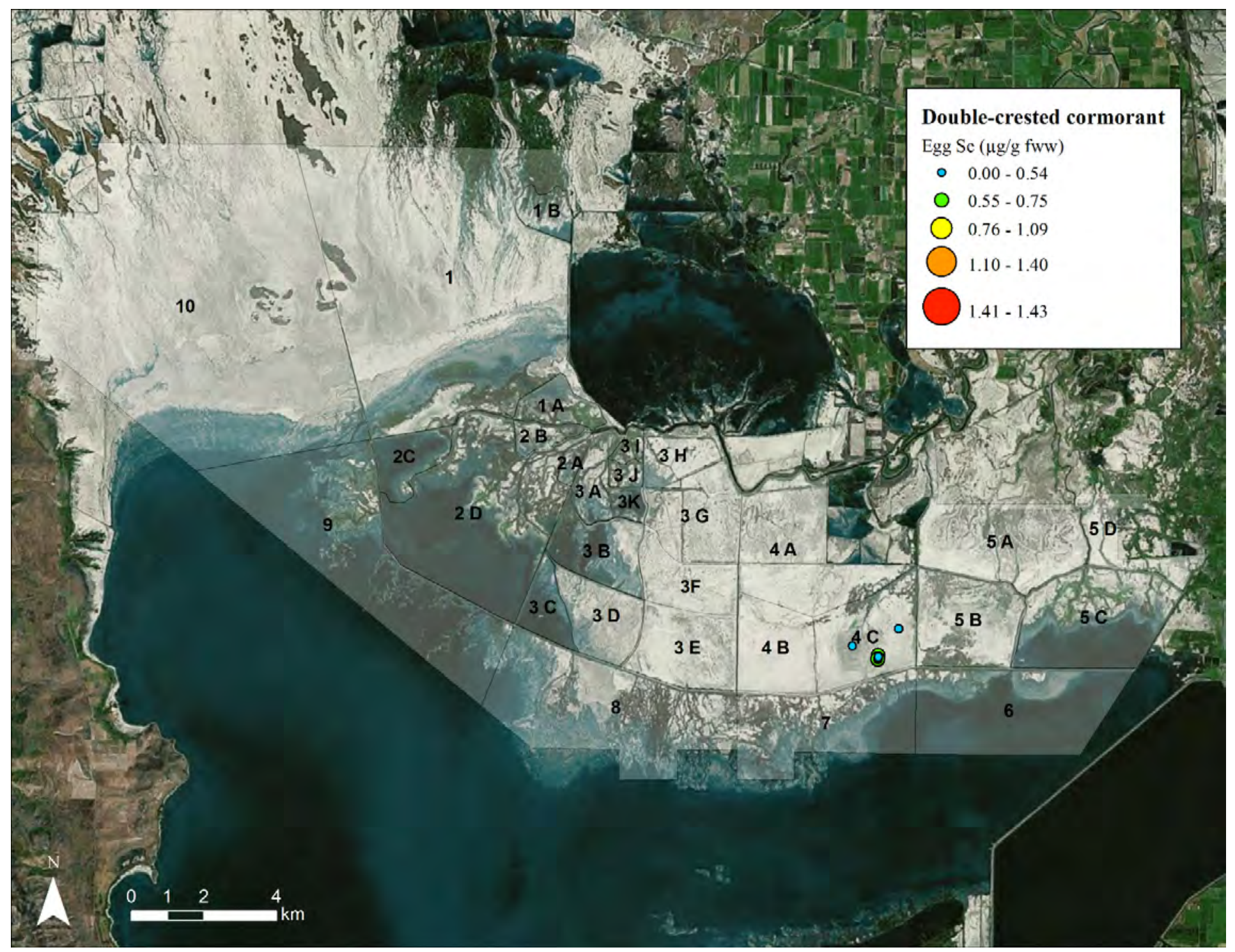

Figure C-14. Selenium concentrations (Se; $\mu \mathrm{g} / \mathrm{g}$ fww) in eggs of double-crested cormorants breeding at Bear River Migratory Bird Refuge in Great Salt Lake, Utah, 2010-2012. 


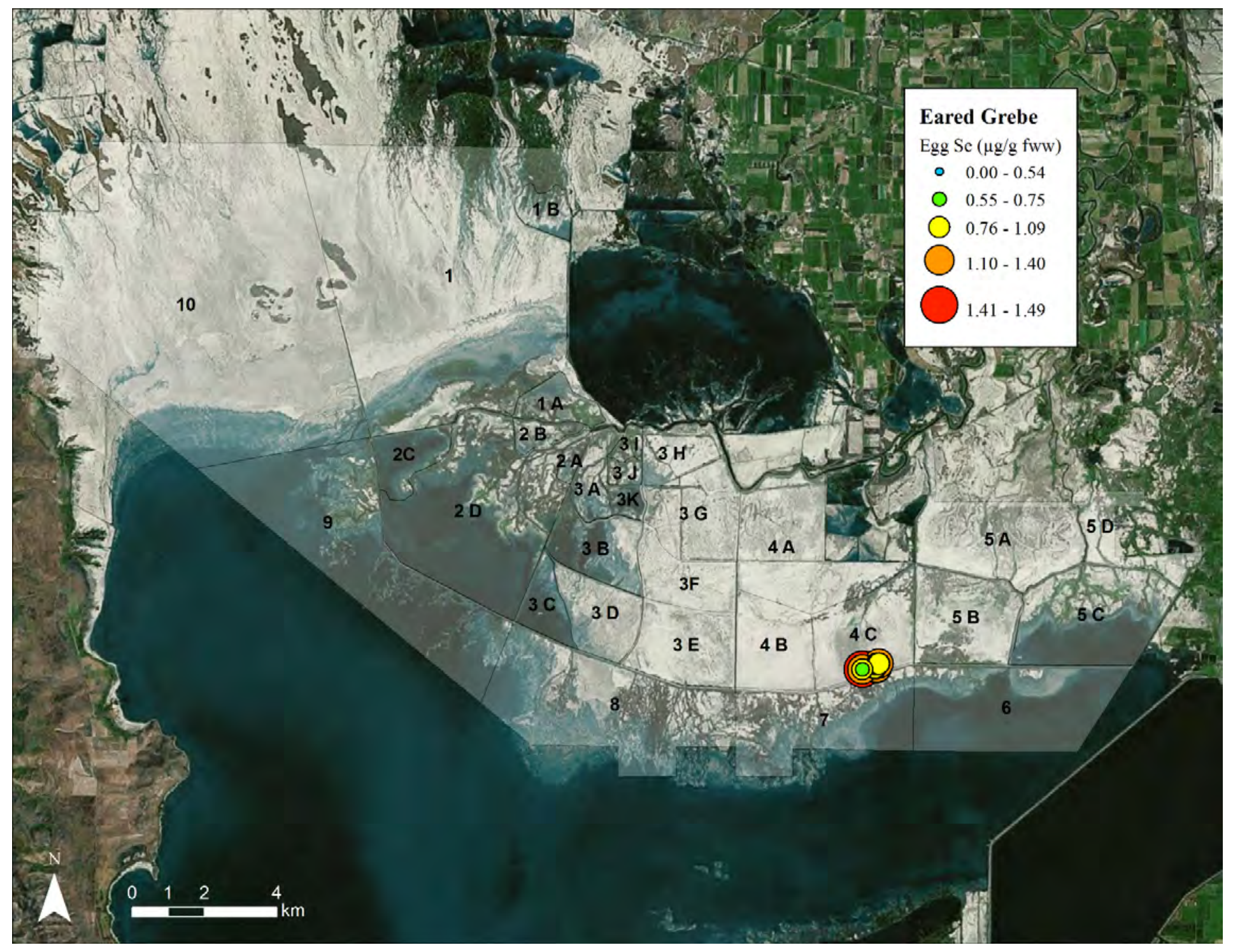

Figure C-15. Selenium concentrations (Se; $\mu \mathrm{g} / \mathrm{g}$ fww) in eggs of eared grebes breeding at Bear River Migratory Bird Refuge in Great Salt Lake, Utah, $2010-2012$. 


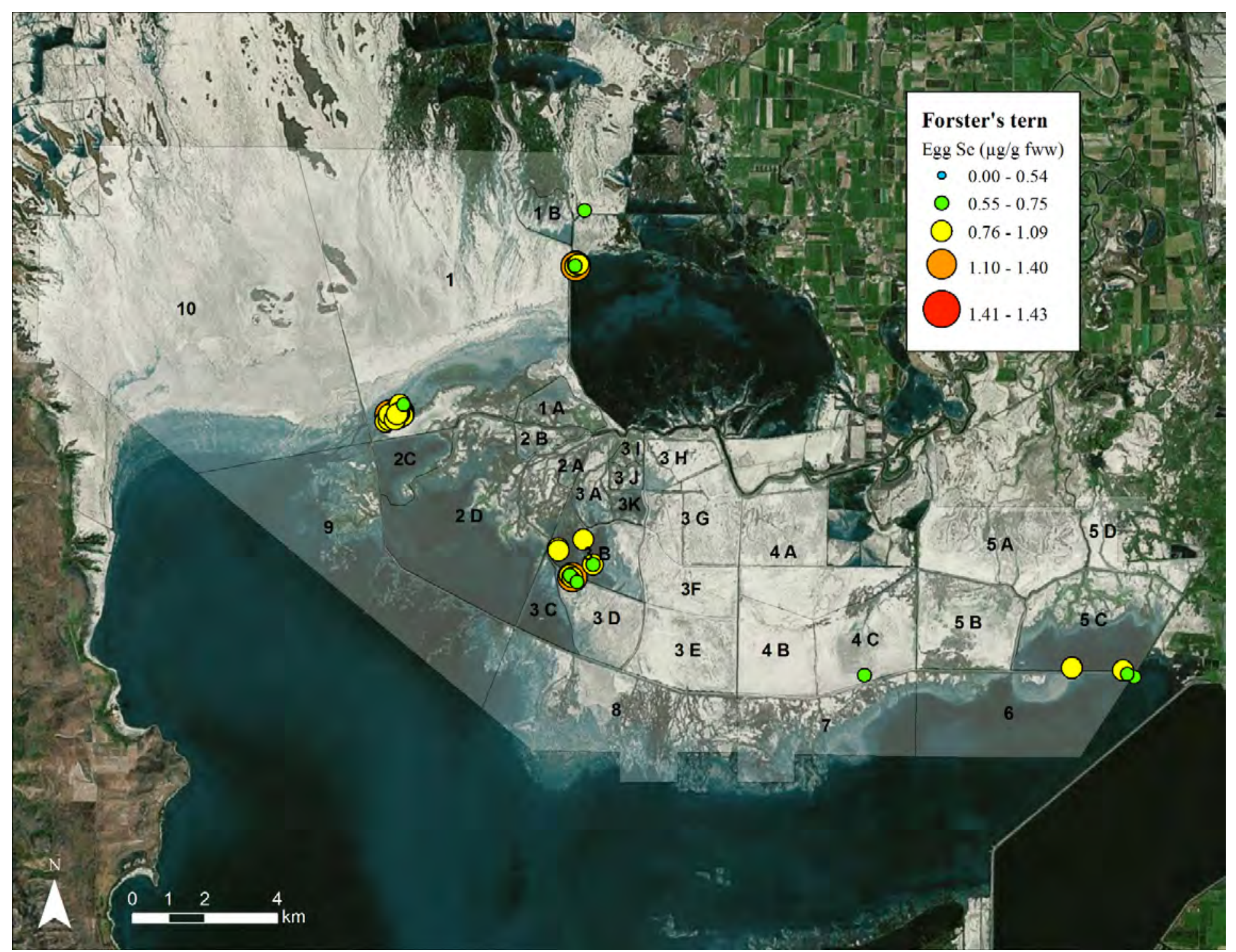

Figure C-16. Selenium concentrations (Se; $\mu \mathrm{g} / \mathrm{g}$ fww) in eggs of Forster's terns breeding at Bear River Migratory Bird Refuge in Great Salt Lake, Utah, $2010-2012$. 


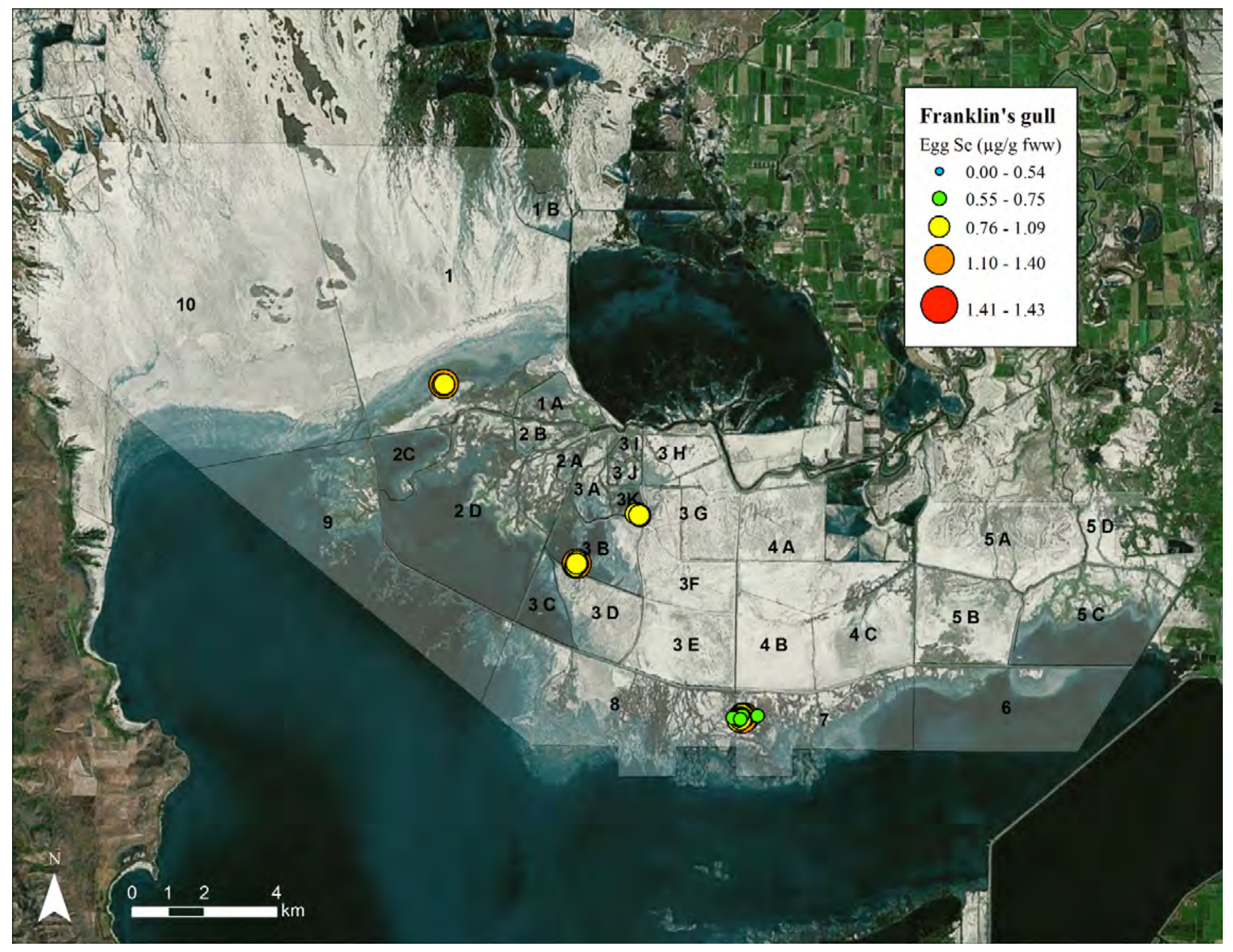

Figure C-17. Selenium concentrations (Se; $\mu \mathrm{g} / \mathrm{g} \mathrm{fww)} \mathrm{in} \mathrm{eggs} \mathrm{of} \mathrm{Franklin's} \mathrm{gulls} \mathrm{breeding} \mathrm{at} \mathrm{Bear} \mathrm{River} \mathrm{Migratory} \mathrm{Bird} \mathrm{Refuge} \mathrm{in} \mathrm{Great} \mathrm{Salt} \mathrm{Lake,} \mathrm{Utah,} 2010-2012$. 


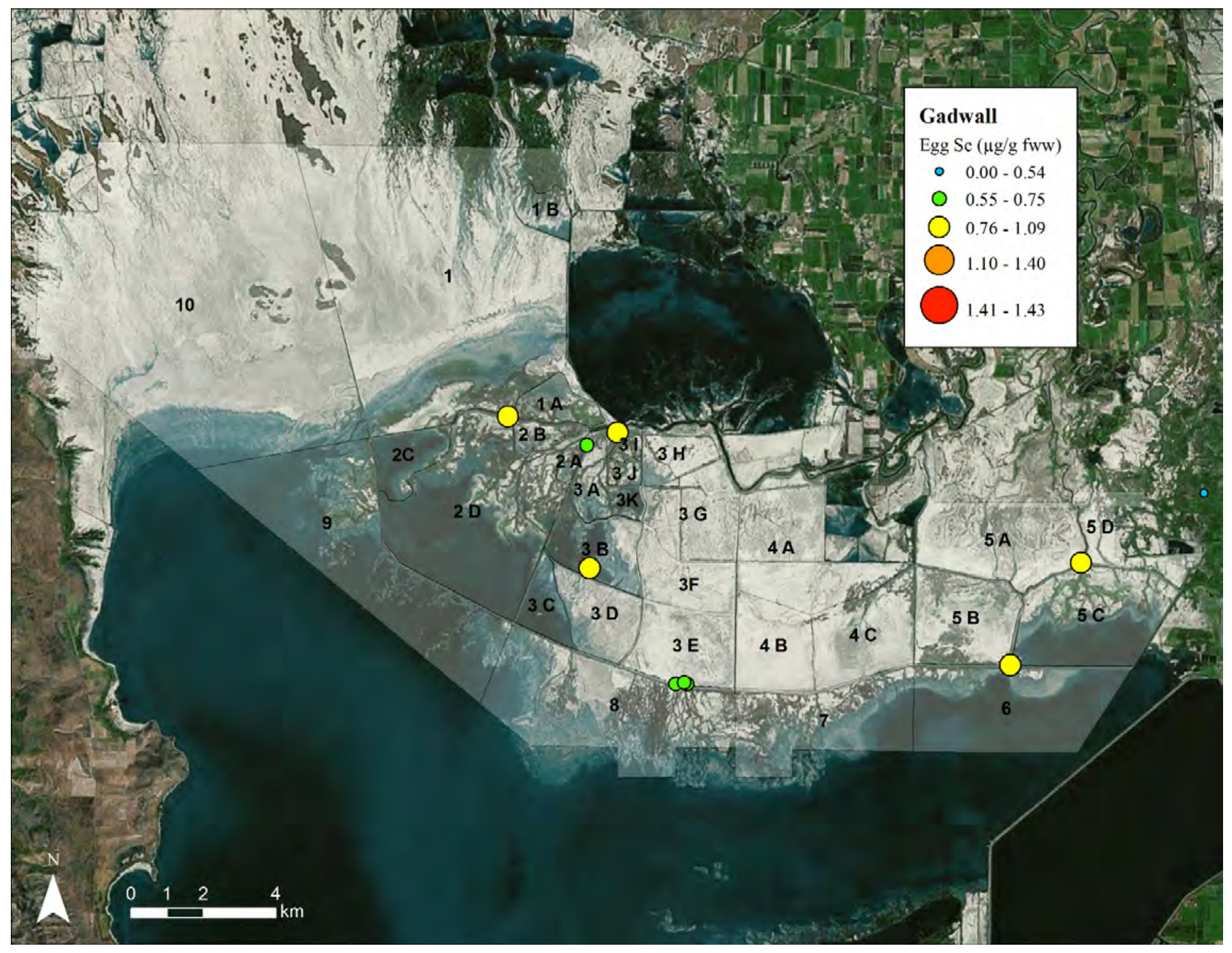

Figure C-18. Selenium concentrations (Se; $\mu \mathrm{g} / \mathrm{g}$ fww) in eggs of gadwall breeding at Bear River Migratory Bird Refuge in Great Salt Lake, Utah, $2010-2012$. 


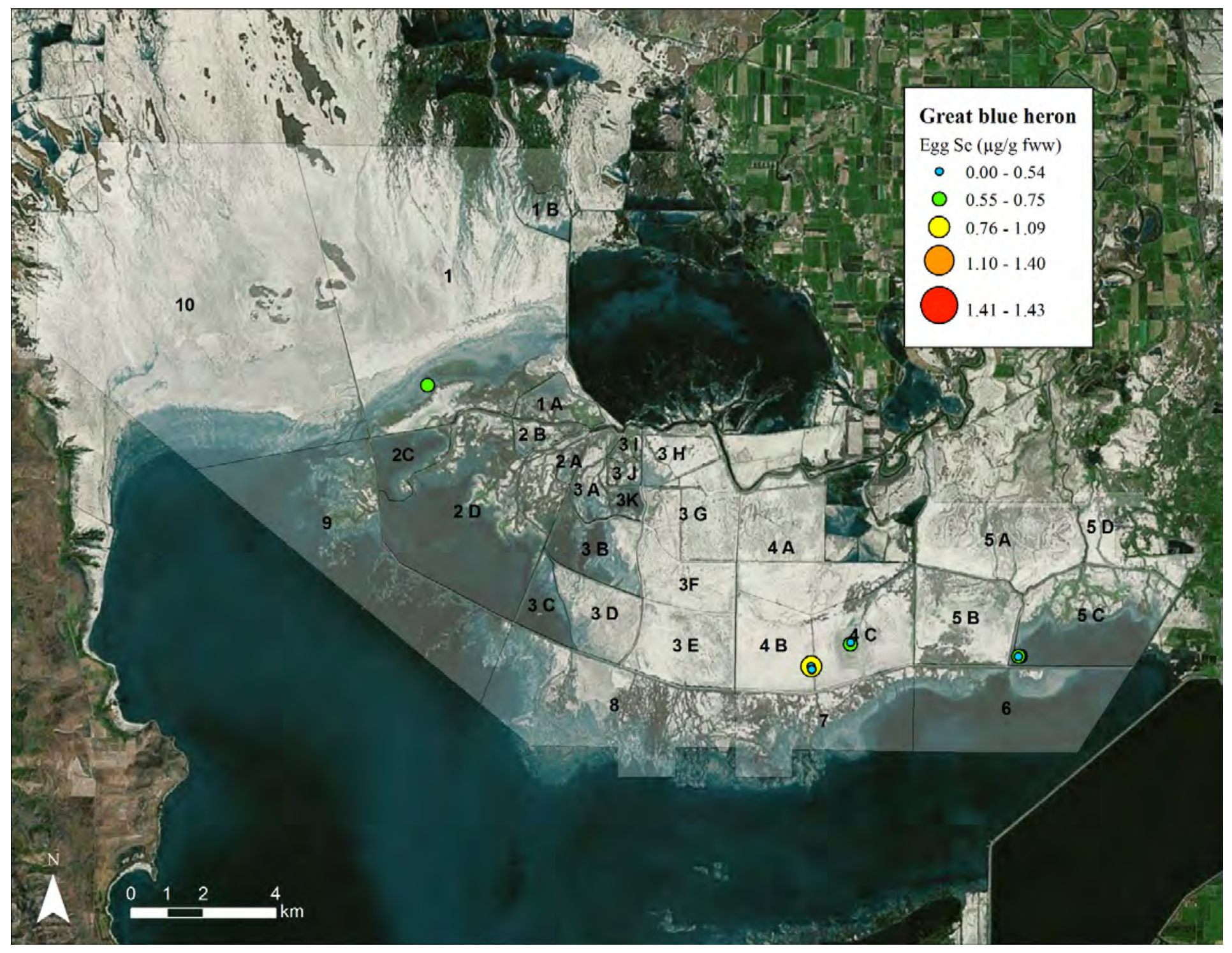

Figure C-19. Selenium concentrations (Se; $\mu \mathrm{g} / \mathrm{g}$ fww) in eggs of great blue herons breeding at Bear River Migratory Bird Refuge in Great Salt Lake, Utah, $2010-2012$. 


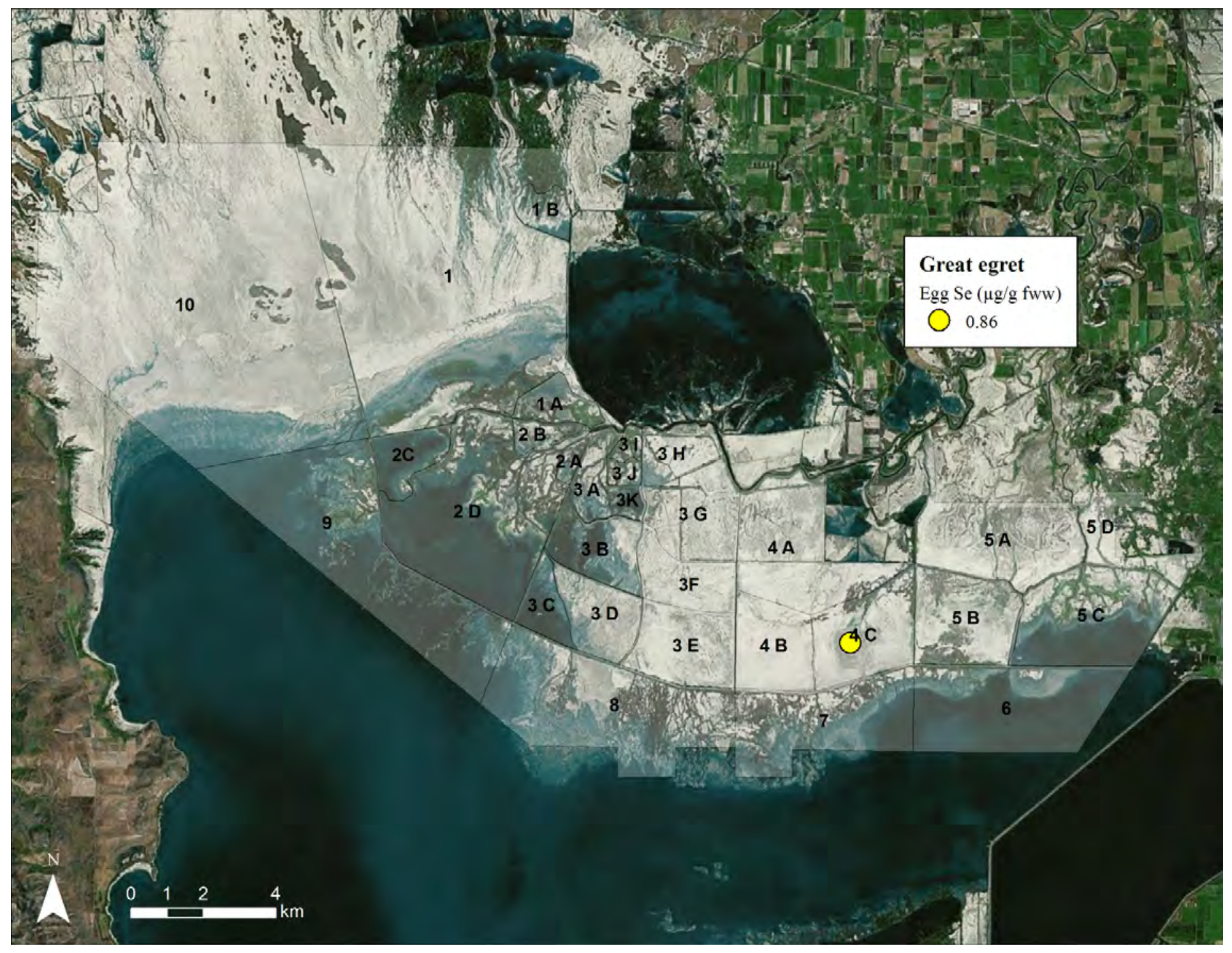

Figure C-20. Selenium concentrations (Se; $\mu \mathrm{g} / \mathrm{g} \mathrm{fww)} \mathrm{in} \mathrm{eggs} \mathrm{of} \mathrm{great} \mathrm{egrets} \mathrm{breeding} \mathrm{at} \mathrm{Bear} \mathrm{River} \mathrm{Migratory} \mathrm{Bird} \mathrm{Refuge} \mathrm{in} \mathrm{Great} \mathrm{Salt} \mathrm{Lake,} \mathrm{Utah,} 2010-2012$. 


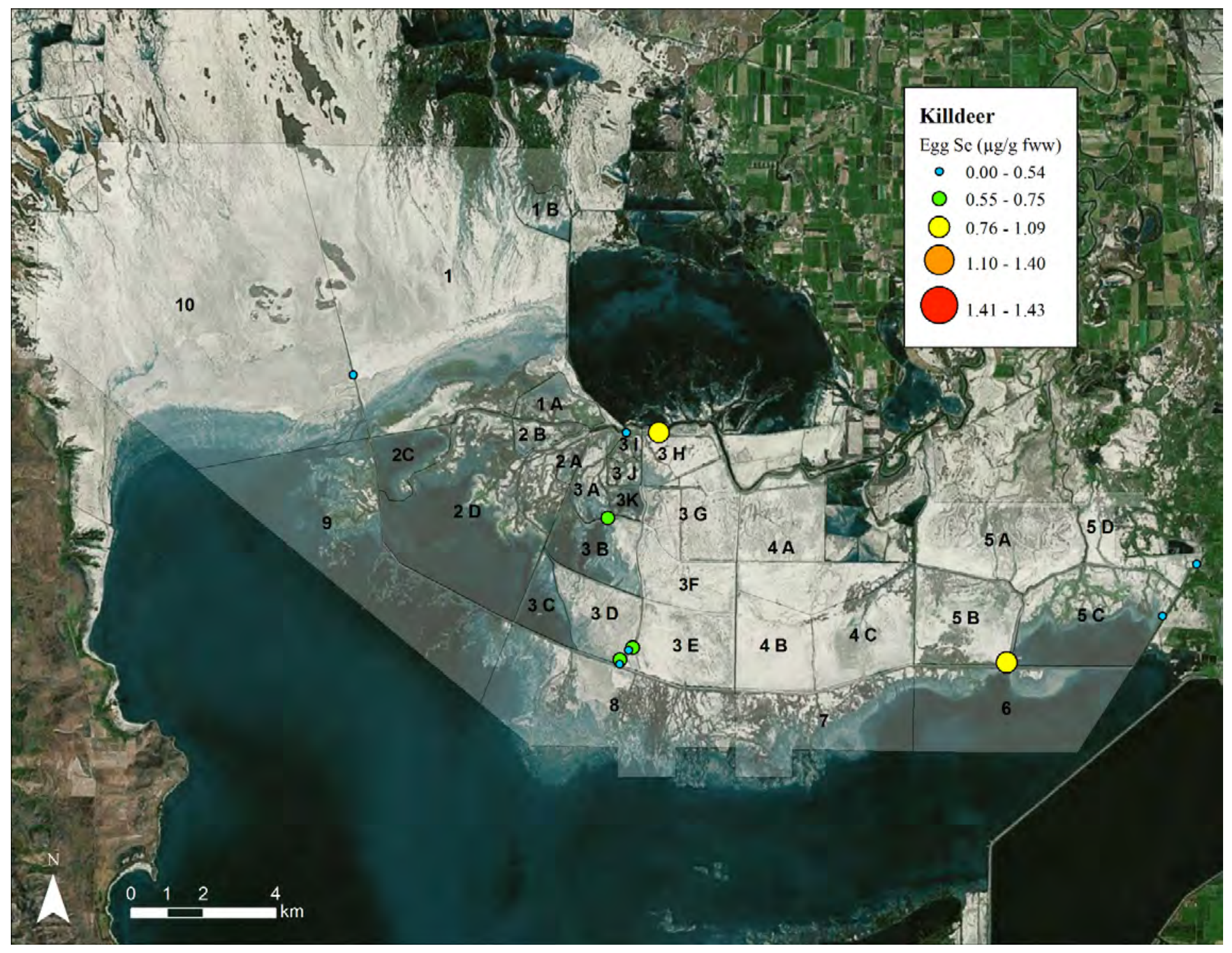

Figure C-21. Selenium concentrations (Se; $\mu \mathrm{g} / \mathrm{g}$ fww) in eggs of killdeer breeding at Bear River Migratory Bird Refuge in Great Salt Lake, Utah, $2010-2012$. 


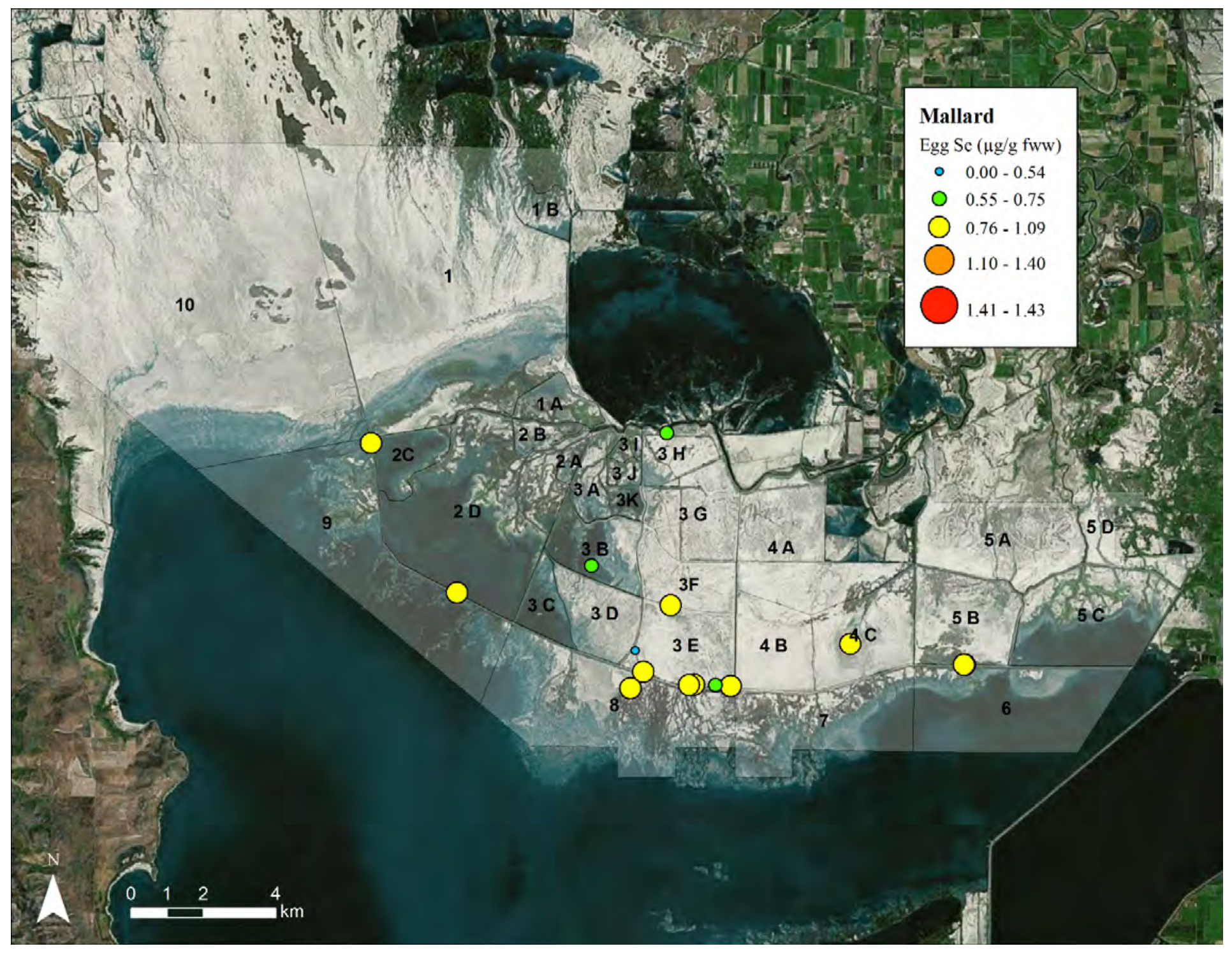

Figure C-22. Selenium concentrations (Se; $\mu \mathrm{g} / \mathrm{g}$ fww) in eggs of mallard breeding at Bear River Migratory Bird Refuge in Great Salt Lake, Utah, $2010-2012$. 


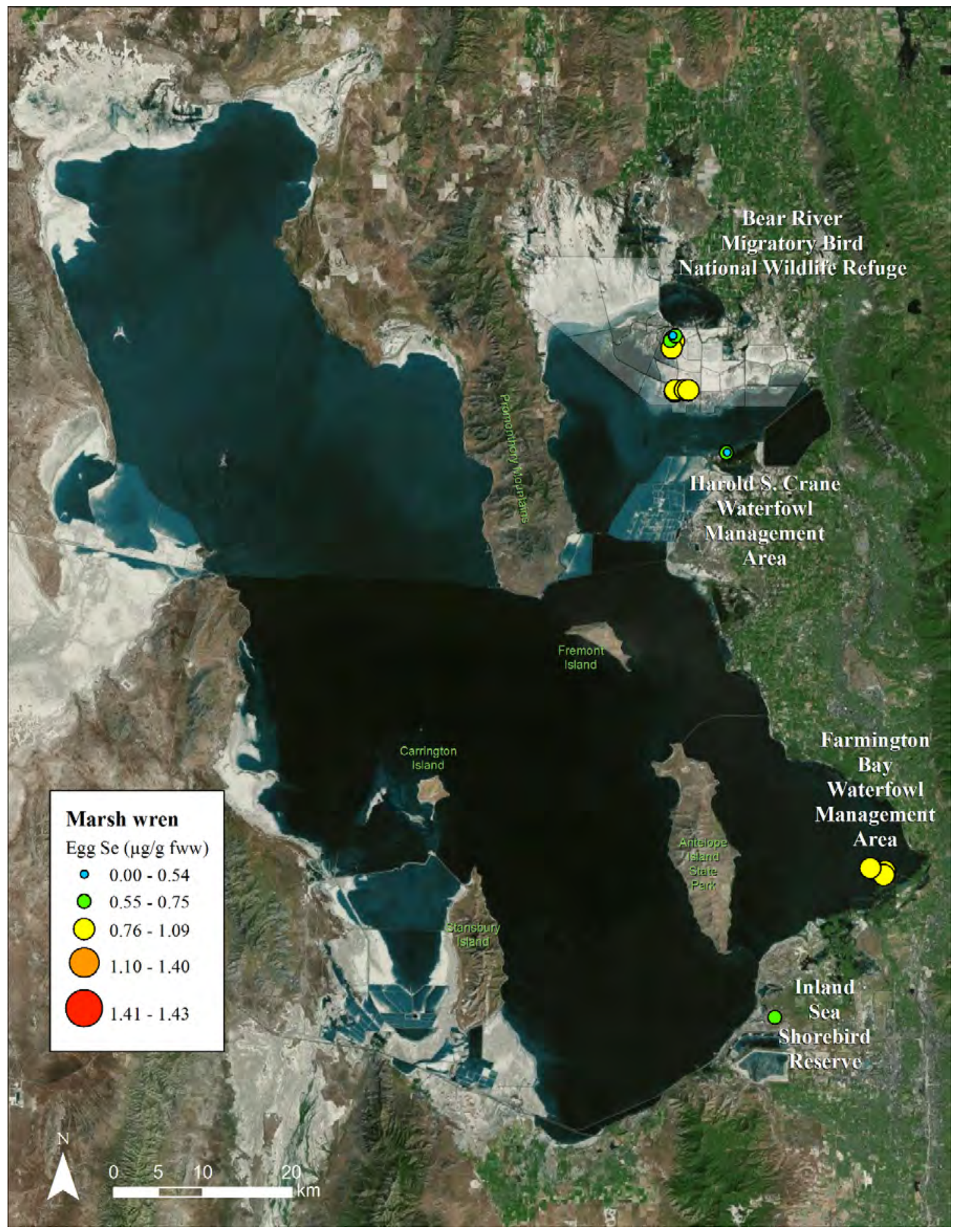

Figure C-23. Selenium concentrations (Se; $\mu \mathrm{g} / \mathrm{g}$ fww) in eggs of marsh wrens breeding in Great Salt Lake, Utah, 2010-2012. 


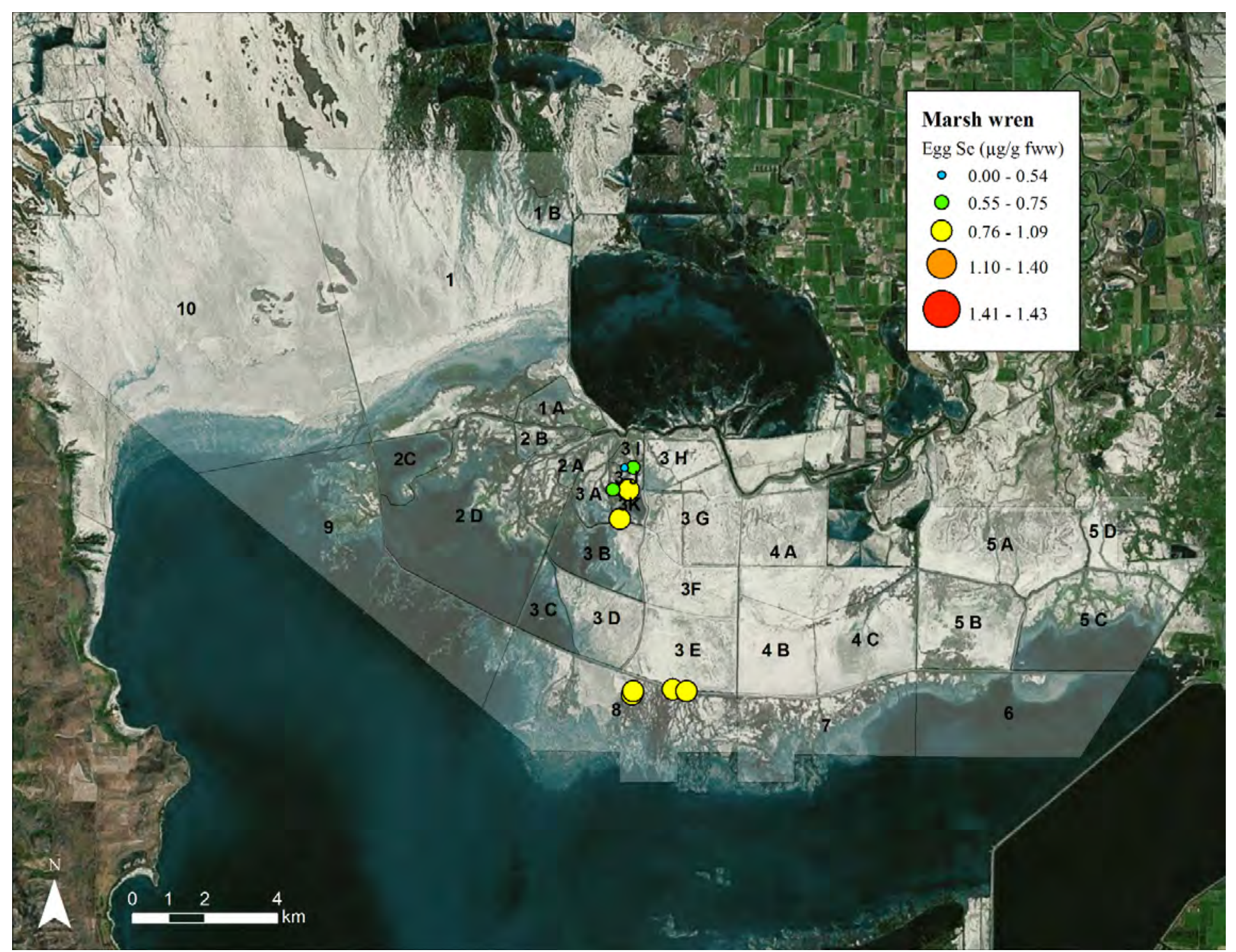

Figure C-24. Selenium concentrations (Se; $\mu \mathrm{g} / \mathrm{g}$ fuw) in eggs of marsh wrens breeding at Bear River Migratory Bird Refuge in Great Salt Lake, Utah, 2010-2012. 


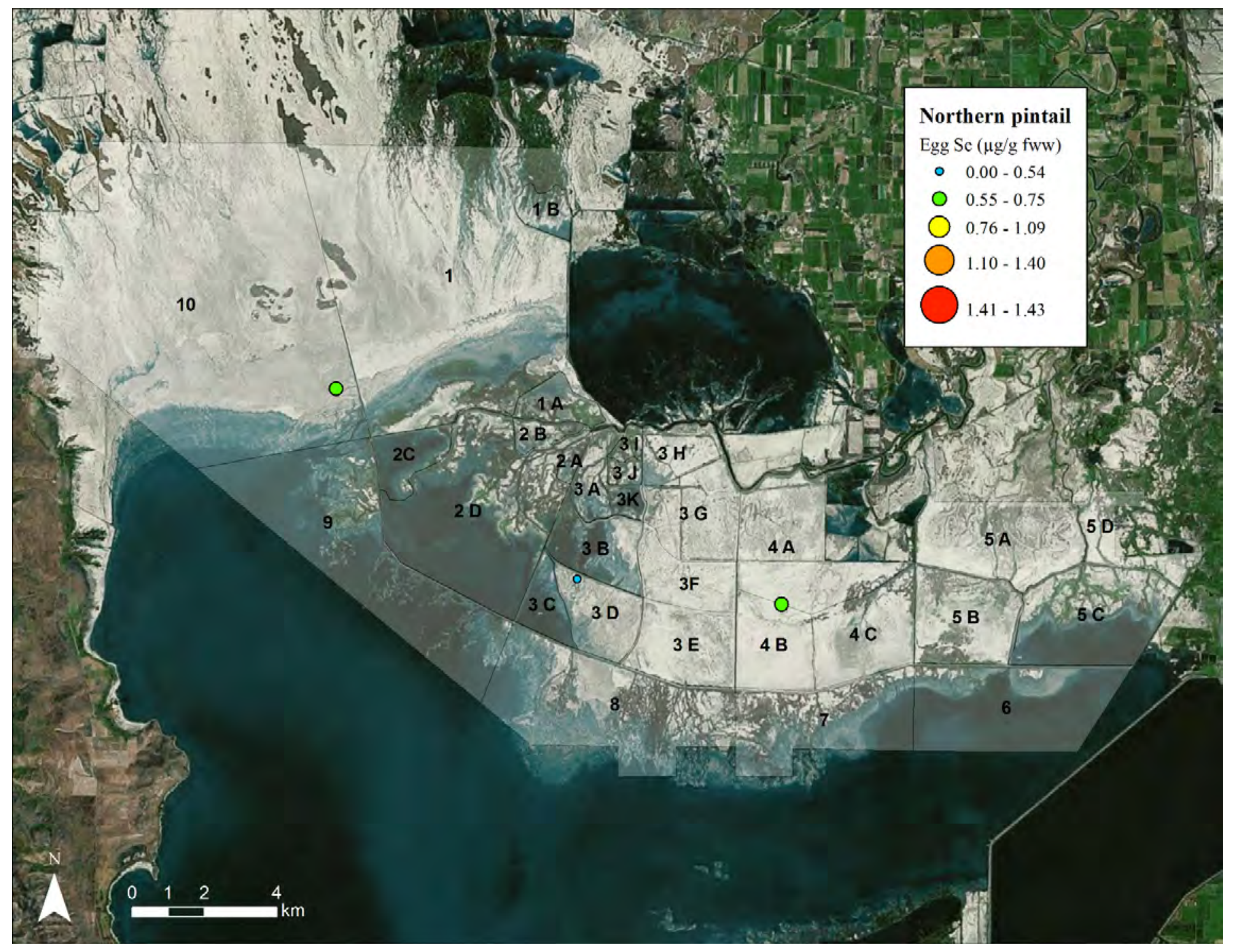

Figure C-25. Selenium concentrations (Se; $\mu \mathrm{g} / \mathrm{g} \mathrm{fww)} \mathrm{in} \mathrm{eggs} \mathrm{of} \mathrm{northern} \mathrm{pintail} \mathrm{breeding} \mathrm{at} \mathrm{Bear} \mathrm{River} \mathrm{Migratory} \mathrm{Bird} \mathrm{Refuge} \mathrm{in} \mathrm{Great} \mathrm{Salt} \mathrm{Lake,} \mathrm{Utah,} 2010-2012$. 


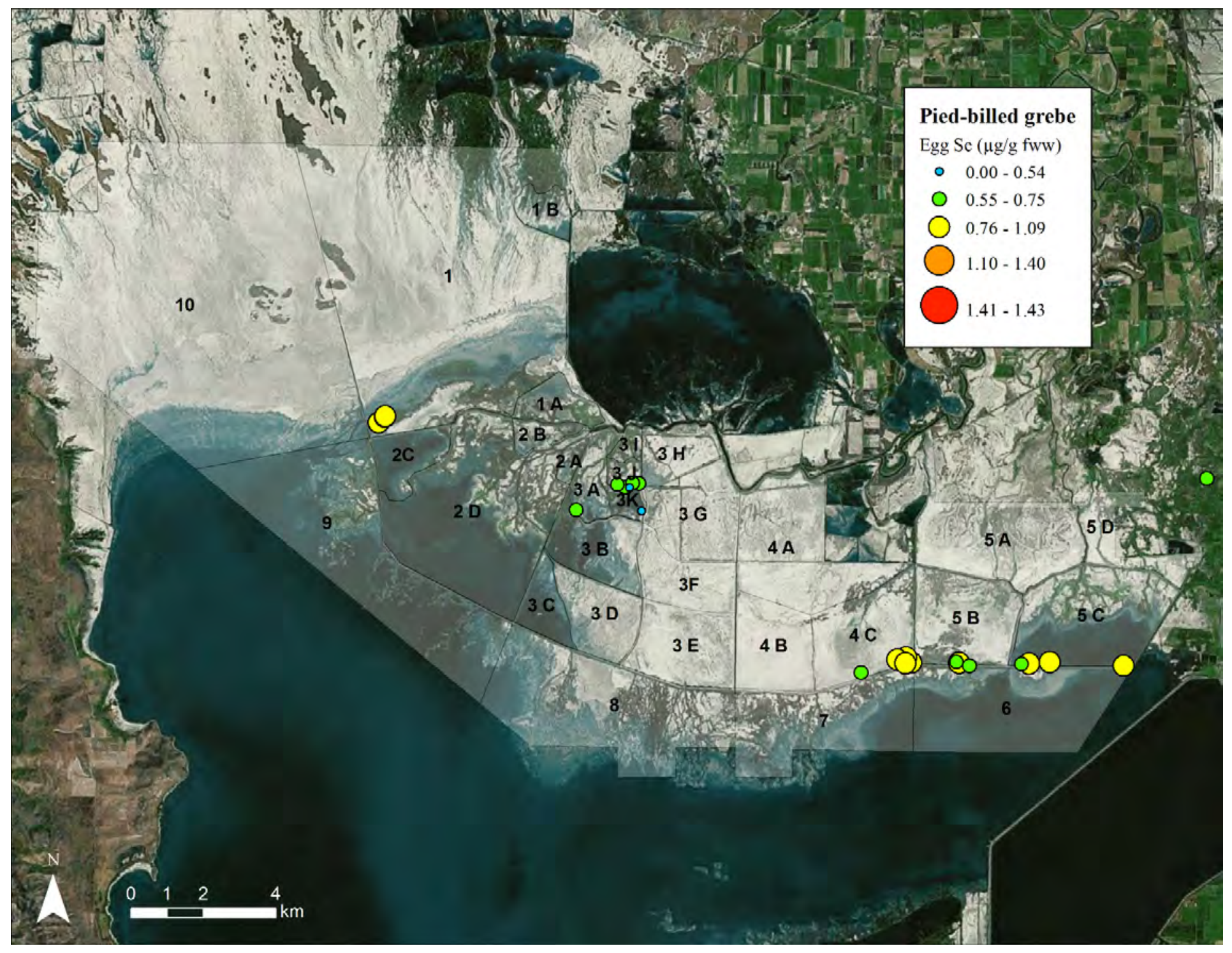

Figure C-26. Selenium concentrations (Se; $\mu \mathrm{g} / \mathrm{g}$ fww) in eggs of pied-billed grebes breeding at Bear River Migratory Bird Refuge in Great Salt Lake, Utah, $2010-2012$. 


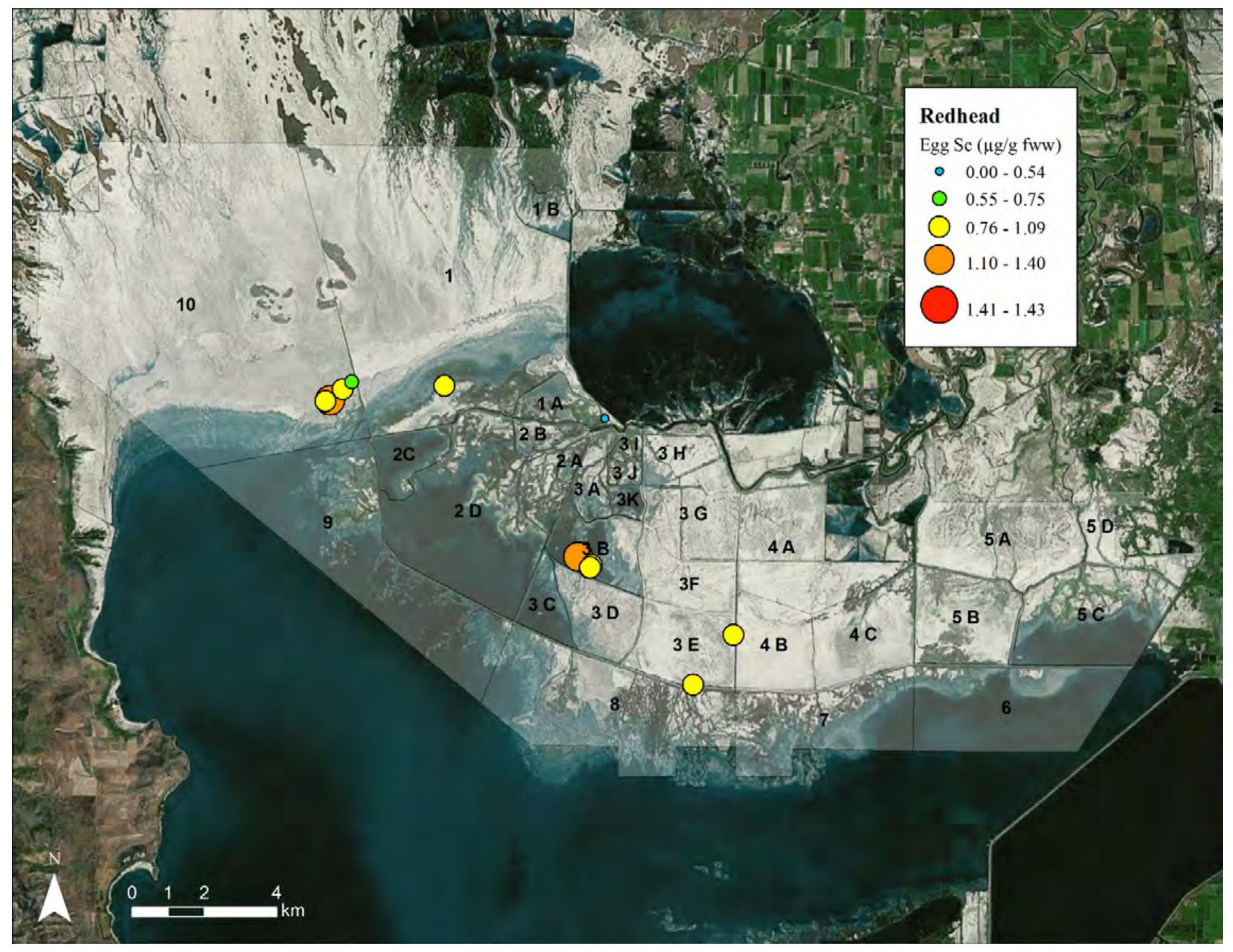

Figure C-27. Selenium concentrations (Se; $\mu \mathrm{g} / \mathrm{g} \mathrm{fww}$ ) in eggs of redhead ducks breeding at Bear River Migratory Bird Refuge in Great Salt Lake, Utah, $2010-2012$. 


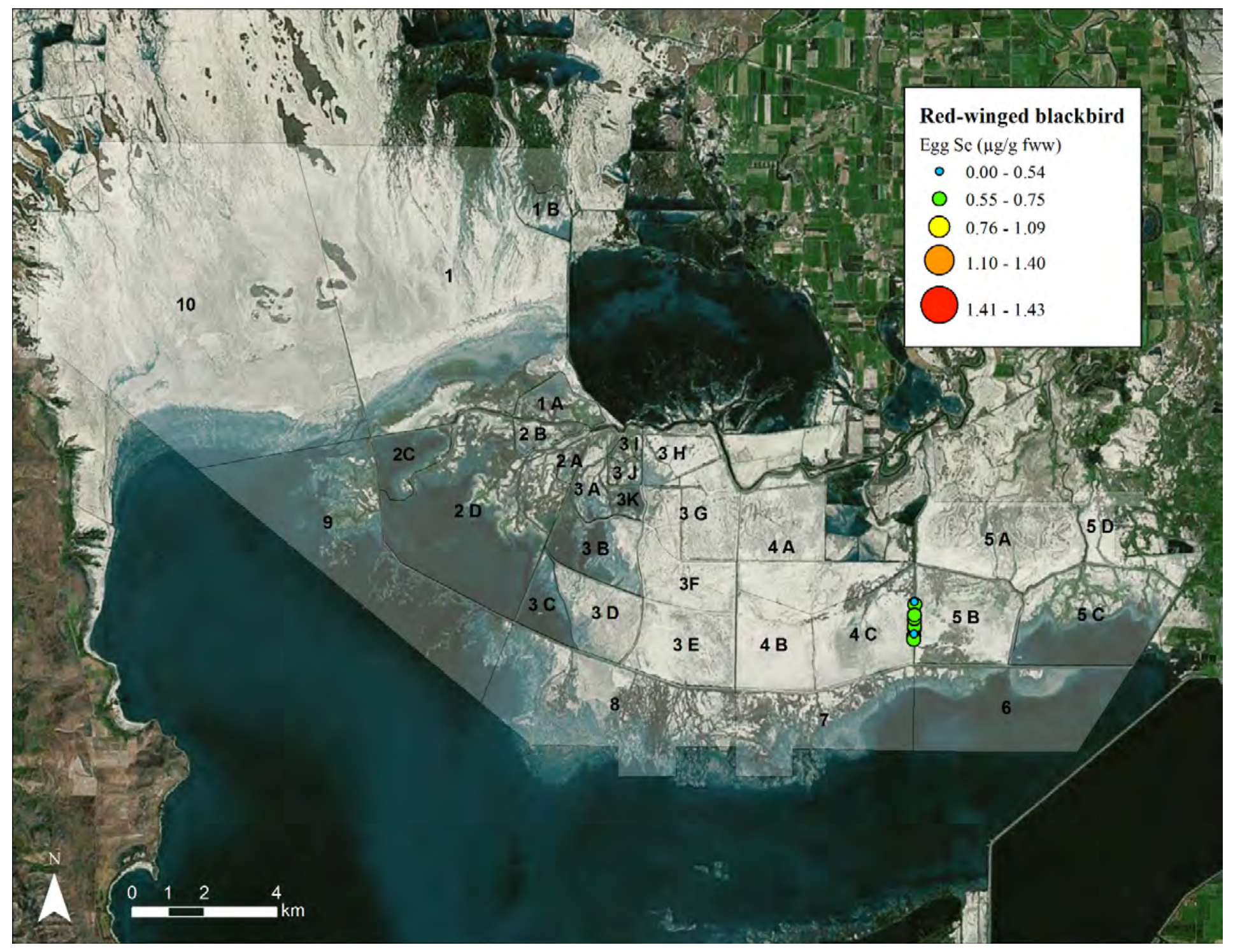

Figure C-28. Selenium concentrations (Se; $\mu \mathrm{g} / \mathrm{g}$ fww) in eggs of red-winged blackbirds breeding at Bear River Migratory Bird Refuge in Great Salt Lake, Utah, $2010-2012$. 


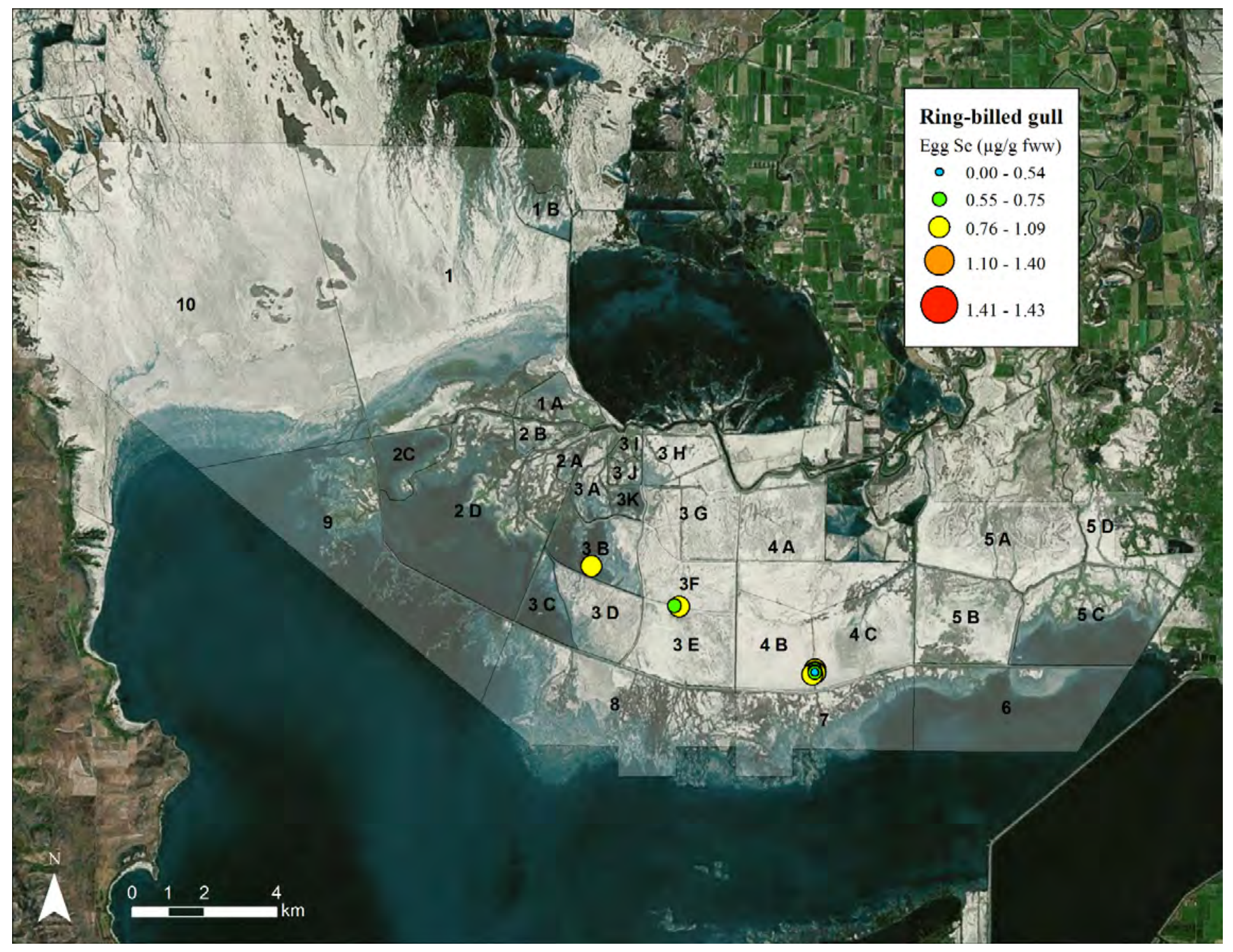

Figure C-29. Selenium concentrations (Se; $\mu \mathrm{g} / \mathrm{g} \mathrm{fww}$ ) in eggs of ring-billed gulls breeding at Bear River Migratory Bird Refuge in Great Salt Lake, Utah, $2010-2012$. 


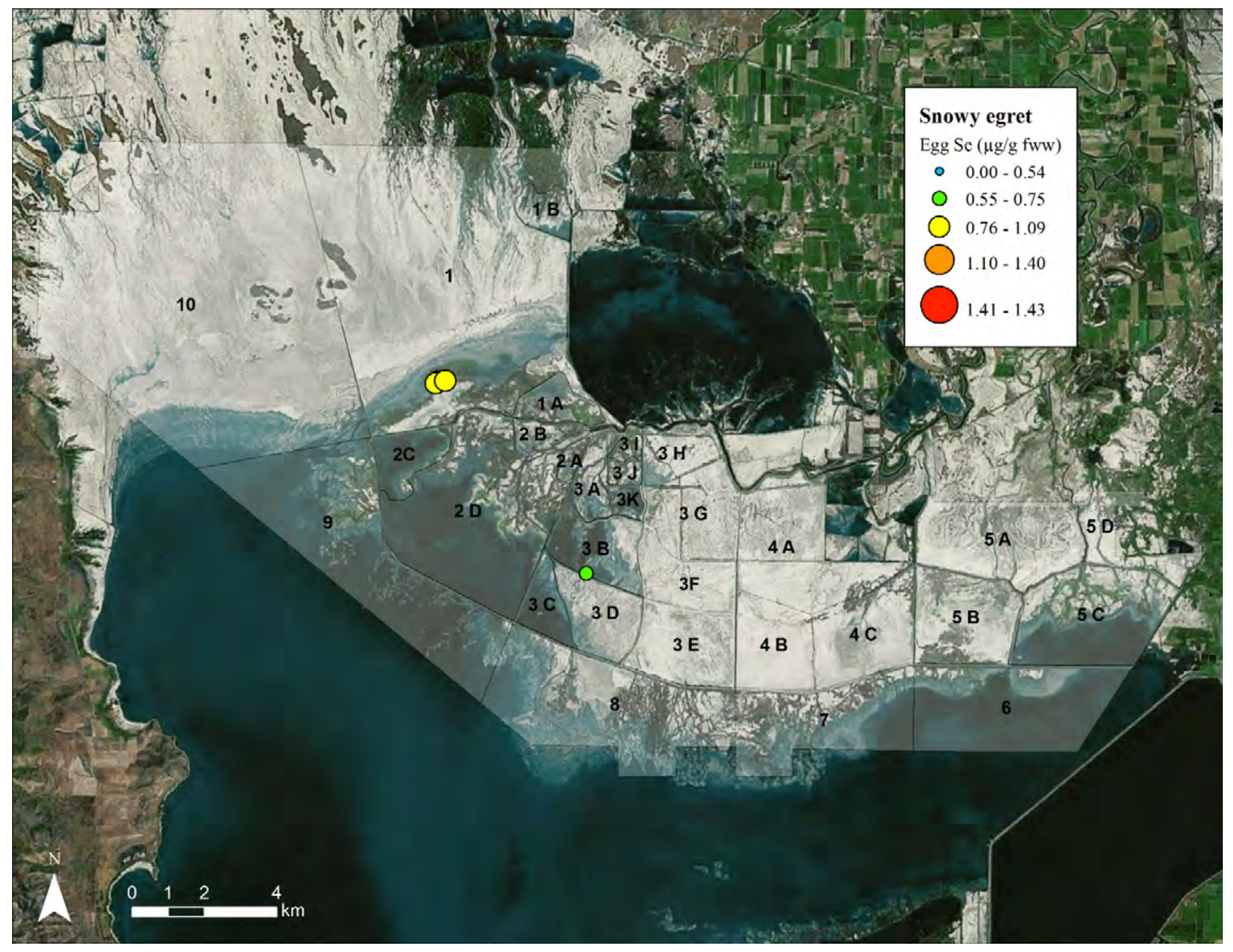

Figure C-30. Selenium concentrations (Se; $\mu \mathrm{g} / \mathrm{g}$ fww) in eggs of snowy egrets breeding at Bear River Migratory Bird Refuge in Great Salt Lake, Utah, $2010-2012$. 


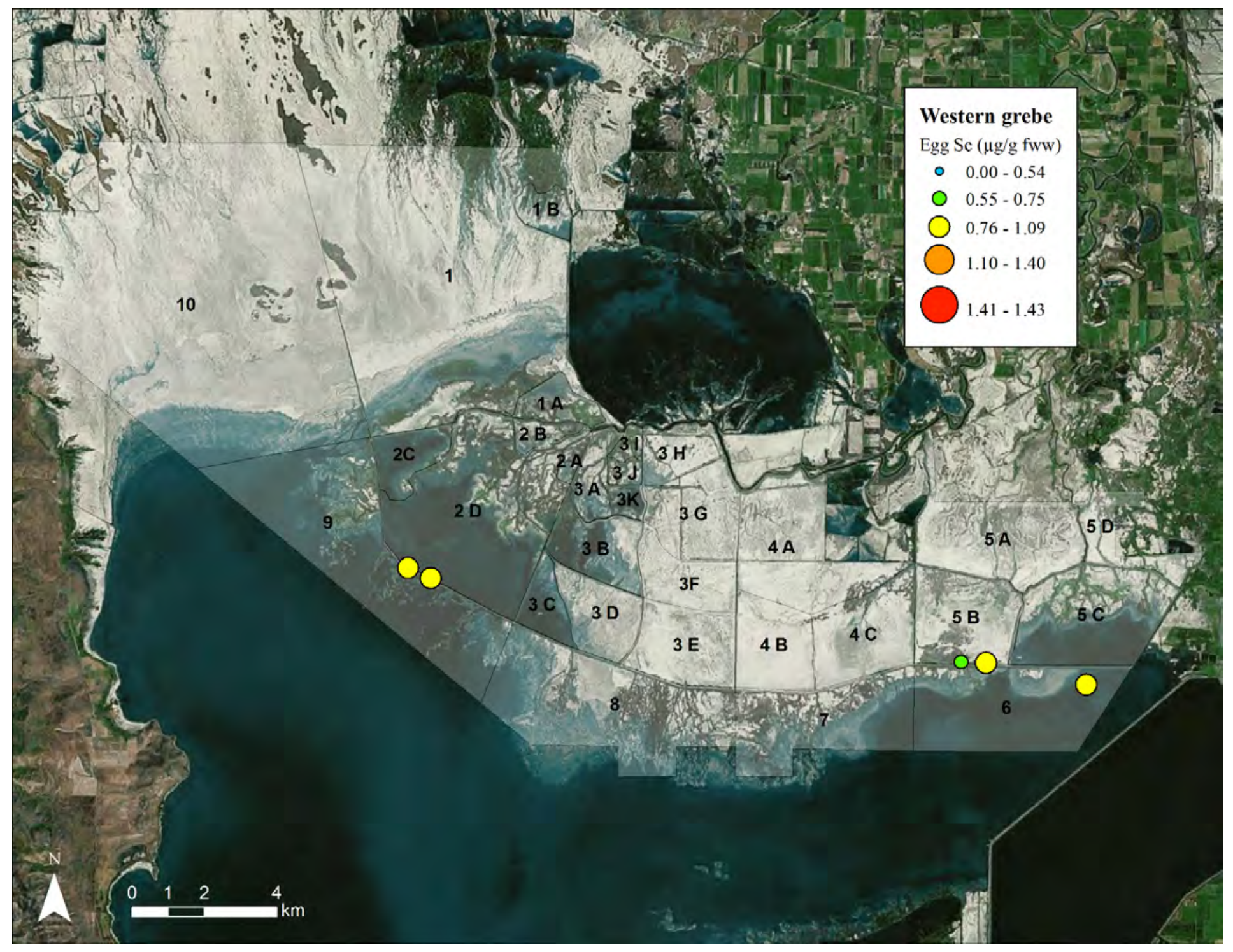

Figure C-31. Selenium concentrations (Se; $\mu \mathrm{g} / \mathrm{g} \mathrm{fww)} \mathrm{in} \mathrm{eggs} \mathrm{of} \mathrm{western} \mathrm{grebes} \mathrm{breeding} \mathrm{at} \mathrm{Bear} \mathrm{River} \mathrm{Migratory} \mathrm{Bird} \mathrm{Refuge} \mathrm{in} \mathrm{Great} \mathrm{Salt} \mathrm{Lake,} \mathrm{Utah,} \mathrm{2010-2012.}$ 


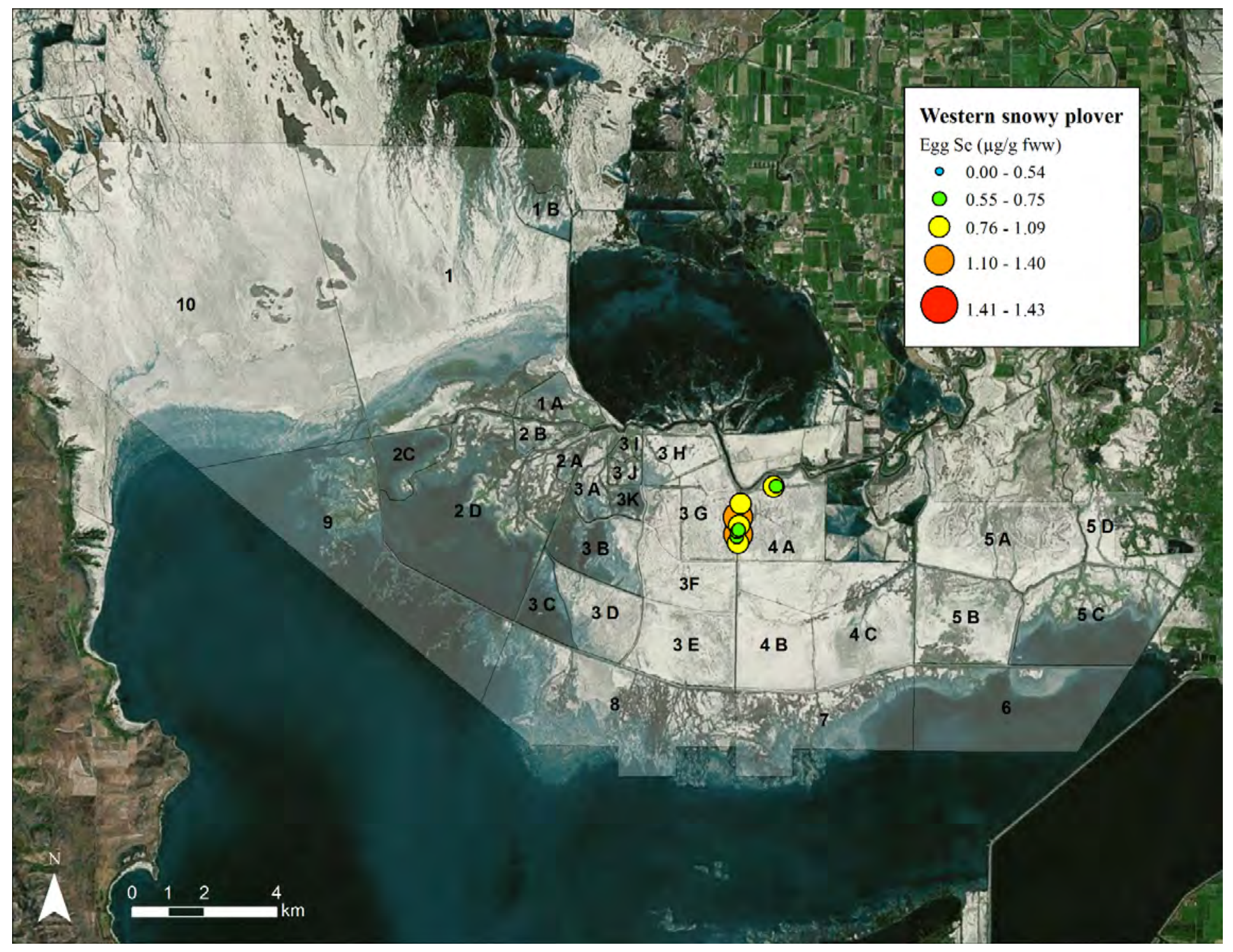

Figure C-32. Selenium concentrations (Se; $\mu \mathrm{g} / \mathrm{g}$ fww) in eggs of snowy plovers breeding at Bear River Migratory Bird Refuge in Great Salt Lake, Utah, $2010-2012$. 


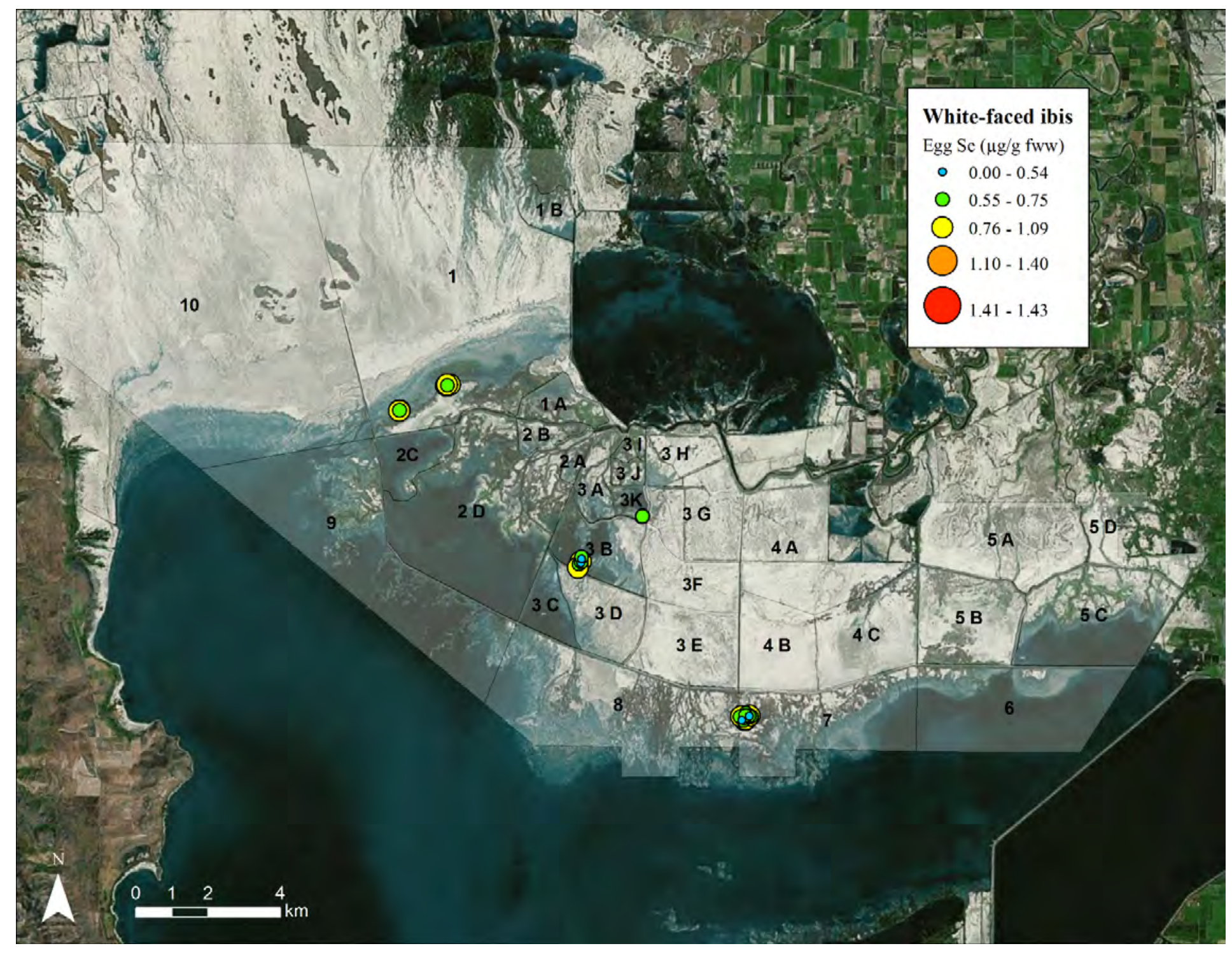

Figure C-33. Selenium concentrations (Se; $\mu \mathrm{g} / \mathrm{g}$ fww) in eggs of white-faced ibis breeding at Bear River Migratory Bird Refuge in Great Salt Lake, Utah, 2010-2012. 


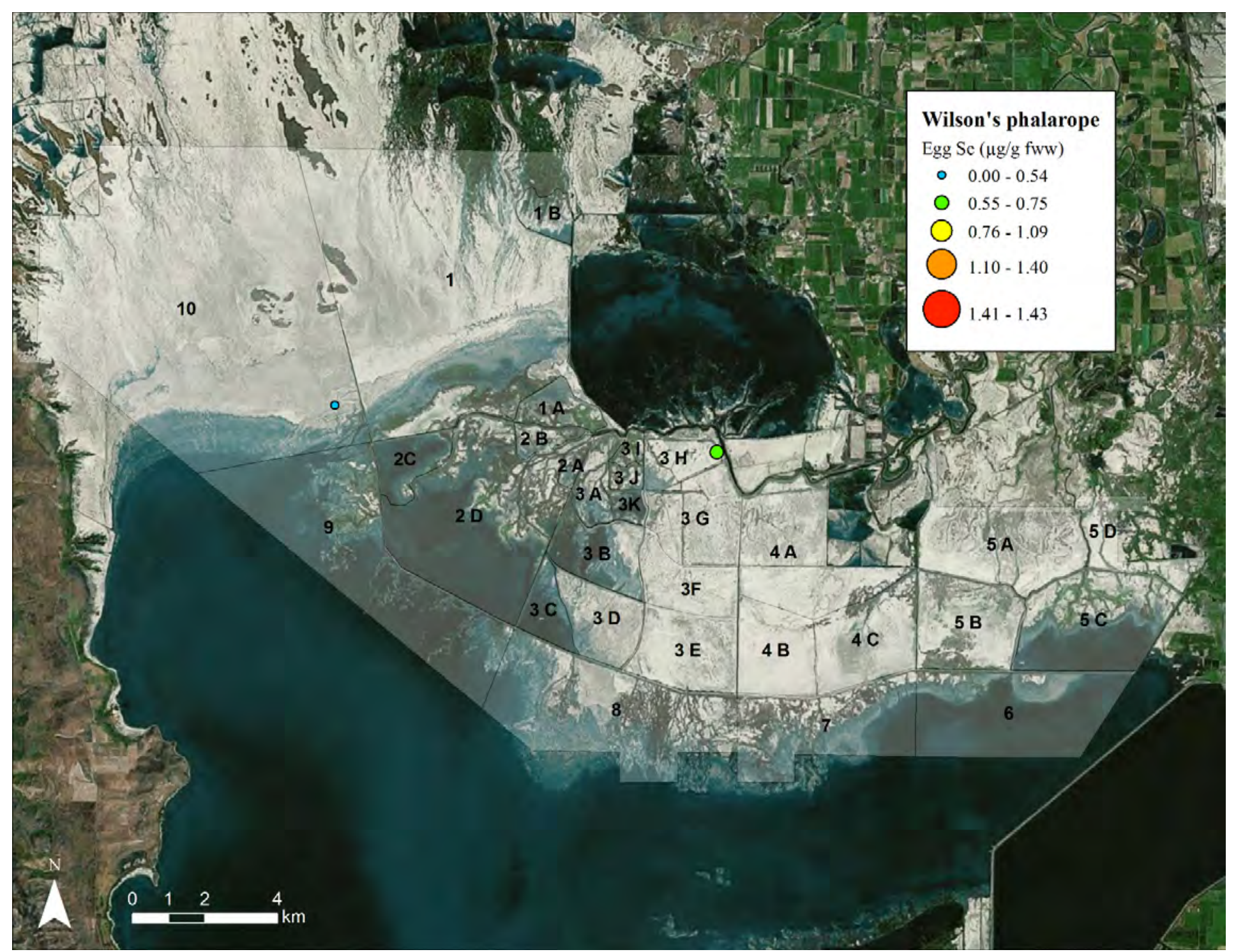

Figure C-34. Selenium concentrations (Se; $\mu \mathrm{g} / \mathrm{g}$ fww) in eggs of Wilson's Phalarope breeding at Bear River Migratory Bird Refuge in Great Salt Lake, Utah, $2010-2012$. 


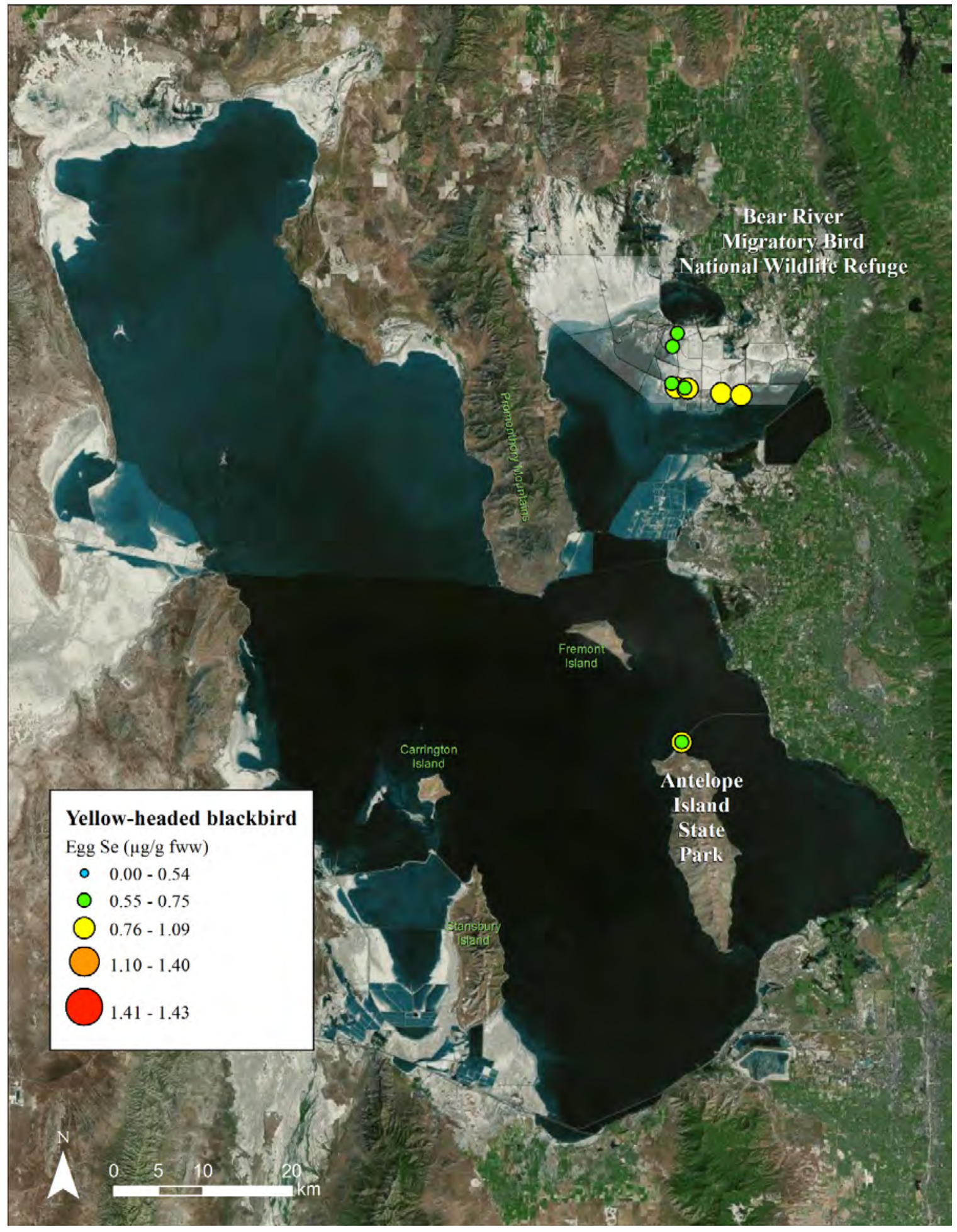

Figure C-35. Selenium concentrations (Se; $\mu \mathrm{g} / \mathrm{g}$ fww) in eggs of yellow-headed blackbirds breeding at Bear River Migratory Bird Refuge in Great Salt Lake, Utah, 2010-2012. 


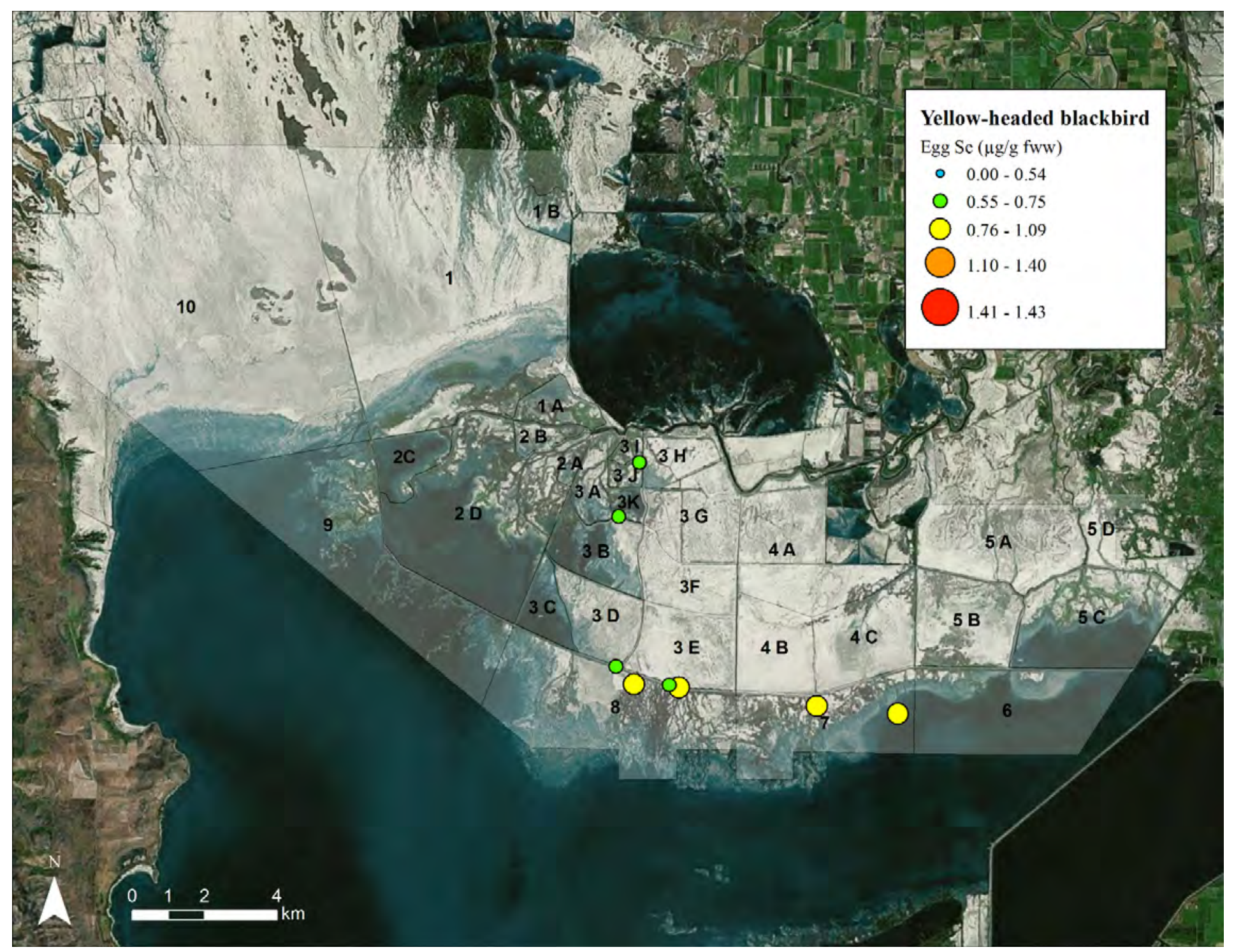

Figure C-36. Selenium concentrations (Se; $\mu \mathrm{g} / \mathrm{g}$ fww) in eggs of yellow-headed blackbirds breeding at Bear River Migratory Bird Refuge in Great Salt Lake, Utah, 2010-2012. 
This page left intentionally blank 
Publishing support provided by the U.S. Geological Survey

Science Publishing Network, Tacoma Publishing Service Center

For more information concerning the research in this report, contact the Director, Western Ecological Research Center

U.S. Geological Survey

3020 State University Drive East

Sacramento, California 95819

http://werc.usgs.gov/ 


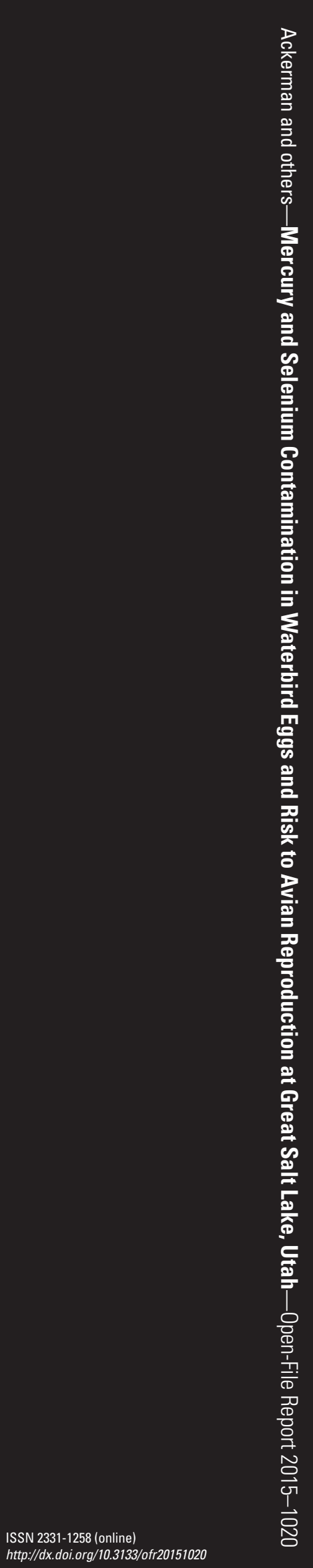

